UNIVERSIDADE DE SÃO PAULO

ESCOLA DE ENGENHARIA DE SÃO CARLOS

GUILHERME PEIXOTO

SISTEMA FERMENTATIVO DE DUAS FASES PARA A PRODUÇÃO DE HIDROGÊNIO E METANO A PARTIR DE ESGOTO SANITÁRIO COMBINADO COM ÁGUAS RESIDUÁRIAS INDUSTRIAIS

VERSÃO CORRIGIDA

São Carlos - SP

2011 


\title{
SISTEMA FERMENTATIVO DE DUAS FASES PARA A PRODUÇÃO DE HIDROGÊNIO E METANO A PARTIR DE ESGOTO SANITÁRIO COMBINADO COM ÁGUAS RESIDUÁRIAS INDUSTRIAIS
}

\author{
Tese apresentada à Escola de Engenharia de \\ São Carlos, da Universidade de São Paulo, \\ como parte dos requisitos necessários à \\ obtenção do título de Doutor em Ciências, \\ Programa de Hidráulica e Saneamento.
}

Orientador: Prof. Assoc. Marcelo Zaiat

\author{
VERSÃO CORRIGIDA \\ São Carlos - SP


AUTORIZO A REPRODUÇÃO TOTAL OU PARCIAL DESTE TRABALHO, POR QUALQUER MEIO ÇONVENCIONAL OU ELETRÔNICO, PARA FINS DE ESTUDO E PESQUISA, DESDE QUE CITADA A FONTE.

Peixoto, Guilherme
P379s Sistema ferment

Sistema fermentativo de duas fases para a produção de hidrogênio e metano a partir de esgoto sanitário combinado com águas residuárias industriais. / Guilherme Peixoto; orientador Marcelo Zaiat. São Carlos, 2012 .

Tese (Doutorado) - Programa de Pós-Graduação e Área de Concentração em Hidráulica e Saneamento -- Escola de Engenharia de São Carlos da Universidade de São Paulo, 2012 .

1. Fermentação anaeróbia. 2. Processo anaeróbio. 3. Hidrogênio. 4. Metano. 5. Esgoto sanitário. I. Título. 


\section{FOLHA DE JULGAMENTO}

Candidato: Engenheiro GUILHERME PEIXOTO

Título da tese: "Sistema fermentativo de duas fases para a produção de hidrogênio e metano a partir de esgoto sanitário".

Data da defesa: 29/11/2011:

Comissão Julgadora:

Resultado:

Oavis

Prфf. Associado Marcelo Zaiat (Orientador)

(Escola de, Engegharia de São Carlos/EESC)

quelson Silva

Prof. Dr. Edson Luiz Silva

(Universidade Federal de São Carlos/UFSCar)

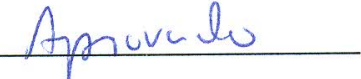

Wariun OR z Jamianic

Prof $^{a}$. Dr ${ }^{a}$. Márcia Helena Rissato Zamariolli Damianovic

APRONABO

(Escola de Engenharia de São Carlos/EESC)

Prof. Dr.Luiz Olinto Monteggia

(Universidadefederahdo Rio Grande do SUI/UFRGS)

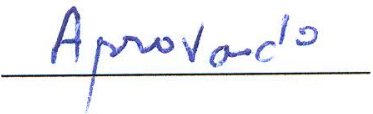

Prof. Dr. Marlei Bárbosø Passotto

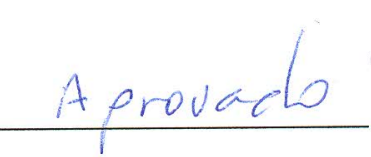

(Universidade Federal Triângulo Mineiro/UFTM)

Aporado

Coordenador do Programa de Pós-Graduação em Engenharia Hidráulica e Saneamento:

Prof. Titular Edson Cezar Wendland

Presidente da Comissão de Pós-Graduação:

Prof. Associado Paulo Cesar Lima Segantine 


\section{DEDICATÓRIA}

Aos meus pais, grandes mestres da vida.

Pelo amor, incentivo e dedicação. 


\section{AGRADECIMENTOS}

À minha família: meus pais, Luiz e Lourdes, e meu irmão Henrique, pelo carinho, suporte e confiança desde o início de minha caminhada.

À Andrea e Felipe, pela compreensão, suporte e estímulo.

Ao professor, orientador e companheiro, Marcelo Zaiat, pelos ensinamentos constantes, pela dedicação, confiança, apoio e pelo papel fundamental em minha escolha pela carreira acadêmica.

Aos professores do Programa de Pós-Graduação em Engenharia Hidráulica e Saneamento, em particular aos professores Marcelo Zaiat, Eugênio Foresti e Marcius Giorgetti.

Ao Departamento de Hidráulica e Saneamento da Escola de Engenharia de São Carlos da Universidade de São Paulo e demais professores da USP pela preocupação constante com o avanço tecnológico brasileiro e o ensino de qualidade.

À Janja, pelo auxílio freqüente nas análises cromatográficas.

À Eloísa e Débora pelas análises microbiológicas.

À Pavi, Sá e Rose, pelos serviços prestados durante o doutorado. 
À todos do Laboratório de Processos Biológicos, que conviveram e compartilharam comigo uma etapa da vida tão importante:

- Ao Guto, por ter me auxiliado em uma parte importante do meu trabalho.

- Ao Henrique, por ter colaborando muito com os assuntos referentes a Área de Pesquisa em Tratamento de Esgoto Sanitário (Casinha).

À todos os amigos que compartilharam comigo o doutorado, em especial aos engenheiros Gustavo Mockaitis, Jorge Pantoja, Antonio Pedro de Oliveira Netto e Theo Syrto Octavio de Souza.

À todos os professores que contribuíram para minha formação, desde a mais tenra infância.

À FAPESP, pela bolsa de doutorado concedida e financiamento do projeto.

Aos meus grandes companheiros e camaradas Mauro e William, amizades de toda uma vida.

Àqueles que deram condições para a realização desse trabalho, que sem dúvida é fruto da cooperação de todos. 


\section{RESUMO}

PEIXOTO, G. Sistema fermentativo de duas fases para a produção de hidrogênio e metano a partir de esgoto sanitário combinado com águas residuárias industriais. Tese (Doutorado) - Escola de Engenharia de São Carlos, Departamento de Hidráulica e Saneamento, Universidade de São Paulo, São Carlos, 2011.

A possibilidade da produção de hidrogênio a partir de esgoto sanitário com a posterior geração de metano a partir do efluente do processo acidogênico foi avaliada em reatores anaeróbios em batelada e contínuos. Nos reatores em batelada com biomassa acidogênica não houve produção de hidrogênio a partir de esgoto sanitário, o que motivou a avaliação de outros substratos. Hidrogênio foi produzido a partir de água residuária de parboilização de arroz (23,9 mL $\mathrm{H}_{2} \mathrm{~g}^{-1}$ DQO) e vinhaça (20,8 mL $\mathrm{H}_{2} \mathrm{~g}^{-1}$ DQO), enquanto nos reatores com biomassa metanogênica, metano foi produzido por esgoto sanitário (46,3 $\left.\mathrm{mL} \mathrm{CH}_{4} \mathrm{~g}^{-1} \mathrm{DQO}\right)$, glicerol (180,1 $\mathrm{mL} \mathrm{CH}_{4} \mathrm{~g}^{-1}$ DQO), água residuária de parboilização de arroz (115,5 $\left.\mathrm{mL} \mathrm{CH}_{4} \mathrm{~g}^{-1} \mathrm{DQO}\right)$ e vinhaça (255,4 $\mathrm{mL} \mathrm{CH}_{4} \mathrm{~g}^{-1}$ DQO). Ainda nos reatores em batelada, definiu-se que a diluição de vinhaça no esgoto sanitário mais adequada para a produção de hidrogênio deveria resultar numa mistura com DQO de aproximadamente $4 \mathrm{~g} \mathrm{~L}^{-1}$, sem que o rendimento de $\mathrm{H}_{2}$ decrescesse. A produção de hidrogênio a partir de esgoto sanitário nos reatores contínuos não foi possível sem a adição de fonte de carboidratos. Demonstrou-se que a concentração mínima de carboidratos, em termos de sacarose, seria de $0,9 \mathrm{~g} \mathrm{~L}^{-1}$. Nos reatores de leito estruturado com suporte de cerâmica e fluxo ascendente alimentados com 50\% de esgoto e 50\% de vinhaça, foram alcançados o maior período de produção de $\mathrm{H}_{2}$ e a maior fração do mesmo no biogás, correspondendo a 56 dias e 7,1\%, respectivamente. O reator UASB usando como substrato o efluente de reator acidogênico produziu metano com estabilidade até a COV de 0,91 g DQO $\mathrm{L}^{-1} \mathrm{~d}^{-1}$, porém se desestabilizou com a COV de 2,94 g DQO $\mathrm{L}^{-1} \mathrm{~d}^{-1}$.

Palavras chave: processo anaeróbio; hidrogênio; metano; esgoto sanitário; 


\begin{abstract}
PEIXOTO, G. Two phase fermentative process for hydrogen and methane production from domestic wastewater combined with industrial wastewaters. Thesis (Doctorate) - São Carlos School of Engineering, Department of Hydraulics and Sanitation, University of São Paulo, São Carlos, 2011.

The possibility of producing hydrogen from sewage with the subsequent generation of methane with the effluent of the acidogenic process was evaluated in batch and continuous anaerobic reactors. In batch reactors, with acidogenic biomass, there was no production of hydrogen from sewage, which led to the evaluation of other substrates. Hydrogen was produced from parboiled rice wastewater (23,9 mL H $\mathrm{g}^{-1}$ COD) and vinasse (20,8 $\left.\mathrm{mL} \mathrm{H}_{2} \mathrm{~g}^{-1} \mathrm{COD}\right)$, while in reactors with methanogenic biomass, methane was produced by sewage (46,3 $\left.\mathrm{mL} \mathrm{CH}_{4} \mathrm{~g}^{-1} \mathrm{COD}\right)$, glycerol (180,1 $\left.\mathrm{mL} \mathrm{CH}_{4} \mathrm{~g}^{-1} \mathrm{COD}\right)$ parboiled rice wastewater (115,5 $\mathrm{mL} \mathrm{CH}_{4} \mathrm{~g}^{-1} \mathrm{COD}$ ) and vinasse (255,4 $\left.\mathrm{mL} \mathrm{CH}_{4} \mathrm{~g}^{-1} \mathrm{COD}\right)$. In addition, in batch reactors, it was determined that vinasse dilution in sewage more suitable for hydrogen production should result in a mixture with approximately 4 g COD L ${ }^{-1}$ without decrease on hydrogen yield. The hydrogen production from sewage in continuous reactors could not be sustained without the addition of external carbohydrates source. It was demonstrated that the minimum concentration of carbohydrates, in terms of sucrose, would be $0,9 \mathrm{~g} \mathrm{~L}^{-1}$. In the upflow ceramic structured bed reactor fed with 50\% sewage and 50\% vinasse at the 8h HRT, it was achieved the longest $\mathrm{H}_{2}$ production period and the largest fraction of hydrogen in biogas, which corresponded to 56 days and 7,1\% respectively. The UASB reactor using the effluent of the acidogenic reactor as substrate, produced methane with stability at the OLR of $0,91 \mathrm{~g} \mathrm{COD} \mathrm{L}^{-1} \mathrm{~d}^{-1}$, but it collapsed with the OLR of 2,94 g COD L $\mathrm{g}^{-1} \mathrm{~d}^{-1}$.
\end{abstract}

Keywords: anaerobic process; hydrogen; methane; sewage; 


\section{LISTA DE FIGURAS}

Figura 3.1 Diagrama simplificado dos pontos de geração e consumo de hidrogênio no processo completo de digestão anaeróbia

Figura 4.1 Desenho esquemático dos reatores de leito fixo utilizados neste trabalho.

Figura 4.2 Desenho esquemático do reator de manta de lodo

Figura 4.3 Detalhe do material suporte empregado na confecção dos leitos fixos empacotados

Figura 4.4 Curva de distribuição granulométrica das aparas de polietileno 34

Figura 4.5 Fotografia dos cilindros de polietileno, espuma e cerâmica (da esquerda para a direita)

Figura 4.6 Representação da vista superior dos reatores com leito estruturado e da disposição dos suportes cilíndricos. As linhas finas denotam a distribuição eqüidistante dos suportes

Figura 4.7 Fluxograma das etapas envolvidas na fase experimental 55

Figura 4.8 Fluxograma do procedimento adotado na Etapa 1 56

Figura 4.9 Fluxograma do procedimento adotado na Etapa $2 \quad 59$

Figura 4.10 Fluxograma do procedimento adotado na Etapa $3 \quad 62$

Figura 4.11 Fluxograma do procedimento adotado na Etapa $4 \quad 64$

Figura 4.12 Arranjo de leito estruturado em coluna e intercalado 65

Figura 4.13 Fluxograma do procedimento adotado na Etapa 566

Figura 4.14 Fluxograma do procedimento adotado na Etapa $6 \quad 68$

Figura 4.15 Diagrama do funcionamento integrado dos reatores na Etapa $6 \quad 69$

Figura 5.1 Perfil temporal da DQO do esgoto afluente $\quad 72$

Figura 5.2 Perfil temporal do nitrogênio amoniacal do esgoto afluente 72

Figura 5.3 Perfil temporal do fosfato do esgoto afluente 73

$\begin{array}{lll}\text { Figura 5.4 Medidas de } \mathrm{pH} \text { realizadas no afluente e efluente do reator na } & 74\end{array}$ Etapa 1

Figura 5.5 Perfil temporal de alcalinidade (mg L $\left.{ }^{-1} \mathrm{CaCO}_{3}\right)$ e ácidos 75 voláteis (mg L ${ }^{-1} \mathrm{HAc}$ ) do reator na Etapa 1 
Figura 5.6 Concentração e porcentagem de degradação de carboidratos do reator na Etapa 1

Figura 5.7 Concentração e porcentagem de remoção de matéria orgânica medida como DQO no reator na Etapa 1

Figura 5.8 Composição do biogás do reator na Etapa 1 79

Figura 5.9 Leito empacotado com acúmulo de material intersticial na 80 Etapa 1

Figura 5.10 Vazões de trabalho dos reatores R1 e R2 na Etapa 2 81

Figura 5.11 Variação do pH afluente e efluente dos reatores R1 e R2 na Etapa 2

Figura 5.12 Concentrações de matéria orgânica afluente e efluente medidas como $\mathrm{mg} \mathrm{L}^{-1}$ de DQO nos reatores da Etapa 2

Figura 5.13 Concentração de carboidratos no afluente e efluente dos 85 reatores R1 e R2 na Etapa 2

Figura 5.14 Vazão volumétrica de hidrogênio e composição do biogás no 86 reator R1 (TDH 1h) na Etapa 2

Figura 5.15 Vazão volumétrica de hidrogênio e composição do biogás no reator R2 (TDH 2h) na Etapa 2

Figura 5.16 Concentração de ácidos orgânicos afluentes ao reator R1 na 88 Etapa 2

Figura 5.17 Concentração de ácidos orgânicos efluentes ao reator R1 na Etapa 2

Figura 5.18 Concentração de ácidos orgânicos afluentes ao reator R2 na Etapa 2

Figura 5.19 Concentração de ácidos orgânicos efluentes ao reator R2 na Etapa 2

Figura 5.20 Reatores anaeróbios de leito fixo constituído por empacotamento de aparas de polietileno utilizados na Etapa 2

Figura 5.21 Remoção da DQO dos reatores acidogênicos da Etapa 3; (...) decaimento exponencial de primeira ordem

Figura 5.22 Degradação de carboidratos nos reatores acidogênicos da 94 Etapa 3; (...) decaimento exponencial de primeira ordem 
Figura 5.23 Produção de hidrogênio pelos substratos avaliados na Etapa 3;

(...) equação de Gompertz modificada

Figura 5.24 Metabólitos solúveis produzidos pelo reator com esgoto na Etapa 3

Figura 5.25 Metabólitos solúveis produzidos pelo reator com glicerol na Etapa 3

Figura 5.26 Metabólitos solúveis produzidos pelo reator com água 100 residuária de parboilização de arroz na Etapa 3

Figura 5.27 Metabólitos solúveis produzidos pelo reator com vinhaça na Etapa 3

Figura 5.28 Metabólitos solúveis produzidos pelo reator com sacarose na Etapa 3

Figura 5.29 Remoção da DQO dos reatores metanogênicos da Etapa 3; (...) decaimento exponencial de primeira ordem

Figura 5.30 Degradação de carboidratos nos reatores metanogênicos da Etapa 3

Figura 5.31 Produção de metano a partir dos metabólitos solúveis da produção de hidrogênio; (...) modelo cinético de primeira ordem

Figura 5.32 Metabólitos solúveis do reator usando esgoto acidificado na Etapa 3

Figura 5.33 Metabólitos solúveis do reator usando glicerol acidificado na Etapa 3

Figura 5.34 Metabólitos solúveis do reator usando água residuária de parboilização de arroz acidificada na Etapa 3

Figura 5.35 Metabólitos solúveis do reator usando vinhaça acidificada na Etapa 3

Figura 5.36 Metabólitos solúveis do reator usando sacarose acidificada na Etapa 3

Figura 5.37 Volume de $\mathrm{H}_{2}$ e $\mathrm{CO}_{2}$ produzidos em 5 diferentes diluições de vinhaça em água deionizada na Etapa 4

Figura 5.38 Rendimento na produção de $\mathrm{H}_{2}$ e proporção de gases gerados 
para cada diluição de vinhaça em água deionizada na Etapa 4

Figura 5.39 Volume de $\mathrm{H}_{2}$ e $\mathrm{CO}_{2}$ produzidos em 5 diferentes diluições de vinhaça em esgoto sanitário na Etapa 4

Figura 5.40 Rendimento na produção de $\mathrm{H}_{2}$ e proporção de gases gerados para cada diluição de vinhaça em esgoto sanitário na Etapa 4

Figura 5.41 Curvas C para cada material suporte submetido às duas configurações de leito avaliados na Etapa 5

Figura 5.42 Vazão de biogás no reator de polietileno com TDH de 2h (Etapa 5)

Figura 5.43 Composição do biogás no reator operado com leito de polietileno no TDH de 2h (Etapa 5)

Figura 5.44 Vazão de biogás no reator de polietileno com TDH de $8 \mathrm{~h}$ (Etapa 5)

Figura 5.45 Composição do biogás no reator de polietileno com TDH de 8h (Etapa 5)

Figura 5.46 Vazão de biogás no reator de espuma com TDH de 2h (Etapa 5)

Figura 5.47 Composição do biogás no reator de espuma com TDH de 2h (Etapa 5)

Figura 5.48 Vazão de biogás no reator de espuma com TDH de 8h (Etapa 5)

Figura 5.49 Composição do biogás no reator de espuma com TDH de 8h (Etapa 5)

Figura 5.50 Microscopia ótica da biomassa retirada do suporte de espuma de poliuretano (Etapa 5)

Figura 5.51 Microscopia ótica com fluorescência da biomassa retirada do suporte de espuma de poliuretano (Etapa 5)

Figura 5.52 Vazão de biogás no reator de cerâmica com TDH de 2h (Etapa 5)

Figura 5.53 Composição do biogás no reator de cerâmica com TDH de 2h (Etapa 5)

Figura 5.54 Vazão de biogás no reator de cerâmica com TDH de 8h (Etapa 
5)

Figura 5.55 Microscopia ótica do afluente aos reatores usados na Etapa $5 \quad 146$

Figura 5.56 Microscopia ótica do efluente aos reatores usados na Etapa 5147

Figura 5.57 Composição do biogás no reator de cerâmica com TDH de 8h 148 (Etapa 5)

Figura 5.58 Leito estruturado com polietileno de baixa densidade ao final da operação (Etapa 5)

Figura 5.59 Leito estruturado com espuma de poliuretano ao final da 150 operação (Etapa 5)

Figura 5.60 Leito estruturado com cerâmica ao final da operação (Etapa 5)

Figura 5.61 Eficiência de remoção de matéria orgânica pelo reator UASB alimentado com esgoto sanitário (Etapa 6)

Figura 5.62 Vazão de biogás no reator UASB alimentado com esgoto sanitário (Etapa 6)

Figura 5.63 Composição do biogás do reator UASB tratando esgoto sanitário (Etapa 6)

Figura 5.64 Vazão de biogás no reator acidogênico alimentado com meio sintético (Etapa 6)

Figura 5.65 Vazão de biogás no reator acidogênico após início da alimentação com esgoto e vinhaça (Etapa 6)

Figura 5.66 Composição do biogás do reator acidogênico alimentado com solução de sacarose (Etapa 6)

Figura 5.67 Composição do biogás do reator acidogênico alimentado com esgoto sanitário e vinhaça (Etapa 6)

Figura 5.68 Reatores metanogênico e acidogênico (esquerda para direita) acondicionados na câmara termostática para o início do funcionamento seqüencial na Etapa 6

Figura 5.69 Vazão de biogás no reator metanogênico integrado (Etapa 6)

Figura 5.70 Perfil de carga orgânica volumétrica aplicada ao reator UASB integrado (Etapa 6)

Figura 5.71 Composição do biogás gerado no reator metanogênico integrado (Etapa 6) 
Figura 5.72 Eficiência de remoção de matéria orgânica no reator UASB 163 integrado (Etapa 6)

Figura 5.73 Perfil temporal dos ácidos orgânicos efluentes do reator 164 UASB integrado (Etapa 6) 


\section{LISTA DE TABELAS}

Tabela 4.1 Dimensões dos reatores nas configurações A e B 30

Tabela 4.2 Dimensões do reator de manta de lodo 32

Tabela 4.3 Bombas utilizadas e função no sistema de alimentação 32

Tabela 4.4 Caracterização das aparas de polietileno de baixa densidade 34

Tabela 4.5 Características físicas dos cilindros de polietileno, espuma e 37 cerâmica

Tabela 4.6 Caracterização do esgoto sanitário, dos efluentes industriais e do substrato controle

Tabela 4.7 Composição do meio utilizado nos ensaios em reatores em batelada

Tabela 4.8 Parâmetros de controle e variáveis monitoradas na Etapa $1 \quad 57$

Tabela 4.9 Parâmetros de controle e variáveis monitoradas na Etapa $2 \quad 60$

Tabela 4.10 Parâmetros de controle e variáveis monitoradas na Etapa 362

Tabela 4.11 Parâmetros de controle e variáveis monitoradas na Etapa $4 \quad 64$

Tabela 4.12 Parâmetros de controle e variáveis monitoradas na Etapa 5

Tabela 4.13 Parâmetros de controle e variáveis monitoradas na Etapa $6 \quad 70$

Tabela 5.1 Cinética de primeira ordem para remoção de DQO e 93 carboidratos, e valores dos parâmetros da equação modificada de Gompertz para os substratos avaliados no estágio acidogênico (Etapa 3)

Tabela 5.2 Balanço de massa (em termos de DQO) para os resultados obtidos na etapa acidogênica dos substratos avaliados (Etapa 3)

Tabela 5.3 Cinética de primeira ordem para remoção de DQO e valores dos parâmetros cinéticos obtidos com o modelo de primeira ordem para a produção de metano (Etapa 3)

Tabela 5.4 Balanço de massa (em termos de DQO) para os resultados obtidos na etapa metanogênica dos substratos avaliados (Etapa 3) 
Tabela 5.5 Caracterização da vinhaça utilizada nesta e nas Etapas 3, 5 e 6

Tabela 5.6 Aspectos operacionais do monitoramento dos reatores em batelada (Etapa 4)

Tabela 5.7 Características do escoamento com diferentes materiais suporte e configurações de leito avaliados na Etapa 5

Tabela 5.8 Descrição do substrato e cargas orgânicas volumétricas utilizadas em cada período de operação do reator UASB na Etapa 6 


\section{ABREVIATURAS}

$\begin{array}{ll}\text { CO } & \text { carga orgânica } \\ \text { CO aplic. } & \text { carga orgânica aplicada } \\ \text { COV } & \text { carga orgânica volumétrica } \\ \text { DQO } & \text { demanda química de oxigênio } \\ \text { PMS } & \text { produtos metabólicos solúveis } \\ \text { pH } & \text { potencial hidrogeniônico } \\ \text { ST } & \text { sólidos totais } \\ \text { SF } & \text { sólidos fixos } \\ \text { SV } & \text { sólidos voláteis } \\ \text { SST } & \text { sólidos em suspensão totais } \\ \text { SSV } & \text { sólidos em suspensão voláteis } \\ \text { TDH } & \text { tempo de detenção hidráulica } \\ \text { UASB } & \text { upflow anaerobic sludge blanket reactor }\end{array}$




\section{SÍMBOLOS}

C/N razão Carbono/Nitrogênio

$\mathrm{C} / \mathrm{P}$ razão Carbono/Fósforo

S/X razão Substrato/Biomassa

Q vazão de bombeamento de líquido $\left(\mathrm{L} \mathrm{min}^{-1}\right)$

$\varepsilon \quad$ porosidade do leito (\%)

$\mu_{\text {máx }}$ velocidade máxima específica de crescimento $\left(\mathrm{h}^{-1}\right)$

P potencial de produção de hidrogênio $(\mathrm{mL})$

$\mathrm{R}_{\mathrm{m}} \quad$ velocidade de produção de hidrogênio $\left(\mathrm{mL} \mathrm{h}^{-1}\right)$

$\lambda \quad$ tempo da fase lag (h)

$\mathrm{H}$ produção acumulada de hidrogênio (mL)

$\mathrm{Y}_{\mathrm{H} 2}$ rendimento na produção de $\mathrm{H}_{2}\left(\mathrm{~mL} \mathrm{H}_{2} \mathrm{~g}^{-1} \mathrm{DQO}\right)$

$\mathrm{R}_{\mathrm{s}} \quad$ velocidade específica de produção de hidrogênio ( $\mathrm{mL} \mathrm{H}_{2} \mathrm{~g}^{-1} \mathrm{~h}^{-1} \mathrm{~g}^{-1} \mathrm{SSV}$ )

$\mathrm{G} \quad$ produção acumulada de metano $(\mathrm{mL})$

$\mathrm{G}_{\mathrm{m}} \quad$ volume máximo acumulado de metano em um determinado tempo (mL)

$\mathrm{K}_{\mathrm{G}} \quad$ constante cinética aparente de produção de metano $\left(\mathrm{h}^{-1}\right)$

X concentração de biomassa (g SSV L ${ }^{-1}$ )

$\mathrm{Y}_{\mathrm{CH} 4}$ rendimento na produção de metano ( $\left.\mathrm{mL} \mathrm{CH}_{4} \mathrm{~g}^{-1} \mathrm{DQO}\right)$

$\mathrm{C}_{\mathrm{DQO}}$ concentração de matéria orgânica (mg L $\left.{ }^{-1} \mathrm{DQO}\right)$

$\mathrm{C}_{\mathrm{C}}$ concentração de carboidratos $\left(\mathrm{mg} \mathrm{L}^{-1}\right)$

$\mathrm{k}_{1} \quad$ constante cinética aparente de degradação de matéria orgânica $\left(\mathrm{h}^{-1}\right)$

$\mathrm{k}_{2} \quad$ constante cinética aparente de degradação de carboidratos $\left(\mathrm{h}^{-1}\right)$

$\mathrm{k}_{2}$ ' constante cinética aparente de degradação de matéria orgânica $\left(\mathrm{h}^{-1}\right)$

C concentração do traçador

$\theta \quad$ tempo de detenção hidráulica

Oh tempo de detenção hidráulica médio

$\sigma^{2} \quad$ variância

$D / \mu . L$ número de dispersão 


\section{SUMÁRIO}

RESUMO

ABSTRACT

LISTA DE FIGURAS iii

LISTA DE TABELAS ix

LISTA DE ABREVIATURAS Xi

LISTA DE SÍMBOLOS Xii

1. INTRODUÇÃO 1

2. OBJETIVOS 5

3. REVISÃO BIBLIOGRÁFICA 7

3.1. Panorama Energético, Ambiental e a Possibilidade de Recuperação 7 de Energia de Águas Residuárias

3.2. Produção Biológica de Hidrogênio 9

3.2.1. Produção biológica via fermentação 10

3.2.1.1. Bactérias fermentativas 10

3.3. Produção de Hidrogênio em Reatores Anaeróbios 11

3.3.1. Influência do tempo de detenção hidráulica 13

3.3.2. Influência do material suporte 14

3.3.3. Importância do $\mathrm{pH} \quad 16$

3.3.4. Efeito da temperatura 16

3.3.5. Efeito do inóculo 17

3.3.6. Características do substrato 18

3.3.6.1. Influência das razões $\mathrm{C} / \mathrm{N}$ e C/P 20

3.3.6.2. Influência da razão S/X 23

3.3.7. Reatores de leito fixo 24

3.3.8. Operação de um sistema fermentativo de dois estágios destinado a 25 produção de hidrogênio e metano

3.3.9. 3.3.9 - Considerações Finais 28

4. MATERIAL E MÉTODOS 29 
$\begin{array}{llr}\text { 4.1. } & \text { Reatores }\end{array}$

4.1.1. Reatores contínuos 29

4.1.1.1. Material suporte 32

4.1.2. Reatores em batelada 38

4.2. Substrato 38

4.2.1. Esgoto sanitário 38

4.2.2. Águas residuárias 39

4.3. Inóculos 40

4.4. Métodos Analíticos 41

4.5. Medição da vazão volumétrica do biogás 48

4.6. Estudos hidrodinâmicos nos reatores de leito fixo com diferentes 48 arranjos e materiais suporte

4.7. Estudos cinéticos nos reatores em batelada com diferentes substratos 51

4.8. Exames Microbiológicos 53

4.8.1. Microscopia 53

4.9. Procedimento Experimental 54

4.9.1. Etapa $1 \quad 56$

4.9.2. Etapa $2 \quad 57$

4.9.3. Etapa $3 \quad 60$

4.9.4. Etapa $4 \quad 63$

4.9.5. Etapa $5 \quad 65$

$\begin{array}{lll}\text { 4.9.6. } & \text { Etapa } 6 & 67\end{array}$

5. RESULTADOS E DISCUSSÃO 71

5.1. $\quad$ Etapa 1 - Avaliação do efeito do TDH sobre a produção de $\mathrm{H}_{2}$ a

a partir de esgoto sanitário por um reator anaeróbio de fluxo ascendente com leito empacotado com aparas de polietileno

5.2. Etapa 2 - Avaliação do efeito da suplementação com carboidratos 80 sobre a produção de $\mathrm{H}_{2}$ a partir de esgoto sanitário por reatores anaeróbios de fluxo ascendente com leito empacotado com aparas de polietileno

5.3. $\quad$ Etapa 3 - Reatores em batelada para a produção de $\mathrm{H}_{2}$ e $\mathrm{CH}_{4}$ a 
partir de esgoto sanitário, glicerol, vinhaça, água residuária de parboilização de arroz e sacarose

5.3.1. Potencial de produção de hidrogênio a partir de águas residuárias 92

5.3.2. Potencial de produção de metano a partir dos produtos solúveis 109 gerados na produção de hidrogênio

5.4. Etapa 4 - Ensaios em batelada para a determinação da diluição de vinhaça em esgoto sanitário

5.5. Etapa 5 - Avaliação da influência de diferentes materiais suporte sobre a produção de hidrogênio em reatores anaeróbios de leito fixo estruturado e fluxo ascendente

5.5.1. Produção de hidrogênio a partir de esgoto sanitário suplementado com vinhaça por reatores anaeróbios de fluxo ascendente com leito estruturado com suportes de polietileno

5.5.2. Produção de hidrogênio a partir de esgoto sanitário suplementado com vinhaça em reatores anaeróbios de fluxo ascendente com leito estruturado com suportes de espuma de poliuretano

5.5.3. Produção de hidrogênio a partir de esgoto sanitário suplementado com vinhaça por reatores anaeróbios de fluxo ascendente com leito estruturado com suportes de cerâmica

5.6. Etapa 6 - Produção sequencial de hidrogênio e metano em um reator anaeróbio de leito estruturado com suportes de cerâmica e fluxo ascendente seguido por um reator anaeróbio de manta de lodo e fluxo ascendente (UASB)

6. CONCLUSÕES

7. SUGESTÕES

8. REFERÊNCIAS BIBLIOGRÁFICAS 


\section{CAPÍTULO 1}

\section{INTRODUÇÃO}

Previsões para o ano 2030 feitas pela Agência Internacional de Energia (IEA, 2006) indicam que os combustíveis fósseis irão permanecer como a principal fonte global de energia, sendo responsáveis por suprir os $83 \%$ do aumento de demanda entre 2004 e 2030. Dessa forma, a busca por fontes alternativas de energia têm sido pauta permanente na agenda mundial nos últimos anos, pois diante do cenário projetado pela IEA, há urgência em minimizar e controlar os impactos ambientais gerados com o uso de combustíveis fósseis.

Em meio às alternativas energéticas não-poluentes, o hidrogênio é considerado um carreador de energia altamente eficiente, com densidade energética de aproximadamente $122 \mathrm{~kJ} \mathrm{~g}^{-1}$, o que corresponde a cerca de 2,75 vezes mais que a energia obtida com a queima do petróleo (Lay et al., 1999).

A geração de hidrogênio por eletrólise consome de 4,5 a $5 \mathrm{~kW} \mathrm{~h}^{-1} \mathrm{~m}^{-3} \mathrm{H}_{2}$ produzido em eletrolisadores industriais de alta eficiência (Stojic et al., 2003), e elevadas quantidades de energia são necessárias para gerar temperaturas de 970 a $1100 \mathrm{~K}$ e pressões acima de 3,5 MPa para realizar a reforma a vapor do metano (Kothari et al., 2008), o que incentiva as pesquisas em produção biológica de hidrogênio, uma vez que o balanço energético do processo biológico encontra-se ainda em fase de estudo.

Com o intuito de reduzir o aporte de energia necessário para a produção de hidrogênio, os processos anaeróbios apresentam uma forma alternativa de gerá-lo 
além da reforma a vapor do metano e da eletrólise, que são atualmente os processos mais usados para a produção desse gás (IEA, 2007).

O processo de digestão anaeróbia envolve dois grupos principais de consórcios de microrganismos: as bactérias acidogênicas, que decompõem os substratos principalmente em $\mathrm{H}_{2}$, ácido acético e $\mathrm{CO}_{2}$; e as arquéias metanogênicas, que convertem o ácido acético, $\mathrm{H}_{2}$ e $\mathrm{CO}_{2}$ em gás metano (Cooney et al., 2007).

Neste estudo estes grandes grupos de microrganismos foram separados de modo a permitir a extração de hidrogênio em um primeiro estágio e metano em um segundo estágio, conforme é relatado nos estudos de outros autores como Giordano et al. (2011), Wang et al. (2011) e Xie et al. (2008).

O aspecto atrativo da produção biológica de hidrogênio é a possibilidade de utilização de efluentes ricos em matéria orgânica como substrato para o processo, porém o principal problema relativo ao potencial poluidor dos efluentes não é resolvido no estágio de produção de hidrogênio, uma vez que a remoção de matéria orgânica é muito baixa durante o processo (Van Ginkel et al., 2005). Por outro lado, a geração de metano envolve necessariamente remoções significativas de matéria orgânica porque os ácidos e outros produtos remanescentes gerados durante a produção de hidrogênio constituem os principais substratos para a produção desse gás.

Dessa forma, um processo de produção seqüencial torna-se interessante, pois a produção de hidrogênio e metano poderá ocorrer acoplada com a redução do potencial poluidor da água residuária utilizada.

No aspecto econômico, os efluentes domésticos e industriais constituem matérias-primas que não envolvem custos na sua produção e a sustentabilidade do 
processo biológico aplicado a geração de hidrogênio a partir de efluentes pode se tornar ainda maior por meio da combinação da fermentação com a produção de subprodutos de alto valor agregado como biopolímeros, por exemplo. (Hawkes et al., 2002).

No processo de produção biológica de hidrogênio, as águas residuárias tanto de origem doméstica quanto industrial passam a constituir uma potencial fonte energética prontamente encontrada em qualquer comunidade. Dessa forma, a geração de hidrogênio pode custar menos e ser conduzida usando matérias-primas locais, reduzindo os custos envolvidos no transporte e armazenamento.

De acordo com o censo nacional sobre esgotamento sanitário realizado em 2000 pelo IBGE (Instituto Brasileiro para Geografia e Estatística), regiões metropolitanas como Brasília-DF, São Paulo-SP e Rio de Janeiro-RJ, coletam 276.838, 1.295.058 e 1.447.631 $\mathrm{m}^{3} \mathrm{dia}^{-1}$ de esgoto, respectivamente.

Essa ampla disponibilidade de água residuária é encontrada não apenas com efluentes domésticos, mas com efluentes industriais, nos quais as concentrações de matéria orgânica são muito superiores, o que os faz merecer destaque como possíveis fontes de matéria prima para a produção de hidrogênio seguida da geração de metano.

Com a expansão da produção de combustíveis renováveis, como o biodiesel e o etanol, atualmente no Brasil a geração de glicerol, subproduto da produção de biodiesel, alcança 17,6 milhões de litros por ano, de acordo com o estudo realizado por Da Silva et al. (2009). Já a geração de vinhaça, principal subproduto da produção de etanol, atingiu 224 milhões de metros cúbicos na safra de 2008-2009, segundo os dados reportados pela UNICA (União das Indústrias de Cana-de-açúcar do Estado de 
São Paulo), o que motiva a avaliação de usos potenciais para esses resíduos, dentre eles a produção de hidrogênio e metano.

Na indústria alimentícia, efluentes como a água residuária de parboilização de arroz também apresentam grande disponibilidade. Pesquisas realizadas em 2005 pela EPAGRI (Empresa de Pesquisa Agropecuária e Extensão Rural de Santa Catarina) mostraram que na parboilização de $1 \mathrm{~kg}$ de arroz, cerca de 1 litro de efluente é produzido. Dessa forma, assumindo que $24 \%$ do arroz produzido no país é parboilizado (Amato, 2002), aproximadamente 2,8 milhões de metros cúbicos de água residuária de parboilização de arroz foram gerados em 2008, propiciando, dessa maneira, elevados estoques de fonte de carbono orgânico para o processo biológico de produção de hidrogênio e metano.

Considerando a ampla disponibilidade de águas residuárias, principalmente do esgoto sanitário e a crescente necessidade de fontes de energia sustentáveis, este estudo explorou as possibilidades de recuperação de energia na forma de hidrogênio e metano em sistemas sequenciais, nos quais o processo de digestão anaeróbia é dividido em uma etapa acidogênica e uma etapa metanogênica posterior por meio da separação física de consórcios microbianos em meios de reação distintos. 


\section{CAPÍTULO 2}

\section{OBJETIVOS}

\subsection{Objetivo geral}

O principal objetivo deste trabalho foi avaliar a produção de hidrogênio em reator acidogênico a partir de esgoto sanitário combinado com águas residuárias industriais seguida pela geração de metano em reator metanogênico a partir do efluente acidificado do primeiro reator.

\subsection{Objetivos específicos}

Os objetivos específicos desse projeto foram:

- Avaliar a produção de hidrogênio em reatores anaeróbios de leito empacotado e fluxo ascendente a partir de esgoto sanitário;

- Avaliar a utilização de diferentes efluentes como fonte complementar de substrato para o esgoto sanitário na produção de hidrogênio e metano;

- Avaliar a produção de hidrogênio em reatores anaeróbios de leito estruturado com diferentes materiais suporte a partir de esgoto sanitário suplementado;

- Avaliar o sistema composto por um reator anaeróbio de leito estruturado para a produção de hidrogênio a partir de esgoto sanitário suplementado e um 
reator anaeróbio de manta de lodo e fluxo ascendente (UASB) na produção de metano a partir do efluente acidificado no primeiro reator; 


\section{CAPÍTULO 3}

\section{REVISÃO BIBLIOGRÁFICA}

Neste capítulo serão abordados os fundamentos teóricos usados para a realização deste trabalho de pesquisa.

Na organização do capítulo, primeiramente, serão destacadas a importância do hidrogênio como uma forma de energia alternativa não-poluente e a obtenção do gás por via biológica. Depois, será descrita a principal forma de produção biológica de hidrogênio. A seguir, apontam-se as condições de processo necessárias para a produção biológica de hidrogênio via fermentação. Por último, são apresentados alguns trabalhos nos quais há a separação de fases para a produção de hidrogênio e metano.

\section{1 - Panorama Energético, Ambiental e a Possibilidade de Recuperação de Energia de Águas Residuárias}

Diante das previsões realizadas pela Agência Internacional de Energia (IEA, 2006) sobre o constante aumento da demanda energética mundial pode se inferir que, em um futuro próximo, o aquecimento global e a escassez de recursos energéticos fósseis se agravarão se outras fontes e formas de geração de energia não forem aplicadas. Essas duas questões interligadas encontram solução na utilização de fontes renováveis de energia. 
O hidrogênio têm sido considerado uma alternativa limpa quando deriva de matéria-prima renovável. É também bastante eficiente e não-agressivo ao meio ambiente, uma vez que apresenta densidade energética maior que a dos hidrocarbonetos e a sua combustão resulta em água como único produto final (Das e Veziroglu, 2001).

Geralmente, são quatro os processos básicos para a produção do gás hidrogênio a partir de fontes primárias de energia não-fósseis: (i) eletrólise da água; (ii) processos termoquímicos; (iii) processos radiolíticos e (iv) processos biológicos (Lay et al., 1998).

A obtenção de hidrogênio por via biológica pode ocorrer por meio de dois processos: fotossintético e processo fermentativo, sendo que a fermentação é tecnicamente mais simples e também apresenta como vantagens altas velocidades de produção de hidrogênio, um catalisador (hidrogenase) que não requer suprimento direto de ATP, a possibilidade de integração com os sistemas de disposição de resíduos orgânicos e os baixos custos da tecnologia anaeróbia (Hawkes et al., 2002).

De acordo com Mizuno et al. (2000), o hidrogênio obtido por processos biológicos a partir de águas residuárias apresenta-se como uma solução no âmbito energético, ambiental e econômico, uma vez que a aplicação em célula a combustível gera energia elétrica, tendo como produtos finais somente calor e água.

No aspecto econômico, as águas residuárias, particularmente os esgotos sanitários, constituem matérias-primas que não envolvem custos para serem adquiridas e apresentam ampla disponibilidade para alimentar processos de geração de hidrogênio.

Nesse mesmo contexto de geração biológica de energia a partir de águas 
residuárias, pode se destacar o gás metano produzido por reatores anaeróbios, largamente utilizados no tratamento de esgotos sanitários, como uma fonte de energia renovável.

Embora o enfoque energético dado ao aproveitamento do metano gerado nos reatores anaeróbios seja relativamente recente, o potencial de geração deste produto gasoso que compreende cerca de 70 a $80 \%$ do biogás dos reatores UASB, é estimado em torno de $350 \mathrm{~L} \mathrm{~kg}^{-1}$ DQO removida (CNTP), entretanto cabe a ressalva de que esse valor é geralmente superior ao que se encontra na realidade (Campos, 1999).

\section{2 - Produção Biológica de Hidrogênio}

A produção biológica de hidrogênio tem se destacado por constituir uma alternativa menos agressiva ao ambiente, pois utiliza matérias-primas renováveis no seu processo, o que lhe confere a vantagem de se realizar independentemente da disponibilidade de combustíveis fósseis que, via de regra, quando empregados contribuem para o aumento da concentração de gases do efeito-estufa decorrentes da sua combustão.

Atualmente mais de $96 \%$ do hidrogênio produzido no mundo é derivado de combustíveis fósseis (Vijayraghavan e Soom, 2004), por isso pesquisas em âmbito mundial estão sendo desenvolvidas explorando a produção biológica de hidrogênio, principalmente via fermentação. 


\subsection{1 - Produção biológica via fermentação}

A fermentação apresenta algumas vantagens em relação à fotossíntese:

- Bactérias fermentativas apresentam maior velocidade de produção de $\mathrm{H}_{2}$;

- A produção de $\mathrm{H}_{2}$ não requer luz;

- Bactérias fermentativas já se encontram condicionadas para produzir $\mathrm{H}_{2}$;

Em condições anaeróbias, parte da matéria orgânica é oxidada e o excesso de elétrons é usado para produzir $\mathrm{H}_{2}$, facilitado pela enzima hidrogenase. Um segundo mecanismo para a produção de hidrogênio ocorre quando NADH é formado através da glicólise (conversão da glicose a piruvato). O NADH é então oxidado conforme mostrado na Reação 3.1.

$\mathrm{NADH}+\mathrm{H}^{+} \rightarrow \mathrm{H}_{2}+\mathrm{NAD}^{+}$ Reação 3.1

As principais desvantagens do processo fermentativo são os rendimentos menores obtidos em relação ao processo fotossintético e o hidrogênio produzido se encontra misturado com $\mathrm{CO}_{2}$, necessitando assim de posterior separação para ser utilizado, dependendo da finalidade.

\subsubsection{1 - Bactérias fermentativas}


Vijayaraghavan e Soom (2004) apontam como as principais bactérias produtoras de hidrogênio: Enterobacter aerogenes, Enterobacter cloacae, Clostridium butyricum, Clostridium pasteurianum, Desulfovibrio vulgaris, Magashaera elsdenii, Citrobacter intermedius e Escherichia coli.

Segundo Hawkes et al. (2002), o rendimento de hidrogênio a partir de espécies de Clostridium é geralmente maior que aquele obtido por bactérias aeróbias facultativas como Enterobacter sp.

\section{3 - Produção de Hidrogênio em Reatores Anaeróbios}

Considerando-se que o processo de digestão anaeróbia possa ser dividido somente em duas grandes etapas, ou seja, em acidogênese e metanogênese, a obtenção de hidrogênio só é possível se o processo for interrompido na primeira etapa, pois o hidrogênio caracteriza-se como um intermediário do processo, sendo produzido na primeira etapa e consumido na segunda.

Cabe aqui a ressalva de que a não-interrupção do processo de digestão anaeróbia levará a produção de metano pelas vias acetoclástica e hidrogenotrófica apresentadas na Figura 3.1 e representadas pelas Reações 3.2 e 3.3, respectivamente, (Gujer e Zehnder, 1983).

$\mathrm{CH}_{3} \mathrm{COOH} \rightarrow \mathrm{CH}_{4}+\mathrm{CO}_{2}$

Reação 3.2

$\mathrm{H}_{2}+0,25 \mathrm{CO}_{2} \rightarrow 0,25 \mathrm{CH}_{4}+0,5 \mathrm{H}_{2} \mathrm{O}$

Reação 3.3 


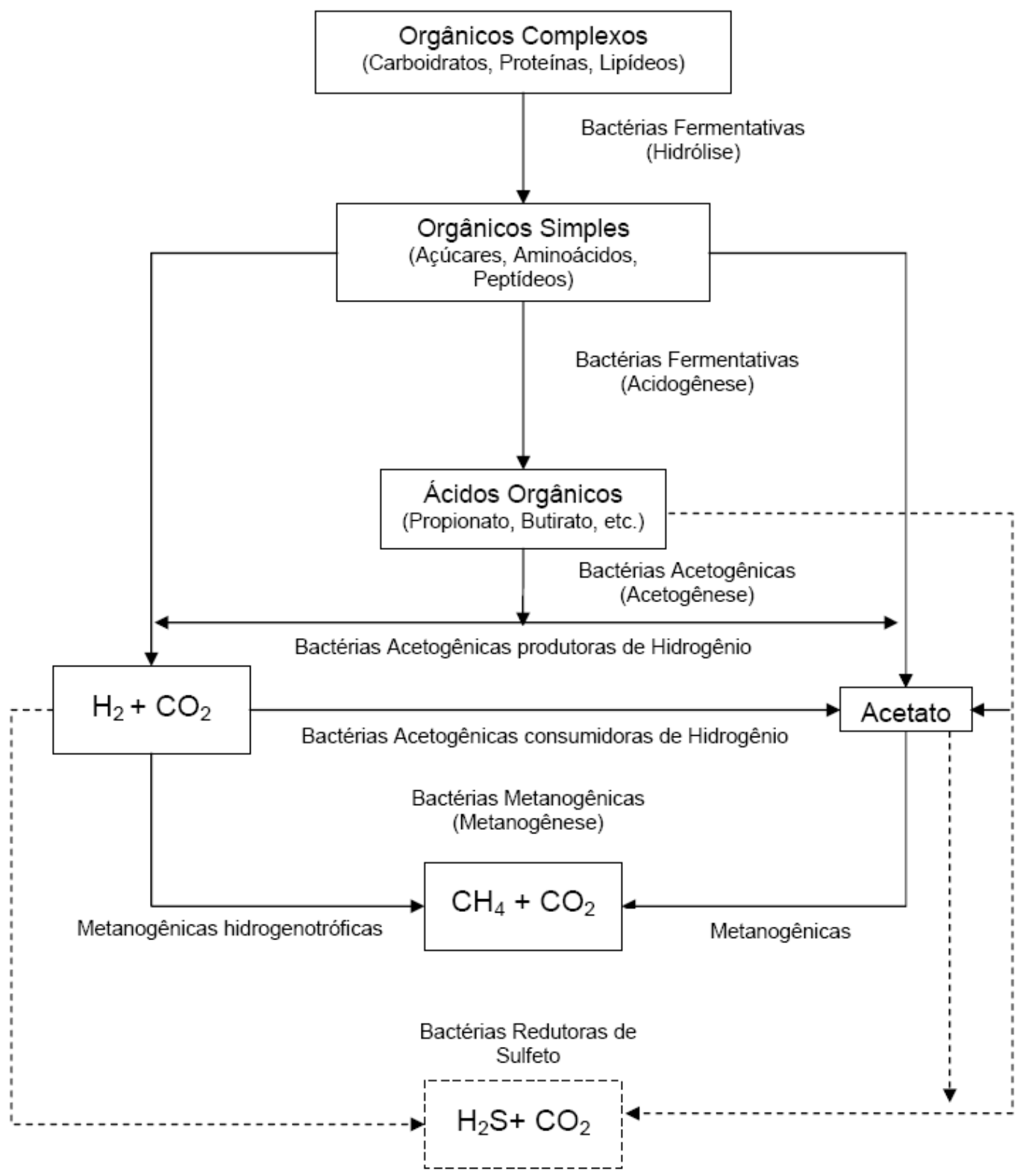

Figura 3.1 - Diagrama simplificado dos pontos de geração e consumo de hidrogênio no processo completo de digestão anaeróbia. (Fonte: Adaptada de Chernicharo, 1997). 
Já a produção de hidrogênio, na primeira etapa do processo, pode ser representada pelas Reações 3.4 e 3.5, nas quais os produtos finais são ácido acético e butírico, respectivamente.

$\mathrm{C}_{6} \mathrm{H}_{12} \mathrm{O}_{6}+2 \mathrm{H}_{2} \mathrm{O} \rightarrow 2 \mathrm{CH}_{3} \mathrm{COOH}+2 \mathrm{CO}_{2}+4 \mathrm{H}_{2} \uparrow$

Reação 3.4

$\mathrm{C}_{6} \mathrm{H}_{12} \mathrm{O}_{6}+2 \mathrm{H}_{2} \mathrm{O} \rightarrow \mathrm{CH}_{2} \mathrm{CH}_{2} \mathrm{CH}_{2} \mathrm{COOH}+2 \mathrm{CO}_{2}+2 \mathrm{H}_{2} \uparrow$

Reação 3.5

Dessa forma, fica claro que é a etapa fermentativa da digestão anaeróbia de resíduos orgânicos o processo que possibilita a produção de hidrogênio, por meio da qual os microrganismos acidogênicos decompõem a matéria orgânica em $\mathrm{H}_{2}, \mathrm{CO}_{2} \mathrm{e}$ ácidos graxos voláteis de cadeia curta conforme apresentado nas Reações 3.4 e 3.5.

Com a finalidade de viabilizar a produção de hidrogênio por meio da inibição da etapa metanogênica são aplicadas estratégias de controle operacional nos reatores, como as apresentadas a seguir.

\subsection{1 - Influência do tempo de detenção hidráulica}

Muitos trabalhos (Chang et al., 2002; Lee et al., 2003; Chen et al., 2004) apresentam como método de inibição da metanogênese a operação em baixos tempos de detenção hidráulica (TDH), que contribui no sentido de carrear as arquéias metanogênicas dos reatores. O arraste desses organismos para fora dos sistemas se dá pelo fato de que a velocidade específica máxima de crescimento $\left(\mu_{\text {máx }}\right)$ das arqueias 
metanogênicas, da ordem de $0,0167 \mathrm{~h}^{-1}$, é bem menor que das bactérias acidogênicas que é cerca de $0,083 \mathrm{~h}^{-1}$. Dessa forma, os microrganismos metanogênicos são incapazes de manter uma população estável e acabam sendo eliminados do sistema (Chen et al., 2001).

Chen e Lin (2004) operaram um reator processando sacarose, voltado para a produção de hidrogênio, sem adaptação do inóculo e, portanto, com a presença provável de microrganismos consumidores de hidrogênio. No entanto, com a diminuição gradual do TDH de 20 para 2,5 dias, chegando posteriormente a 6 h, os autores conseguiram selecionar uma cultura dominada por C. pasteurianum, notadamente uma espécie produtora de hidrogênio.

\subsection{2 - Influência do material suporte}

Em virtude da maioria dos reatores anaeróbios produtores de hidrogênio serem operados com baixos tempos de detenção hidráulica (TDH) (Leite et al., 2008; Chang et al., 2002; Lee et al., 2003; Yokoi et al., 2001; Kumar e Das, 2001; Lin et al., 2006), o uso de materiais suporte para adesão da biomassa torna-se importante para manter concentrações satisfatórias de microrganismos nos sistemas.

O crescimento da biomassa pode se dar em vários tipos de material suporte, dentre eles aparas de polietileno reciclado, que foi o material usado nos trabalhos de Fernandes (2008), Rojas (2010) e Peixoto et al. (2011), o que pode contribuir para a redução dos custos do processo de geração de hidrogênio. Materiais como argila 
expandida e carvão ativado são bastante encontrados nos trabalhos com reatores de leito fixo, principalmente por também representarem soluções de baixo custo.

Além de imobilizar a biomassa, o tipo de material suporte também pode atuar para a seleção de comunidades microbianas de interesse, conforme demonstrou Silva et al. (2006).

No estudo de Silva et al. (2006), em reatores diferenciais usando água residuária sintética como substrato, foram avaliados como material suporte para crescimento de microrganismos anaeróbios: espuma de poliuretano, carvão vegetal, cerâmica e polietileno de baixa densidade, sendo que este último apresentou as características mais favoráveis à produção de hidrogênio, uma vez que favoreceu muito mais a colonização por bactérias fermentativas e hidrolíticas.

Com o uso de polietileno de baixa densidade pelos autores supracitados não houve detecção de metano ou sulfeto de hidrogênio em seus sistemas, o que corroborou a eficácia na seleção de microrganismos.

Chang et al. (2002) estudaram reatores de leito fixo aplicados à produção biológica de hidrogênio via fermentação de sacarose usando como inóculo lodo de esgoto doméstico pré-tratado. Esse estudo consistiu em analisar o efeito da utilização de argila expandida e carvão ativado como material suporte. O reator de $300 \mathrm{~mL}$ utilizado pelos autores supracitados, operando com argila expandida obteve seu melhor resultado com TDH de $2 \mathrm{~h}$, pois atingiu velocidade de produção de $0,415 \mathrm{~L} \mathrm{~h}^{-}$ ${ }^{1} \mathrm{~L}^{-1}$ e 34,9\% de hidrogênio no biogás. Já no reator de 3 L, cujo leito foi constituído de carvão ativado, atingiu-se velocidade de produção máxima de 1,32 $\mathrm{L} \mathrm{h}^{-1} \mathrm{~L}^{-1}$ e $30 \%$ de hidrogênio no biogás, resultados estes que ressaltam a importância na escolha do material suporte. 


\subsection{3 - Importância do pH}

O pH também é um parâmetro operacional de grande importância para a produção de hidrogênio, pois, conforme constataram Fang e Liu (2002), a velocidade de produção de hidrogênio e a ação dos microrganismos hidrogenotróficos (consumidores de hidrogênio) são diretamente afetadas pelo pH. No trabalho desenvolvido pelos autores supracitados, que consistiu na operação de um reator em batelada degradando glicose anaerobiamente, não houve detecção de metano em pH inferior a 5,5.

Entretanto, é importante destacar que o pH abaixo de 4,7 é altamente desfavorável para a produção de hidrogênio, visto que inibe a atividade da hidrogenase e outras enzimas envolvidas no processo (Lay, 1999).

\subsection{4 - Efeito da temperatura}

Na literatura é reportado com freqüência que as melhores eficiências de produção de hidrogênio podem ocorrer em duas faixas de temperatura: a mesofílica (cerca de $37^{\circ} \mathrm{C}$ ) e a termofílica (cerca de $55^{\circ} \mathrm{C}$ ) (Li e Fang, 2007). Porém, a maior parte dos trabalhos nos quais são apresentadas a maior diversidade de microrganismos produtores de hidrogênio são utilizadas temperaturas mesofílicas (Levin et al., 2004).

Zhang e Shen (2005) observaram que a temperatura tem influência considerável na produção de hidrogênio. Os autores argumentam que na faixa de 25 
a $40{ }^{\circ} \mathrm{C}$ ocorrem as melhores eficiências do processo, principalmente devido a condição próxima da ideal $\left(35{ }^{\circ} \mathrm{C}\right)$ para o funcionamento dos catalisadores bioquímicos. No trabalho dos autores supracitados, a máxima porcentagem de hidrogênio encontrada no biogás foi de $42,9 \%$, obtida a $40{ }^{\circ} \mathrm{C}$ em um reator em batelada de $120 \mathrm{~mL}$ de volume útil.

\subsection{5 - Efeito do inóculo}

O efeito do inóculo na produção de hidrogênio é considerável, especialmente em trabalhos em escala de bancada.

Kawagoshi et al. (2005) constataram que o inóculo é um dos fatores determinantes na produção de hidrogênio, pois no estudo realizado pelos referidos autores demonstrou-se que em um mesmo meio, de igual condição nutricional e concentração de substrato, houve variação na produção de hidrogênio de 0,15 mol H $\mathrm{mol}^{-1}$ de glicose (inóculo oriundo de lodos ativados) a 1,35 mol $\mathrm{H}_{2} \mathrm{~mol}^{-1}$ de glicose (inóculo proveniente de lodo anaeróbio digerido).

Diversos autores trabalharam com inóculos obtidos a partir de lodo de tratamento de esgoto (Lee et al., 2003; Wu et al., 2003; Lin e Lay, 2004; Chang et al., 2002), o que constitui uma técnica mais plausível para ser utilizada em sistemas em escala piloto.

Para a utilização de lodo de tratamento de esgoto ou qualquer outro consórcio como fonte de inóculo, pré-tratamentos são necessários para impedir o desenvolvimento de microrganismos consumidores de hidrogênio nos sistemas. 
Entre os pré-tratamentos mais usados (Van Ginkel et al., 2001; Logan et al., 2002;

Chen et al., 2002) destacam-se o tratamento ácido e térmico, por meio dos quais varia-se o pH do lodo de 3 a 6 e a temperatura de $25^{\circ} \mathrm{C}$ a $90{ }^{\circ} \mathrm{C}$, respectivamente.

\subsection{6 - Características do substrato}

O substrato, ou seja, a fonte de carbono orgânico que será utilizada na fermentação direcionada à produção de hidrogênio é de fundamental importância, pois sua composição também define o rendimento do processo.

Constam na literatura muitos trabalhos que utilizam águas residuárias como substrato para o processo fermentativo de produção de hidrogênio (Liu e Fang, 2002; Van Ginkel et al., 2005; Zhu et al., 2002; Ueno et al., 1996; Yu et al., 2002; Zhang et al., 2004), porém dentre estes, o trabalho desenvolvido por Van Ginkel et al. (2005) é o único a avaliar água residuária doméstica como fonte para obtenção de hidrogênio. Neste trabalho os autores investigaram, em reatores em batelada, o potencial de geração de hidrogênio a partir de água residuária de indústria de processamento de maçã, de batata, de fábrica de doces e de origem doméstica (esgoto sanitário).

O experimento que forneceu os resultados sobre o potencial da água residuária doméstica iniciou-se com a coleta do esgoto sanitário na entrada de uma estação de tratamento de esgoto. Após a coleta, o efluente foi concentrado 25 vezes, proporcionando $294 \mathrm{mg} \mathrm{L}^{-1}$ de glicose solúvel. As amostras concentradas foram adicionadas a reatores em batelada de $294 \mathrm{~mL}$ de volume total, sendo $150 \mathrm{~mL}$ de 
meio reacional e $144 \mathrm{~mL}$ de headspace, mantidos a temperatura de $23{ }^{\circ} \mathrm{C}$. Ao meio reacional foi adicionado $1 \mathrm{~g}$ de inóculo proveniente de amostras de solo tratadas termicamente $\left(100{ }^{\circ} \mathrm{C}\right.$ por 2 h) para selecionar as bactérias produtoras de hidrogênio, uma vez que a grande maioria é formadora de esporos e, portanto, resistente ao calor. Também foi adicionada uma solução de ácido etanosulfônico monoidratado para ajustar o pH a 6,1. Ao final do experimento, que durou 200 horas, o pH foi reduzido para 5,9. A concentração de hidrogênio no gás produzido ficou em torno de $23 \%$

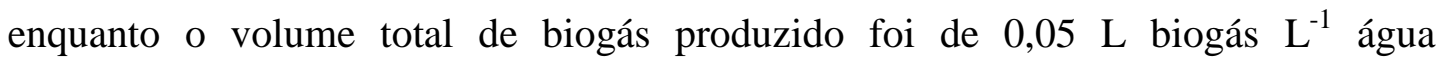
residuária, que resultou em $0,010 \mathrm{~L} \mathrm{H}_{2} \mathrm{~L}^{-1}$ água residuária. Quanto à relação entre a DQO e a produção de hidrogênio, obteve-se $0,04 \mathrm{~L} \mathrm{H}_{2} \mathrm{~g}^{-1}$ DQO e a remoção total de DQO atingiu $17,0 \%$.

Cabe acrescentar que experimento similar em reatores em batelada foi desenvolvido por Fernandes et al. (2010) a partir de esgoto sanitário, porém sem a etapa de concentração do efluente. Neste experimento obteve-se 0,200 L H $\mathrm{H}^{-1}$ DQO para uma água residuária com uma DQO equivalente a $250 \mathrm{mg} \mathrm{L}^{-1}$, o que representou um bom resultado, uma vez que no trabalho de Van Ginkel et al. (2005) o redimento na produção de hidrogênio foi muito menor.

A maior parte dos trabalhos na literatura usa, como afluente aos reatores fermentativos, substratos sintéticos que contêm glicose ou sacarose como fonte de carbono orgânico, pois os carboidratos são a fonte de carbono orgânico que proporciona o melhor desempenho na geração de hidrogênio (Hawkes et al., 2002; Okamoto et al., 2000; Chong et al., 2009; Van Ginkel et al., 2005; Das e Veziroglu, 2001; Lay et al., 2003) e por esse motivo são usados como substrato na maior parte dos estudos que envolve a produção de hidrogênio. 
Além disso, na maioria dos trabalhos, também são frequentemente observadas suplementações inorgânicas que tem como referência as formulações usadas no trabalho de Bahl et al. (1982) ou no estudo desenvolvido por Endo et al. (1982).

\subsubsection{1 - Influência das razões $\mathrm{C} / \mathrm{N}$ e $\mathrm{C} / \mathrm{P}$}

Van Ginkel et al. (2005) para demonstrar a influência da concentração de macronutrientes sobre a produção de hidrogênio a partir de água residuária doméstica e de processamento de alimentos, realizaram análises preliminares sobre as concentrações de nitrogênio $\left(\mathrm{NH}_{3}-\mathrm{N}\right)$ e fósforo $\left(\mathrm{P}^{-} \mathrm{PO}_{4}^{-3}\right)$. Os resultados obtidos sugeriram que esses dois nutrientes seriam limitantes na maior parte das águas residuárias para a atividade dos microrganismos utilizados em sistemas de tratamento. Os autores avaliaram o potencial para a produção de hidrogênio de cada água residuária com e sem a adição de nutrientes ( $\mathrm{N}, \mathrm{P}$ e metais traço) para se determinar a necessidade de suplementação. Os resultados apresentados demonstraram que a água residuária proveniente da indústria de balas, cuja DQO era de $20 \mathrm{~g} \mathrm{~L}^{-1}$, apresentou uma evolução de 0,02 para 0,10 $\mathrm{L} \mathrm{H}_{2} \mathrm{~g}^{-1}$ de DQO com a adição de nutrientes. No entanto, essa mesma água residuária com DQO de 0,6 g L ${ }^{-1}$, não apresentou diferença na produção de hidrogênio mesmo com a adição de nutrientes, o que apontou para a necessidade de um balanceamento entre a fonte de carbono e os macronutrientes, não deixando de considerar a influência dos micronutrientes, pois Hawkes et al. (2002) destacam que concentrações de ferro 
inferiores a $0,56 \mathrm{mg} \mathrm{L}^{-1}$ passam a ser fatores limitantes para o crescimento da bactéria Clostridium pasteurianum.

De acordo com Lin e Lay (2004), a razão entre carbono e nitrogênio pode influir significativamente no conteúdo de hidrogênio no biogás e na velocidade de formação do mesmo.

Rojas (2010) avaliou o efeito das razões $\mathrm{C} / \mathrm{N}$ de 40, 90, 140 e 190 na produção de hidrogênio a partir de água residuária sintética a base de sacarose. Em seu trabalho reatores de leito fixo e fluxo ascendente, com polietileno de baixa densidade para a adesão de biomassa, foram operados a $25{ }^{\circ} \mathrm{C}$ e tempo de detenção hidráulica (TDH) de 2 horas, tendo como variável a concentração de uréia no meio de alimentação. Os melhores resultados em termos de produtividade de hidrogênio e composição do mesmo no biogás foram alcançados com a razão C/N de 140. Esses resultados correspondem aos valores médios de 2,2 $\mathrm{mol} \mathrm{H}_{2} \mathrm{~mol}^{-1}$ sacarose e $61 \%$ de hidrogênio no biogás em contraste com 0,6 mol $\mathrm{H}_{2} \mathrm{~mol}^{-1}$ sacarose e 53\% de hidrogênio no biogás obtidos com a razão $\mathrm{C} / \mathrm{N}$ de 40 , que foi a condição avaliada que apresentou o pior desempenho.

Segundo Rojas (2010), sob excesso de nitrogênio, o crescimento da biomassa é maior, o que gera efeitos negativos sobre a produção de hidrogênio, enquanto a carência de nitrogênio permite o controle do crescimento da biomassa, o que resulta em maiores produtividades de hidrogênio, embora em todas as razões $\mathrm{C} / \mathrm{N}$ testadas tenha havido queda na produção de biogás. Provavelmente devido a atuação de bactérias hidrogênio-oxidantes.

Srrethawong et al. (2010) avaliaram o efeito da variação das relações DQO : N de 100:2,2, 100:3,3 e 100:4,4 usando um reator anaeróbio operado em bateladas 
sequenciais (ASBR) de $4 \mathrm{~L}$ operado a $37{ }^{\circ} \mathrm{C}$ para produzir hidrogênio a partir água residuária de processamento de mandioca. A menor relação DQO: N (100:2,2) resultou em uma velocidade de produção de gás de 2,3 $\mathrm{L} \mathrm{h}^{-1}$, com 40,6\% de $\mathrm{H}_{2}$ no biogás, $10500 \mathrm{mg} \mathrm{L}^{-1}$ de sólidos suspensos voláteis (SSV) e concentrações de aproximadamente $500 \mathrm{mg} \mathrm{L}^{-1}, 100 \mathrm{mg} \mathrm{L}^{-1}, 1100 \mathrm{mg} \mathrm{L}^{-1}$ e 200 $\mathrm{mg} \mathrm{L}^{-1}$ de ácido acético, ácido propiônico, ácido butírico e ácido valérico, respectivamente. A maior relação DQO:N (100:4,4) resultou em uma velocidade de produção de gás de 2,1 $\mathrm{L} \mathrm{h}^{-1}$, com 27,2\% de $\mathrm{H}_{2}$ no biogás, 12000 $\mathrm{mg} \mathrm{L}^{-1}$ (SSV) e concentrações de aproximadamente $300 \mathrm{mg} \mathrm{L}^{-1}, \quad 310 \mathrm{mg} \mathrm{L}^{-1}$, $4500 \mathrm{mg} \mathrm{L}^{-1}$, $2500 \mathrm{mg} \mathrm{L}^{-1}$ e $10.300 \mathrm{mg} \mathrm{L}^{-1}$ de ácido acético, ácido propiônico, ácido butírico, ácidovalérico e etanol, respectivamente. Com base nestes resultados, Srrethawong et al. (2010) argumentaram que a presença excessiva de nitrogênio no meio muda a rota metabólica dos microrganismos direcionados para a produção de hidrogênio, o que leva ao crescimento dos mesmos em vez da produção de gás e aumenta a geração de compostos menos reduzidos, que aprisionam o hidrogênio em cadeias de ácidos e solventes impedindo a sua liberação como biogás.

Os efeitos das relações entre os macronutrientes também foram estudados por Argun et al. (2008). Os referidos autores realizaram experimentos em reatores em batelada de $2 \mathrm{~L}$ incubados a $37^{\circ} \mathrm{C}$, nos quais a razão $\mathrm{C} / \mathrm{N}$ do meio foi variada entre 20 e 200, enquanto a razão C/P variou entre 50 e 1000. Estes experimentos foram conduzidos para determinar a influência dessas razões sobre o rendimento e a taxa de formação de hidrogênio a partir da fermentação de uma solução de farinha de trigo. Os resultados obtidos por Argun et al. (2008) demonstraram que, em baixa razão C/N (<46), a produção de hidrogênio aumentou à medida que a razão C/P diminuiu, 
demonstrando assim que mais fósforo é requerido em concentrações mais altas de nitrogênio. Em razões C/N mais altas (> 110), o rendimento de hidrogênio aumentou quando a razão C/P também aumentou, demonstrando baixa necessidade de fósforo em concentrações baixas de nitrogênio. Os requisitos de $\mathrm{N}$ e P foram proporcionais um ao outro e à fonte de carbono como resultado da estequiometria predominante do metabolismo anaeróbio. A maior produção de hidrogênio, 281 mL $\mathrm{H}_{2}$ g$^{1}$ de amido, foi obtida com a maior razão C/N e C/P, que correspondeu a 200 e 1000, respectivamente. Os autores concluíram que as razões $\mathrm{C} / \mathrm{N}$ e $\mathrm{C} / \mathrm{P}$ mais altas atingiram melhor performance na produção de hidrogênio porque pequenas concentrações de nitrogênio e fósforo são necessárias para o baixo crescimento dos microrganismos anaeróbios. Segundo Argun et al. (2008), altas concentrações de nitrogênio e fósforo estariam inibindo a formação de hidrogênio por meio de alterações das rotas metabólicas dos microrganismos envolvidos.

\subsubsection{2 - Influência da razão S/X}

Cheng et al. (2006), estudando a cinética de bactérias produtoras de hidrogênio a partir de sacarose, soro de leite em pó e restos de alimentos, avaliou, entre outros parâmetros, a influência da razão S/X em reatores em batelada de 250 $\mathrm{mL}$ operados a $36{ }^{\circ} \mathrm{C}$ com $\mathrm{pH}$ inicial de 5,5. Os autores verificaram que a eficiência na produção de hidrogênio está fortemente relacionada com o controle da razão de substrato para biomassa $(\mathrm{S} / \mathrm{X})$, pois esse parâmetro afeta significativamente as características metabólicas e cinéticas dos microrganismos. 
Os resultados obtidos por Chen et al. (2006) mostraram que o maior rendimento alcançado, cerca de $234 \mathrm{~mL} \mathrm{H}_{2} \mathrm{~g}^{-1}$ DQO a partir de sacarose foi obtido com uma razão S/X de 7,3 g DQO g ${ }^{-1} \mathrm{SSV}$, indicando que para substratos com sacarose ou outro carboidrato de fácil degradação a produção específica máxima de hidrogênio é atingida com baixas razões de S/X.

\subsection{7 - Reatores de leito fixo}

Wu et al. (2002) compararam o desempenho de reatores com células suspensas e com células imobilizadas em diferentes suportes: gel de alginato e gel de alginato combinado com carvão ativado. Os autores observaram que a produção de hidrogênio foi maior para as células aderidas ao suporte de gel de alginato com carvão ativado. O reator de células suspensas apresentou os piores resultados. De acordo com os autores a produção biológica de hidrogênio em sistemas com células suspensas é normalmente ineficiente para reatores contínuos, já que resulta em problemas com o reciclo da biomassa, dificultando a obtenção de concentração celular suficiente para que se consiga alta produção de hidrogênio. Devido a esse fato, o reator de leito fixo, por apresentar suporte para aderência dos microrganismos, apresenta os melhores resultados em operações contínuas com baixos tempos de detenção hidráulica (TDH).

Lee et al. (2003), utilizando reatores de leito empacotado compostos por material suporte de carvão ativado destinados à produção anaeróbia de $\mathrm{H}_{2}$ a partir de sacarose e usando lodo de esgoto como inóculo, avaliaram a produção de hidrogênio 
mediante o efeito da porosidade e do tempo de detenção hidráulica (TDH) em 3 colunas preenchidas com carvão ativado. Os 3 reatores tiveram seus respectivos leitos constituídos de carvão ativado de forma a proporcionar porosidades de 70, 80 e 90\%. Os melhores resultados obtidos quanto à fração de hidrogênio no biogás, velocidade de produção de hidrogênio, eficiência de utilização de substrato e rendimento, foram respectivamente: $34 \%, 2,6 \mathrm{~L} \mathrm{~h}^{-1} \mathrm{~L}^{-1}$, 91\%, $2 \mathrm{~mol} \mathrm{H}_{2} \mathrm{~mol}^{-1}$ sacarose para a porosidade de 70\% com TDH de $1 \mathrm{~h}, 31 \%, 4,1 \mathrm{~L} \mathrm{~h}^{-1} \mathrm{~L}^{-1}, 83 \%, 1,6$ mol $\mathrm{H}_{2} \mathrm{~mol}^{-1}$ sacarose para a porosidade de $80 \%$ com TDH de 0,5 h e $37 \%, 7,4 \quad \mathrm{~L}$ $\mathrm{h}^{-1} \mathrm{~L}^{-1}, 92 \%$ e 2,9 1,6 mol $\mathrm{H}_{2} \mathrm{~mol}^{-1}$ sacarose para a porosidade de $90 \%$ com TDH de 0,5 h. Desta maneira, nota-se que a produção de hidrogênio é favorecida tanto pela eficiência de imobilização da biomassa em leitos fixos quanto pela manutenção de uma elevada porosidade nos mesmos.

\subsection{8 - Operação de um sistema fermentativo de dois estágios destinado a produção de hidrogênio e metano}

Segundo de Del Nery (1993), sistemas de digestão anaeróbia de duas fases podem apresentar vantagens no tratamento de águas residuárias, pois são mais estáveis que sistemas de estágio único, uma vez que o primeiro estágio (acidogênico) tem melhor capacidade de assimilar choques de carga orgânica, variações de pH e de temperatura. 
No primeiro estágio, a matéria orgânica é hidrolisada e fermentada para produzir ácidos orgânicos e hidrogênio, enquanto no segundo estágio os ácidos orgânicos são convertidos a metano pelas arqueias metanogênicas.

Cabe salientar que, embora haja uma separação física entre o reator acidogênico e o metanogênico, o processo de digestão anaeróbia em dois estágios dificilmente será separado por completo, como aponta Del Nery (1993).

Cooney et al. (2007) operaram dois reatores anaeróbios de mistura integrados em escala de bancada, direcionados para a obtenção de hidrogênio e metano a partir de um substrato com concentração de $10 \mathrm{~g} \mathrm{~L}^{-1}$ de glicose mais um meio nutricional específico. Os volumes dos reatores utilizados foram de 4,7 L e 18,8 L para o reator produtor de hidrogênio e para o gerador de metano, respectivamente. A diferença notável entre o volume dos reatores se deve a condição operacional aplicada a cada um, ou seja, para o reator acidogênico, cujas populações de microrganismos crescem a uma alta velocidade, pode ser aplicado um baixo tempo de detenção hidráulica, que resulta num sistema com menor volume. Entretanto, para o reator metanogênico o tempo de detenção hidráulica tem que ser mais elevado devido a menor velocidade de crescimento dos microrganismos dessa etapa, o que gera a necessidade um sistema com maior volume.

Na digestão anaeróbia de duas fases realizada pelo sistema desenvolvido por Cooney et al. (2007), o reator acidogênico foi operado com tempo de detenção hidráulica de 0,4 dia e mantido a $35{ }^{\circ} \mathrm{C}$ e pH 5,5. Nestas condições operacionais o melhor desempenho apresentado em termos de produtividade relacionada ao volume reacional, rendimento em função da glicose, velocidade de produção de biogás e fração de produto no biogás, foi respectivamente de 84,57 mmol L ${ }^{-1} \mathrm{~d}^{-1}, 0,34 \mathrm{mmol}$ 
mmol $^{-1}$ substrato, 446,06 $\mathrm{mL} \mathrm{h}^{-1}$ e 39,9\% de $\mathrm{H}_{2}$, ao passo que no reator metanogênico operado a uma vazão específica de alimentação de $0,33 \mathrm{~d}^{-1}$, $35{ }^{\circ} \mathrm{C}$ e $\mathrm{pH} 7,0$, os melhores resultados obtidos foram respectivamente $12,95 \mathrm{mmol} \mathrm{L}^{-1} \mathrm{~d}^{-1}, 0,06 \mathrm{mmol}$ $\mathrm{mmol}^{-1}$ substrato, $867,47 \mathrm{~mL} \mathrm{~h}^{-1}$ e $23,1 \%$ de $\mathrm{CH}_{4}$.

No trabalho de Ueno et al. (2007) foram utilizados dois reatores em escala piloto destinados a operar com separação de fases visando a produção de hidrogênio e metano. O primeiro reator do processo foi um reator de mistura (CSTR) com $100 \mathrm{~L}$ de volume efetivo destinado à produção de hidrogênio, seguido por um reator de leito empacotado com recirculação interna (IRPR) com 340 L de volume efetivo voltado para a produção de metano. O substrato utilizado na alimentação do sistema foi resíduo sólido orgânico composto de restos de alimentos, com DQO dissolvida de

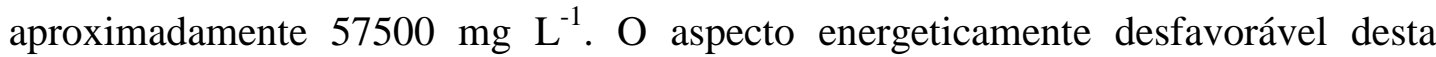
planta piloto foi a inclusão de sistemas de aquecimento para ambos os reatores, os quais ficaram submetidos a uma temperatura de aproximadamente $55{ }^{\circ} \mathrm{C}$. Nestas condições obteve-se como melhores resultados, em termos de produto por volume de água residuária, 5,4 $\mathrm{m}^{3} \mathrm{~m}^{-3} \mathrm{~d}^{-1}$ de hidrogênio produzido com o reator CSTR operando com TDH de 1,2 dia e $6,1 \mathrm{~m}^{3} \mathrm{~m}^{-3} \mathrm{~d}^{-1}$ de metano produzidos com o reator IRPR sendo operado a um TDH de 6,8 dias.

É importante salientar que não foram encontrados trabalhos publicados em periódicos de grande abrangência reportando a produção seqüencial de hidrogênio e metano em reatores contínuos a partir de esgoto sanitário.

Além dos trabalhos de van Ginkel (2005) e Fernandes et al. (2010), que relataram a ausência de produção ou baixa geração de hidrogênio a partir de esgoto sanitário, outros estudos como o de Xiao e Liu (2009) utilizaram o lodo gerado no 
tratamento de esgotos como substrato para a produção de hidrogênio, que foi viabilizada apenas quando este lodo passou por processo de esterilização a fim de destruir culturas que poderiam interferir na produção de hidrogênio e solubilizar a matéria-orgânica, de modo a aumentar principalmente a concentração de carboidratos, o que evidenciou a grande dificuldade de geração de hidrogênio a partir de esgoto doméstico sem qualquer pré-tratamento.

\subsection{9 - Considerações Finais}

Segundo Peixoto (2008), uma das inferências sobre a instabilidade na produção de hidrogênio no reator anaeróbio de leito empacotado indicou como possível causa do problema a redução do volume útil pelo crescimento excessivo de biomassa entre os suportes. Constatação semelhante foi feita por Fernandes (2008), que trabalhou com a mesma configuração de reator. No intuito de superar essa limitação técnica, foi projetado para o desenvolvimento desse trabalho um novo reator com leito fixo e fluxo ascendente, no qual os suportes foram distribuídos uniformemente, de tal maneira que tornou-se possível regular o volume intersticial entre os suportes visando a manutenção da porosidade inicial durante a operação do reator.

Apesar da constatação do problema no reator anaeróbio de leito fixo com suporte empacotado, a primeira e segunda etapas deste trabalho contemplam o estudo da produção de hidrogênio neste reator, pois o esgoto sanitário ainda não havia sido utilizado como substrato para a geração de hidrogênio nessa configuração. 


\section{CAPÍTULO 4}

\section{MATERIAL E MÉTODOS}

Os experimentos foram planejados para avaliar a produção de $\mathrm{H}_{2}$ seguida pela geração de $\mathrm{CH}_{4}$, em dois estágios, usando esgoto bruto e esgoto suplementado com efluentes industriais como substratos. Foram usados reatores em batelada, reatores de leito fixo com diferentes materiais suporte e um reator de manta de lodo.

\section{1 - Reatores}

\subsection{1 - Reatores contínuos}

A Figura 4.1 mostra as duas configurações de reatores contínuos de leito fixo e fluxo ascendente empregados para a realização desse trabalho.

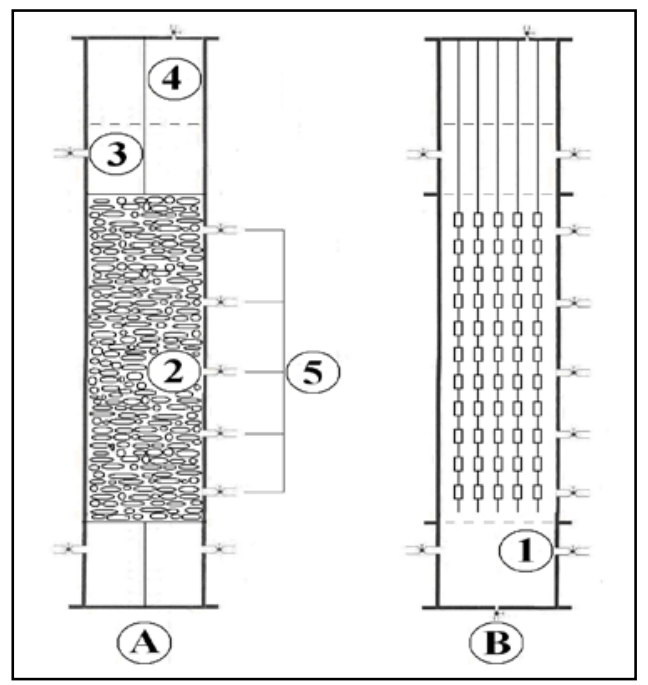

A - Reator de leito empacotado;

B - Reator de leito estruturado;

1 - Zona de entrada ;

2 - Zona do leito;

3 - Zona de saída;

4 - Headspace;

5 - Amostradores;

Figura 4.1 - Desenho esquemático dos reatores de leito fixo utilizados neste trabalho. 
No reator tipo A (Figura 4.1), a zona do leito foi preenchida por aparas cilíndricas de polietileno de baixa densidade e empacotada até atingir a altura de 50 cm. No reator tipo B, o leito tinha a mesma altura, mas era estruturado por meio de hastes de fixação para os materiais suporte em forma de cilindros. O uso dessas duas configurações visou avaliar o efeito do ordenamento do material suporte em relação à colmatação do leito do reator.

A Tabela 4.1 traz a identificação de cada segmento dos reatores bem como suas respectivas dimensões.

Tabela 4.1 - Dimensões dos reatores nas configurações A e B.

\begin{tabular}{lcc}
\hline \multicolumn{1}{c}{ Característica } & Leito fixo empacotado & Leito fixo estruturado \\
\hline Diâmetro interno & $8 \mathrm{~cm}$ & $8 \mathrm{~cm}$ \\
Altura total & $74 \mathrm{~cm}$ & $74 \mathrm{~cm}$ \\
Altura útil & $69 \mathrm{~cm}$ & $70 \mathrm{~cm}$ \\
Zona de entrada & $8 \mathrm{~cm}$ & $8 \mathrm{~cm}$ \\
Zona do leito & $50 \mathrm{~cm}$ & $50 \mathrm{~cm}$ \\
Zona de saída & $15 \mathrm{~cm}$ & $14 \mathrm{~cm}$ \\
Porosidade do leito & $55 \%$ & $58 \%$ \\
Headspace & $4 \mathrm{~cm}$ & $4 \mathrm{~cm}$ \\
Distância entre amostradores & $10 \mathrm{~cm}$ & $10 \mathrm{~cm}$ \\
\hline
\end{tabular}

É importante ressaltar que os reatores construídos com as configurações A e B, possuíam dois acessos para o substrato afluente na zona de entrada, conforme mostrado na Figura 4.1. Esses acessos possibilitaram que houvessem duas correntes de alimentação para o reator, as quais foram empregadas nos testes em que houve suplementação do esgoto sanitário.

Na Figura 4.2, é mostrado o esquema do reator anaeróbio de manta de lodo e fluxo ascendente (UASB) que também foi utilizado neste projeto. O principal 
objetivo desse reator foi atuar como uma unidade acoplada ao reator produtor de hidrogênio com a finalidade de gerar metano e reduzir a concentração de matéria orgânica.

Inicialmente, este reator operou desvinculado da primeira unidade para que o desempenho do mesmo fosse avaliado antes da integração com o reator produtor de hidrogênio.

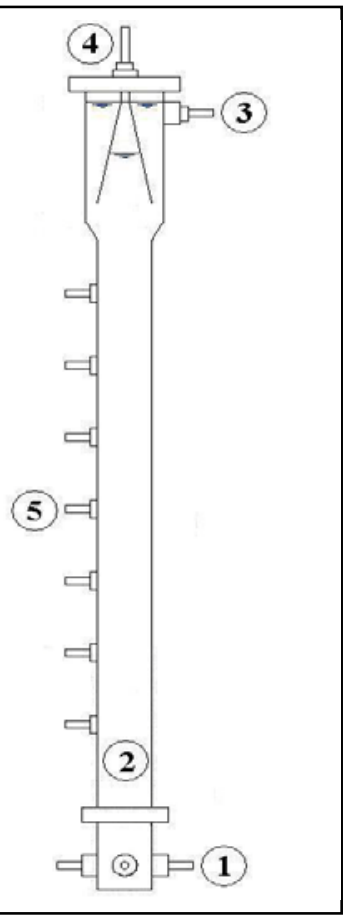

1 - Zona de entrada e distribuidor do afluente;

2 - Manta de lodo;

3 - Zona de saída do efluente líquido;

4 - Zona de saída do efluente gasoso;

5 - Amostradores;

Figura 4.2 - Desenho esquemático do reator de manta de lodo.

A Tabela 4.2 traz as principais dimensões do reator. 
Tabela 4.2 - Dimensões do reator de manta de lodo.

\begin{tabular}{lc}
\hline \multicolumn{1}{c}{ Característica } & UASB \\
\hline Diâmetro interno & $6,5 \mathrm{~cm}$ \\
Altura total & $113 \mathrm{~cm}$ \\
Altura útil & $95 \mathrm{~cm}$ \\
Zona da manta & $79 \mathrm{~cm}$ \\
Distância entre pontos de coleta & $10 \mathrm{~cm}$ \\
\hline
\end{tabular}

O material empregado na confecção dos reatores contínuos (acidogênicos e metanogênico) foi acrílico por facilitar a visualização de alguns aspectos operacionais dos reatores. As dimensões dos reatores foram obtidas adotando-se volumes compatíveis com a escala de bancada. O diâmetro interno foi determinado a partir do tamanho comercial disponível de tubo de acrílico. As demais dimensões foram calculadas a partir destes dois valores.

Para a alimentação dos reatores usados neste trabalho foram usadas três tipos de bombas, cada qual listada com sua respectiva função, conforme mostrado na Tabela 4.3.

Tabela 4.3 - Bombas utilizadas e função no sistema de alimentação.

\begin{tabular}{ll}
\hline \multicolumn{1}{c}{ Tipo / Modelo da bomba } & \multicolumn{1}{c}{ Função } \\
\hline Centrífuga / Thebe ${ }^{\circledR}$ 1/2 CV & Captação do esgoto \\
Diafragma / Prominent ${ }^{\circledR}$ & $\begin{array}{l}\text { Corrente de fornecimento de substrato para os } \\
\text { Concept Plus }\end{array}$ \\
reatores contínuos \\
Minipuláltica / Gilson ${ }^{\circledR}$ & $\begin{array}{l}\text { Corrente de fornecimento de substrato para os } \\
\text { reatores contínuos }\end{array}$ \\
\hline
\end{tabular}

\subsubsection{1 - Material suporte}


Para a configuração de reator tipo A (leito empacotado) foram empregadas aparas de polietileno de baixa densidade cortadas com dimensão aproximada de 10:10:30 mm. A escolha desse material foi condicionada à alta resistência ao desgaste por corrosão e atrito, por ter sido utilizado com sucesso nos trabalhos de Fernandes (2008), Rojas (2010) e Peixoto et al. (2011), e por promover baixa adesão de microrganismos redutores de sulfato e metanogênicos (Silva et al., 2006), que são indesejáveis ao processo. Além disso, este material pode ser obtido facilmente como apara de sistemas extrusores de plástico reciclável, o que lhe confere baixo custo e boa disponibilidade. A aparência deste suporte cortado é mostrada na Figura 4.3.

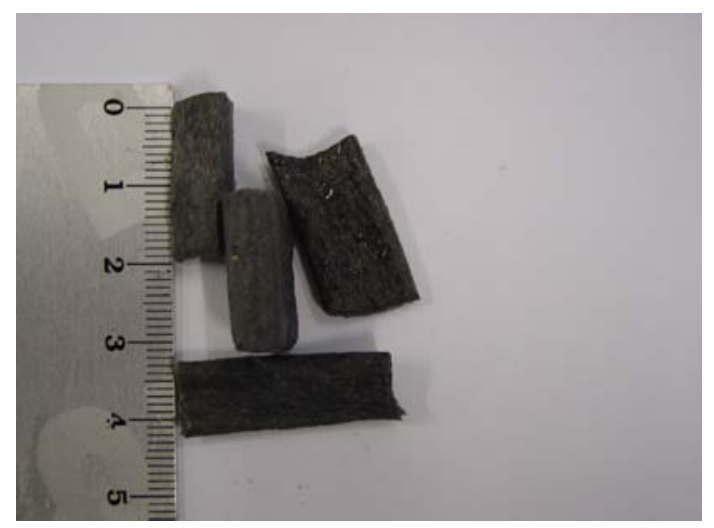

Figura 4.3 - Detalhe do material suporte empregado na confecção dos leitos fixos empacotados.

As aparas de polietileno cortadas foram submetidas a ensaios de granulometria realizados no Departamento de Geotecnia da Escola de Engenharia de São Carlos. Para a realização dos ensaios, as amostras do material suporte com peso previamente determinado foram submetidas ao processo de peneiramento, no qual passaram por peneiras com abertura comercial de: 19,00 mm, 15,90 mm, 12,50 mm, 9,52 mm 7,93 mm e 6,35 mm. O ensaio foi realizado em Agitador Solotest $\left(\mathrm{n}^{\circ} 7\right.$, série 0805, Referencia - 1202230) com duração de 13 minutos à agitação constante. 
Finalizada essa etapa, as massas retidas em cada peneira foram pesadas e construiuse a curva granulométrica.

O material suporte foi caracterizado em termos de diâmetro médio (D50), diâmetros máximos e mínimos e índice de uniformidade C, que é a relação entre o D60/D10, na qual D60 é a abertura da peneira em que passa 60\% do material suporte e D10 é a abertura da peneira em que passa $10 \%$.

Os resultados da caracterização desse material estão apresentados na Tabela 4.4, e a curva de distribuição granulométrica, na Figura 4.4.

Tabela 4.4 - Caracterização das aparas de polietileno de baixa densidade.

\begin{tabular}{|c|c|}
\hline Característica & Resultado \\
\hline D50 & $12,70(\mathrm{~mm})$ \\
\hline D10 & $14,50(\mathrm{~mm})$ \\
\hline D60 & 11,15 (mm) \\
\hline C & 1,26 \\
\hline
\end{tabular}

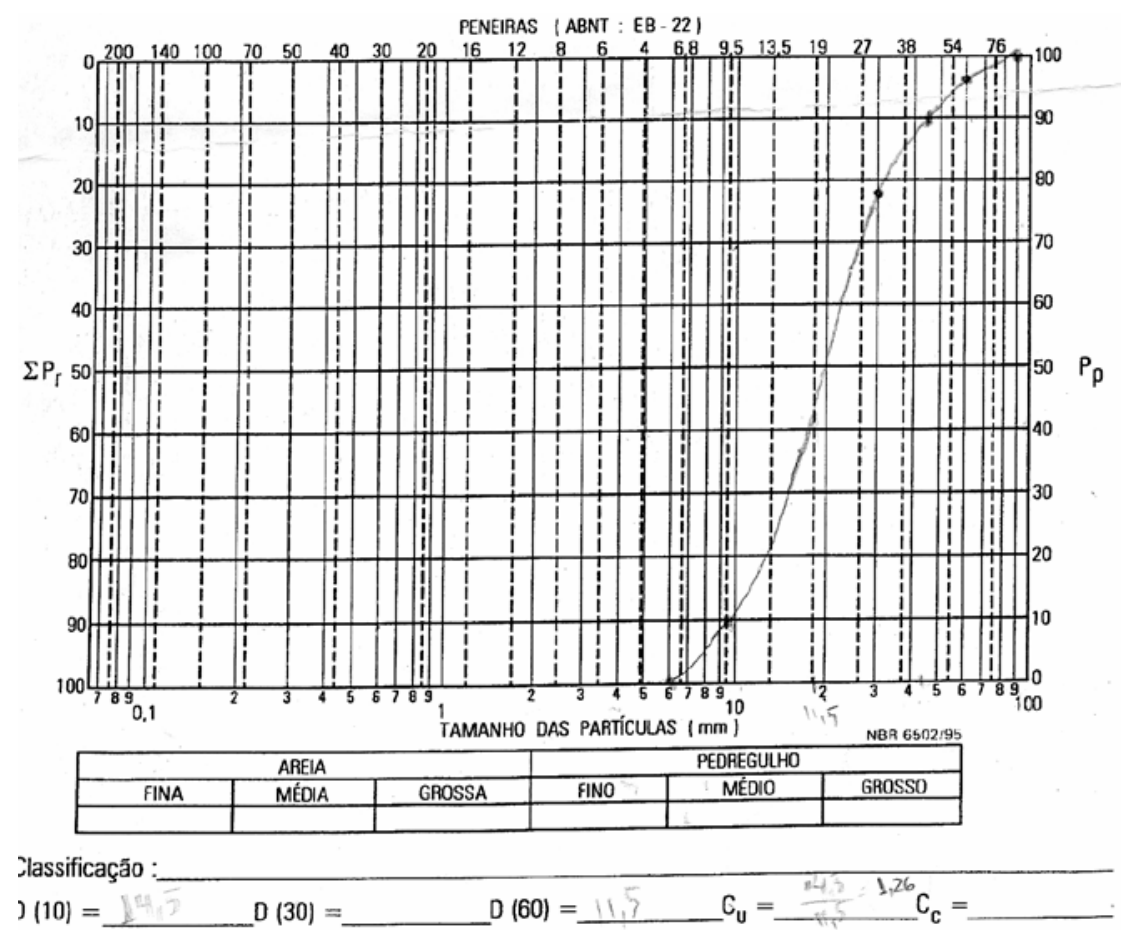

Figura 4.4 - Curva de distribuição granulométrica das aparas de polietileno. 
Segundo o método utilizado, proposto por Caputo (1988), o índice C, calculado com base nas curvas de distribuição granulométrica, indica que os grãos são considerados muito uniformes se $C<5$, de uniformidade média se $5<C<15$, e de granulometria desuniforme se $\mathrm{C}>15$.

O índice de uniformidade obtido para as aparas de polietileno foi de 1,26, o que conferiu a característica de muito uniforme a esse material suporte, que constituiu os leitos fixos dos reatores da configuração A.

Na configuração de reator tipo B (leito estruturado) foram testados três materiais suporte: polietileno de baixa densidade, o mesmo material da configuração tipo A, espuma de poliuretano e cerâmica especial (sílica aluminosa), sendo que os dois últimos materiais foram os mesmos empregados por Rêgo (2002).

Os suportes cilíndricos de polietileno foram adquiridos da empresa Ambio Engenharia, sediada na cidade do Rio de Janeiro-RJ. Já os cilindros de espuma e sílica aluminosa foram confeccionados a partir de espuma de colchão D33 e tijolos refratários para alto-fornos, respectivamente.

Os materiais suporte utilizados na configuração de reator tipo $\mathrm{B}$, conforme mostrados na Figura 4.5, foram cilindros que possuíam um furo central e foram empilhados um sobre o outro nas hastes de aço do reator, de maneira a formar uma coluna que compreendesse toda a extensão da zona do leito. As colunas formadas ocuparam um volume definido, de forma que a porosidade do leito permaneceu muito próxima à utilizada na configuração de reator tipo A, ou seja, com 58\% de vazios desconsiderando a porosidade intrínseca de cada material suporte. 


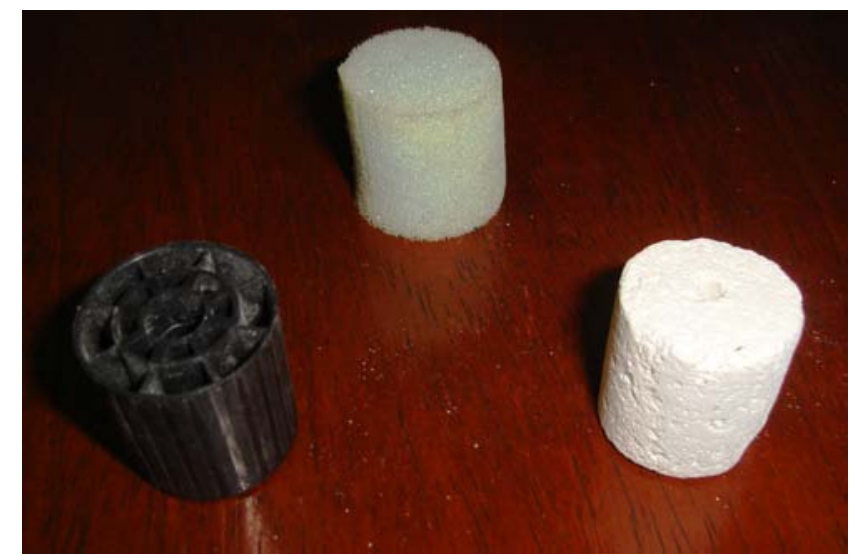

Figura 4.5 - Fotografia dos cilindros de polietileno, espuma e cerâmica (da esquerda para a direita).

As cinco hastes que suportaram os cilindros foram distribuídas de maneira eqüidistante no formato de um pentágono, conforme mostrado na Figura 4.6.

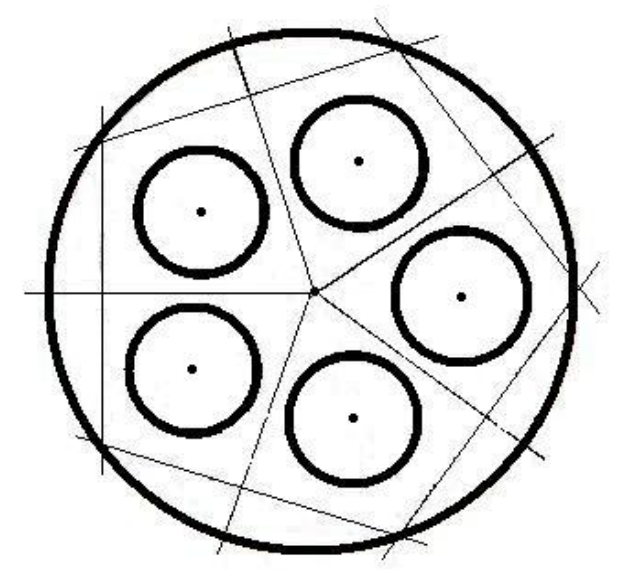

Figura 4.6 - Representação da vista superior dos reatores com leito estruturado e da disposição dos suportes cilíndricos. As linhas finas denotam a distribuição equidistante dos suportes.

Os cilindros de polietileno, espuma e cerâmica apresentaram respectivamente as seguintes dimensões: 23 mm de diâmetro e 25 mm de altura, 24 mm de diâmetro e 25 mm de altura e 23 mm de diâmetro e 24 mm de altura. Embora as dimensões dos 
materiais fossem muito próximas, as propriedades físicas de cada um mostraram-se muito diferentes. Essas caracteísticas distintas, mostradas na Tabela 4.5 foram determinadas por meio de caracterização dos materiais realizada no Instituto de Química de São Carlos (IQSC) usando o Analisador de Sorção de Gás de Alta Velocidade da Quantachrome instruments ${ }^{\circledR}$ - Nova 1000, versão 10.02 .

Tabela 4.5 - Características físicas dos cilindros de polietileno, espuma e cerâmica.

\begin{tabular}{lccc}
\hline \multicolumn{1}{c}{ Características } & Polietileno & Material suporte & Cerâmica \\
\hline Densidade $\left(\mathrm{g} \mathrm{mL}^{-1}\right)$ & 0,9600 & 2,5000 & 0,0350 \\
Área superficial $\left(\mathrm{m}^{2}\right)$ & 4,5614 & 1,1211 & 6,6416 \\
$\begin{array}{l}\text { Área superficial específica } \\
\left(\mathrm{m}^{2} \mathrm{~g}^{-1}\right)\end{array}$ & 7,9448 & 11,7881 & 25,5759 \\
\hline
\end{tabular}

O procedimento para a determinação do volume útil dos reatores das configurações A e B foi o mesmo, e consistiu em três drenagens consecutivas dos mesmos com a zona do leito já preenchida com material suporte. A partir da somatória do volume drenado da zona de entrada, do leito e da zona de saída obteve o volume útil dos reatores, que foi, em média, 2,374 L para ambas configurações.

A porosidade do leito foi calculada a partir da razão entre o volume de líquido drenado da zona do leito preenchida com material suporte e o volume de líquido drenado da zona do leito sem preenchimento.

Os reatores de leito fixo empacotado com aproximadamente 740 g de material suporte cada um, apresentaram porosidade inicial (ع) de aproximadamente 55\%, enquanto a porosidade do leito dos reatores com leito estruturado foi de $58 \%$, em média. 


\subsection{2 - Reatores em batelada}

Os reatores em batelada foram monitorados devido a necessidade de estudar efluentes industriais como co-substratos para a produção de hidrogênio e metano a partir de esgoto sanitário.

Para os ensaios em batelada foram utilizados frascos (Duran ${ }^{\circledR}$ ) de 2 L, sendo que $1 \mathrm{~L}$ foi usado como volume reacional e $1 \mathrm{~L}$ foi destinado para o headspace.

\section{2 - Substrato}

\subsection{1 - Esgoto sanitário}

O esgoto sanitário dos bairros no entorno da USP - São Carlos - área 2 foi usado como substrato para a produção de hidrogênio e metano.

A caracterização deste esgoto com parâmetros determinados por meio dos valores médios diários é apresentada na Tabela 4.6.

Para disponibilizar o esgoto para o sistema de captação dos reatores deste projeto e dos demais trabalhos que usaram a mesma água residuária, foi construído um reservatório de $18 \mathrm{~m}^{3}$ para o qual foi desviado o esgoto da rede coletora municipal. A partir deste reservatório, um sistema de bombeamento captou o esgoto e o conduziu até um pequeno tanque de 30 litros em constante renovação, de onde a bomba do reator retirou a vazão necessária para alimentar os sistemas. 


\subsection{2 - Águas residuárias}

Três águas residuárias industriais, o próprio esgoto sanitário e mais uma solução de sacarose como substrato controle, foram usadas na avaliação da produção sequencial de hidrogênio e metano.

A vinhaça e o glicerol, subprodutos das indústrias de etanol e biodiesel, foram obtidos da usina de produção de álcool Nova Era, Ibaté, SP e da planta de produção de biodiesel Granol, Anápolis, GO, respectivamente.

A água residuária resultante da produção de arroz parboilizado foi obtida como efluente da indústria alimentícia Nelson Wendt Alimentos, Pelotas, RS.

O meio sintético tendo sacarose como fonte de carbono foi utilizado como substrato controle. A sacarose originou-se da produção de açúcar demerara pela Native Natural Products, São Francisco S/A, Sertãozinho, SP.

As características básicas de todos os substratos usados para a produção de hidrogênio e metano neste trabalho, incluindo os efluentes industriais, a solução de sacarose e o esgoto sanitário encontram-se discriminadas na Tabela 4.6.

Tabela 4.6 - Caracterização do esgoto sanitário, dos efluentes industriais e do substrato controle.

\begin{tabular}{|c|c|c|c|c|c|}
\hline Parâmetros / Substatos & Esgoto & Vinhaça & Glicerol & A.R Arroz & Sacarose \\
\hline$\overline{\mathrm{DQO}}\left(\mathrm{mg} \mathrm{L}^{-1}\right)$ & 262,3 & 20731,7 & 1108230* & 5354,1 & 357,5 \\
\hline $\mathrm{pH}$ & 6,9 & 3,8 & ND & 4,6 & 5,5 \\
\hline Alcalinidade (mg L ${ }^{-1}$ & 124 & 0 & ND & 0 & 0 \\
\hline \multicolumn{6}{|l|}{$\left.\mathrm{CaCO}_{3}\right)$} \\
\hline $\mathrm{ST}\left(\mathrm{mg} \mathrm{L}^{-1}\right)$ & 197,2 & 18170,5 & ND & 657,7 & ND \\
\hline $\operatorname{SSV}\left(\mathrm{mg} \mathrm{L}^{-1}\right)$ & 161,1 & 14440,1 & ND & 537,5 & ND \\
\hline $\mathrm{SF}\left(\mathrm{mg} \mathrm{L}^{-1}\right)$ & 359,1 & 3270,4 & ND & 119,2 & ND \\
\hline $\mathrm{N}$ Total $\left(\mathrm{mg} \mathrm{L}^{-1} \mathrm{~N}\right)$ & 42,6 & 187,5 & 0 & 104,6 & 0 \\
\hline $\mathrm{P}$ Total (mg L-1 $\left.\mathrm{PO}_{4}{ }^{3-}\right)$ & 4,7 & 133,4 & 0 & 124,5 & 0 \\
\hline
\end{tabular}


É importante frisar que a todos os frascos foi adicionado o meio de nutrientes mostrado na Tabela 4.7, afim de que houvesse as mesmas condições para o desenvolvimento dos microrganismos acidogênicos e metanogênicos em todos os substratos.

Vale acrescentar que esse meio de nutrientes foi anteriormente utilizado, com bons resultados, nos trabalhos de Fernandes et al. (2010) e Peixoto et al. (2011).

Tabela 4.7 - Composição do meio utilizado nos ensaios em reatores em batelada.

\begin{tabular}{|c|c|}
\hline Composto & Concentração (mg L $\left.{ }^{-1}\right)$ \\
\hline $\mathrm{CH}_{4} \mathrm{~N}_{2} \mathrm{O}$ & 6,0000 \\
\hline $\mathrm{NiSO}_{4} \cdot 6 \mathrm{H}_{2} \mathrm{O}$ & 0,1500 \\
\hline $\mathrm{FeSO}_{4} \cdot 7 \mathrm{H}_{2} \mathrm{O}$ & 0,7500 \\
\hline $\mathrm{FeCl}_{3} \cdot 6 \mathrm{H}_{2} \mathrm{O}$ & 0,0750 \\
\hline $\mathrm{CoCl}_{2} \cdot 2 \mathrm{H}_{2} \mathrm{O}$ & 0,0120 \\
\hline $\mathrm{CaCl}_{2} \cdot 6 \mathrm{H}_{2} \mathrm{O}$ & 0,6180 \\
\hline $\mathrm{SeO}_{2}$ & 0,0108 \\
\hline $\mathrm{KH}_{2} \mathrm{PO}_{4}$ & 1,6080 \\
\hline $\mathrm{KHPO}_{4}$ & 0,3900 \\
\hline $\mathrm{Na}_{2} \mathrm{HPO}_{4} \cdot 2 \mathrm{H}_{2} \mathrm{O}$ & 0,8280 \\
\hline
\end{tabular}

\section{3 - Inóculos}

Todos os reatores contínuos usados no experimento tiveram sua biomassa ativa gerada por meio de fermentação natural do meio conforme descrito por Rojas (2010).

O inóculo acidogênico usado nos experimentos em batelada foi gerado em etapa preliminar à utilização neste trabalho. Cerca de 60 dias antes do início da fase experimental, um reator anaeróbio de leito fixo e fluxo ascendente usando sacarose para produzir hidrogênio, foi operado por 28 dias com a finalidade de produção de biomassa. 
O reator utilizado teve as mesmas dimensões e configuração do reator tipo A, incluindo aparas de polietileno de baixa densidade na mesma granulometria determinada na fase de caracterização do suporte usado neste trabalho. Foi possível obter aproximadamente 2 litros de lodo anaeróbio com a relação Carbono/Nitrogênio de 40, na qual há a maior velocidade de acúmulo de biomassa (Rojas, 2010).

É importante ressaltar que o mesmo procedimento foi realizado por Fernandes et al. (2010) na produção de inóculo para experimentos em batelada.

O lodo gerado foi acondicionado em geladeira e mantido a $4{ }^{\circ} \mathrm{C}$ até o início dos experimentos.

O inóculo metanogênico adquirido 20 dias antes do início dos experimentos em batelada originou-se de um reator de manta de lodo e fluxo ascendente (UASB), tratando água residuária de abatedouro de aves na Avícola Dacar S.A., Tietê, SP.

Esse lodo foi anteriormente usado com bons resultados nos trabalhos de Vich (2006), Sarti (2007) e Damasceno (2008), que foram desenvolvidos no Laboratório de Processos Biológicos (LPB) SHS-EESC-USP.

\section{4 - Métodos Analíticos}

As análises de matéria orgânica (em termos de DQO), pH e sólidos (totais e em suspensão, voláteis e não voláteis) no afluente e efluente aos sistemas foram realizadas de acordo com o Standard Methods for the Examination of Water and Wastewater (2005).

Os métodos analíticos utilizados corresponderam às seguintes metodologias: 
(i) Concentração de matéria orgânica (medida como DQO) para as amostras filtradas (CSF) e não filtradas (CST) - método 5220 D (Colorimétrico - Refluxo Fechado);

(ii) $\mathrm{pH}$ - método 4500- $\mathrm{H}^{+} \mathrm{B}$ (Eletrométrico);

(iii) Sólidos totais e suspensos totais, voláteis e não voláteis (ST, SST, SVT, SSV) métodos 2540 B (Sólidos Totais Secos a 103-105 ㄷ), 2540 D (Sólidos Suspensos Totais Secos a $103-105{ }^{\circ} \mathrm{C}$ ) e 2540 E (Sólidos Fixos e Voláteis a $550{ }^{\circ} \mathrm{C}$ );

(iv) Quantificação da biomassa aderida nos reatores de leito estruturado;

As concentrações de sólidos totais (ST) e sólidos voláteis totais (SVT) presentes nos leitos estruturados foram determinadas ao final da etapa operacional com diferentes suportes. Dessa maneira, foi possível fazer uma estimativa da concentração de biomassa dentro do reator. A análise foi realizada seguindo o método 2540 B complementado com o seguinte procedimento:

a) Após a finalização da operação, à meia altura do leito dos reatores, foram retirados três cilindros de suporte para a determinação da concentração de biomassa aderida ao material. Para essa determinação, as amostras do material foram acondicionadas em frascos de plástico com $5 \mathrm{~mL}$ de água destilada junto com pérolas de vidro. Submeteu-se os frascos à agitação mecânica por 30 minutos afim de que a biomassa fosse removida mecanicamente por meio do atrito com as pérolas de vidro. Os frascos foram abertos após o período de agitação e os $5 \mathrm{~mL}$ de água destilada 
juntamente com os sólidos desprendidos foram submetidos ao procedimento descrito nos itens "b" e “c”;

b) O passo seguinte foi recolher a mistura de sólidos com água destilada em cápsulas de porcelana de $50 \mathrm{~mL}$, previamente pesadas (m $\mathrm{m}_{\text {cápsula }}$ ), e em seguida levou-se à estufa $\left(105^{\circ} \mathrm{C}, 24\right.$ horas) para a determinação da massa de sólidos totais $\left(\mathrm{m}_{\mathrm{ST}}\right)$, segundo a Equação 4.1:

$\mathrm{m}_{\mathrm{ST}}=\mathrm{m}_{105^{\circ} \mathrm{C}}-\mathrm{m}_{\text {cápsula }}$

c) Após a determinação da massa de sólidos totais, a cápsula foi colocada na mufla, mantida a $550^{\circ} \mathrm{C}$, por um período de 2 h. Passado este período, a cápsula foi novamente pesada (após resfriamento em dessecador) para obtenção da massa de sólidos totais fixos ( $\left.\mathrm{m}_{\mathrm{STF}}\right)$, segundo a Equação 4.2:

$\mathrm{m}_{\mathrm{STF}}=\mathrm{m}_{550^{\circ} \mathrm{C}}-\mathrm{m}_{\text {seca }}$ Equação 4.2

A diferença entre a massa de sólidos totais $\left(\mathrm{m}_{\mathrm{ST}}\right)$ e a massa de sólidos totais fixos ( $\left.\mathrm{m}_{\mathrm{STF}}\right)$ forneceu a massa de sólidos totais voláteis ( $\left.\mathrm{m}_{\mathrm{STV}}\right)$, conforme a Equação 4.3:

$\mathrm{m}_{\mathrm{STV}}=\mathrm{m}_{\mathrm{ST}}-\mathrm{m}_{\mathrm{STF}}$ Equação 4.3 
Desta forma pôde ser obtida a concentração de biomassa por suporte, ou seja, uma estimativa da massa de microrganismos que se desenvolveu em cada material.

Os demais parâmetros e respectivos métodos de análise foram:

\section{(i) Carboidratos:}

Medidas de carboidratos no afluente e efluente aos sistemas foram realizadas pelo método colorimétrico desenvolvido por Dubois et al. (1956), que mede a concentração de carboidratos em temos de $\mathrm{mg} \mathrm{L}^{-1}$ de carboidratos totais. O equipamento utilizado para a medição da absorbância das amostras de carboidratos foi o espectrofotômetro HACH modelo DR-2500, operado a 480 nm.

(ii) Alcalinidade a bicarbonato e ácidos voláteis medidos como ácido acético:

Medidas de alcalinidade total, parcial, intermediária e a bicarbonato (AT, AP, AI e AB), bem como de ácidos voláteis totais (AVT), foram realizadas seguindo o método titulométrico desenvolvido por Dilallo \& Albertson (1961) e, posteriormente, modificado por Ripley et al. (1986).

(iii) Ácidos orgânicos voláteis:

As análises para a detecção dos ácidos acético, butírico, cítrico, fórmico, isobutírico, isovalérico, lático e propiônico foram realizadas por Cromatografia Líquida de Alta Eficiência (CLAE) no sistema Shimadzu ${ }^{\circledR}$, constituído dos seguintes equipamentos: bomba LC-10ADvp, válvula solenóide FCV-10ALvp, forno CTO10Avp, controlador SCL-10Avp e detector UV com arranjo de diodos SPDM10Avp, 
seguindo metodologia desenvolvida no Laboratório de Processos Biológicos. As condições para as análises cromatográficas foram as seguintes:

- Coluna de troca iônica: Aminex ${ }^{\circledR}$ HPX-87H (comprimento de 0,3m, diâmetro interno de 7,8 mm);

- Fase móvel: $\mathrm{H}_{2} \mathrm{SO}_{4} 0,005 \mathrm{M}$;

- Fluxo: 0,6 mL $\min ^{1}$;

- Detector de UV: Arranjo de diodos 205 nm;

- Volume de amostra: $100 \mu \mathrm{L}$;

O programa de temperatura do forno foi o seguinte:

- Temperatura de trabalho: $45^{\circ} \mathrm{C}$;

- Temperatura máxima de trabalho: $50{ }^{\circ} \mathrm{C}$;

(iv) Álcoois e cetona:

Para a análise de álcoois (metanol, etanol e n-butanol) e cetona, foi empregado o cromatógrafo Shimadzu ${ }^{\circledR}$ GC-2010 com módulo AOC-5000 (análise de headspace), seguindo metodologia desenvolvida no Laboratório de Processos Biológicos. As condições para as análises cromatográficas foram as seguintes:

- Coluna capilar: Innowax (comprimento de 30m, diâmetro interno 0,25 mm e espessura da coluna $0,25 \mu \mathrm{m})$;

- Temperatura da coluna: $35^{\circ} \mathrm{C}$; 
- Temperatura máxima da coluna: $250{ }^{\circ} \mathrm{C}$;

- Temperatura do injetor: $250{ }^{\circ} \mathrm{C}$;

- Controle de fluxo: velocidade linear;

- Pressão: 59,3 kPa;

- Fluxo total: 6,1 mL $\min ^{-1}$;

- Fluxo na coluna: 1,56 mL $\min ^{-1}$;

- Velocidade linear: 41,8 $\mathrm{cm} \mathrm{s}^{-1}$;

- Fluxo de purge: 3,0 mL $\mathrm{min}^{-1}$;

- Detector: FID;

- Fluxo de ar: $300 \mathrm{~mL} \mathrm{~min}{ }^{-1}$;

- Temperatura: $280{ }^{\circ} \mathrm{C}$;

- Fluxo de $\mathrm{H}_{2}$ : 30,0 mL $\mathrm{min}^{-1}$;

- Gás de makeup: Nitrogênio/Ar sintético;

- Fluxo do gás de makeup: 30,0 mL min ${ }^{-1}$;

- Volume de amostra injetada: $400 \mu \mathrm{L}$;

• Tempo de análise: 14,49 minutos;

- Temperatura de incubação: $100{ }^{\circ} \mathrm{C}$;

- Tempo de incubação: 13 minutos;

- Temperatura da seringa: $90{ }^{\circ} \mathrm{C}$;

- Tempo de corrida: 24 minutos;

O programa de temperatura utilizado foi:

- Temperatura inicial: $35^{\circ} \mathrm{C}$ (2 min); 
- $1^{\text {a }}$ Taxa de aquecimento: $2^{\circ} \mathrm{C} \min ^{-1}$ até $38^{\circ} \mathrm{C}$;

- $2^{\mathrm{a}}$ Taxa de aquecimento: $10{ }^{\circ} \mathrm{C} \mathrm{min}^{-1}$ até $75^{\circ} \mathrm{C}$;

- $3^{\mathrm{a}}$ Taxa de aquecimento: $40{ }^{\circ} \mathrm{C} \min ^{-1}$ até $170{ }^{\circ} \mathrm{C}$;

- Temperatura final: $170{ }^{\circ} \mathrm{C}(5 \mathrm{~min})$;

(v) Composição do biogás:

Análises para detecção de $\mathrm{H}_{2}, \mathrm{CO}_{2}$ e $\mathrm{CH}_{4}$ no biogás foram realizadas em cromatógrafo Shimadzu ${ }^{\circledR}$ GC 2010, a partir de metodologia proposta e desenvolvida no Laboratório de Processos Biológicos.

A coleta do biogás nos reatores em batelada e contínuos foi feita por meio de seringa para cromatografia com volume total de $250 \mu \mathrm{L}$.

As condições para as análises cromatográficas foram as seguintes:

- Coluna capilar: Carboxen 1010 - (comprimento de 30m, diâmetro interno 0,53 mm e espessura da coluna $0,30 \mu \mathrm{m})$;

- Gás de arraste: Argônio;

- Temperatura inicial do injetor: $200{ }^{\circ} \mathrm{C}$;

- Temperatura inicial do detector: $230{ }^{\circ} \mathrm{C}$;

- Vazão do gás de make up (Ar): $12 \mathrm{~mL}$ minn $^{-1}$;

• Detector: condutividade térmica;

- Volume de amostra: $100 \mu \mathrm{L}$

O programa de temperatura do forno foi:

- Temperatura inicial: $40^{\circ} \mathrm{C}$ (2 min); 
- $1^{\text {a }}$ Taxa de aquecimento: $5{ }^{\circ} \mathrm{C} \min ^{-1}$ até $60{ }^{\circ} \mathrm{C}$;

- $2^{\mathrm{a}}$ Taxa de aquecimento: $25^{\circ} \mathrm{C} \min ^{-1}$ até $95^{\circ} \mathrm{C}$;

- Temperatura final: $95^{\circ} \mathrm{C}(5 \mathrm{~min})$;

A análise para detecção de $\mathrm{H}_{2} \mathrm{~S}$ foi realizada com equipamento de medição de gases no ambiente Riken Keiki ${ }^{\circledR}$ GX-2009, capaz de detectar $\mathrm{H}_{2}, \mathrm{CO}, \mathrm{CO}_{2}$ e $\mathrm{H}_{2} \mathrm{~S}$ no ar.

A pressão no interior dos reatores em batelada foi determinada por um medidor portátil Desin Instruments ${ }^{\circledR}$ TPR-18 acoplado a uma interface BS 2200 com faixa de detecção entre 0 e 500 mbar.

\section{5 - Medição da vazão volumétrica do biogás}

A quantificação do volume de biogás produzido foi realizada por meio de medidor on-line de gás tipo TG1 (milligasCounter, Ritter ${ }^{\circledR}$ ), que funciona a partir de deslocamento de líquido. O equipamento ficou permanentemente acoplado aos reatores contínuos durante os períodos de operação.

\section{6 - Estudos hidrodinâmicos nos reatores de leito fixo com diferentes arranjos e materiais suporte}


Foram realizados ensaios hidrodinâmicos nos reatores de leito fixo com a finalidade de avaliar parâmetros relacionados ao tipo de escoamento e determinar o tempo de detenção hidráulica real aplicado aos sistemas.

O traçador utilizado nos ensaios foi o cloreto de sódio ( $\mathrm{NaCl}$ ) na concentração de $10 \mathrm{~g} \mathrm{~L}^{-1}$ aplicado ao reator na forma de estímulo degrau (Levenspiel, 2000).

O procedimento consistiu em instalar, na saída do efluente líquido do reator, um vertedor com uma sonda para detecção de condutividade, acoplada a um transdutor CBL da Texas Instruments ${ }^{\circledR}$, que por sua vez foi acoplado a uma calculadora Texas TI-89®. Os sinais foram interpretados pela calculadora por cerca de 3 vezes o tempo de detenção hidráulica teórico.

Por meio da calculadora foram obtidos os dados experimentais da curva C (Concentração x Tempo) e com o auxílio do programa Microcal Origin 6.0® foram calculadas as curvas F (Equação 4.4) e curvas E (Equação 4.5). Já o TDH médio foi determinado de acordo com a Equação 4.6 (Levenspiel, 2000).

$F=\frac{C}{C_{\max }}$ Equação

$4.4 E=\frac{d F}{d t}$ Equação 4.5

$\theta h=\frac{\int_{0}^{\infty} t \cdot C(t) \cdot d t}{\int_{0}^{\infty} C(t) \cdot d t}$ 
Na equação (4.6), Oh é o TDH médio, C a concentração do traçador e t o tempo.

A variância $\left(\sigma^{2}\right)$ das curvas, que indica a dispersão da distribuição, foi calculada com a Equação 4.7 (Levenspiel, 2000):

$$
\sigma^{2}=\frac{\int_{0}^{\infty}(t-\bar{\theta} h)^{2} \cdot C(t) \cdot d t}{\int_{0}^{\infty} C(t) \cdot d t}
$$

A partir do cálculo da variância adimensional (Equação 4.8), foi obtido o número de dispersão ( $D$ / $\mu . L$ ) das curvas por meio das Equação 4.9 para dispersões de pequena intensidade segundo Levenspiel (2000).

$$
\begin{aligned}
& \sigma_{\theta}^{2}=\frac{\sigma^{2}}{\bar{\theta} h^{2}} \\
& \sigma_{\theta}^{2}=2\left[\frac{D}{\mu \cdot L}\right]
\end{aligned}
$$

Para a caracterizacao do tipo de escoamento utilizou-se no modelo de tanques de mistura completa em série e calculou-se o número de reatores $(\mathrm{N})$ a partir da Equação 4.10 (Levenspiel, 2000):

$$
\sigma_{\theta}^{2}=\frac{1}{N}
$$




\section{7 - Estudos cinéticos nos reatores em batelada com diferentes substratos}

Foram realizados estudos cinéticos como forma de analisar o desempenho de diferentes substratos na produção sequencial de hidrogênio e metano, já que o esgoto sanitário poderia demandar suplementação com algum co-substrato para que houvesse producao de $\mathrm{H}_{2}$.

A equação modificada de Gompertz (Zwietering et al., 1990) [Equação (4.11)] foi usada para descrever as curvas de produção de hidrogênio de cada um dos reatores em batelada.

$$
H(t)=P \exp \left\{-\exp \left[\frac{R_{m} \cdot e}{P} \cdot(\lambda-t)+1\right]\right\}
$$

Na Equação (4.11), H é a produção cumulativa de hidrogênio (mL), $\lambda$ é o tempo de fase lag (h), P é o potencial de produção de hidrogênio $(m L), R_{m}$ é a velocidade de produção de hidrogênio $\left(\mathrm{mL} \mathrm{h}^{-1}\right), t$ é o tempo de incubação (h), e $e$ é o número de Euler (2.71828).

Os parâmetros (P, $\mathrm{R}_{\mathrm{m}}$ e $\lambda$ ) foram estimados com o programa STATISTICA ${ }^{\circledR}$ 8.0.360. (Statsoft, Inc. Tulsa, Oklahoma) usando o algoritmo de Newton-Gauss. Aproximadamente cem iterações foram realizadas para que os valores previstos pelo modelo de Gompertz convergissem os resultados experimentais. O rendimento de hidrogênio ( $\left.\mathrm{Y}_{\mathrm{H} 2}\right)$ foi calculado como a razão entre o volume de hidrogênio $\left(\mathrm{mL} \mathrm{H}_{2}\right)$ e a concentração inicial de matéria-orgânica dos substratos em termos de concentração inicial de DQO (g L ${ }^{-1}$ de demanda química de oxigênio). 
A velocidade específica de produção de hidrogênio, $\mathrm{R}_{\mathrm{S}}\left(\mathrm{mL} \mathrm{H}_{2} \mathrm{~h}^{-1} \mathrm{~g}^{-1} \mathrm{SSV}\right)$, foi obtida dividindo-se $R_{m}$ pelo resultado dos sólidos suspensos voláteis (SSV) que foram adicionados ao reator. A eficiência de conversão de hidrogênio para diferentes substratos foi comparada com base nos parâmetros $\mathrm{Y}_{\mathrm{H} 2}$ e $\mathrm{R}_{\mathrm{s}}$.

Com relação à produção de metano, o modelo de cinética de primeira ordem descrito por Borja et al. (1995) foi usado para ajustar os dados experimentais. De acordo com esse modelo, o volume de metano acumulado (G) (mL, 1 atm e $\left.25{ }^{\circ} \mathrm{C}\right)$ em um dado tempo t (h) ajusta-se à seguinte equação:

$G=G_{m}\left[1-\exp \left(-K_{G}{ }_{G} . t\right)\right]$

Equação 4.12

Na Equação (4.12), $\mathrm{G}_{\mathrm{m}}$ é o volume máximo de metano acumulado em um dado tempo de disgestão; $\mathrm{G}$ é zero em $t=0$, e a velocidade de produção de biogás torna-se zero quando $t$ tende ao infinito. $\mathrm{K}_{\mathrm{G}}$ é uma constante cinética para a produção de metano $\left(\mathrm{h}^{-1}\right)$, que inclui a concentração de biomassa, conforme mostrado na Equação 4.13

$K_{G}^{\prime}=K_{G} \cdot X$ Equação 4.13

Na Equação (4.13), $K_{G}$ é a constante cinética de produção específica de metano ( $\mathrm{mL} \mathrm{CH}_{4} \mathrm{~g}^{-1} \mathrm{SSV} \mathrm{h}^{-1}$ ), e X é a concentração de biomassa (g SSV L ${ }^{-1}$ ). Os valores de $\mathrm{K}_{\mathrm{G}}$ e $\mathrm{G}_{\mathrm{m}}$ para cada substrato foram calculados numericamente a partir dos dados experimentais obtidos por regressão não-linear usando o programa Origin ${ }^{\circledR}$ 8.0891. (OriginLab, Corp. Northamptom, Massachussets). O rendimento na 
produção de metano $\left(\mathrm{Y}_{\mathrm{CH} 4}\right)$ foi calculado como uma razão entre o volume de metano ( $\left.\mathrm{mL} \mathrm{CH}_{4}\right)$ e a concentração inicial de matéria orgânica dos substratos, que foi medida em termos de concentração de DQO (g L ${ }^{-1}$ de demanda química de oxigênio). A velocidade específica de produção de metano, $\mathrm{K}_{\mathrm{G}}\left(\mathrm{mL} \mathrm{CH}_{4} \mathrm{~g}^{-1} \mathrm{SSV} \mathrm{h}^{-1}\right)$, foi obtida por meio da Equação 4.13.

Os resultados de remoção de DQO e consumo de carboidratos foram ajustados considerando a cinética de uma reação de primeira ordem conforme descrito pelas equações cinéticas 4.14 e 4.15 .

$-\frac{d C_{C O D}}{d t}=k_{1} C_{C O D}$ Equação 4.14

$-\frac{d C_{C}}{d t}=k_{2} C_{C}$ Equação 4.15

Nas Equações 4.14 e 4.15, $C_{D Q O}$ é a concentração medida em termos de demanda química de oxigênio, $C_{C}$ é a concentração de carboidratos, $k_{1}$ é a constante de reação de primeira ordem para a DQO, $k_{2}$ é a constante de reação de primeira ordem para os carboidratos, e $t$ é o tempo.

\section{8 - Exames Microbiológicos}

\subsection{1 - Microscopia}


As amostras de biomassa foram examinadas sob luz comum e com fluorescência. Uma gota de amostra foi colocada sob fina camada de gel agar para diminuir a movimentação e facilitar a visualização das células.

Foi utilizado o Microscópio Leica ${ }^{\circledR}$ DM LB com câmera de captura para o programa Image Pro Plus ${ }^{\circledR}$ versão 4.5.0.19.

\section{9 - Procedimento Experimental}

O Fluxograma apresentado na Figura 4.7 mostra as etapas envolvidas neste trabalho, as quais são detalhadamente descritas nos ítens 4.9.1 à 4.9.6. 


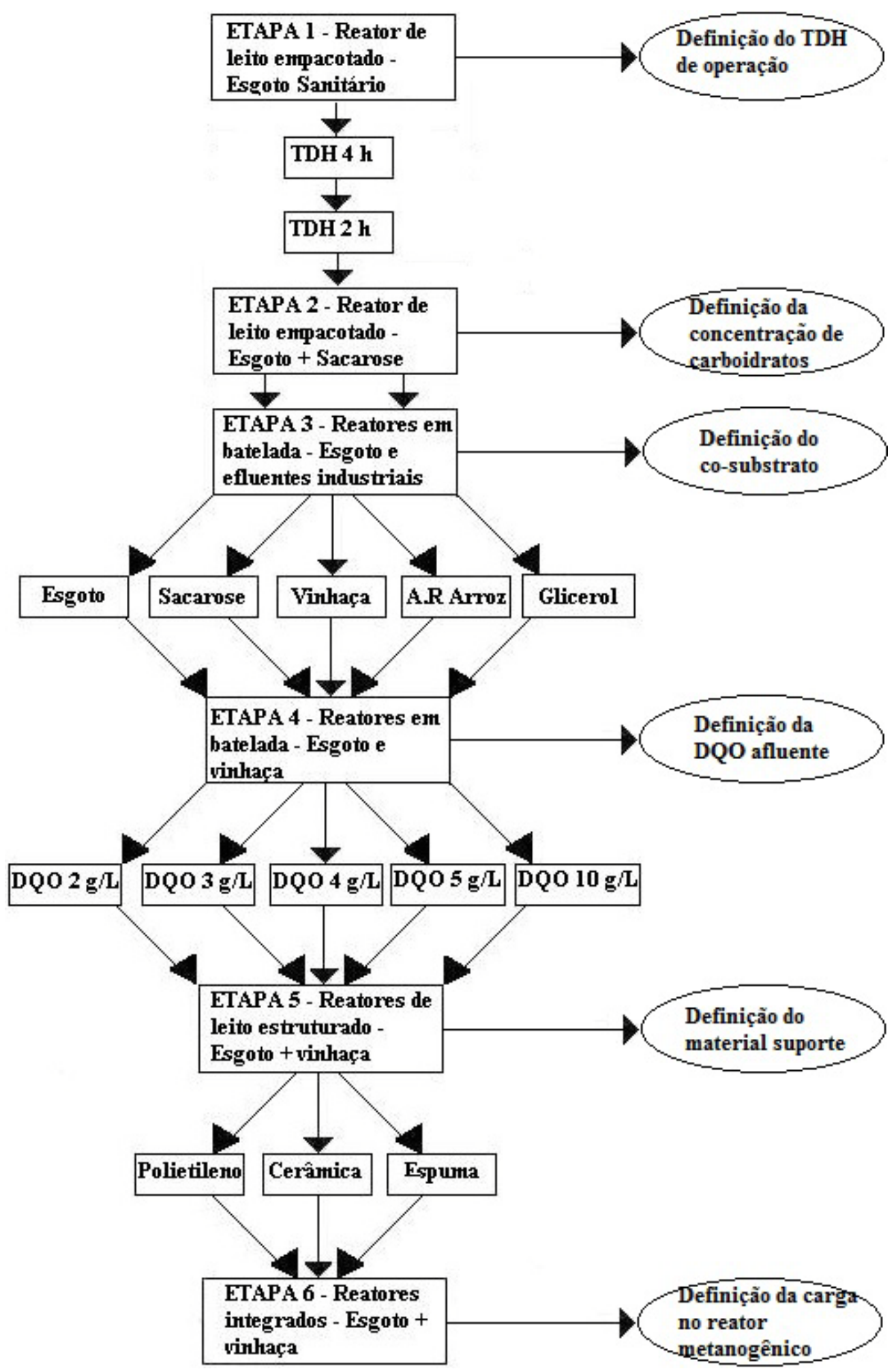

Figura 4.7 - Fluxograma das etapas envolvidas na fase experimental. 


\subsection{1 - Etapa 1}

O objetivo desta etapa foi avaliar o efeito da aplicação dos TDHs de 4 h e 2 h sobre a produção de hidrogênio a partir de esgoto sanitário em um reator anaeróbio com leito empacotado constituído por aparas de polietileno de baixa densidade e fluxo ascendente, conforme descrito como “configuração A” no ítem 4.1.1 deste Capítulo.

O Fluxograma apresentado na Figura 4.8 ilustra as fases descritas no experimento desta Etapa.

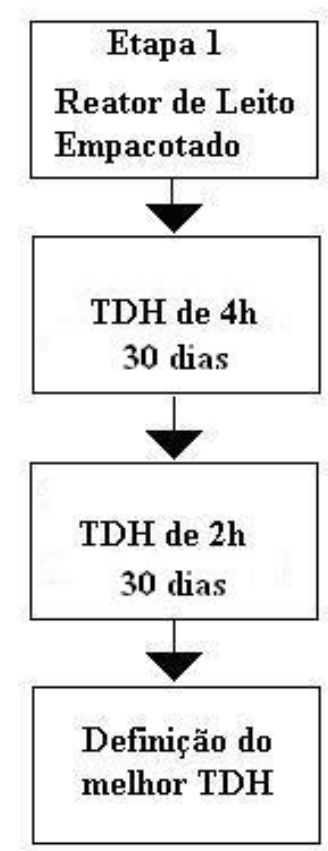

Figura 4.8 - Fluxograma do procedimento adotado na Etapa 1.

A inoculação do reator consistiu em preparar cerca de $30 \mathrm{~L}$ de substrato contendo $1,8 \mathrm{~g} \mathrm{~L}^{-1}$ de sacarose mais o meio de nutrientes usado por Rojas (2010). Foi empregada a concentração de $46 \mathrm{mg} \mathrm{L}^{-1}$ de uréia para a obtenção de uma relação C/N de 40, a qual favoreceu maior acúmulo de biomassa acidogênica intersticial (Rojas, 
2010), pois buscava-se o máximo de adesão de biomassa acidogênica nos suportes para facilitar a degradação do esgoto sanitário, quando o mesmo passasse a ser bombeado para o reator.

Seguindo o protocolo descrito por Rojas (2010), o substrato permaneceu em contato com a atmosfera por 3 dias até que houvesse a fermentação natural e depois a biomassa gerada foi imobilizada por meio da recirculação por 5 dias no reator, visando sua adesão no material suporte, o que constituiu, em grande parte, o procedimento inicialmente proposto por Leite et al. (2008).

Depois desse procedimento, o resíduo da fermentação foi descartado e o reator passou a ser alimentado com esgoto sanitário a um TDH de 4 h por 30 dias, reduzido posteriormente para um TDH de 2 h por mais 30 dias, totalizando os 60 dias de operação.

O reator foi operado com porosidade inicial de leito de 55\% em câmara termostática mantida a $25 \pm 2{ }^{\circ} \mathrm{C}$. Os parametros de controle e as variáveis que foram monitoradas são apresentadas na Tabela 4.8.

Tabela 4.8 - Parâmetros de controle e variáveis monitoradas na Etapa 1.

\begin{tabular}{lll}
\hline \multicolumn{1}{c}{ Variável } & \multicolumn{1}{c}{ Método } & Frequência \\
\hline Vazão & Proveta e cronômetro & 3 x Semana \\
Temperatura & Termômetro da câmara & 3 x Semana \\
DQO filtrada $\left(\mathrm{mg} \mathrm{L}^{-1}\right)$ & Espectrofotométrico & 2 x Semana \\
pH & Potenciométrico & 3 x Semana \\
Ácidos voláteis & Titulométrico & 2 x Semana \\
Alcalinidade & Titulométrico & 2 x Semana \\
Composição do biogás & Cromatográfico & 3 x Semana \\
Volume do biogás & Deslocamento de líquido & 3 x Semana \\
Carboidratos & Espectrofotométrico & $2 \times$ Semana \\
\hline
\end{tabular}

\subsection{2 - Etapa 2}


O objetivo desta etapa foi determinar se a concentração de carboidratos no esgoto sanitário era o fator limitante para a produção de hidrogênio, e em caso positivo, verificar a concentração mínima necessária para a geração de biogás volumetricamente mensurável.

Para isso foram utilizados reatores com leito empacotado constituído por aparas de polietileno de baixa densidade e fluxo ascendente, conforme os descritos como “configuração A” no item 4.1.1 deste Capítulo.

A inoculação dos reatores seguiu o procedimento descrito na Etapa 1, utilizando inicialmente o mesmo substrato e meio de nutrientes. Porém, após os 5 dias de recirculação para adesão da biomassa, os reatores passaram a ser alimentados continuamente por mais 5 dias pelo substrato usado na fase de inoculação e não por esgoto sanitário, de forma que o comportamento dos mesmos pudesse ser analisado frente a estratégia de suplementação do esgoto por carboidratos. Essa estratégia consistiu em operar o reator R1 (TDH 1 h) e o reator R2 (TDH 2 h) por 25 dias, os quais foram divididos em 5 etapas. Na primeira etapa, os reatores foram alimentados com $100 \%$ de substrato sintético composto de $1,8 \mathrm{~g} \mathrm{~L}^{-1}$ de sacarose e na segunda, terceira, e quarta etapas com 75, 50 e $25 \%$ deste meio sintético a base de sacarose, respectivamente. Dessa forma a concentração de carboidratos na alimentação do reator foi sendo diminuída enquanto a concentração de esgoto sanitário como substrato para a produção de hidrogênio era aumentada de 25\% na segunda etapa a $100 \%$ na quinta etapa.

O fluxograma da Figura 4.9 ilustra melhor o procedimento. 


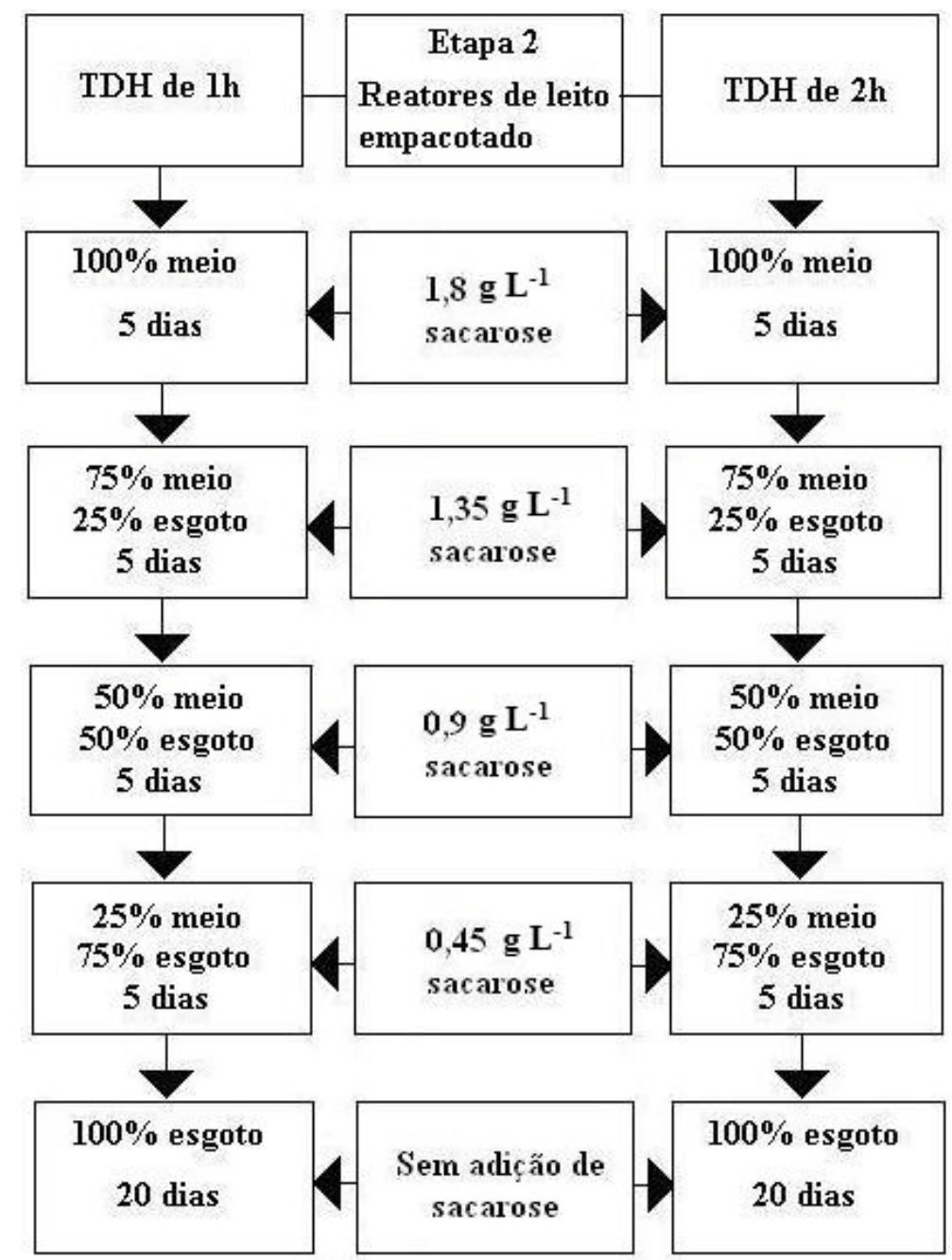

Figura 4.9 - Fluxograma do procedimento adotado na Etapa 2.

Esta estratégia foi implementada variando-se a vazão das duas correntes de alimentação de cada um dos reatores (R1 e R2). A corrente de esgoto sanitário foi mantida por bombeamento de um pequeno reservatório de esgoto em constante renovação, enquanto a corrente de solução de meio sintético a base de sacarose foi bombeada de dentro de uma geladeira mantida a $4{ }^{\circ} \mathrm{C}$.

O tempo total de operação dos reatores dessa etapa foi de 45 dias, sendo que 25 dias foram usados para as 5 etapas com variação da composição do afluente e 20 dias para a operação com 100\% de esgoto sanitário como afluente. 
Os reatores desta etapa foram operados em câmara termostática mantida a $25^{\circ} \mathrm{C}$. Os parâmetros de controle e as variáveis monitoradas são apresentadas na Tabela 4.9.

Tabela 4.9 - Parâmetros de controle e variáveis monitoradas na Etapa 2.

\begin{tabular}{lll}
\hline \multicolumn{1}{c}{ Variável } & \multicolumn{1}{c}{ Método } & Frequência \\
\hline Vazão & Proveta e cronômetro & 4 x Semana \\
Temperatura & Termômetro da câmara & 3 x Semana \\
DQO filtrada $\left(\mathrm{mg} \mathrm{L}^{-1}\right)$ & Espectrofotométrico & 4 x Semana \\
pH & Potenciométrico & 4 x Semana \\
Ácidos voláteis & Cromatográfico & 3 x Semana \\
Composição do biogás & Cromatográfico & 3 x Semana \\
Volume do biogás & Deslocamento de líquido & 3 x Semana \\
Carboidratos & Espectrofotométrico & 4 x Semana \\
\hline
\end{tabular}

\subsection{3 - Etapa 3}

O objetivo desta etapa foi avaliar, em reatores em batelada, o potencial do glicerol, da água residuária de parboilização do arroz e da vinhaça como cosubstratos do esgoto sanitário para a produção de hidrogênio num primeiro estágio e metano num segundo estágio. Sacarose e esgoto também foram avaliados, porém como substratos controle.

Os reatores em batelada foram preenchidos com os substratos filtrados em membranas de $0.45-\mu$ m e diluídos com água deionizada para que atingissem cerca de $300 \mathrm{mg} \mathrm{L}^{-1}$ DQO. A DQO foi equalizada visando posteriores análises comparativas (Fernandes et al., 2010).

O experimento foi dividido em uma fase acidogênica $(0-42$ h) e uma fase metanogênica (48-224 h). Os ensaios foram realizados em 5 reatores em batelada 
(em duplicata). Argônio foi fluxionado por 20 minutos a fim de garantir as condições anaeróbias dos frascos antes de fechá-los. Os reatores foram acondicionados na Incubadora 430 (Nova Ética ${ }^{\circledR}$ ) à $25.0 \pm 0.9{ }^{\circ} \mathrm{C}$. Amostras líquidas e gasosas foram retiradas periodicamente para as análises. A pressão interna dos frascos foi medida a cada amostragem de gás e menos de $10 \%$ do volume total da fase líquida foi retirado durante a realização do experimento.

Na fase acidogênica ( 0 a 42 h), a fase líquida (1 L) foi constituída pelos substratos diluídos e ajustados ao $\mathrm{pH}$ de 5,5 mais o meio de nutrientes apresentado no item 4.2.2 deste Capítulo e o inóculo composto de aproximadamente 400 mg SSV $\mathrm{L}^{-1}$ de biomassa acidogênica produzida em etapa preliminar, conforme descrito na seção 4.3 deste Capítulo.

Antes de iniciar a fase metanogênica (48 a 224 h), os reatores da primeira fase foram abertos e a fase líquida dos mesmos foi filtrada com uma membrana de 0.45$\mu \mathrm{m}$ para remover a biomassa acidogênica. Depois desse procedimento, o $\mathrm{pH}$ foi ajustado para 7, os frascos foram complementados com o mesmo meio de nutrients usado na primeira fase, inoculados com cerca de $500 \mathrm{mg} \mathrm{SSV} \mathrm{L}^{-1}$ de biomassa metanogênica descrita no item 4.3 deste Capítulo, fluxionados com Argônio para garantir as condições anaeróbias e fechados novamente para as análises da etapa metanogênica.

O Fluxograma apresentado na Figura 4.10 ilustra o procedimento adotado nesta etapa para a avaliação da produção sequencial de hidrogênio e metano. 
Inóculo acidogênico ( 0 a 42 h de experimento )
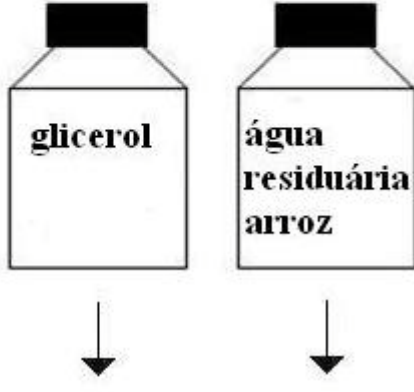

Inóculo metanogênico ( 48 a 224 h de experimento )
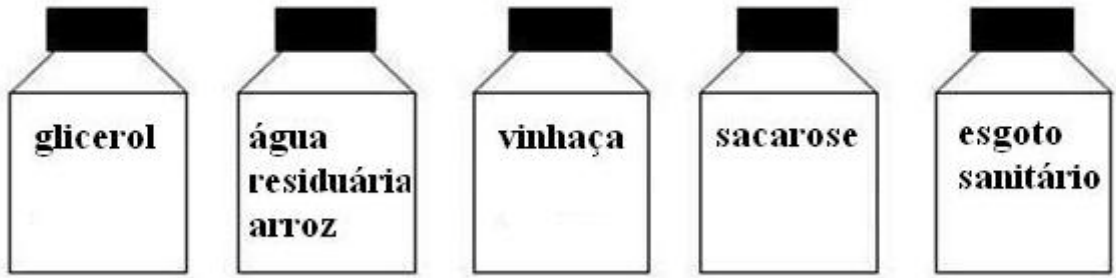

Figura 4.10 - Fluxograma do procedimento adotado na Etapa 3.

A Tabela 4.10 traz os parâmetros de controle e as variáveis monitoradas nesta etapa.

Tabela 4.10 - Parâmetros de controle e variáveis monitoradas na Etapa 3.

\begin{tabular}{ll}
\hline \multicolumn{1}{c}{ Variável } & \multicolumn{1}{c}{ Método } \\
\hline Temperatura & Termômetro da incubadora \\
Pressão & Piezoelétrico \\
DQO filtrada $\left(\mathrm{mg} \mathrm{L}^{-1}\right)$ & Espectrofotométrico \\
$\mathrm{pH}$ & Potenciométrico \\
ST, STV, SSV e SST & Gravimétrico \\
Ácidos voláteis & Cromatográfico \\
Álcoois & Cromatográfico \\
Composição do Biogás & Cromatográfico \\
Carboidratos & Espectrofotométrico \\
\hline
\end{tabular}




\subsection{4 - Etapa 4}

O objetivo desta etapa foi determinar qual seria o grau de diluição da vinhaça no esgoto sanitário com a finalidade de suplementacao do mesmo, e avaliar os efeitos dessa suplementação sobre a produção de hidrogênio.

Nesta etapa, dez reatores em batelada foram monitorados com a finalidade de avaliar a produção de hidrogênio a partir de cinco diluições de vinhaça em água deionizada e cinco diluições em esgoto sanitário. Frascos rotulados como "AV” continham água deionizada mais volumes determinados de vinhaça para a obtenção de DQO na faixa de 2000, 3000, 4000, 5000 e $10000 \mathrm{mg} \mathrm{L}^{-1}$ e outros cinco frascos Duran ${ }^{\circledR}$ de 2 litros ( 1 L de headspace e $1 \mathrm{~L}$ de meio) rotulados como "EV" tiveram esgoto sanitário adicionado de volumes de vinhaça calculados para que se atingisse concentrações de DQO correspondentes a 2000, 3000, 4000, 5000 e $10000 \mathrm{mg} \mathrm{L}^{-1}$.

Não foi adicionado meio contendo nutrientes. O único elemento adicionado foi bicarbonato de sódio para o ajuste do $\mathrm{pH}$, uma vez que abaixo de $\quad 4,7$ pode haver inibição da hidrogenase, uma das principais enzimas envolvidas na produção de hidrogênio (Lay, 2000).

O procedimento de inoculação e preparação dos frascos seguiu o protocolo descrito na seção 4.9.3 deste Capítulo. A concentração de biomassa inicial inoculada nos reatores foi de $310 \mathrm{mg} \mathrm{L}^{-1} \mathrm{SSV}$, em média, da mesma biomassa acidogênica usada para inocular os reatores no experimento da Etapa 3.

Os reatores foram mantidos em incubadora a $25 \pm 2^{\circ} \mathrm{C}$ por cerca de $96 \mathrm{~h}$, que foi o tempo total de experimento.

A Figura 4.11 demonstra como foram distribuídos os reatores com seus 
respectivos diluentes e frações de vinhaça no meio.

Reatores acidogênicos com vinhaça diluída em água deionizada
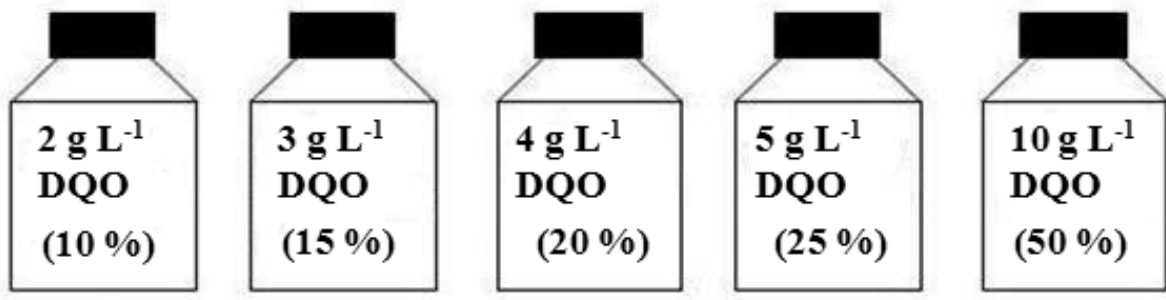

Reatores acidogênicos com vinhaça diluída em esgoto sanitário
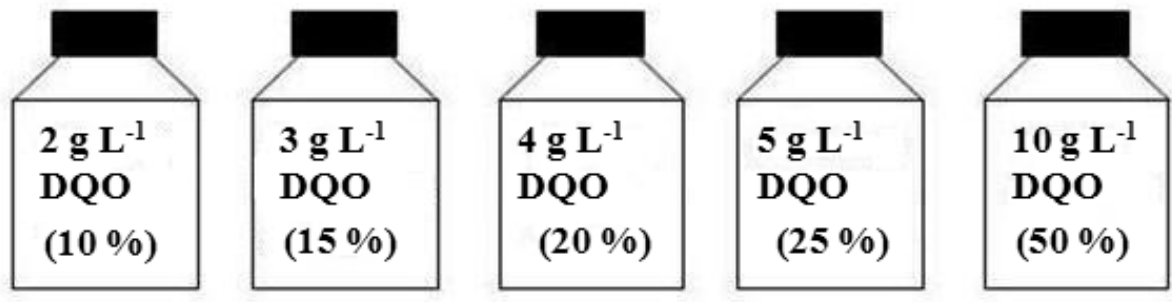

Figura 4.11 - Fluxograma do procedimento adotado na Etapa 4.

Os parâmetros de controle e as variáveis monitoradas nesta etapa são apresentadas na Tabela 4.11.

Tabela 4.11 - Parâmetros de controle e variáveis monitoradas na Etapa 4.

\begin{tabular}{ll}
\hline \multicolumn{1}{c}{ Variável } & \multicolumn{1}{c}{ Método } \\
\hline Temperatura & Termômetro \\
Pressão & Piezoelétrico \\
DQO bruta $\left(\mathrm{mg} \mathrm{L}^{-1}\right)$ & Espectrofotométrico \\
$\mathrm{pH}$ & Potenciométrico \\
Composição do biogás & Célula do GX-2009 \\
Composição do Biogás & Cromatográfico \\
ST, STV, SSV e SST & Gravimétrico \\
\hline
\end{tabular}




\subsection{5 - Etapa 5}

O objetivo desta etapa foi avaliar a produção de hidrogênio a partir de esgoto sanitário suplementado com vinhaça em reatores anaeróbios de fluxo ascendente com 3 materiais suporte diferentes, cada qual avaliado em seu respectivo reator.

Inicialmente, o comportamento hidrodinâmico da configuração de reator tipo B, ou seja, com o leito estruturado foi testada na forma dos arranjos mostrados na Figura 4.12. O primeiro, com os cilindros de material suporte empilhados continuamente nas hastes, e o segundo com os cilindros intercalados por espaços nas hastes. Dessa forma, esses dois arranjos foram denominados de leito estruturado em coluna e leito estruturado intercalado.

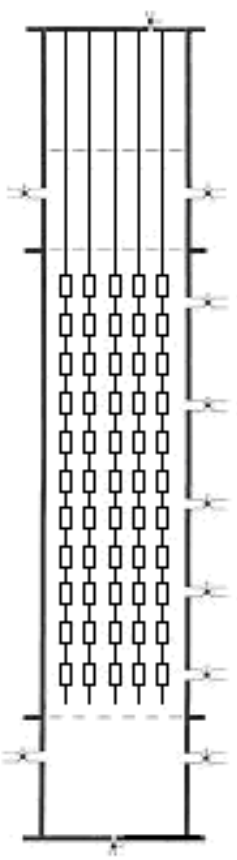

Coluna

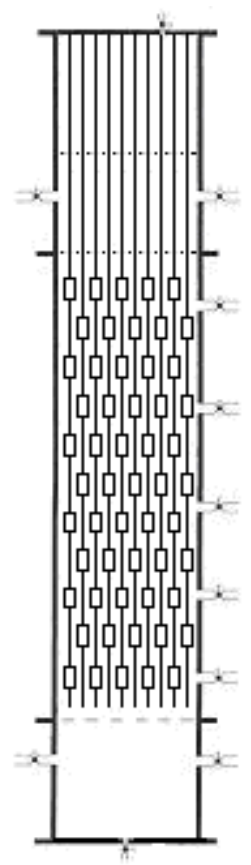

Intercalado

Figura 4.12 - Arranjo de leito estruturado em coluna e intercalado. 
O leito constituído por aparas de polietileno (distribuição aleatória) também foi avaliado, porém não como alternativa, pois já havia sido utilizado em trabalhos anteriores (Fernandes, 2008; Rojas, 2010; Peixoto et al., 2011) com indicativos de colmatação durante a operação.

Para a avaliação do comportamento hidrodinâmico das diferentes configurações de leito foram utilizados os protocolos descritos na seção 4.6 deste Capítulo.

Os ensaios hidrodinâmicos foram realizados com os materiais suporte citados na Etapa 4.1.1. deste Capitulo. Após os ensaios, que definiram a melhor configuração do leito estruturado para a operação com escoamento tipo pistão, os reatores foram inoculados usando o mesmo procedimento descrito na Etapa 1. Estes reatores foram operados com TDH de 2h, cada um com seu respectivo material suporte.

A operação dos reatores foi feita por 60 dias à $25 \pm 4{ }^{\circ} \mathrm{C}$, sendo que nesta fase os reatores foram alimentados com a mistura de esgoto sanitário e vinhaça, conforme mostra o Fluxograma da Figura 4.13.

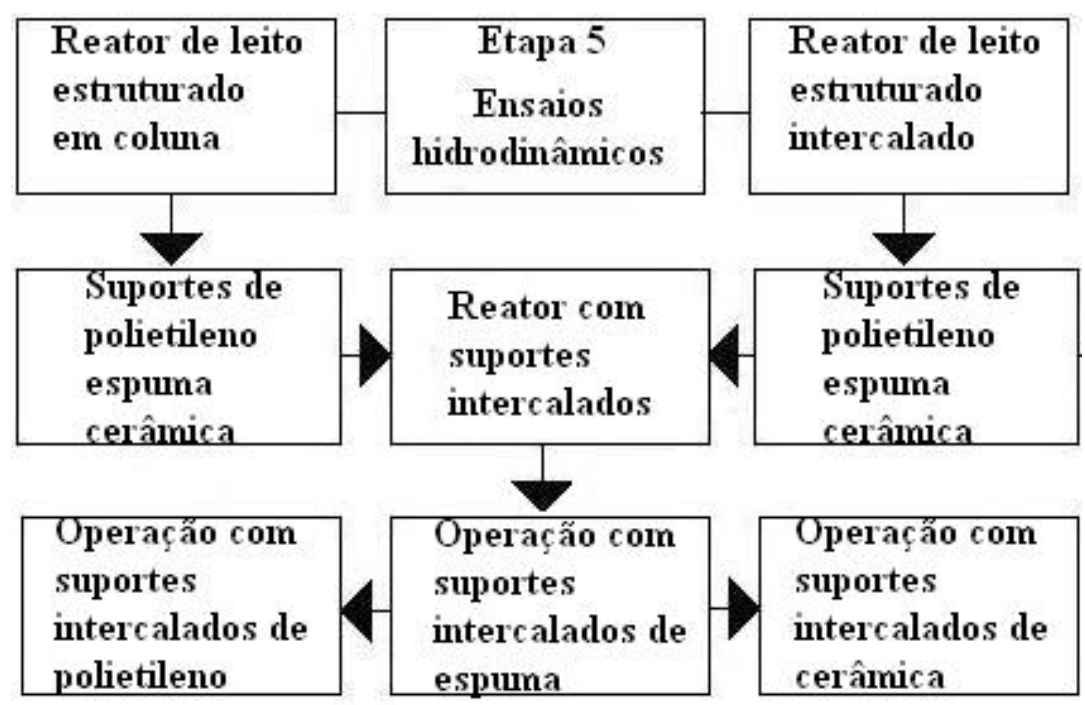

Figura 4.13 - Fluxograma do procedimento adotado na Etapa 5. 
O desempenho na operacão dos reatores com os diferentes materiais suporte foi avaliado por meio dos parâmetros e variáveis mostradas na Tabela 4.12.

Tabela 4.12 - Parâmetros de controle e variáveis monitoradas na Etapa 5.

\begin{tabular}{lll}
\hline \multicolumn{1}{c}{ Variável } & \multicolumn{1}{c}{ Método } & Frequência \\
\hline Vazão & Proveta e cronômetro & 4 x Semana \\
Temperatura & Termômetro da câmara & 4 x Semana \\
DQO filtrada $\left(\mathrm{mg} \mathrm{L}^{-1}\right)$ & Espectrofotométrico & 2 x Semana \\
pH & Potenciométrico & 3 x Semana \\
ST, STV, SSV e SST & Gravimétrico & 1 x Semana \\
Ácidos voláteis & Cromatográfico & 3 x Semana \\
Composição do Biogás & Cromatográfico & 3 x Semana \\
Composição do Biogás & Célula do GX-2009 & 2 x Semana \\
Hidrogênio & Deslocamento de líquido & 5 x Semana \\
Carboidratos & Espectrofotométrico & $3 \times$ Semana \\
\hline
\end{tabular}

\subsection{6 - Etapa 6}

O objetivo desta etapa foi verificar os efeitos da utilização do efluente de um reator acidogênico produzindo hidrogênio como substrato para um reator metanogênico, visando avaliar sua estabilidade, remoção de matéria orgânica e produção de biogás.

Inicialmente foi monitorado um reator UASB sendo alimentado por esgoto sanitário, que foi iniciado 60 dias antes desta fase experimental. O reator foi inoculado com aproximadamente 1 litro de lodo metanogênico contendo 37 g SSV L

${ }^{1}$ que foi retirado do meio da manta de lodo de um reator UASB tratando efluente de abatedouro de aves, conforme descrito na seção 4.3 deste Capítulo.

Este reator de 3,8 L mostrado em detalhes na seção 4.1.1 deste Capítulo teve 
seus parâmetros de controle e desempenho monitorados 33 dias antes da integração com o reator acidogênico.

No $23^{\circ}$ dia de monitoramento do reator UASB, foi dada a partida no reator anaeróbio de leito fixo estruturado usado para produzir hidrogênio no primeiro estágio. O procedimento de partida e a operação do reator acidogênico seguiram o protocolo definido na Etapa 1 deste Capítulo.

Essa cronologia foi adotada para que no $33^{\circ}$ dia de monitoramento do reator UASB já houvesse efluente do reator acidogênico para servir como substrato para o referido reator.

Conforme mostra o Fluxograma da Figura 4.14, o reator metanogênico (UASB) foi operado em integracao com o reator acidogenico do 33 ao $73^{\circ}$ dia de monitoramento tendo como substrato o produto da acidificação da sacarose, e do 74 ao $104^{\circ}$ dia tendo como substrato a mistura acidificada de esgoto e vinhaça.

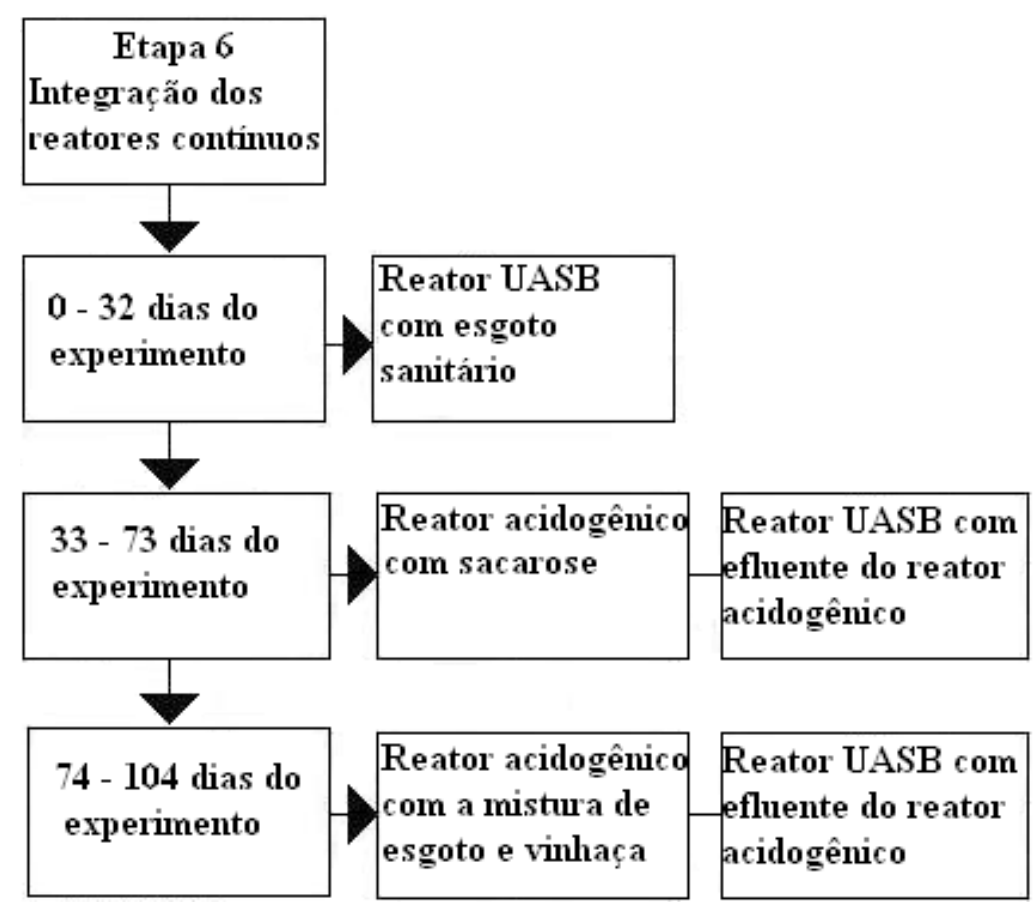

Figura 4.14 - Fluxograma do procedimento adotado na Etapa 6. 
A Figura 4.15 ilustra, em termos de fluxo, como funcionou a integração entre o reator anaeróbio de leito estruturado intercalado (produtor de H2) e o reator anaeróbio de manta de lodo (produtor de $\mathrm{CH} 4)$.

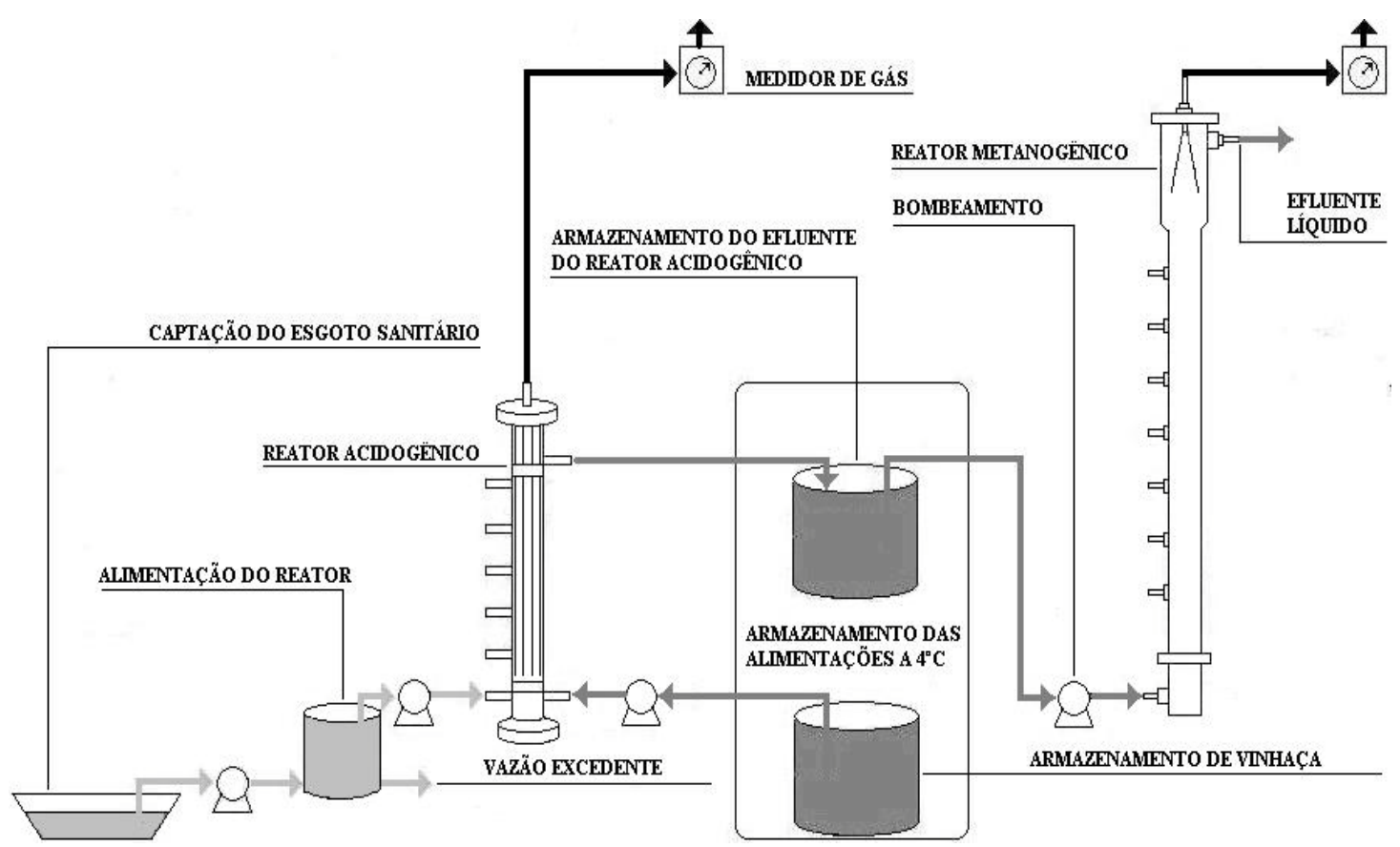

Figura 4.15 - Diagrama do funcionamento integrado dos reatores na Etapa 6.

Deve-se ressaltar que nesta etapa, assim como nas anteriores que envolveram a operação com reatores contínuos usando a mistura de esgoto sanitário e vinhaça, que o esgoto sanitário foi continuamente captado sem a necessidade de armazenamento, enquanto a vinhaça foi mantida em geladeira a $4^{\circ} \mathrm{C}$ a fim de evitar sua degradação.

Especificamente, neste último experimento envolvendo o uso do efluente do reator acidogênico como alimentação para o reator metanogênico, este substrato acidificado também foi mantido resfriado a $4^{\circ} \mathrm{C}$ para evitar possível degradação, já que a temperatura na câmara utilizada para abrigar os reatores situou-se em torno de 
$25 \pm 4^{\circ} \mathrm{C}$.

É importante frisar que antes que o substrato acificado no reator produtor de $\mathrm{H}_{2}$ fosse bombeado para o reator metanogênico, seu pH era corrigido para 7.

Devido a diferença de vazão de operação dos reatores, grande parte do efluente do reator acidogênico era descartada, pois 1 dia de geração de efluente acidogênico era capaz de suprir por 3 dias a alimentação do reator metanogênico.

Nesta última etapa, os parâmetros de controle e as variáveis monitoradas em ambos os reatores são apresentados na Tabela 4.13.

Tabela 4.13 - Parâmetros de controle e variáveis monitoradas na Etapa 6.

\begin{tabular}{lll}
\hline \multicolumn{1}{c}{ Variável } & \multicolumn{1}{c}{ Método } & Frequência \\
\hline Vazão & Proveta e cronômetro & 3 x Semana \\
Temperatura & Termômetro da câmara & 3 x Semana \\
DQO filtrada $\left(\mathrm{mg} \mathrm{L}^{-1}\right)$ & Espectrofotométrico & 3 x Semana \\
pH & Potenciométrico & 3 x Semana \\
ST, STV, SSV e SST & Gravimétrico & $3 \times$ Semana \\
Ácidos voláteis & Cromatográfico & 3 x Semana \\
Composição do Biogás & Cromatográfico & 3 x Semana \\
Hidrogênio & Deslocamento de líquido & 3 x Semana \\
Carboidratos & Espectrofotométrico & 3 x Semana \\
\hline
\end{tabular}




\section{CAPÍTULO 5}

\section{RESULTADOS E DISCUSSÃO}

Neste capítulo são apresentados e discutidos os resultados referentes às seis etapas deste trabalho. Os resultados de cada etapa serviram como fundamento para o início das etapas posteriores.

\section{1 - Etapa 1 - Avaliação do efeito do TDH sobre a produção de hidrogênio a partir de esgoto sanitário por um reator anaeróbio de fluxo ascendente com leito empacotado constituído por aparas de polietileno}

A hipótese testada nesta etapa foi a produção de hidrogênio a partir de esgoto sanitário, que sustentou-se no fato de Fernandes et al. (2010) terem alcançado a produção de $200 \mathrm{~mL} \mathrm{H}_{2} \mathrm{~g}^{-1}$ DQO a partir de esgoto sanitário em reatores em batelada.

Como o reator foi operado sem a adição de meio contendo macronutrientes, o esgoto sanitário foi caracterizado por meio de perfis temporais mostrados nas Figuras 5.1, 5.2 e 5.3 .

Dentre os perfis apresentados, o de DQO (matéria orgânica) foi realizado no dia 27/04/2009, o perfil de nitrogênio amoniacal em 09/11/2009 e o de fosfato em 02/07/2009. O objetivo destes perfis foi avaliar se haveria deficiência de nutrientes na água residuária usada como substrato. 


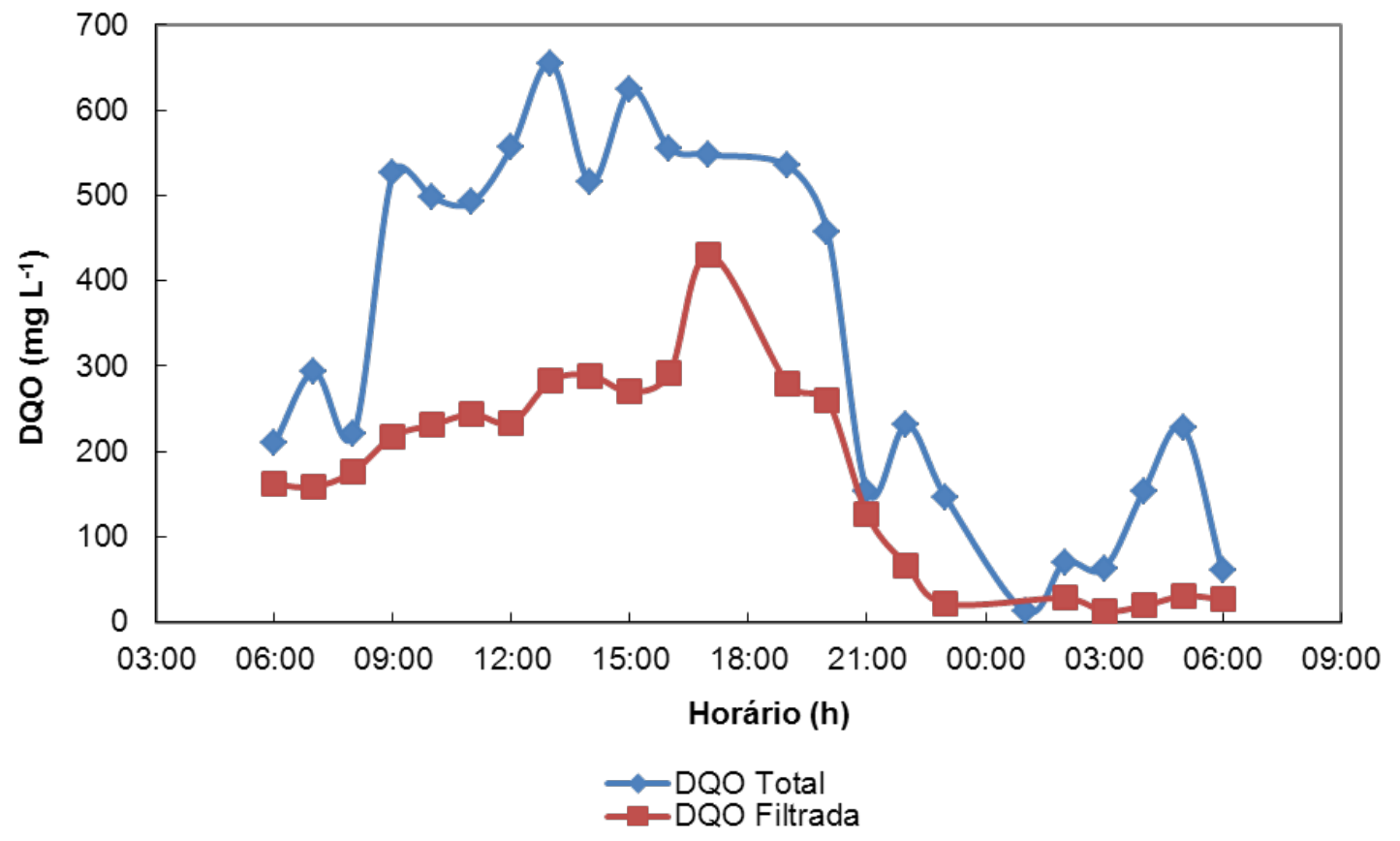

Figura 5.1 - Perfil temporal da DQO do esgoto afluente.

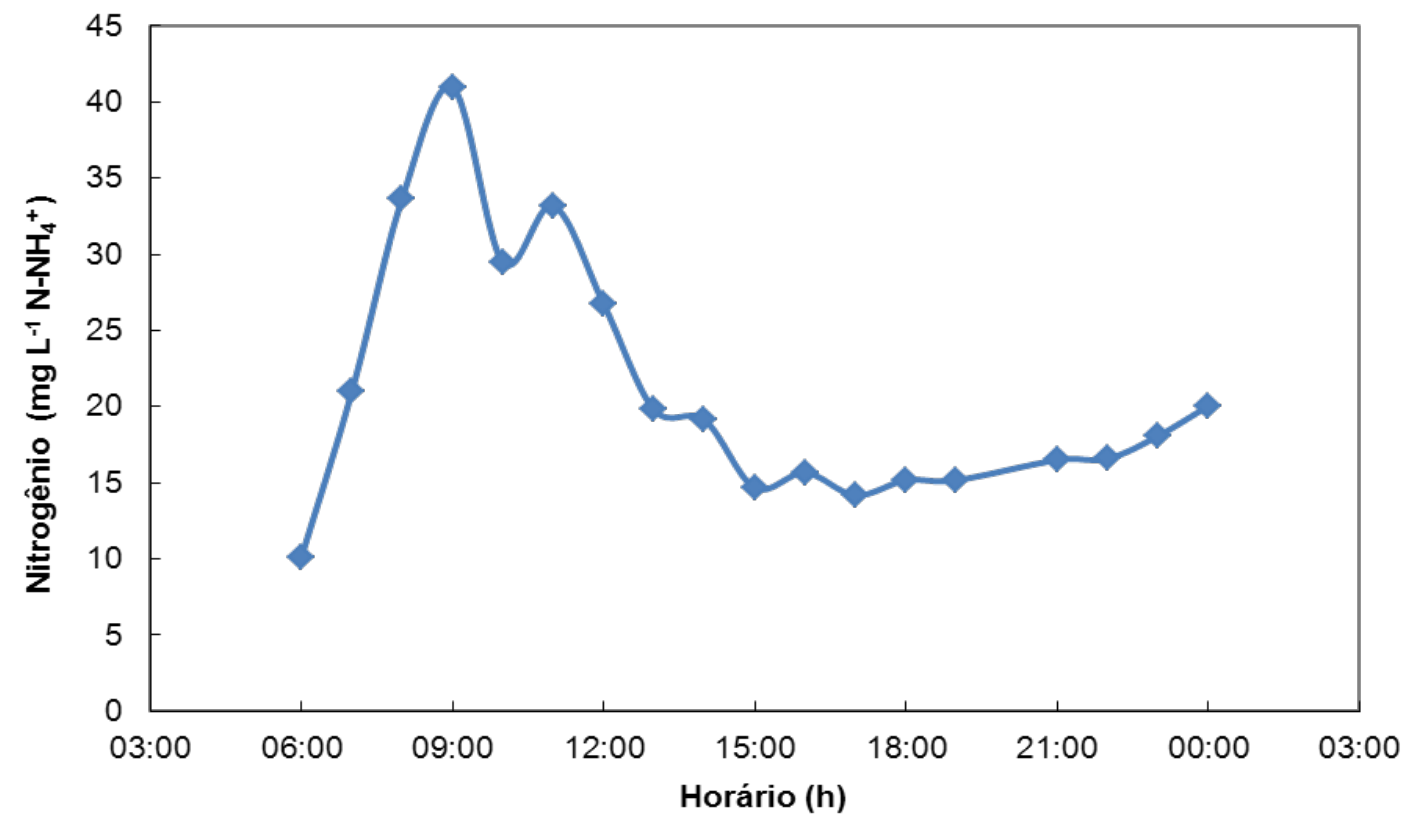

Figura 5.2 - Perfil temporal de nitrogênio amoniacal do esgoto afluente. 


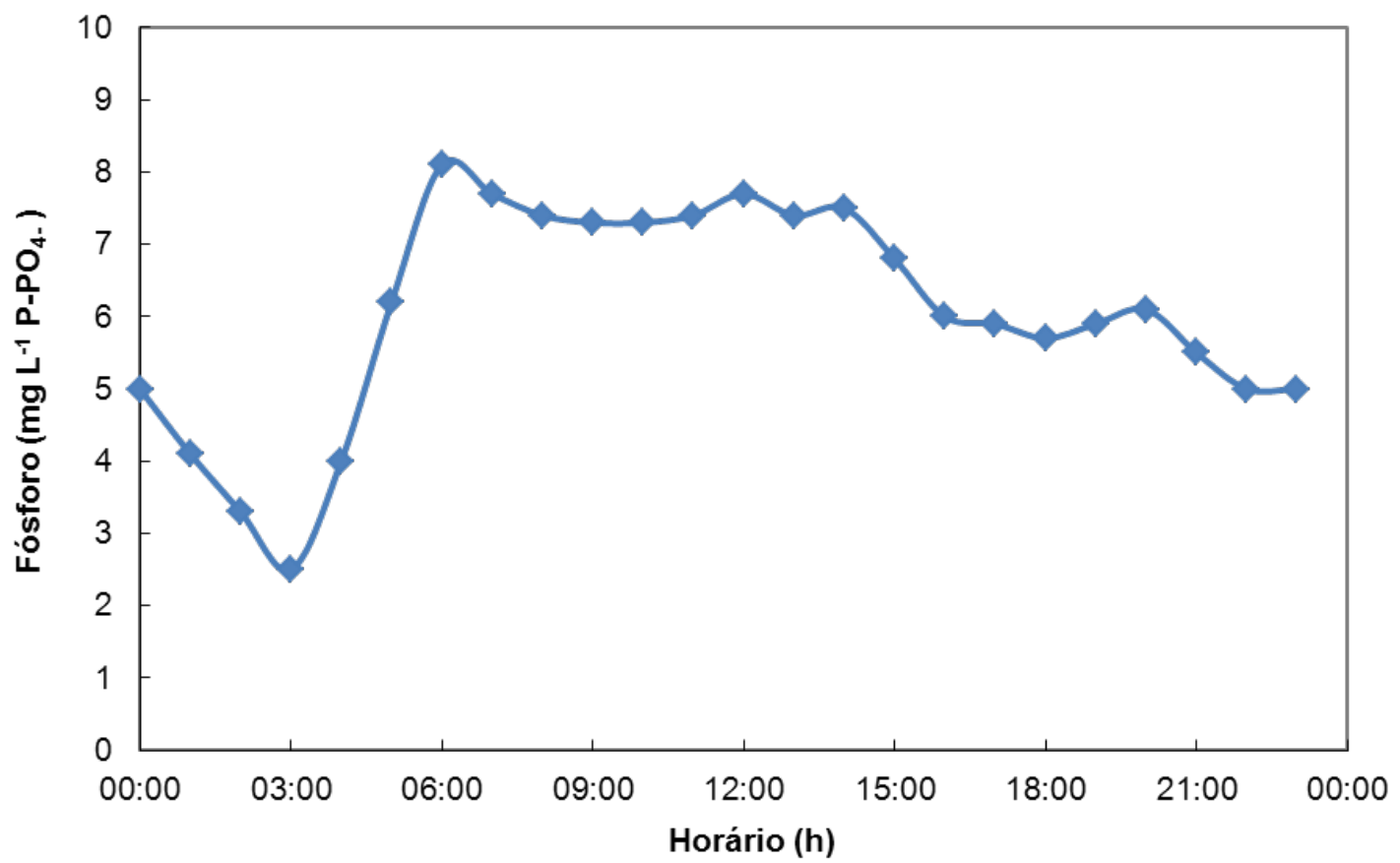

Figura 5.3 - Perfil temporal de fosfato do esgoto afluente.

Com base nestes perfis temporais, constatou-se que havia matéria orgânica disponível para o processo, bem como nitrogênio e o fósforo, em concentrações comumente encontradas em reatores anaeróbios tratando esgoto sanitário (Oliveira Netto, 2011).

A Figura 5.4 mostra os resultados das medidas de $\mathrm{pH}$ efetuadas durante a operação do reator. 


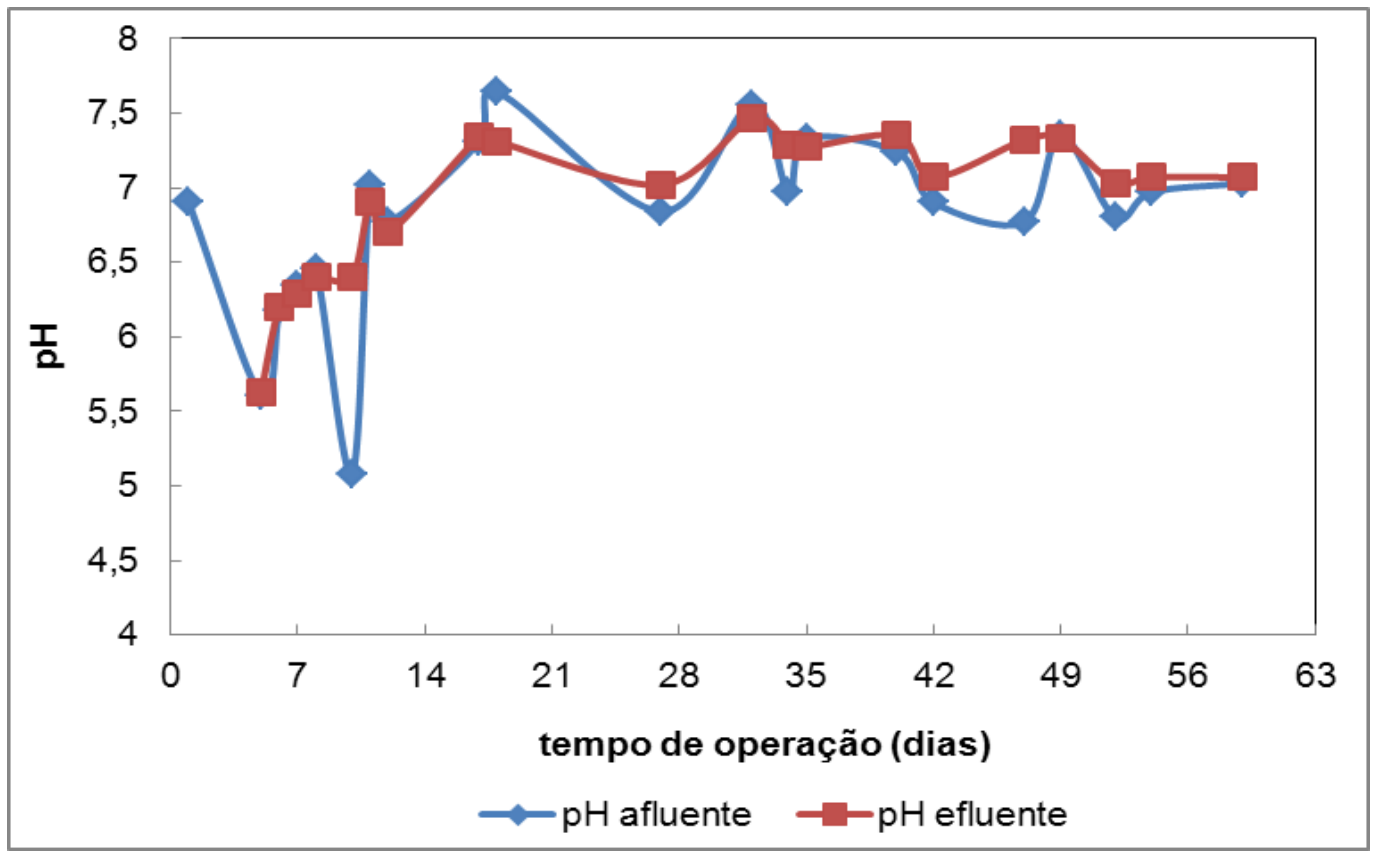

Figura 5.4 - Medidas de pH realizadas no afluente e efluente do reator na Etapa 1.

Pode-se observar que inicialmente, até o $12^{\circ}$ dia de operação, o pH efluente manteve-se abaixo do pH afluente indicando que poderia estar ocorrendo geração de ácidos orgânicos e, consequentemente hidrogênio, mesmo que em pequena concentração. Porém, após o $12^{\circ}$ dia de operação, o pH do efluente se elevou e convergiu para o mesmo valor do $\mathrm{pH}$ afluente, o que poderia ser o indicativo de baixa atividade acidogênica.

No $31^{\circ}$ dia de operação com a alteração do TDH (de 4 h para 2 h) visou-se promover o arraste do sistema dos possíveis microrganismos consumidores de hidrogênio, que apresentam velocidade específica máxima de crescimento $\left(\mu_{\text {máx }}\right)$ da ordem de $0,0167 h^{-1}$, enquanto as bactérias acidogênicas apresentam velocidades em torno de $0,083 \mathrm{~h}^{-1}$. Dessa forma, sob a influência de um tempo de detenção hidráulica mais baixo os microrganismos metanogênicos seriam incapazes de manter uma população estável e acabariam sendo eliminados do reator (Chen et al., 2001). 
Entretanto, mesmo com essa estratégia de redução do TDH após o $31^{\circ}$ dia de operação, o perfil observado continuou mostrando-se mais semelhante a de um sistema metanogênico, pois houve até mesmo geração de alcalinidade, conforme pode ser observado na Figura 5.5.

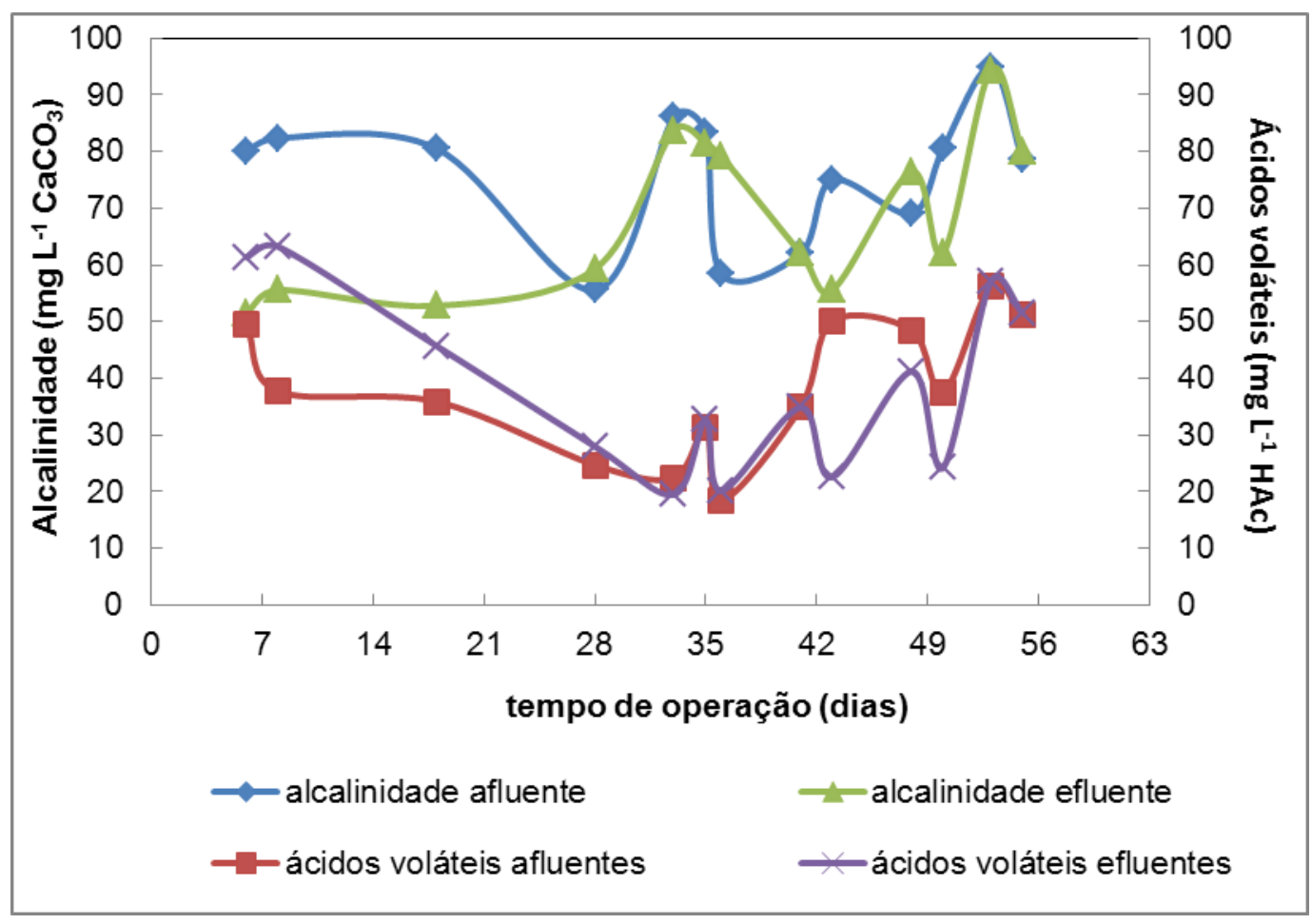

Figura 5.5 - Perfil temporal de alcalinidade $\left(\mathrm{mg} \mathrm{L}^{-1} \mathrm{CaCO}_{3}\right)$ e ácidos voláteis (mg $\left.\mathrm{L}^{-1} \mathrm{HAc}\right)$ do reator na Etapa 1.

Por meio da Figura 5.5, pôde-se notar ligeiras mudanças no perfil da alcalinidade e concentração de ácidos voláteis no reator. Essas mudanças mostraramse relacionadas à troca do TDH, pois logo após o $31^{\circ}$ dia de operação a alcalinidade total do reator (afluente e efluente) mostrou uma pequena queda, mas voltou a se estabilizar no decorrer da operação. O mesmo comportamento ocorreu com a concentração dos ácidos voláteis, que no primeiro momento da troca do TDH de 4 h 
para 2 h aumentaram ligeiramente ( $33^{\circ}$ dia de operação) e depois seguiram uma tendência de estabilização.

Mesmo nessa fase de transição, com a provável produção de ácidos, não houve produção volumétrica de hidrogênio mensurável.

Conforme observado na Figura 5.5, a produção de ácidos voláteis foi baixa ao longo da operação, indicando dificuldade na etapa de acidogênese do esgoto sanitário.

Na acidogênese compostos orgânicos são fermentados gerando ácidos, álcoois, dióxido de carbono e liberando o $\mathrm{H}_{2}$. A Reação 5.1 mostra, como exemplo, a produção de hidrogênio a partir de sacarose tendo ácido acético como produto final.

$\mathrm{C}_{12} \mathrm{H}_{22} \mathrm{O}_{11}+5 \mathrm{H}_{2} \mathrm{O} \rightarrow 4 \mathrm{CH}_{3} \mathrm{COOH}+4 \mathrm{CO}_{2}+8 \mathrm{H}_{2} \uparrow$ Reação 5.1

Considerando a reação 5.1 dentro do contexto das fontes de matéria orgânica disponíveis para a produção de hidrogênio a partir de esgoto sanitário, o aspecto limitante deste efluente provavelmente foi a falta de carboidratos na sua composição, conforme mostra a Figura 5.6.

A baixa geração de ácidos evidenciada pelos perfis de ácidos voláteis pode estar relacionada à ausência de fontes prontamente disponíveis para a produção de hidrogênio, como os carboidratos, que são os compostos preferenciais para a geração desse gás via fermentação (Hawkes et al., 2002).

Conforme pode ser visto na Figura 5.6, as concentrações de carboidratos no esgoto sanitário que alimentava o reator eram muito baixas, o que pode explicar a baixa produção de ácidos voláteis observada na operação do reator. 


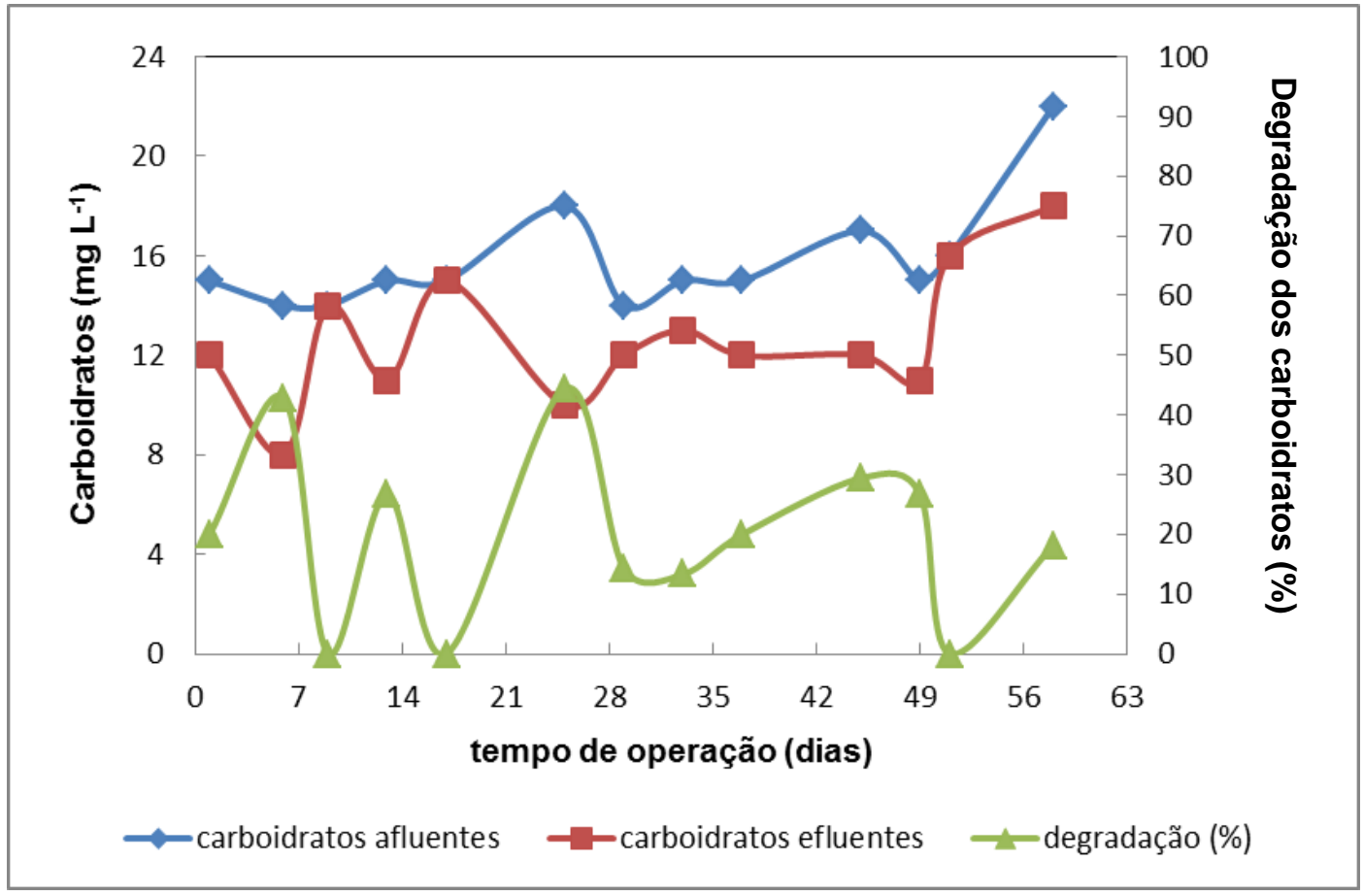

Figura 5.6 - Concentração e porcentagem de degradação de carboidratos do reator na Etapa 1.

É possível também que a inoculação não tenha contribuído muito para a operação do reator com esgoto sanitário, pois os microrganismos foram alimentados primeiramente com sacarose, tendo que se adaptar posteriormente ao esgoto.

Considerando a reação 5.1 e observando que tanto a geração de ácidos estava baixa quanto a produção de biogás, supõe-se que os carboidratos poderiam ser o maior fator limitante para a produção de hidrogênio a partir de esgoto sanitário, pois o mesmo apresentou concentrações mínimas destes compostos (Figura 5.6).

Na literatura, praticamente todos os trabalhos em que há a produção de hidrogênio, esta é realizada via fermentação de carboidratos, conforme pode ser visto no levantamento feito por Peixoto et al. (2011), em reatores de leito fixo. 
Uma vez que estes compostos não estejam presentes em concentrações suficientes, eles podem inviabilizar o processo.

Outro aspecto importante que evidenciou a instabilidade do reator enquanto sistema acidogênico ou metanogênico foi o fato de que a incipiente acidogênese não contribuiu para a produção de hidrogênio e o reator tampouco gerou metano ou apresentou remoções de matéria orgânica com eficiência de 50\% ou maiores, que é uma das características de processos metanogênicos.

A Figura 5.7 mostra a dinâmica de remoção de matéria orgânica deste reator.

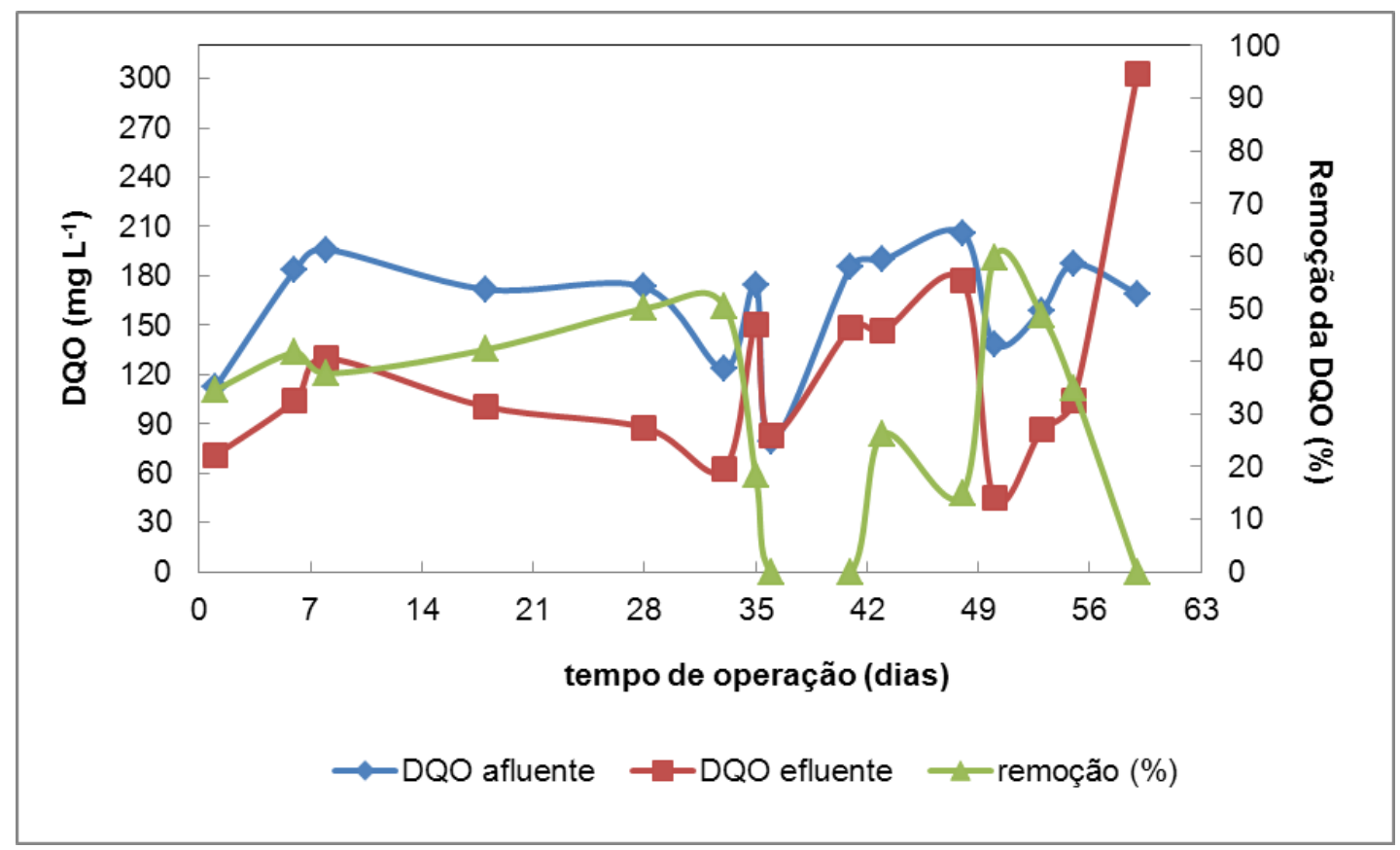

Figura 5.7 - Concentração e porcentagem de remoção de matéria orgânica medida como DQO no reator da Etapa 1.

Os resultados das análises de ácidos voláteis, alcalinidade e DQO, por si não foram capazes de caracterizar o reator como um sistema acidogênico ou metanogênico. 
A fermentação para a produção de hidrogênio, provavelmente não ficou definida devido a baixa concentração de compostos que pudessem gerar $\mathrm{H}_{2}$.

Por outro lado, pontualmente, a geração de alcalinidade bem como a ocorrência de baixa concentração de metano no biogás (Figura 5.8), mostram que de alguma forma, microrganismos metanogênicos estariam se desenvolvendo no reator a despeito de seu TDH de $2 \mathrm{~h}$.

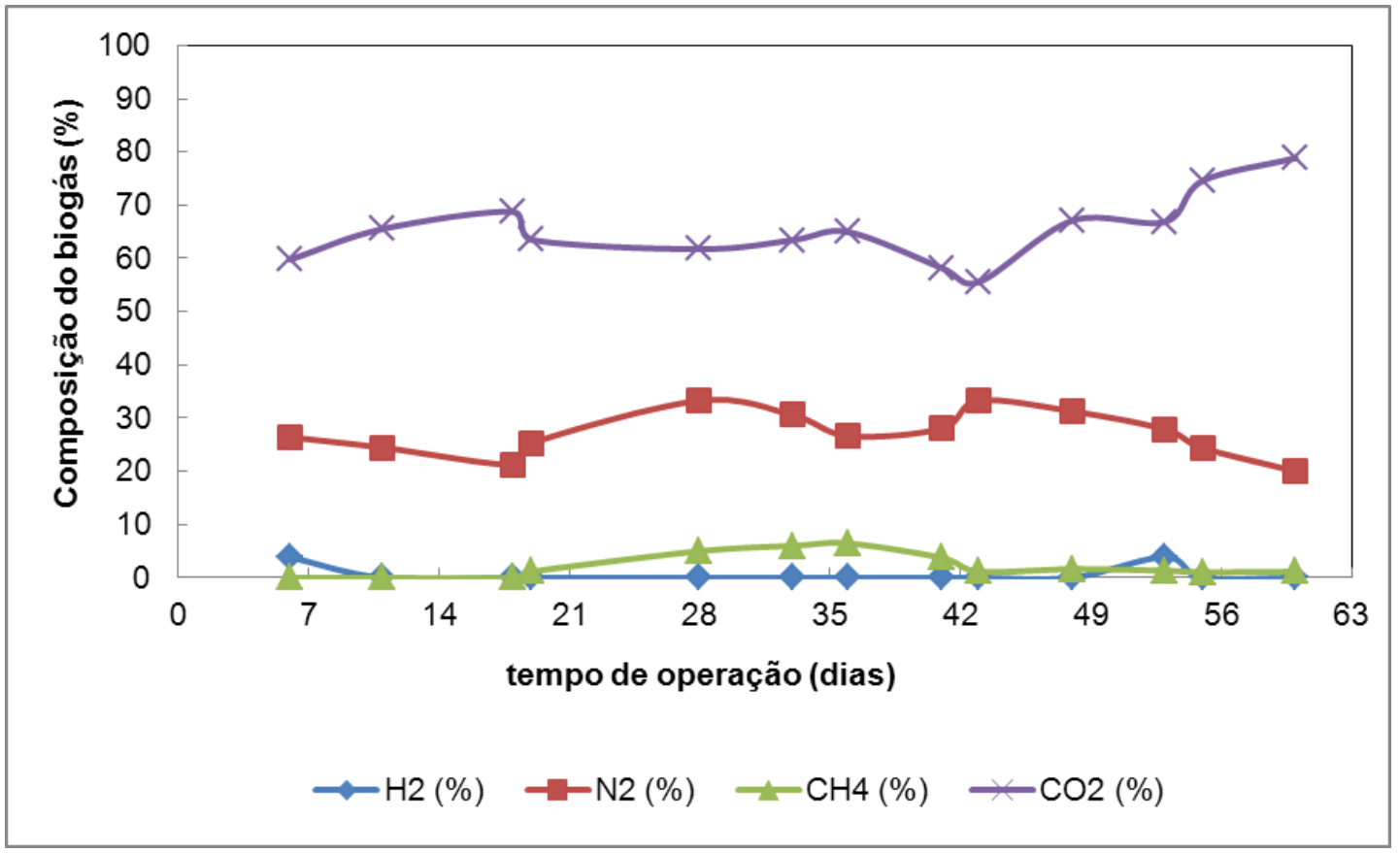

Figura 5.8 - Composição do biogás do reator na Etapa 1.

A um TDH baixo, somente a colmatação do leito poderia gerar zonas de estagnação onde os microrganismos metanogênicos pudessem se aderir, e suspeita-se que isso tenha ocorrido devido ao visível depósito de material nos interstícios dos suportes de polietileno empacotado, conforme se observa na Figura 5.9. 


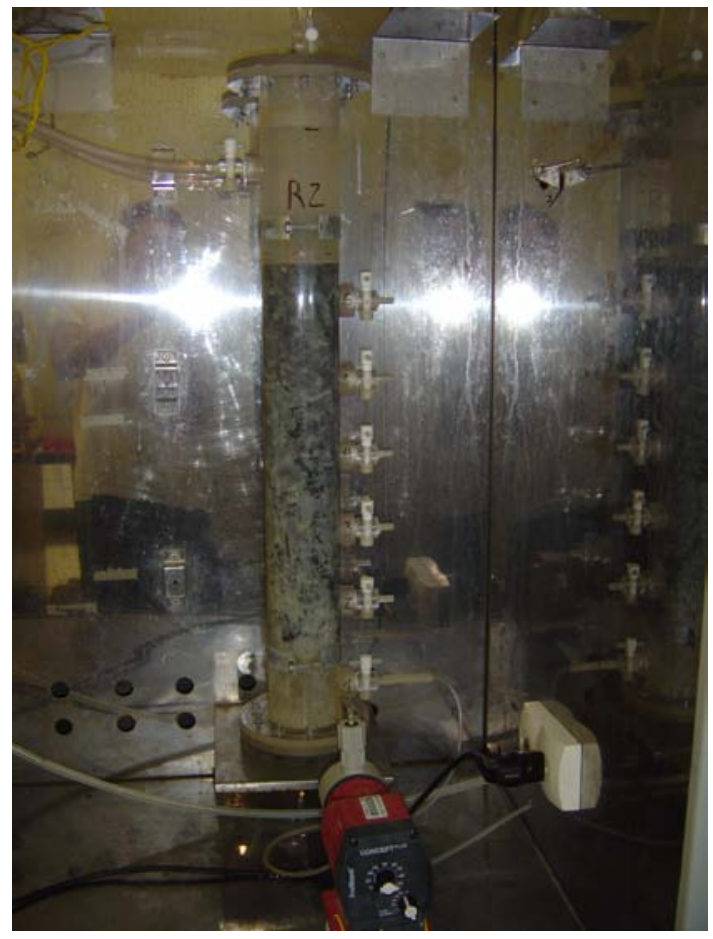

Figura 5.9 - Leito empacotado com acúmulo de material intersticial na Etapa 1.

Nesta etapa não foram mostrados resultados de vazão de biogás, pois o volume de gás produzido foi muito pequeno, não atingindo a pressão mínima de 8 mbar para o início do funcionamento do medidor de gás Milligas counter (Ritter®).

5.2 - Etapa 2 - Avaliação do efeito da suplementação com carboidratos sobre a produção de hidrogênio a partir de esgoto sanitário por reatores anaeróbios de fluxo ascendente com leito empacotado constituído por aparas de polietileno

Nesta etapa as hipóteses testadas foram a de que uma redução mais drástica do TDH poderia impedir o acúmulo de microrganismos indesejáveis nos interstícios do leito fixo e que a concentração de carboidratos no esgoto sanitário seria fator 
determinante para a produção de hidrogênio. É importante reforçar que essas duas hipóteses foram elaboradas com base nas observações realizadas na etapa anterior (Etapa 1).

Os tempos de detenção hidráulica empregados foram de 1 h para o reator R1 e $2 \mathrm{~h}$ para o reator R2. As vazões empregadas foram de $40 \mathrm{~mL} \mathrm{~min}{ }^{-1}$ e $20 \mathrm{~mL} \mathrm{~min}^{-1}$, resultando respectivamente nos TDH de 2 h e 1 h.

Apesar da variação nas correntes de alimentação dos reatores, as quais foram determinadas pela seqüência de alterações apresentadas no fluxograma da Figura 4.9 do Capítulo 4 (Material e Métodos), somente pequenas oscilações foram registradas, conforme pode ser visto na Figura 5.10.

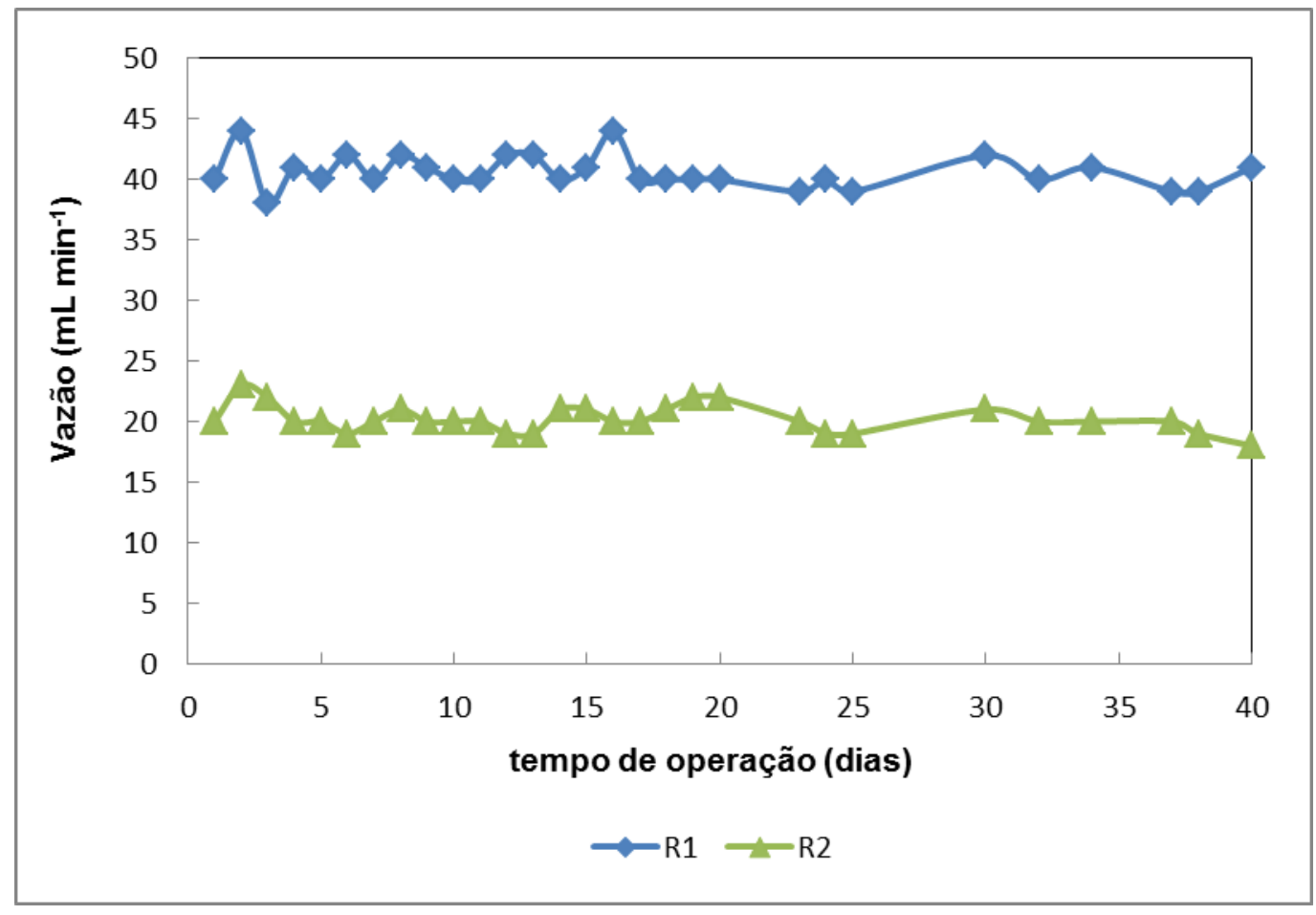

Figura 5.10 - Vazões de trabalho dos reatores R1 e R2 na Etapa 2.

A estratégia de variação da concentração de sacarose apresentada no fluxograma da Figura 4.9 do Capítulo 4, mostra que este procedimento foi delineado 
para que cada uma das fases não durasse mais que 5 dias, pois foi constatado por Rojas (2010) que reatores anaeróbios na mesma configuração que os usados neste estudo e operados com TDH de 2 h, tendo a alimentação com relação C/N baixa (40 ou menor), tendem a apresentar forte declínio na produção de hidrogênio após 27 dias de operação contínua. Dessa forma, conforme mostrado na Figura 4.9, cada fase de suplementação durou 5 dias, totalizando os 25 dias da estratégia e mais 15 dias de operação sem qualquer suplementação do esgoto sanitário.

Seguindo o protocolo experimental de Rojas (2010), o pH afluente não foi ajustado, pois no período inicial do monitoramento estava situado entre 6 e 7 , que foi a faixa de $\mathrm{pH}$ utilizada em seu estudo.

A Figura 5.11 mostra que nos primeiros 5 dias o pH afluente foi mais baixo em ambos os reatores. Provavelmente isso ocorreu porque nos 5 dias iniciais os reatores foram alimentados somente com meio de nutrientes e sacarose, o que favoreceu uma rápida acidificação na zona de entrada e mistura dos reatores, onde as amostras do afluente eram coletadas. Do $5^{\circ}$ ao $10^{\circ}$ dia de operação, quando se operava com $75 \%$ da vazão em solução de sacarose e $25 \%$ de esgoto sanitário, o pH afluente dos reatores apresentou um ligeiro aumento, pois o $\mathrm{pH}$ do esgoto sanitário oscilava entre 6,8 e 7. 


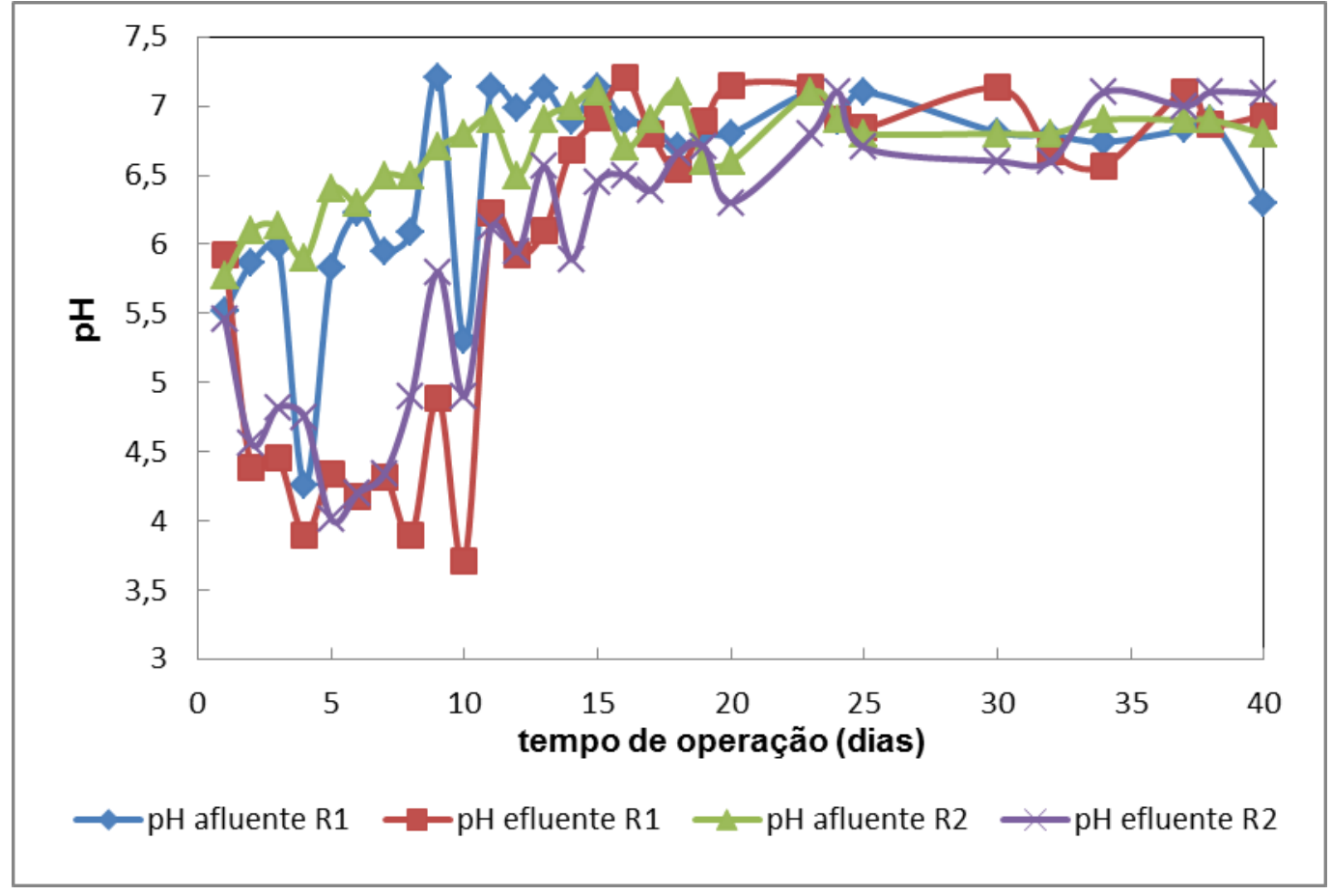

Figura 5.11 - Variação do pH afluente e efluente dos reatores R1 e R2 na Etapa 2.

É possível que a alcalinidade do esgoto sanitário tenha influenciado no $\mathrm{pH}$, pois após os 10 dias de operação, quando o reator passou a ser alimentado com $50 \%$ de solução de sacarose e $50 \%$ de esgoto sanitário, tanto o pH afluente como o efluente dos reatores sofreram uma abrupta mudança. Esse comportamento a partir do $10^{\circ}$ dia de operação também foi apresentado pelos perfis de geração de biogás e de ácidos, conforme se observa nas Figuras 5.14, 5.15, 5.17 e 5.19, respectivamente

Outra possível causa do aumento do $\mathrm{pH}$ pode ter sido a diminuição da geração de ácidos, que foi observada nas Figuras 5.16 e 5.18 na zona de entrada dos reatores.

A Figura 5.12 ilustra a diminuição progressiva da concentração de matéria orgânica nos reatores, que esteve diretamente ligada ao decréscimo da concentração de sacarose, uma vez que o esgoto sanitário, apresentava como DQO solúvel apenas 
$175 \mathrm{mg} \mathrm{L}^{-1}$, em média.

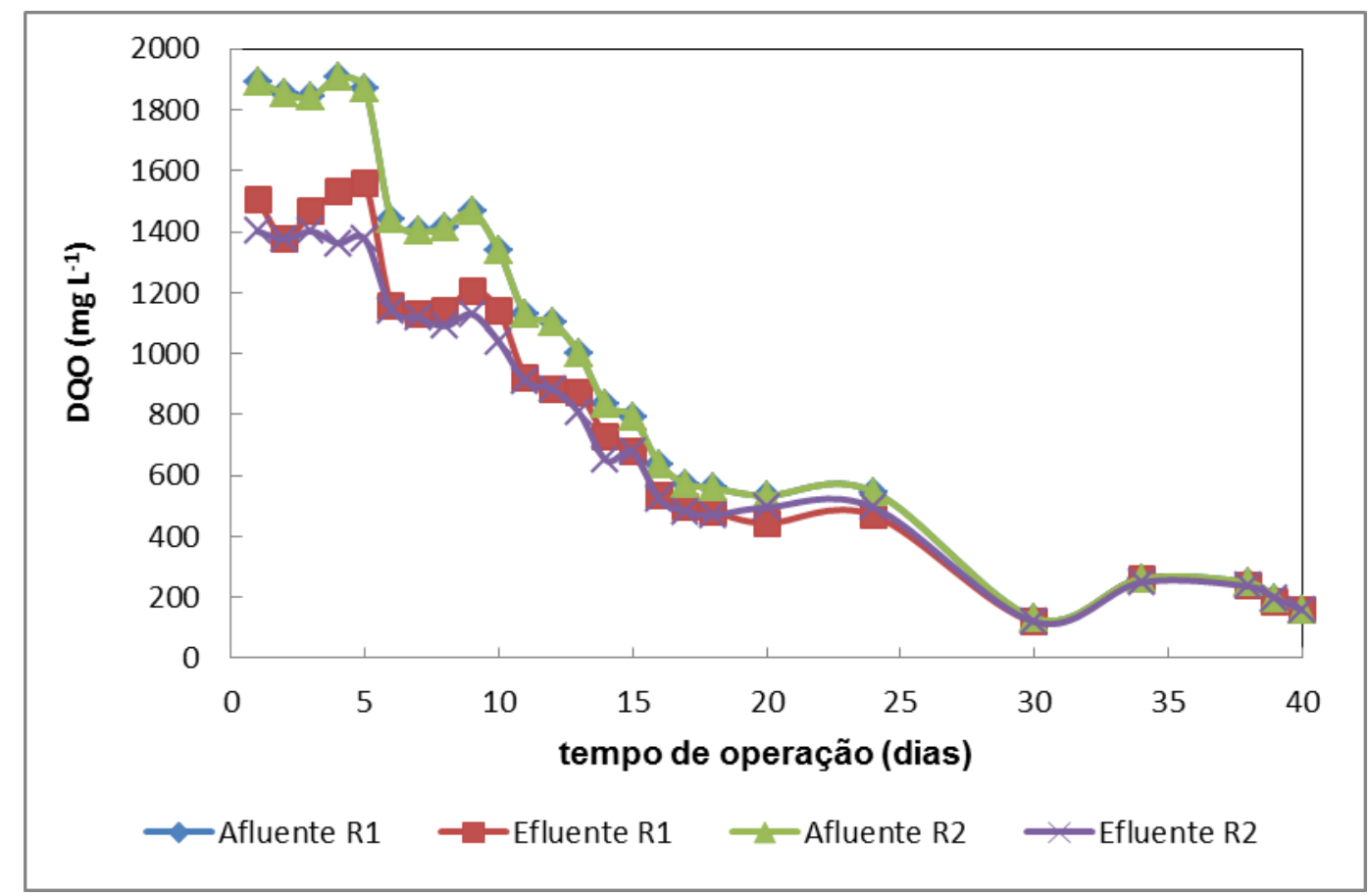

Figura 5.12 - Concentrações de matéria orgânica afluente e efluente medidas como mg L ${ }^{-1}$ de DQO nos reatores da Etapa 2.

Comparando-se os resultados de DQO afluente e efluente nos reatores R1 e R2, observa-se que houve uma baixa remoção de DQO, o que já era esperado para os sistemas acidogênicos, que se caracterizam pela formação e acumulação da maioria dos intermediários do processo de digestão anaeróbia. A média de remoção de DQO no reator (R1) foi de 14,7\% e no reator R2 foi de 16,8\%. Já a degradação de carboidratos foi de 80,2\% para o reator R1 e 89,9\% para o reator R2, conforme se observa na Figura 5.13.

O reator R2 (TDH 2 h) apresentou degradação dos carboidratos ligeiramente superior a do reator R1, o que era esperado tendo em vista que o TDH de $2 \mathrm{~h}$ pode 
alcançar degradação de carboidratos acima de $90 \%$, de acordo com os resultados de Rojas (2010), operando a mesma configuração de reator e usando o mesmo substrato empregado nesta etapa.

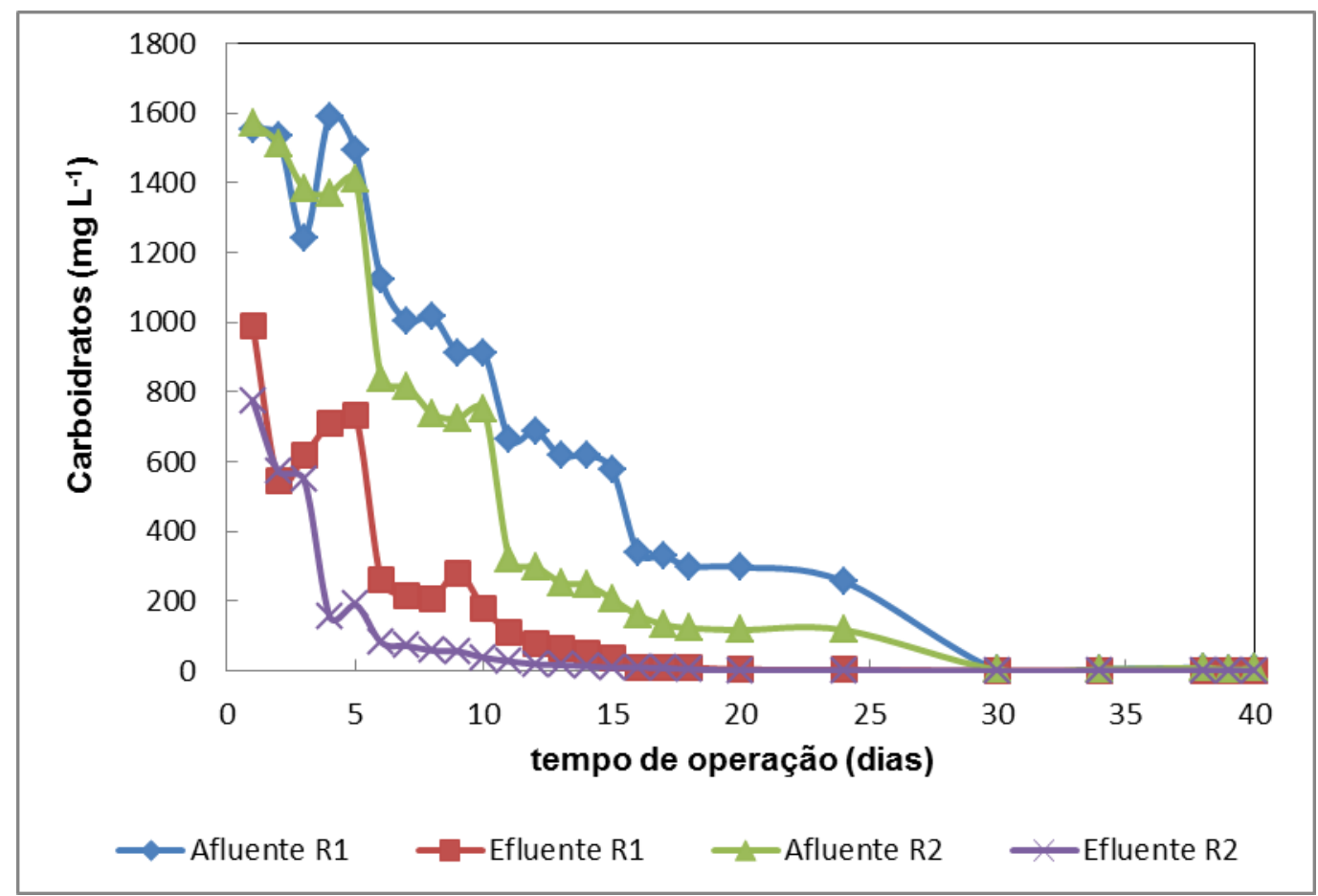

Figura 5.13 - Concentrações de carboidratos afluente e efluente dos reatores R1 e R2 na Etapa 2.

As Figuras 5.14 e 5.15 mostram que a partir do $10^{\circ}$ dia de operação não houve mais detecção de vazão volumétrica de biogás nos reatores R1 e R2, o que implicou na determinação de uma concentração crítica de sacarose no esgoto, que foi de aproximadamente $0,9 \mathrm{~g} \mathrm{~L}^{-1}$.

Este resultado colaborou para o entendimento do experimento da etapa anterior, uma vez que o reator operado na Etapa 1 continha menos de 0,010 $\mathrm{g} \mathrm{L}^{-1}$ de carboidratos, o que foi muito inferior a concentração crítica de $0,9 \mathrm{~g} \mathrm{~L}^{-1}$ determinada nesta etapa. 
Embora os reatores R1 e R2 tenham sido operados com TDHs diferentes, os resultados na produção volumétrica de hidrogênio foram muito semelhantes, o que pode estar relacionado ao fato dos reatores não terem sido operados numa condição permanente, ou seja, com uma concentração fixa de substrato que favorecesse o estabelecimento da biomassa produtora de hidrogênio.

O perfil de queda na produção de hidrogênio assemelha-se com o assumido pela diminuição da concentração de carboidratos afluentes aos sistemas, conforme mostrado na Figura 5.13. Esse fato indica que a concentração de matéria orgânica na forma de carboidratos mais simples como a sacarose mostrou-se essencial para a produção de hidrogênio, conforme relatam Hawkes et al. (2002).

Com base na observação das Figuras 5.14 e 5.15, não foi detectado metano nos reatores, fato que ocorreu ligeiramente na Etapa 1. É provável que o tempo de operação mais curto desta etapa e a predominância de acidogênese na maior parte do tempo de operação tenham inibido o desenvolvimento das arqueias metanogênicas.

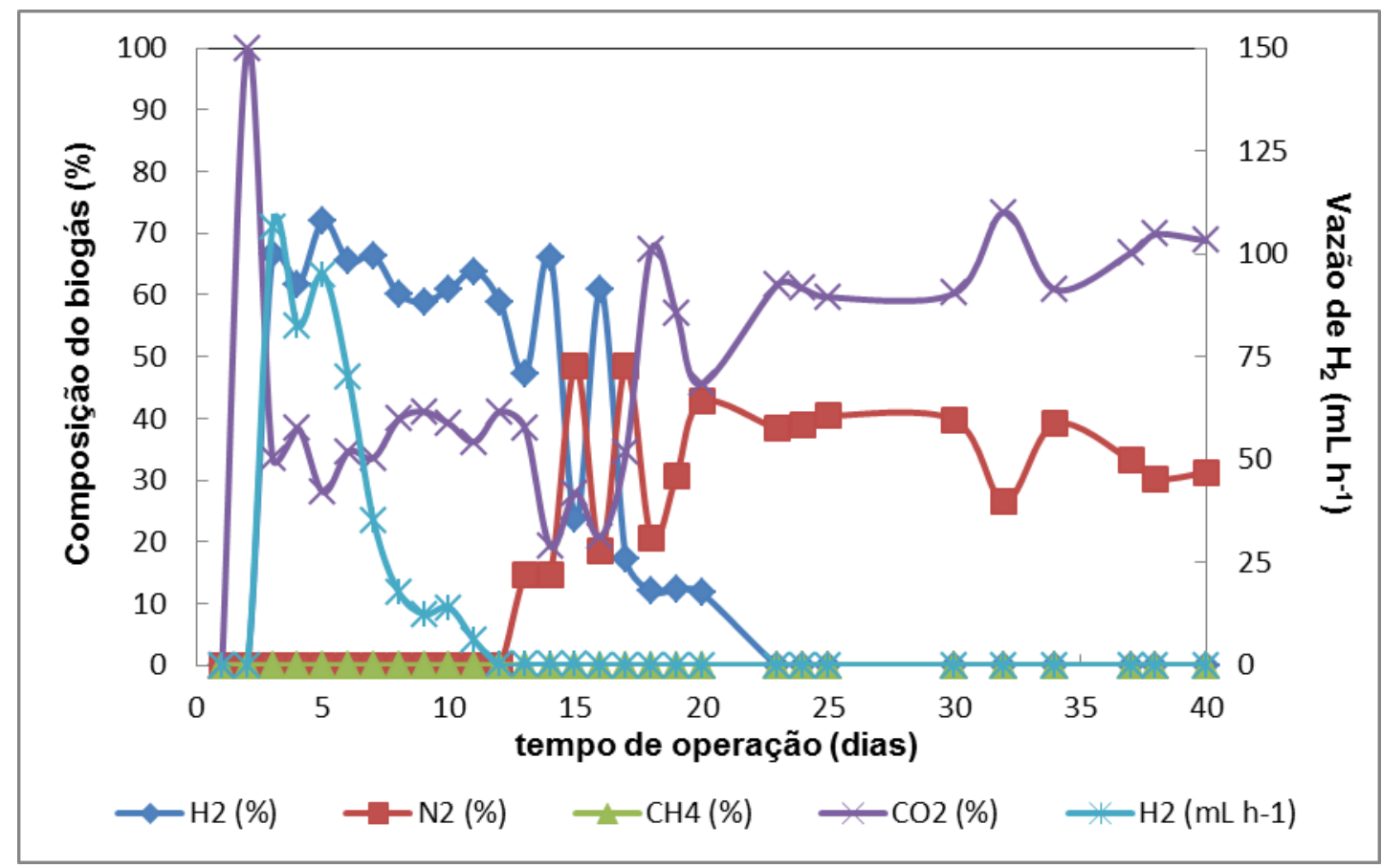

Figura 5.14 - Vazão volumétrica de hidrogênio e composição do biogás no reator R1 
(TDH 1h) na Etapa 2.

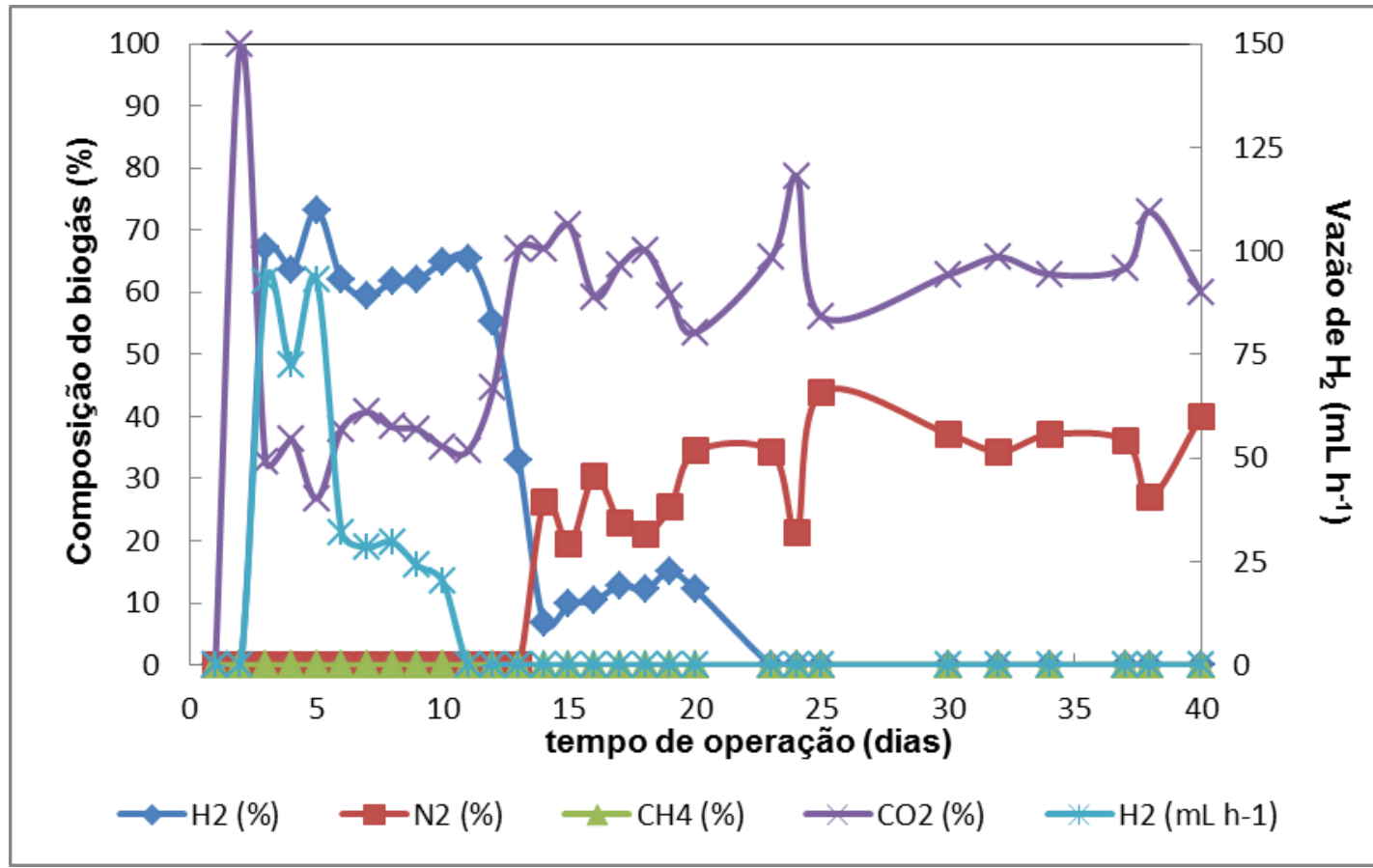

Figura 5.15 - Vazão volumétrica de hidrogênio e composição do biogás no reator R2 (TDH 2h) na Etapa 2.

As Figuras 5.16 e 5.18 indicam que pode ter havido uma rápida degradação de substrato na zona de entrada dos reatores até o $15^{\circ}$ dia de operação, período no qual ainda havia suplementação do esgoto sanitário com solução de sacarose e nutrientes.

A exemplo da tendência apresentada pelos reatores em relação a diminuição da vazão volumétrica de hidrogênio concomitantemente a diminuição de carboidratos na alimentação dos reatores, os ácidos orgânicos efluentes também mostraram o mesmo comportamento no tocante à concentração e distribuição dos mesmos, conforme pode ser visto nas Figuras 5.17 e 5.19.

Os perfis de ácidos apresentados nas Figuras 5.17 e 5.19 mostram que embora o hidrogênio não pudesse ser mais medido volumetricamente, a acidogênese 
permaneceu ativa até o $20^{\circ}$ dia de operação, período no qual ainda havia suplementação com solução de sacarose correspondente a 25\% da vazão de alimentação dos reatores.

Logo, a concentração crítica para ocorrência de acidogênese nos dois sistemas foi de aproximadamente $0,45 \mathrm{~g} \mathrm{~L}^{-1}$ de sacarose.

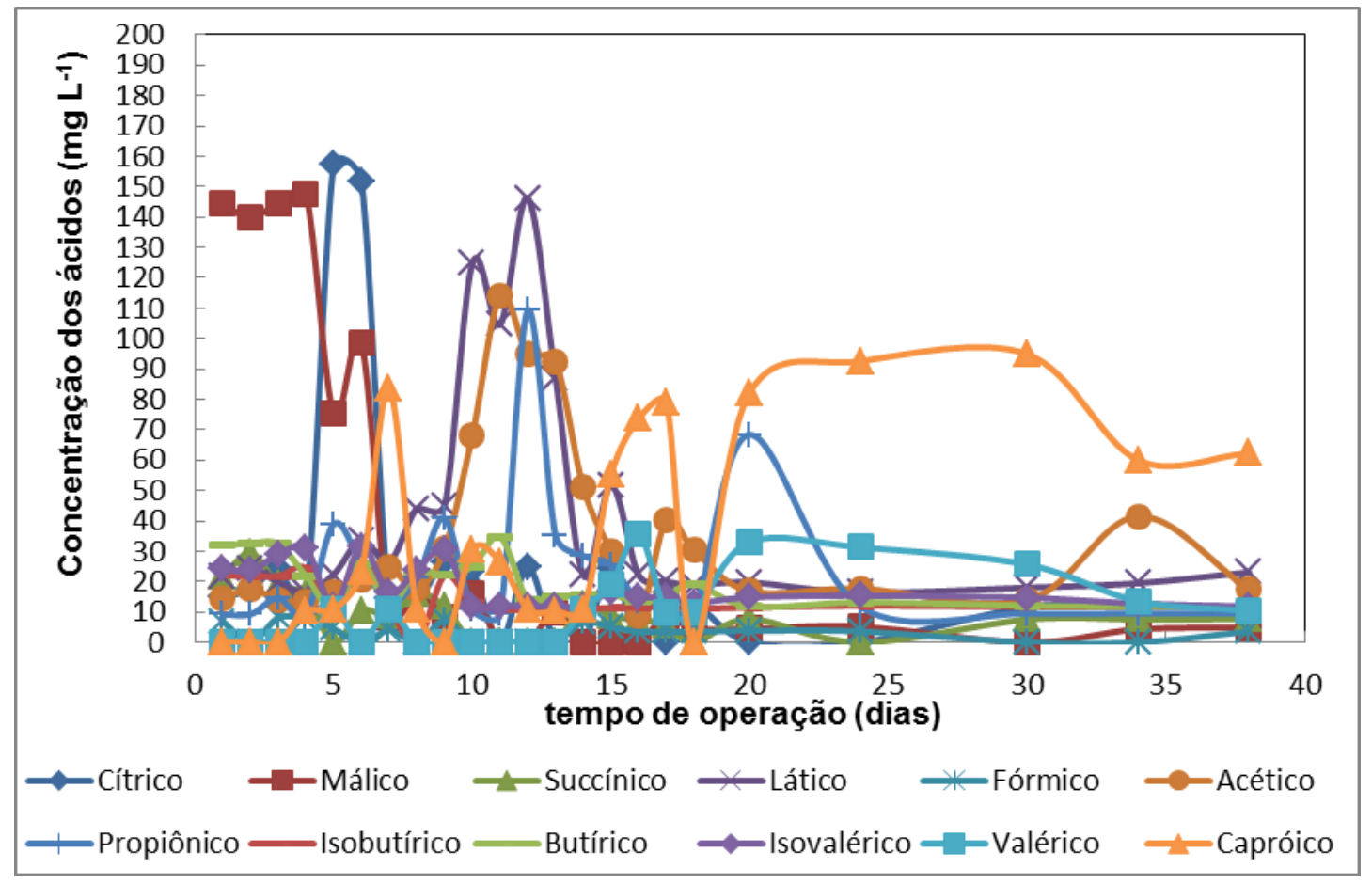

Figura 5.16 - Concentração de ácidos orgânicos afluentes ao reator R1 na Etapa 2.

A presença de ácidos orgânicos em alta concentração no afluente de ambos os reatores na primeira fase da estratégia de alimentação conforme mostram as Figuras 5.16 e 5.18 ( $\mathrm{t}=5$ dias de operação) provavelmente esteve associada ao desenvolvimento de biomassa acidogênica na zona de entrada dos reatores. As coletas de afluente podem ter sido prejudicadas por microrganismos consumidores de carboidratos que se fixaram nessa região de entrada dos reatores. 


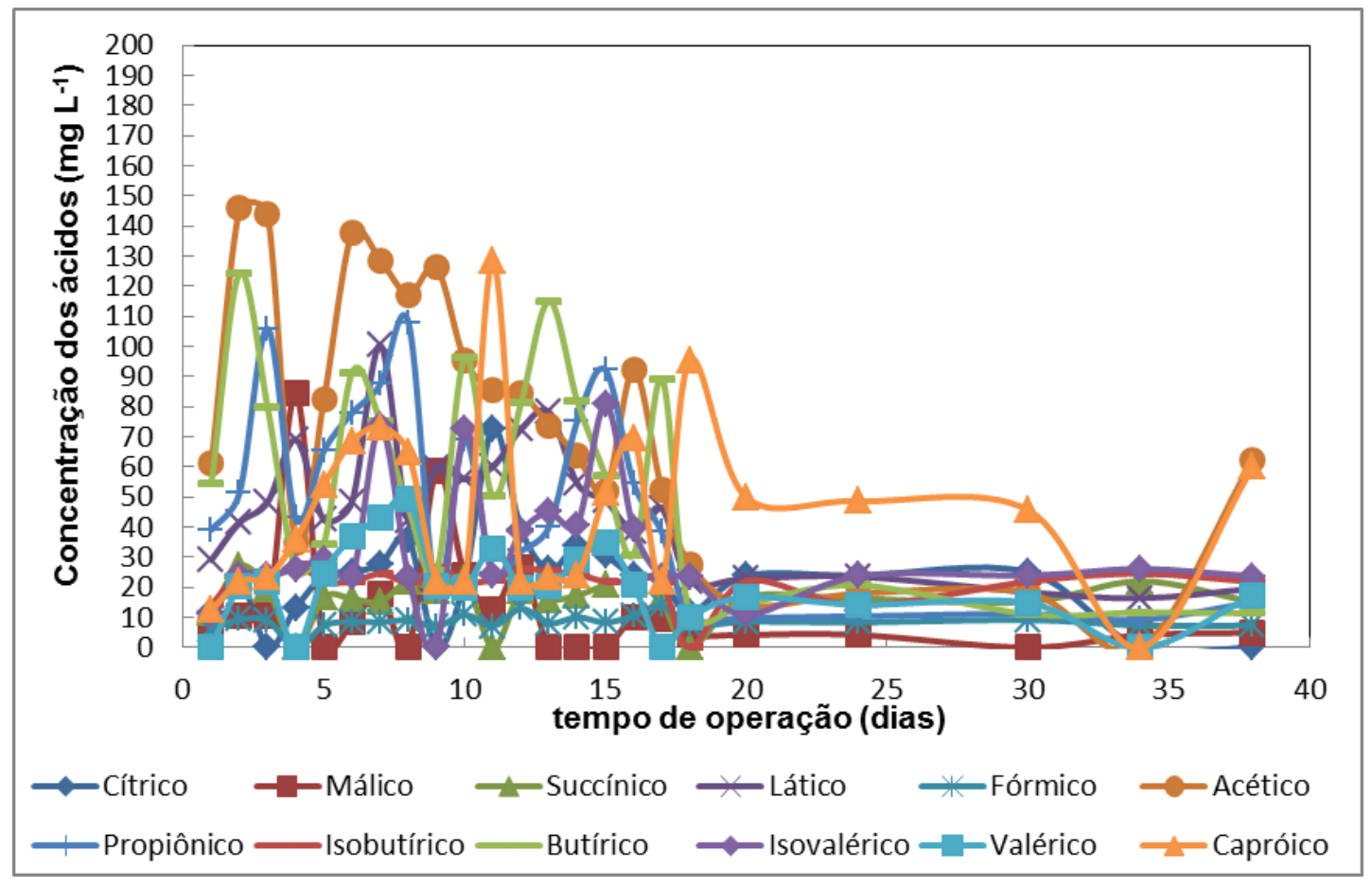

Figura 5.17 - Concentração de ácidos orgânicos efluentes ao reator R1 na Etapa 2.

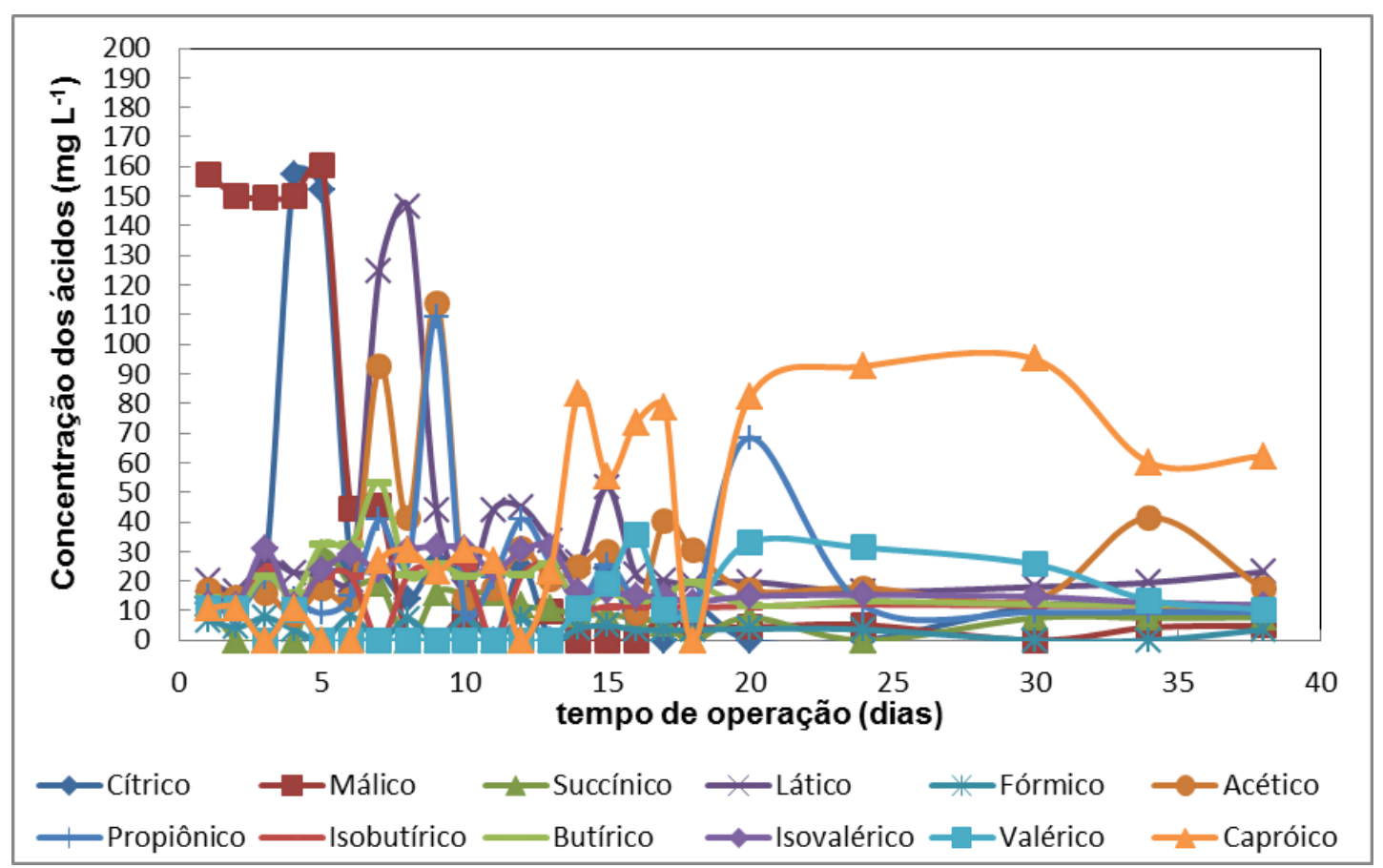

Figura 5.18 - Concentração de ácidos orgânicos afluentes ao reator R2 na Etapa 2. 
Mesmo com o declínio progressivo na geração de ácidos, não parece ter havido mudanças de rota metabólica pois os perfis observados nas Figuras 5.17 e 5.19 mostram uma fermentação direcionada principalmente para a formação de ácido acético e butírico, que segundo Khanal et al. (2004) constituem os produtos metabólicos mais comuns que são gerados na produção de hidrogênio.

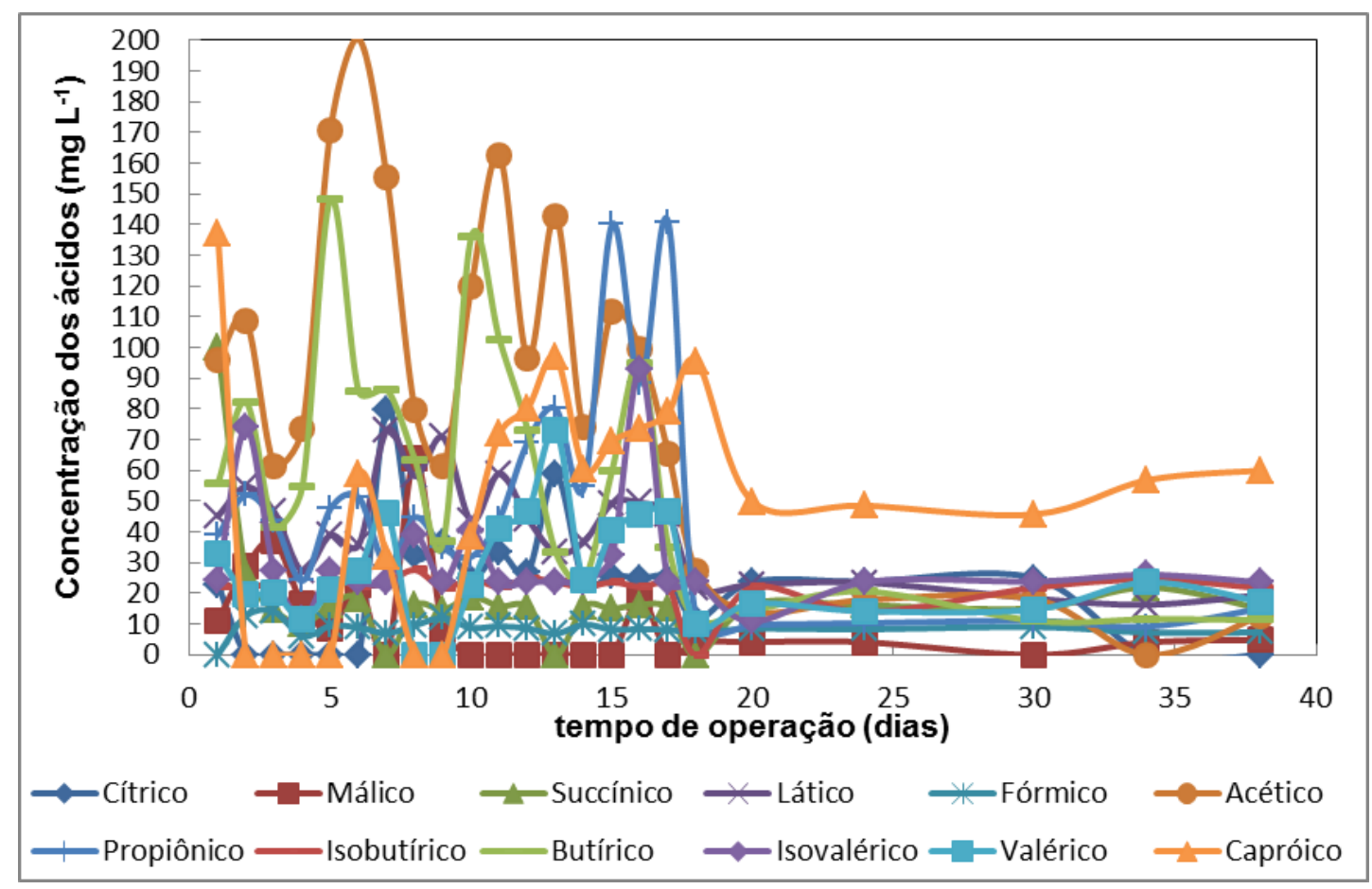

Figura 5.19 - Concentração de ácidos orgânicos efluentes ao reator R2 na Etapa 2.

É importante ressaltar que mesmo operando com TDH de $1 \mathrm{~h}$, ao final desta etapa houve grande acúmulo intersticial tanto no reator R2 quanto no reator R1, situados à esquerda e à direita na Figura 5.20, respectivamente. 


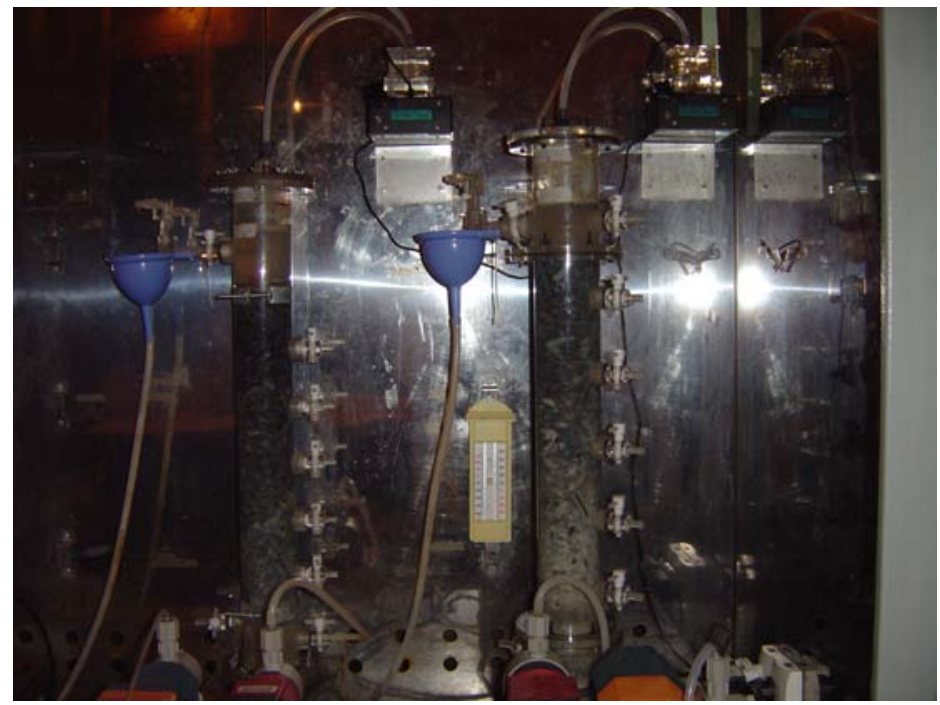

Figura 5.20 - Reatores anaeróbios de leito fixo constituído por empacotamento de aparas de polietileno utilizados na Etapa 2.

Esse acúmulo intersticial parece ter contribuído, na Etapa 1, para a fixação de microrganismos não relacionados à produção de hidrogênio a partir de esgoto sanitário. Já na Etapa 2, o reator operado com maior velocidade ascensional (R1 TDH 1 h) ficou visivelmente mais colmatado que o reator R2 (TDH - 2 h)

Provavelmente a velocidade ascensional mais alta no reator R1 não tenha contribuído para o arraste dos acúmulos entre os suportes, ao contrário, o aporte de sólidos nos interstícios deste reator acabou sendo maior.

Conforme relatado por Rojas (2010) e Peixoto et al. (2011), os reatores de leito empacotado com aparas de polietileno tendem a perder até 56\% do volume útil devido ao acúmulo intersticial e o TDH de operação passa a ser diferente do inicial, afetando as reações no sistema (Chang et al. 2002).

Outro fator que pode ter desfavorecido essa configuração de reator, levando a colmatação do leito, foi a operação com esgoto sanitário apresentando concentração média de $300 \mathrm{mg} \mathrm{L}^{-1}$ SST no afluente, já que não se dispunha de mecanismos de 
remoção de sólidos.

Contudo, mesmo com toda a problemática relacionada a configuração do reator, os resultados das Etapas 1 e 2 sugerem que a concentração de carboidratos no substrato foi o fator mais crítico para a produção de hidrogênio nas condições testadas.

\section{3 - Etapa 3 - Reatores em batelada para a produção de hidrogênio e metano a} partir de esgoto sanitário, glicerol, vinhaça, água residuária de parboilização de arroz e sacarose

Nesta etapa a hipótese testada foi a de que a suplementação do esgoto sanitário, verificada na Etapa 2, é necessária para a produção de hidrogênio, por isso outros resíduos foram testados em reatores em batelada a fim de determinar qual apresentaria maior potencial para essa aplicação, bem como o potencial de geração de metano a partir dos produtos gerados na fase acidogênica de cada substrato.

\subsection{1 - Potencial de produção de hidrogênio a partir de águas residuárias}

No decorrer da fase acidogênica, foi possível verificar o decréscimo de matéria orgânica em todos os substratos testados. Nos frascos contendo vinhaça, água residuária de parboilização de arroz e sacarose, as porcentagens de remoção foram de 42,7, 26,1 e 40,5\%, respectivamente. Seguindo essa tendência (Tabela 5.1), 
as constantes cinéticas aparentes de primeira ordem para remoção de DQO (k $\left.\mathrm{k}_{1}\right)$ foram mais altas para vinhaça, sacarose e água residuária de parboilização de arroz. Por outro lado, o esgoto sanitário e glicerol apresentaram 0,0043 e 0,0037 $\mathrm{h}^{-1}$, respectivamente, que foram valores muito baixos em relação aos obtidos com os outros substratos. Como consequência, o esgoto sanitário e o glicerol apresentaram uma pequena redução na DQO durante os experimentos, com porcentagens de remoção de 14,8 e 12,6\%, respectivamente (Figura 5.21).

Tabela 5.1 - Cinética de primeira ordem para remoção de DQO e carboidratos, e valores dos parâmetros da equação modificada de Gompertz para os substratos avaliados no estágio acidogênico.

\begin{tabular}{|c|c|c|c|c|c|c|c|c|c|c|c|}
\hline \multirow[b]{2}{*}{ Substrato } & \multicolumn{3}{|c|}{ DQO } & \multicolumn{3}{|c|}{ Carboidratos } & \multicolumn{5}{|c|}{ Hidrogênio } \\
\hline & $\begin{array}{l}\mathrm{C}_{\mathrm{DQO}} \\
\left(\mathrm{mg} \mathrm{L}^{-1}\right)\end{array}$ & $\begin{array}{l}\mathrm{k}_{1} \\
\left(\mathrm{~h}^{-1}\right)\end{array}$ & $\mathrm{R}^{2}$ & $\begin{array}{l}\mathrm{C}_{\mathrm{C}} \\
\left(\mathrm{mg} \mathrm{L}^{-1}\right)\end{array}$ & $\begin{array}{l}\mathrm{k}_{2} \\
\left(\mathrm{~h}^{-1}\right)\end{array}$ & $\mathrm{R}^{2}$ & $\begin{array}{c}\lambda \\
\text { (h) }\end{array}$ & $\begin{array}{c}\mathrm{R}_{\mathrm{m}} \\
(\mathrm{mL} / \mathrm{h})\end{array}$ & $\begin{array}{c}\mathrm{P} \\
(\mathrm{mL})\end{array}$ & $\begin{array}{l}\mathrm{R}_{\mathrm{S}} \\
\left(\mathrm{mL} \quad \mathrm{g}^{-1}\right. \\
\left.\mathrm{SSV} \mathrm{h}^{-1}\right)\end{array}$ & $\mathrm{R}^{2}$ \\
\hline Esgoto & 262 & 0,0043 & 0,97 & NS & NS & NS & - & - & - & - & - \\
\hline Glicerol & 368 & 0,0037 & 0,99 & NS & NS & NS & - & - & - & - & - \\
\hline Arroz & 285 & 0,0091 & 0,92 & 52 & 0,2192 & 0,96 & 8,2 & 0,13 & 6,82 & 0,28 & 0.93 \\
\hline Vinhaça & 375 & 0,0142 & 0,92 & 37 & 0,1036 & 0,99 & 10,7 & 0,84 & 6,25 & 2,95 & 0.99 \\
\hline Sacarose & 375 & 0,0123 & 0,92 & 327 & 0,1212 & 0,97 & 14,1 & 0,18 & 9,34 & 0,42 & 0.96 \\
\hline
\end{tabular}

NS - Não significativo.

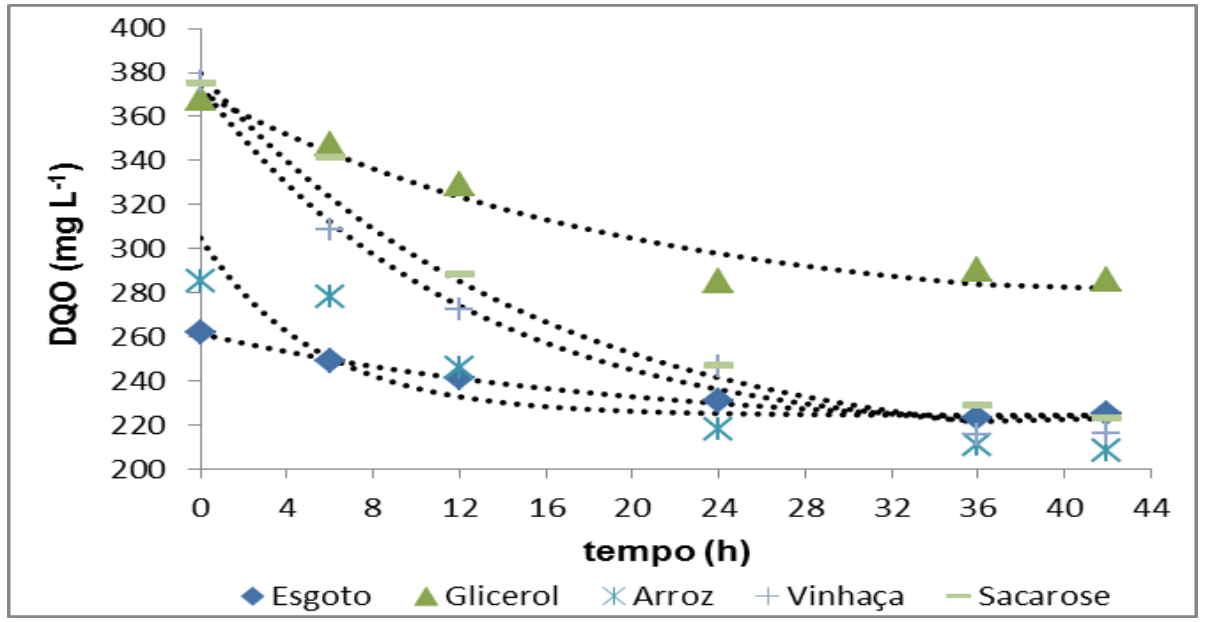

Figura 5.21 - Remoção da DQO dos reatores acidogênicos da Etapa 3; (...)

decaimento exponencial de primeira ordem. 
As diferenças na degradação da matéria orgânica ocorreram provavelmente devido a diferentes rotas metabólicas assumidas na conversão dos substratos em $\mathrm{CO}_{2}, \mathrm{H}_{2}$, ácidos e solventes.

De acordo com a Tabela 5.1, a água residuária de parboilização de arroz apresentou o maior valor para a constante cinética aparente de consumo de carboidratos, seguida pelas constantes calculadas para sacarose e vinhaça. Essas constantes não foram possíveis de ser estimadas para o esgoto sanitário devido a baixíssima concentração de carboidratos na sua composição (3 $\left.\mathrm{mg} \mathrm{L}^{-1}\right)$, e também para o glicerol, que apresentou concentração nula destes componentes (Figura 5.22). Isso certamente pode ter afetado a produção de hidrogênio para ambos os efluentes, pois os carboidratros são a fonte preferencial para a produção de hidrogênio.

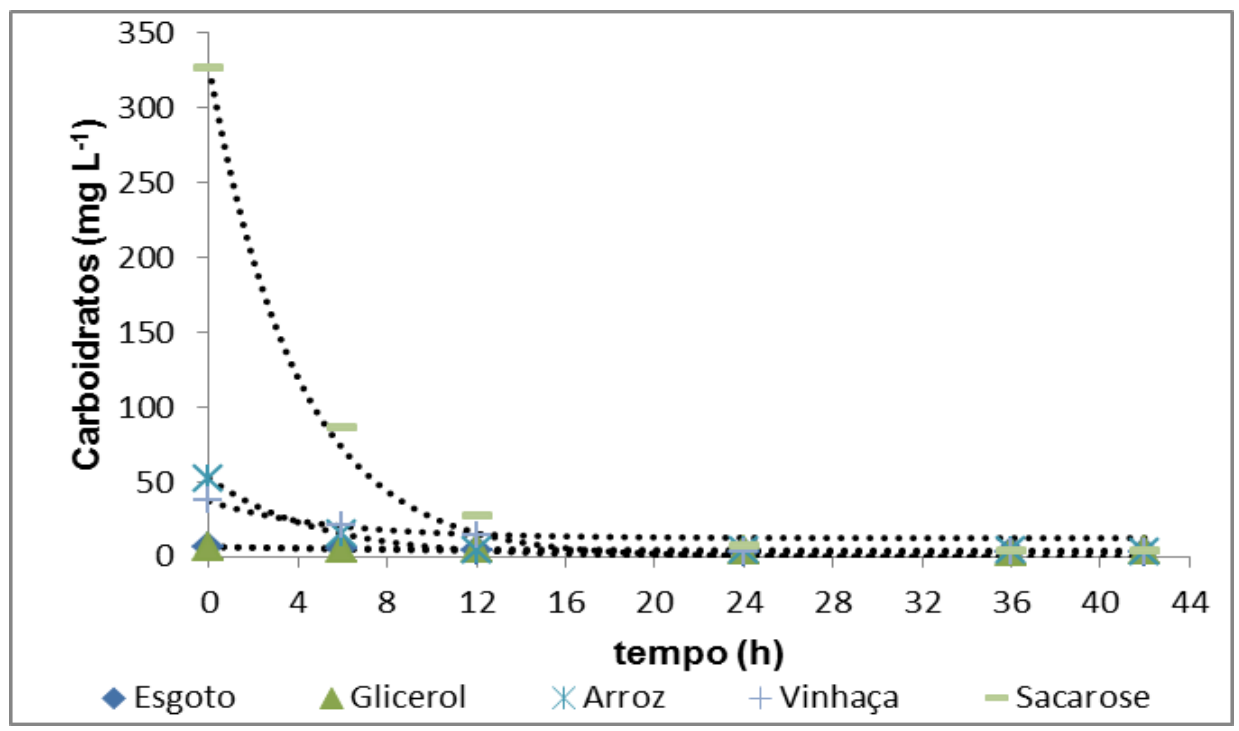

Figura 5.22 - Degradação de carboidratos nos reatores acidogênicos da Etapa 3;

(...) decaimento exponencial de primeira ordem.

Ao longo deste estágio, percebeu-se que a água residuária de parboilização de arroz, a vinhaça e a sacarose promoveram a produção de hidrogênio dentro das 
condições experimentais empregadas. De acordo com a Figura 5.23, esses sistemas apresentaram um tempo de adaptação que durou 8, 10 e 14 h para a água residuária de parboilização de arroz, vinhaça e sacarose, respectivamente. Logan et al. (2002) também observou diversos tempos de adaptação usando diferentes substratos em reatores em batelada. Em seu estudo, glicose, sacarose e melaço apresentaram tempos de aclimatação de 19 a 27 h, enquanto a água residuária de batatas necessitou de 40 h para que a produção de hidrogênio iniciasse.

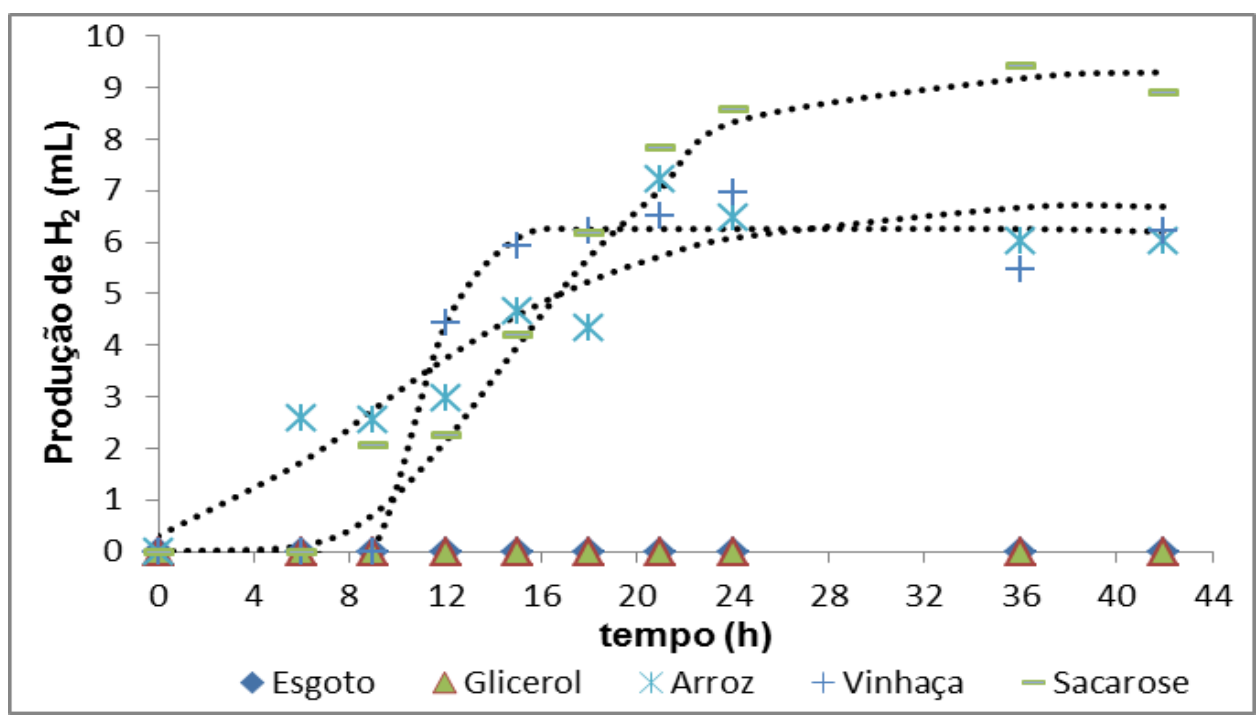

Figura 5.23 - Produção de hidrogênio pelos substratos avaliados na Etapa 3; (...) equação de Gompertz modificada.

De acordo com os resultados experimentais, nenhuma produção de hidrogênio foi detectada durante as 42 h de monitoramento do esgoto sanitário. De acordo com a Figura 5.24, no final do experimento, entre 24 e 36 h, uma pequena geração de ácido butírico foi detectada $\left(7.13 \mathrm{mg} \mathrm{L}^{-1}\right)$, enquanto as concentrações dos outros ácidos permaneceram constantes. Isso indicou que a matéria orgânica disponível não pôde ser convertida satisfatoriamente em metabólitos solúveis e biogás. Apesar disso, uma pequena quantidade de hidrogênio deve ter sido 
produzida, pois houve uma redução de $14,8 \%$ na concentração inicial de matéria orgânica.

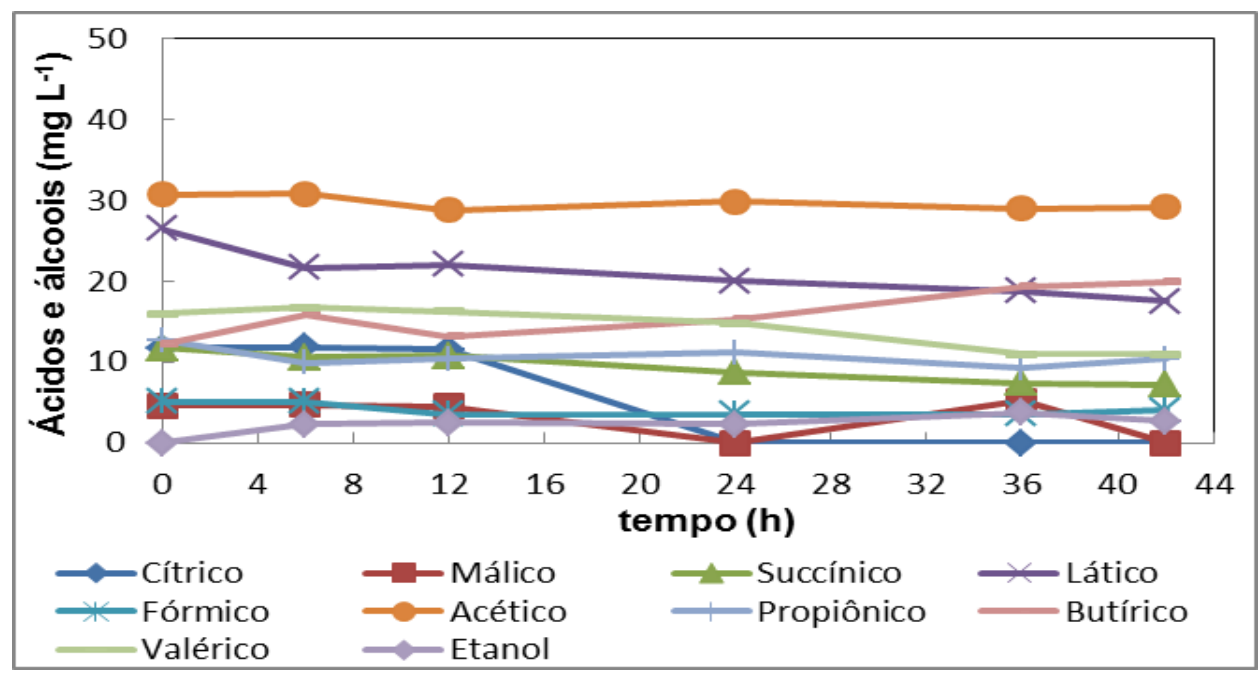

Figura 5.24 - Metabólitos solúveis produzidos pelo reator com esgoto sanitário na Etapa 3.

No estudo de Van Ginkel et al. (2005), no qual foram monitorados reatores em batelada a $23^{\circ} \mathrm{C}$ e pH 6,1, a água residuária de origem doméstica produziu $0.04 \mathrm{~L}$ $\mathrm{H}_{2}$ g DQO$^{-1}$. Essa produção de hidrogênio ocorreu porque essa água residuária doméstica foi concentrada 25 vezes, produzindo uma solução com DQO solúvel de 2,6 g L ${ }^{-1}$ e uma concentração de glicose de $294 \mathrm{mg} \mathrm{L}^{-1}$. Van Ginkel et al. (2005) argumentaram que a concentração de glicose na água residuária bruta (sem a aplicação da técnica de concentração) foi insuficiente para fazer crescer as bactérias produtoras de hidrogênio. O mesmo poderia ser argumentado neste estudo, pois uma concentração insignificante de carboidratos foi detectada no esgoto sanitário que foi utilizado com a finalidade de produzir hidrogênio. As fontes de carbono orgânico remanescentes para a produção de hidrogênio no esgoto foram provavelmente 
proteínas e lipídios, que são os compostos mais comumente encontrados nos esgotos sanitários.

Okamoto et al. (2000) avaliaram lipídeos (pele de frango e gordura), proteínas (ovos e carne magra) e carboidratos para a produção de hidrogênio e obtiveram 1,43 (pele de frango), 1,56 (gordura), 1,31 (ovo) e 1,75 (carne magra) mL $\mathrm{H}_{2} \quad \mathrm{~g}^{-1}$ DQO, que foram resultados muito baixos quando comparados à produção a partir de carboidratos, como por exemplo cenoura, que gerou 8,8 mL $\mathrm{H}_{2}$ $\mathrm{g}^{-1}$ DQO. Além disso, a produção de hidrogênio a partir de carboidratos (cenoura), proteínas (carne) e lipídios (gordura) apresentaram fases lag com duração de aproximadamente 12, 30 e $100 \mathrm{~h}$, respectivamente. As longas fases lag necessárias para a geração de hidrogênio a partir de proteínas e lipídios também podem explicar por que o hidrogênio não foi detectado no tempo de experimento de $42 \mathrm{~h}$.

É provável que, neste estudo, como no de Okamoto et al. (2000), a produção de hidrogênio obtida a partir de proteínas tenha sido extremamente baixa ou nula, porque a reação de Stickland pode ter ocorrido durante o processo de geração do gás. A degradação de aminoácidos, em si, é capaz de produzir hidrogênio a partir de proteínas, mas a reação de Stickland dos clostridiums utiliza o hidrogênio molecular como um doador de elétrons para a desaminação redutiva quando aminoácidos como a glicina são degradados (Nagase, 1982). Portanto, mesmo se o hidrogênio fosse produzido a partir da degradação de aminoácidos, ele seria rapidamente consumido na reação de Stickland. Além disso a degradação destes compostos leva a formação de ácidos graxos de cadeia longa, que podem inibir a atividade das bactérias anaeróbias (Hanaki, 1981). 
Usando glicerol, a produção de hidrogênio não foi detectada nos frascos durante o tempo da fase experimental. A Figura 5.23 mostra que o tempo de execução do experimento provavelmente não foi o suficiente para o estabelecimento de produção de hidrogênio, principalmente porque o glicerol é uma molécula difícil de ser quebrada em cadeias menores formando ácidos graxos e liberando hidrogênio. O inóculo utilizado neste trabalho foi previamente adaptado para a degradação de carboidratos, o que certamente teve influência sobre a utilização de glicerol como fonte de carbono para a produção de hidrogênio. Embora hidrogênio não tenha sido detectado, a concentração de matéria orgânica na fase acidogênica apresentado na Figura 5.21 mostra uma pequena degradação de 12,6\% nos reatores contendo glicerol. O mesmo fenômeno foi observado nos reatores contendo esgoto sanitário, e suspeita-se que uma baixa quantidade de hidrogênio devem ter sido produzidos, mas não detectada com os métodos analíticos empregados.

A análise dos resultados apresentados na Figura 5.25 indica que atividade acidogênica ocorreu entre 24 e 36 h do experimento porque a produção de ácidos acético (4,08 $\left.\mathrm{mg} \mathrm{L}^{-1}\right)$, butírico $\left(7,49 \mathrm{mg} \mathrm{L}^{-1}\right)$, lático $\left(7,43 \mathrm{mg} \mathrm{L}^{-1}\right)$ e propiônico (38,81 $\left.\mathrm{mg} \mathrm{L}^{-1}\right)$ foi detectada. Estes resultados indicam que a rota de geração de ácido propiônico foi predominante no tempo de execução da fase acidogênica, o que não foi favorável para a produção de hidrogênio, pois a formação de ácido propiônico consome hidrogênio molecular do sistema. 


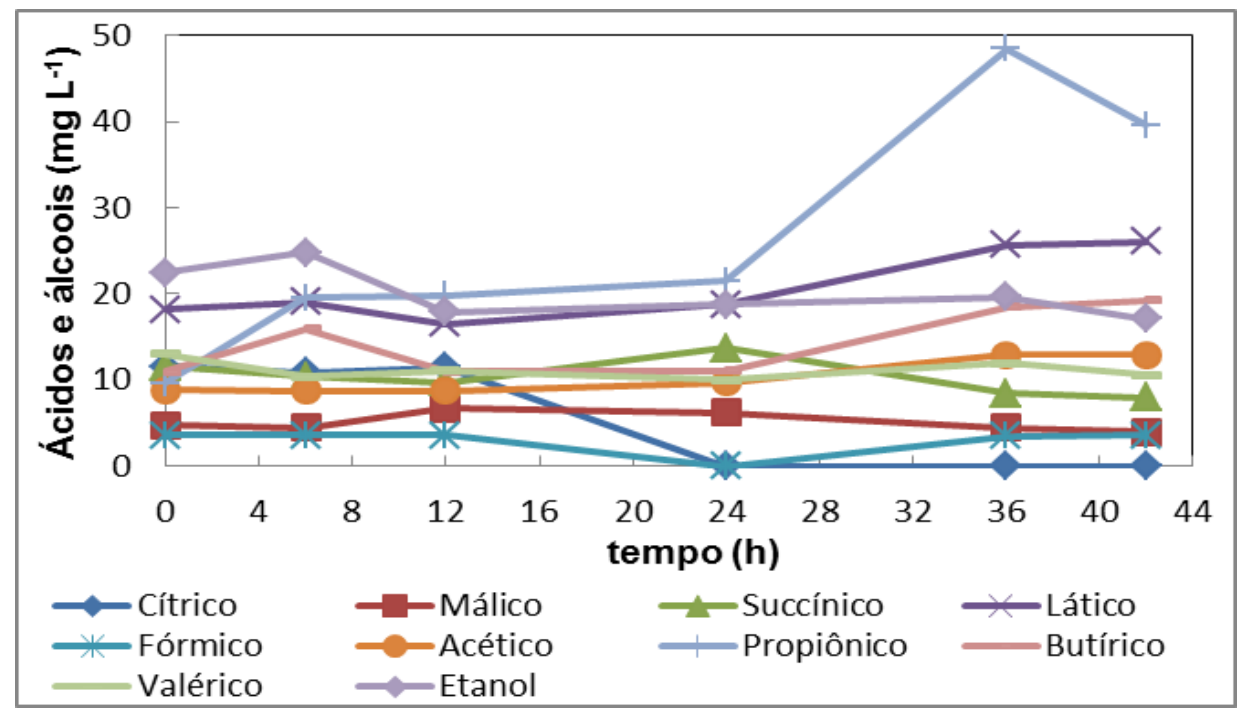

Figura 5.25 - Metabólitos solúveis produzidos pelo reator com glicerol na

Etapa 3.

De acordo com Barbirato et al. (1997), a produção de propionato a partir de glicerol pode ser realizada por três cepas de bactérias: Propionibacterium acidipropionici, Propionibacterium acnes e Clostridium propionicum. Além disso, Lay et al. (2000) relatam que Clostridium sp. é a espécie de microorganismo mais comumente identificada com a produção de hidrogênio em reatores biológicos, e essa constatação reforça a hipótese de que o inóculo retirado do reator de leito fixo e de fluxo ascendente provavelmente continha pelo menos uma dessas espécies de Clostridium capaz de produzir propionato a partir de glicerol.

Seifert et al.(2009) obtiveram produção de hidrogênio usando glicerol através de um processo de fermentação a $37^{\circ} \mathrm{C}$ e $\mathrm{pH}$ 6. Os experimentos foram conduzidos em reatores em batelada usando uma concentração de glicerol de $5 \mathrm{~g} \mathrm{~L}^{-1}$, uma concentração de inóculo de $2,3 \mathrm{~g} \mathrm{~L}^{-1} \mathrm{SSV}$ e $0,73 \mathrm{~g} \mathrm{~L}^{-1}$ de $\mathrm{N}$, resultando em 0,241 $\mathrm{L} \mathrm{H}_{2} \mathrm{~L}^{-1}$ ou $0,014 \mathrm{~L} \mathrm{H}_{2} \mathrm{~L}^{-1} \mathrm{~h}^{-1}$ com uma fase lag de 5,5 h e um rendimento de 0,198 $\mathrm{mol} \mathrm{H}_{2} \mathrm{~mol}^{-1}$ de glicerol. Além disso, no estudo de Ito et al. (2005), que foi 
realizado em reatores em batelada, a fase lag foi insignificante e os resultados da conversão de hidrogênio foram ainda melhores, com um rendimento de 1,05 mol $\mathrm{H}_{2}$ mol $^{-1}$ glicerol com a concentração inicial de 5,0 g L ${ }^{-1}$ glicerol.

Em comparação com o trabalho de Seifert et al. (2009) e Ito et al. (2005), notou-se que houve limitações no experimento reportado neste trabalho. Entre elas a concentração de glicerol, que foi cerca de $0,3 \mathrm{mg} \mathrm{L}^{-1}$, e a concentração de inóculo de 422,5 mg L ${ }^{-1}$ SSV. É provável que essas diferenças na concentração da fonte de carbono, concentração de biomassa, tipo de inóculo e da duração da fase acidogênica tenham influenciado a produção de hidrogênio a partir de glicerol.

O uso de água residuária de parboilização de arroz como substrato para produção de hidrogênio resultou em um potencial de produção de 6,82 mL $\mathrm{H}_{2}$, com a geração de acetato e succinato, principalmente, como metabólitos solúveis (com picos de produção em t $=6$ h e t $=12$ h, respectivamente ) (Figura 5.26).

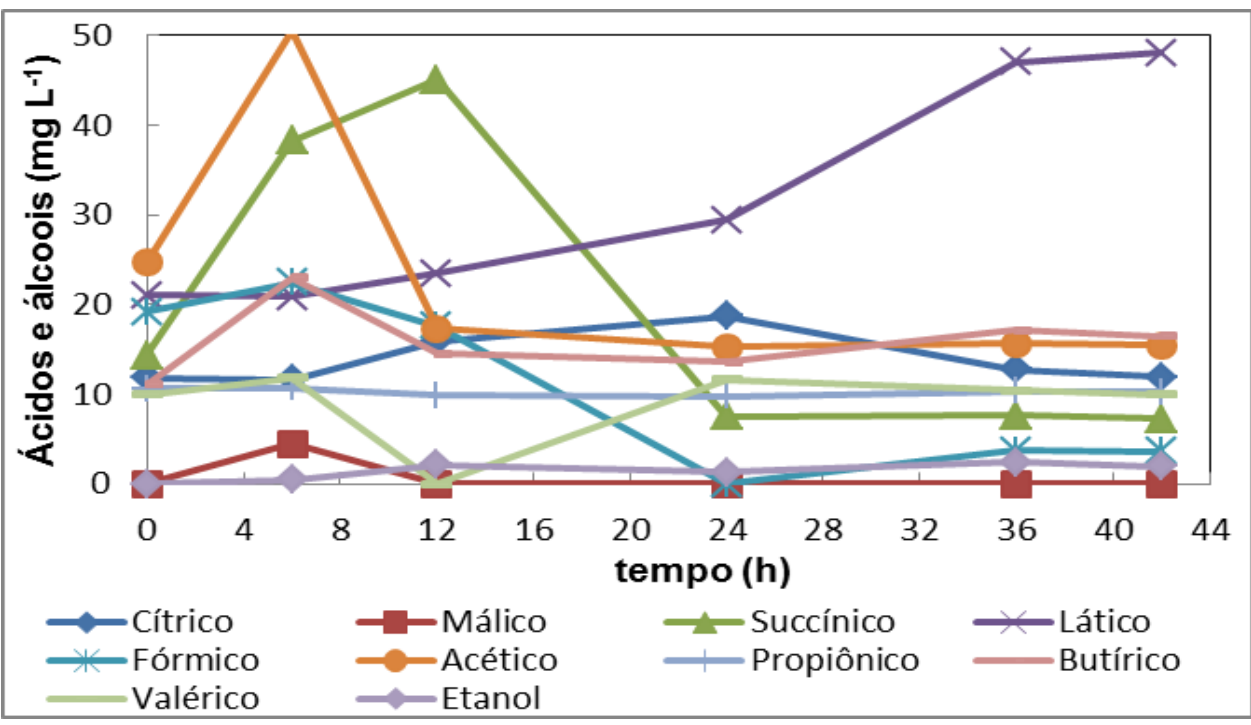

Figura 5.26 - Metabólitos solúveis produzidos pelo reator com água residuária da parboilização de arroz na Etapa 3. 
Sabe-se que o hidrogênio é liberado ao mesmo tempo que acetato ou butirato são produzidos, conforme mostrado nas Reações 5.4 e 5.5. Entretanto, a geração elevada de succinato simultaneamente com a produção de hidrogênio (Figura 5.26) sugere que uma via metabólica alternativa poderia estar ocorrendo. Se a glicose for considerada como o principal carboidrato gerado pela hidrólise ocorrida na parboilização de arroz, então pode-se propor a reação Reação 5.2, que descreveria superficialmente essa conversão metabólica.

$\mathrm{C}_{6} \mathrm{H}_{12} \mathrm{O}_{6}+2 \mathrm{H}_{2} \mathrm{O}=\mathrm{C}_{4} \mathrm{H}_{6} \mathrm{O}_{4}+2 \mathrm{CO}_{2}+5 \mathrm{H}_{2}$

Reação 5.2

$\Delta \mathrm{G}_{0}=-179.99 \mathrm{~kJ} \mathrm{~mol}^{-1}$

É provável que o aumento do lactato durante o ensaio não esteja relacionado com a via de produção de hidrogênio, o que é apoiado pelo estudo de Argun et al. (2008) no qual foi mostrado que a produção de lactato como produto final não libera hidrogênio.

Neste experimento com a água residuária de parboilização de arroz, obteve-se 14,66 mL $\mathrm{H}_{2} \mathrm{~g}^{-1} \mathrm{SV}$ com um rendimento de 23,90 $\mathrm{mL} \mathrm{H}_{2} \mathrm{~g}^{-1}$ DQO. Comparando os resultados obtidos neste trabalho com os do experimento conduzido por Okamoto et al. (2000) em reatores em batelada a $37^{\circ} \mathrm{C}$ inoculados com lodo anaeróbio pré-tratado e meio específico, esses autores atingiram 19,3 $\mathrm{mL} \mathrm{H}_{2} \mathrm{~g}^{-1} \mathrm{SV}$ e $16,8 \mathrm{~mL} \mathrm{H} \mathrm{g}^{-1}$ DQO com 15\% de sólidos totais (como conteúdo de arroz). Embora estes resultados pareçam semelhantes, o maior rendimento de hidrogênio obtido neste trabalho provavelmente está relacionado à hidrólise térmica envolvida no processo de parboilização de arroz, que pode ter causado a conversão de amido em glicose, 
facilitando assim a fase posterior de produção de hidrogênio. Esta hipótese pode ser reforçada considerando-se o maior valor da constante de consumo de carboidratos encontrados neste estudo com água residuária da parboilização de arroz, conforme pode ser visto na Tabela 5.1.

Diferentemente, nos experimentos de Okamoto et al. (2000), o substrato foi formado por partículas de arroz em vez de uma fonte de carbono solubilizado. Dessa forma, o amido, que é o principal carboidrato nos grãos de arroz precisava ser hidrolisado antes de ser transformado em um substrato prontamente disponível para a geração de hidrogênio.

Usando pasta de arroz como matéria-prima para produção de hidrogênio, Fang et al. (2006) obtiveram 248 mL $\mathrm{H}_{2}$ a uma taxa de produção de hidrogênio de 11 $\mathrm{mL} \mathrm{h}^{-1}$. O substrato continha $5,5 \mathrm{~g} \mathrm{~L}^{-1}$ em carboidratos e foi degradado a $37^{\circ} \mathrm{C}$, com pH de 5,5 por um inóculo obtido de um digestor anaeróbio contendo 566,66 mg L ${ }^{-1}$ SSV. O rendimento de hidrogênio obtido nestas condições foi de $300 \mathrm{~mL} \mathrm{H}_{2} \mathrm{~g}^{-1}$ carboidratos, o que é muito maior do que os 131,15 $\mathrm{mL} \mathrm{H}_{2} \mathrm{~g}^{-1}$ carboidratos obtidos neste trabalho.

É provável que a razão $\mathrm{S} / \mathrm{X}$ tenha contribuído grandemente para esses resultados, pois essa relação era de 9,71 no estudo de Fang et al. (2006), enquanto que neste trabalho foi de 0,11 . Chen et al. (2006) observaram que a razão S/X ideal para a produção de hidrogênio a partir de sacarose foi de 7,3 g DQO g ${ }^{-1}$ SSV. Estes parâmetros mostraram que a relação S/X utilizado por Fang et al. (2006) estava mais próxima do valor ótimo encontrado por Chen et al. (2006) e explica os resultados de Fang et al. (2006). 
Nos frascos contendo vinhaça, o hidrogênio foi produzido a $0,84 \mathrm{~mL} \mathrm{~h}^{-1}$, atingindo um potencial de produção de hidrogênio (P) de 6,25 mL. A alta velocidade de produção de hidrogênio $\left(\mathrm{R}_{\mathrm{m}}\right)$, juntamente com a elevada degradação da matéria orgânica $\left(0,0142 \mathrm{~h}^{-1}\right)$ provavelmente estavam relacionadas com o aumento de SSV

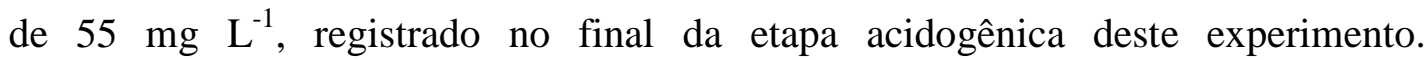
É provável que os compostos desta água residuária tenham favorecido o desenvolvimento de microorganismos produtores de hidrogênio, o que pode ser reforçado pela eficácia da produção de hidrogênio pela biomassa utilizada, que foi de 21,93 $\mathrm{mL} \mathrm{H}_{2} \mathrm{~g}^{-1} \mathrm{SSV}$, a mais alta entre os substratos avaliados.

De acordo com a Figura 5.27, o metabolismo assumido pelos microrganismos envolvidos na produção de hidrogênio a partir da vinhaça parece estar associado com a via de produção dos ácidos acético e butírico, pois foi detectada, principalmente, a geração de 22,44 mg $\mathrm{L}^{-1}$ e 17,24 $\mathrm{mg} \mathrm{L}^{-1}$ de ácido acético e ácido butírico, respectivamente. Esta razão de $\mathrm{HAc} / \mathrm{HBu}$ de 1,3 foi consistente com os bons resultados relativos a geração de hidrogênio obtido com vinhaça, pois o melhor rendimento de produção de hidrogênio a partir de carboidratos pode ser alcançado com razões HAc/HBu maiores que 1 (Khanal et al., 2004). 


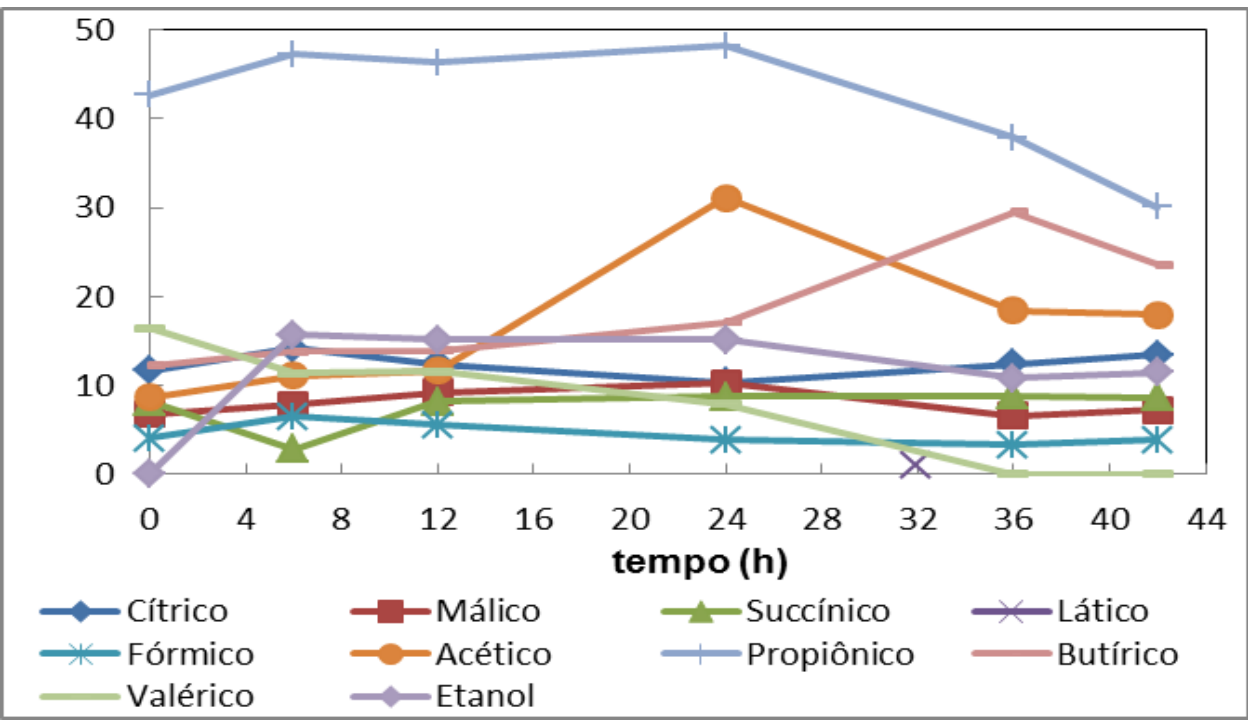

Figura 5.27 - Metabólitos solúveis produzidos pelo reator com vinhaça na Etapa 3.

Vale ressaltar que a relação $\mathrm{HAc} / \mathrm{HBu}$ não deve ser considerada isoladamente, porque caso haja geração significativa de produtos finais, tais como etanol ou ácido propiônico, o rendimento de produção de hidrogênio será baixo, mesmo com elevadas razões $\mathrm{HAc} / \mathrm{HBu} .$.

Neste trabalho foi detectada a geração de $15,70 \mathrm{mg} \mathrm{L}^{-1}$ de etanol, o que certamente afetou a produção de hidrogênio como proposto é por Sreethawong et al. (2010) e descrito pela Reação 5.3.

$\mathrm{C}_{6} \mathrm{H}_{12} \mathrm{O}_{6} \rightarrow 2 \mathrm{CH}_{3} \mathrm{CH}_{2} \mathrm{OH}+2 \mathrm{CO}_{2}$ Reação 5.3

Com relação à remoção de matéria orgânica, foi possível obter a eficiência de 42,72\%, o que está dentro da faixa de 29,1 a 56,5\% alcançada por Mohan et al. (2008). A elevada remoção de matéria orgânica relatada por Mohan et al. (2008) está provavelmente relacionada com a alta biodegradabilidade da vinhaça. Buitrón et 
al. (2010), afirmam que a vinhaça é geralmente composta por uma concentração de matéria orgânica entre 19,8 e 20,9 g L ${ }^{-1} \mathrm{DBO}_{5}$ e entre 29,9 e 30,5 g DQO L ${ }^{-1}$; uma concentração de fenol entre 44 e $81 \mathrm{mg} \mathrm{L}^{-1}$, uma concentração de sulfato de 915 mg $\mathrm{L}^{-1}$, uma concentração de $\mathrm{N}-\mathrm{NH}_{3}$ de $110 \mathrm{mg} \mathrm{L}^{-1}$ e um $\mathrm{pH}$ variando de 3,2 a 4,0. Além disso, de acordo com os mesmos autores, a relação $\mathrm{DBO}_{5} / \mathrm{DQO}$ situa-se geralmente em torno de 0,67, indicando que a matéria orgânica pode ser facilmente biodegradada (Tchobanoglous et al., 2003)

Como era esperado, a solução de sacarose produziu a maior quantidade de hidrogênio, pois possuía o maior teor de carboidratos (327 $\mathrm{mg} \mathrm{L}^{-1}$ ) entre os efluentes testados. O valor da constante cinética aparente de degradação de carboidratos da batelada contendo sacarose (Tabela 5.1) foi relativamente baixo quando comparado com aqueles estimados para a água residuária de parboilização de arroz e vinhaça. Sugere-se que devido ao fato desses outros substratos apresentarem concentrações significativamente mais baixas de carboidratos, tenha sido necessário menos tempo para o seu consumo, resultando em velocidades mais altas de degradação. Chen et al. (2006), que usaram reatores em batelada de $250 \mathrm{~mL}$ à $36^{\circ} \mathrm{C}, \mathrm{pH}$ de 5,5 e 0,3 $\mathrm{g} \mathrm{L}^{-1}$ DQO (em sacarose), obtiveram $2 \mathrm{~mL}$ de produção de hidrogênio. De acordo com a Tabela 5.1, este valor é substancialmente menor do que o obtido neste estudo. Por outro lado, observou-se menor fase de lag (6 h) e maior rendimento de hidrogênio (45 mL H $\mathrm{H}^{-1}$ DQO) em seu trabalho.

A fase lag mais longa e o menor rendimento de produção específica de hidrogênio em relação àquele obtido por Chen et al. (2006) estão provavelmente relacionados com a razão S/ X elevada utilizada neste trabalho $(0,86)$ em comparação com a razão S/X de 0,5 usada no estudo de Chen et al. (2006). De acordo com estes 
autores, a sacarose e outros substratos que consistem de carboidratos puros, alcançam melhor desempenho em termos de produção de hidrogênio com razões S/X menores. Apesar da maior produção de hidrogênio obtida neste trabalho, o rendimento de hidrogênio foi cerca de 44\% inferior ao alcançado por Chen et al. (2006). Acredita-se que a presença de microorganismos produtores de álcoois, tais como Klebsiella sp., no inóculo, podem ter convertido a fonte de carbono em etanol e outros solventes em vez de liberar o hidrogênio no biogás. Esta conjectura pode ser fundamentada pelo estudo de Fernandes et al. (2010), que provou a existência de Klebsiella sp. em reatores anaeróbios que foram operados sob as mesmas condições aplicadas para produzir o inóculo utilizado neste experimento. Além do etanol, ácido propiônico, que também é desfavorável para a produção de hidrogênio, foi gerado, consumindo o hidrogênio do sistema, assim como mostra a Reação 5.4. (Antonopoulou et al. 2008).

$\mathrm{C}_{6} \mathrm{H}_{12} \mathrm{O}_{6}+2 \mathrm{H}_{2} \rightarrow 2 \mathrm{CH}_{3} \mathrm{CH}_{2} \mathrm{COOH}+2 \mathrm{H}_{2} \mathrm{O}$

Reação 5.4

A Figura 5.28 mostra que os principais metabólitos solúveis produzidos com este substrato foram o etanol (54,57 $\left.\mathrm{mg} \mathrm{L}^{-1}\right)$, o ácido acético $\left(51,37 \mathrm{mg} \mathrm{L}^{-1}\right)$, o ácido butírico (28,75 $\left.\mathrm{mg} \mathrm{L}^{-1}\right)$ e ácido propiônico $\left(25,12 \mathrm{mg} \mathrm{L}^{-1}\right)$. Esta composição de metabólitos solúveis foi similar à relatada no estudo de Fernandes et al. (2010). 


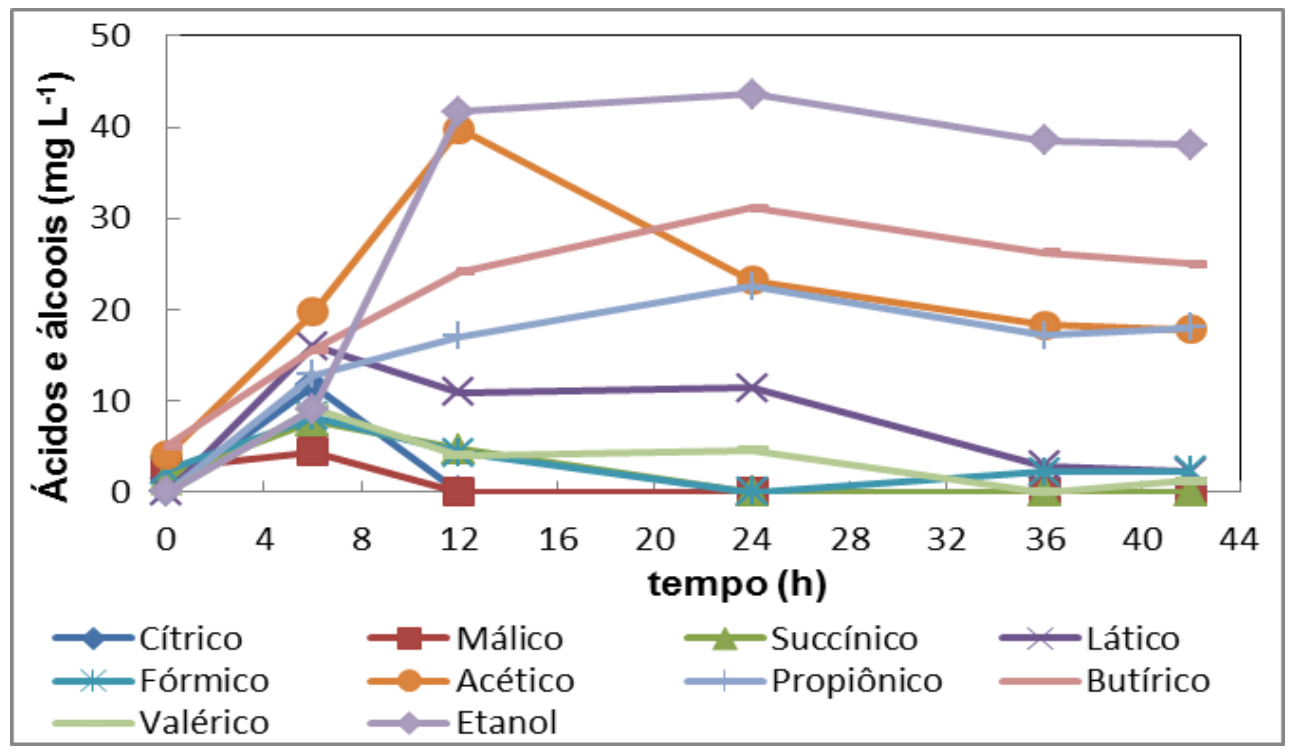

Figura 5.28 - Metabólitos solúveis produzidos pelo reator com sacarose na Etapa 3.

Apesar da geração de etanol, a predominância de acetato e butirato como metabólitos solúveis entra em concordância com os achados de Minton (1989), que afirmou que esta via é encontrada em aproximadamente 50\% de todos os clostridiums que foram isolados até o momento. Além disso, o $\Delta \mathrm{G}^{0}$ das reações que envolvem a conversão de carboidratos em hidrogênio pelas vias do acetato e butirato é muito favorável, como mostrado nas Reações 5.5 e 5.6.

$\mathrm{C}_{6} \mathrm{H}_{12} \mathrm{O}_{6}+2 \mathrm{H}_{2} \mathrm{O} \rightarrow 2 \mathrm{CH}_{3} \mathrm{COOH}+2 \mathrm{CO}_{2}+4 \mathrm{H}_{2} \uparrow$ Reação 5.5

$\Delta \mathrm{G}_{0}=-215.69 \mathrm{~kJ} \mathrm{~mol}^{-1}$ (Thauer, 1976)

$\mathrm{C}_{6} \mathrm{H}_{12} \mathrm{O}_{6}+2 \mathrm{H}_{2} \mathrm{O} \rightarrow \mathrm{CH}_{2} \mathrm{CH}_{2} \mathrm{CH}_{2} \mathrm{COOH}+2 \mathrm{CO}_{2}+2 \mathrm{H}_{2} \uparrow$

Reação 5.6

$\Delta \mathrm{G}_{0}=-254.80 \mathrm{~kJ} \mathrm{~mol}^{-1}$ (Levin et al., 2004) 
A Tabela 5.2 apresenta um balanço de massa de feito para os reatores em batelada para confirmar a plausibilidade dos resultados obtidos com o experimento. Os resultados apresentados na Tabela 5.2 mostram que houve poucos equivalentes faltando. A exceção ocorreu com os frascos contendo glicerol e água residuária de parboilização de arroz, cuja falta de equivalência no balanço de DQO atingiu 16,00 e $17,55 \%$, respectivamente.

A principal razão para o déficit no balanço de massa pode ser atribuída à formação de metabólitos não detectados ou a presença de outros sumidouros de elétrons. No entanto, devido a não-detecção de $\mathrm{CH}_{4}$ ou $\mathrm{H}_{2} \mathrm{~S}$, é improvável que os equivalentes faltantes tenham surgido devido ao fluxo de elétrons em direção a esses dois aceptores envolvidos no processo anaeróbio. É mais provável que alguns metabólitos solúveis que não foram monitorados (por exemplo, alguns ácidos graxos ou solventes) tenham contribuído para a falta de equivalência. 
Tabela 5.2 - Balanço de massa (em termos de DQO) para os resultados obtidos na etapa acidogênica dos substratos avaliados.

\begin{tabular}{|c|c|c|c|c|c|c|c|c|c|c|c|c|c|c|c|c|c|c|}
\hline \multirow[b]{2}{*}{ Substrato } & \multirow[b]{2}{*}{$\begin{array}{l}\text { DQO } \\
\text { carb } \\
\text { (mg } \\
\text { DQO) }\end{array}$} & \multirow[b]{2}{*}{$\begin{array}{l}\text { DQO } \\
\text { b } \\
\text { H2 } \\
\text { (mg } \\
\text { DQO) }\end{array}$} & \multirow[b]{2}{*}{ Hci } & \multirow[b]{2}{*}{ HMa } & \multirow[b]{2}{*}{$\mathrm{HSu}$} & \multirow[b]{2}{*}{ Hla } & \multirow[b]{2}{*}{ HFo } & \multicolumn{3}{|c|}{$\begin{array}{c}\mathrm{DQO}_{\mathrm{pms}}{ }^{\mathrm{c}} \\
(\mathrm{mg} \mathrm{DQO})\end{array}$} & \multirow[b]{2}{*}{ Hbu } & \multirow[b]{2}{*}{ Isov } & \multirow[b]{2}{*}{$\mathrm{HVa}$} & \multirow[b]{2}{*}{$\mathrm{HCa}$} & \multirow[b]{2}{*}{$\mathrm{EtOH}$} & \multirow[b]{2}{*}{$\begin{array}{l}\mathrm{DQO} \\
\text { d } \\
\text { soma } \\
\text { (mg } \\
\text { DQO) }\end{array}$} & \multirow[b]{2}{*}{$\begin{array}{l}\text { DQO } \\
\text { e } \\
\text { total } \\
\text { (mg } \\
\text { DQO) }\end{array}$} & \multirow[b]{2}{*}{$\begin{array}{l}\text { Equivalência } \\
\text { (\%) }\end{array}$} \\
\hline & & & & & & & & HAc & $\mathrm{HPr}$ & Isob & & & & & & & & \\
\hline Esgoto & 3.0 & 0 & 0 & 3.7 & 7.0 & 20.0 & 1.2 & 30.8 & 13.9 & 20.1 & 35.0 & 28.4 & 23.9 & 0.0 & 7.7 & 195.7 & 223.0 & 12.2 \\
\hline Glicerol & 5.1 & 0 & 0 & 3.2 & 7.9 & 27.3 & 1.2 & 13.7 & 73.2 & 0 & 33.4 & 11.5 & 26.1 & 0 & 40.8 & 252.8 & 290.3 & 16.0 \\
\hline A.R Arroz & 0.0 & 3.3 & 8.4 & 0 & 7.2 & 50.1 & 1.3 & 16.6 & 15.6 & 18.6 & 31.1 & 0 & 22.8 & 0 & 5.1 & 173.7 & 210.7 & 17.5 \\
\hline Vinhaça & 13.9 & 2.9 & 8.2 & 4.7 & 8.4 & 19.1 & 1.1 & 19.6 & 57.2 & 0 & 75.3 & 0 & 0 & 0 & 22.5 & 227.4 & 233.3 & 2.5 \\
\hline Sacarose & 9.1 & 5.1 & 0 & 0 & 0 & 16.9 & 2.8 & 38.7 & 28.9 & 0 & 85.8 & 0 & 38.2 & 0 & 103.3 & 318.9 & 328.8 & 3.0 \\
\hline
\end{tabular}

$\mathrm{aDQO}_{\text {carb : }}$ DQO dos carboidratos residuais.

${ }^{\mathrm{b}} \mathrm{DQO}_{\mathrm{H} 2}$ : mg DQO do $\mathrm{H}_{2}$ produzido, calculado como mol $\mathrm{H}_{2}$ × 16 g DQO mol $\mathrm{H}_{2}^{-1}$ x $1000 \mathrm{mg} \mathrm{g}^{-1}$.

${ }^{\mathrm{c}} \mathrm{DQO}_{\mathrm{pms}}$ : DQO dos produtos metabólicos solúveis (PMS).

${ }^{\mathrm{d}} \mathrm{DQO}_{\text {soma }}-\mathrm{DQO}_{\mathrm{H} 2}$ : A soma de DQO dos carboidratos residuais e a DQO dos (PMS) - DQO envolvida na produção de hidrogênio.

${ }^{\mathrm{e}} \mathrm{DQO}_{\text {total }}$ : DQO medida no reator.

${ }^{\mathrm{f}}$ Calculado por $\left[\left(1-\left(\mathrm{DQO}_{\text {soma }}\right) /\left(\mathrm{DQO}_{\text {total }}\right)\right) \times 100 \%\right]$. 


\subsection{2 - Potencial de produção de metano a partir dos produtos solúveis gerados na produção de hidrogênio}

Nos frascos contendo sacarose e glicerol foi encontrada a maior concentração de matéria orgânica (Figura 5.29). No caso da sacarose, a geração elevada de propionato e etanol aprisionou quantidades consideráveis de hidrogênio nestes compostos de alto peso molecular, o que não permitiu a redução significativa da DQO. Nos ensaios com glicerol a alta concentração de matéria orgânica deveu-se à menor velocidade de degradação observada durante a primeira fase do experimento.

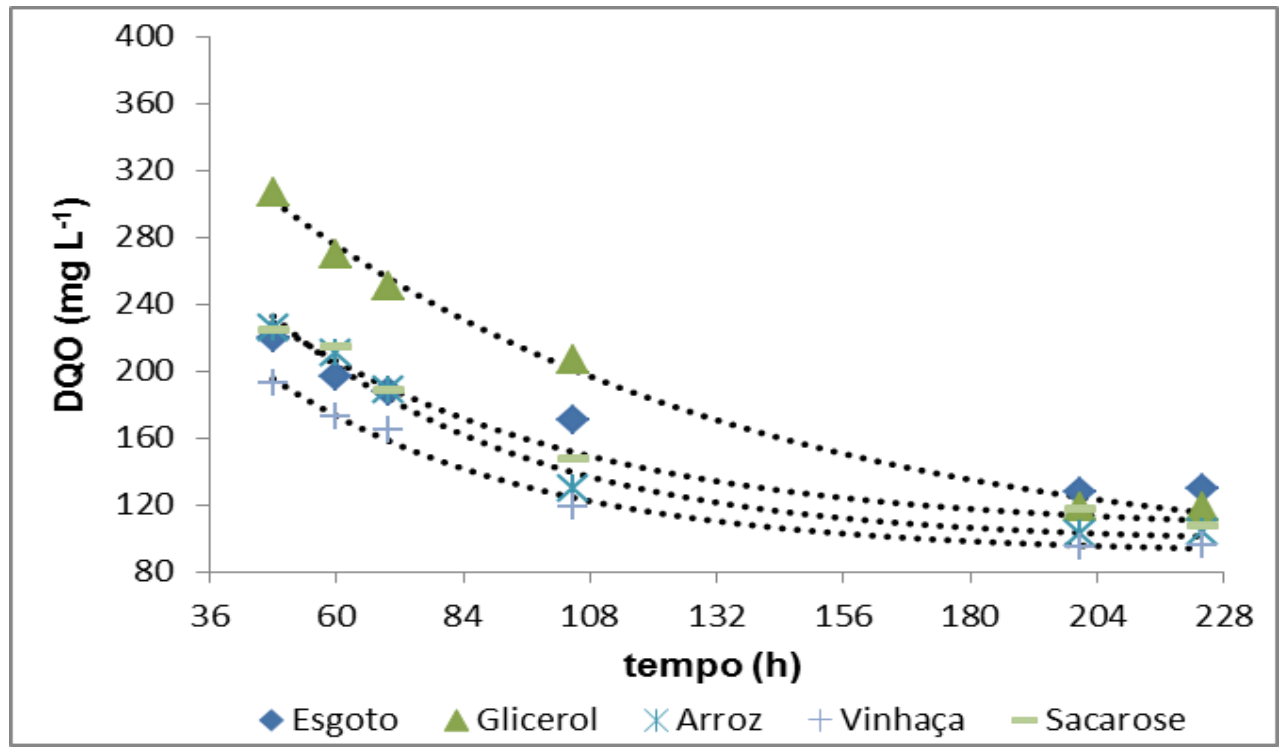

Figura 5.29 - Remoção da DQO dos reatores metanogênicos da Etapa 3; (...) decaimento exponencial de primeira ordem.

Nesta etapa do procedimento experimental foi possível verificar a diminuição do teor de matéria orgânica em todos os efluentes testados. Os frascos contendo água residuária de parboilização de arroz apresentaram 54,3\% de eficiência de remoção de 
matéria orgânica e aqueles contendo glicerol mostraram eficiência de remoção de 61,1\%, sendo assim os maiores valores de eficiência de degradação de matéria orgânica medidos nesta fase. A vinhaça e o esgoto sanitário apresentaram remoções de matéria orgânica de 50,7 e 41,9\%, respectivamente.

De acordo com a Tabela 5.3, as constantes cinéticas aparentes de degração da matéria orgânica $\left(\mathrm{k}_{2},\right)$ foram elevadas nos ensaios com glicerol $\left(0,0059 \mathrm{~h}^{-}\right.$ $\left.{ }^{1}\right)$, vinhaça $\left(0,0052 \mathrm{~h}^{-1}\right)$ e água residuária de parboilização de $\operatorname{arroz}\left(0,0050 \mathrm{~h}^{-1}\right)$, o que se refletiu na produção de metano nesses frascos.

Tabela 5.3 - Cinética de primeira ordem para remoção de DQO e valores dos parâmetros cinéticos obtidos com o modelo cinético de primeira ordem para a produção de metano.

\begin{tabular}{lcccccccr}
\hline Substrato & $\begin{array}{c}\mathrm{C}_{\mathrm{DQO}} \\
\left(\mathrm{mg} \mathrm{L}^{-1}\right)\end{array}$ & $\begin{array}{c}\mathrm{DQO} \\
\mathrm{k}_{2}{ }^{-1}\end{array}$ & $\mathrm{R}^{2}$ & $\begin{array}{c}\mathrm{X} \\
\left(\mathrm{g} \mathrm{L}^{-1} \mathrm{SSV}\right)\end{array}$ & $\begin{array}{c}\mathrm{K}_{\mathrm{G}}^{\prime} \\
\left(\mathrm{h}^{-1}\right)\end{array}$ & $\begin{array}{c}\text { Metano } \\
\mathrm{G}_{\mathrm{M}} \\
(\mathrm{mL})\end{array}$ & $\begin{array}{c}\mathrm{K}_{\mathrm{G}} \\
\left(\mathrm{mL} \mathrm{g} \mathrm{SSV}^{-1} \mathrm{~h}^{-1}\right)\end{array}$ & $\mathrm{R}^{2}$ \\
\hline Esgoto & 220 & 0.0033 & 0.97 & $* 0.573$ & - & $* 10.2$ & - & - \\
Glicerol & 307 & 0.0059 & 0.99 & 0.585 & 0.0074 & 49.9 & 0.013 & 0.99 \\
A.R Arroz & 226 & 0.0050 & 0.97 & 0.667 & 0.0122 & 26.0 & 0.018 & 0.98 \\
Vinhaça & 193 & 0.0045 & 0.99 & 0.477 & 0.0071 & 49.3 & 0.015 & 0.97 \\
Sacarose & 304 & 0.0040 & 0.99 & 0.441 & 0.0103 & 19.0 & 0.023 & 0.99 \\
\hline
\end{tabular}

*Não apresentou grau de liberdade para ser ajustado pelo modelo.

A disponibilidade de carboidratos para todos os frascos foi insignificante, como demonstrado na Figura 5.30. Este resultado já era esperado, pois os carboidratos, lipídios e proteínas são hidrolisadas e quase totalmente degradados no início do processo de digestão anaeróbia, que ocorre durante a etapa acidogênica (Metcalf e Eddy, 2003). 


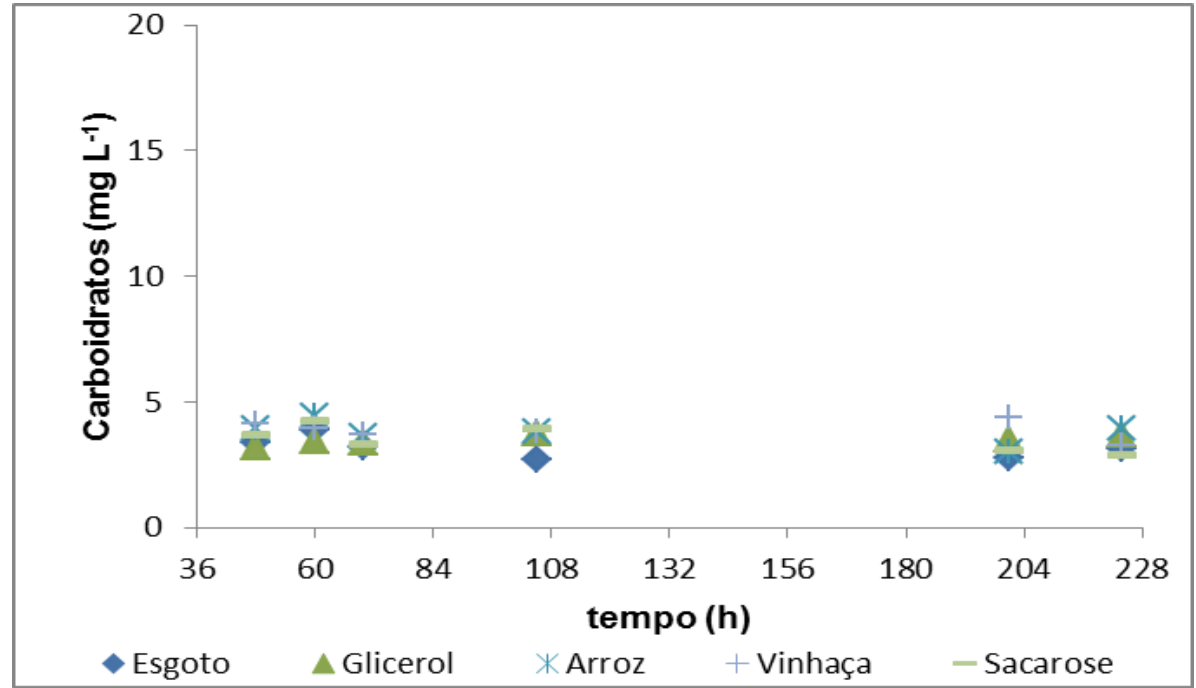

Figura 5.30 - Degradação de carboidratos nos reatores metanogênicos da Etapa 3.

Conforme mostra a Figura 5.31, os frascos contendo esgoto doméstico produziram cerca de 10,20 $\mathrm{mL}$ de $\mathrm{CH}_{4}$ após a maior fase lag observada dentre os substratos testados.

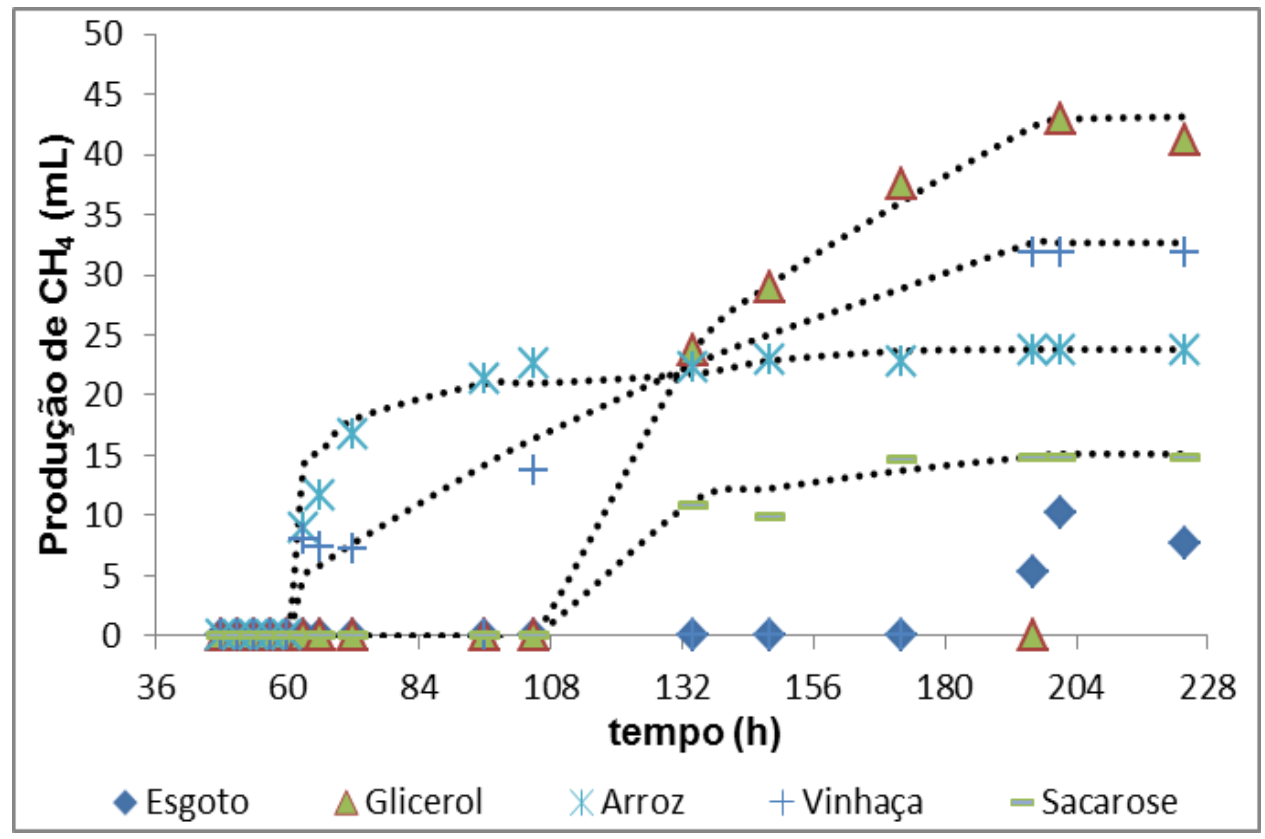

Figura 5.31 - Produção de metano a partir dos metabólitos solúveis da produção de hidrogênio; (...) modelo cinético de primeira ordem. 
A baixa produção de metano a partir de esgoto sanitário provavelmente esteve relacionada com a remoção de matéria orgânica e sua velocidade de degradação, que também foram as mais baixas entre os demais substratos, como mostrado na Tabela 5.3. É provável que a baixa degradação da matéria orgânica $(41,81 \%)$ ocorreu porque não havia nenhum composto facilmente biodegradável como carboidratos e nem mesmo compostos prontamente disponíveis como substratos para as arqueias metanogênicas. O perfil dos metabólitos solúveis apresentados na Figura 5.32 indicou que o esgoto doméstico já havia sofrido processo de degradação anterior ao seu uso como substrato neste estudo, o que é plausível porque o esgoto utilizado atravessava quilômetros de rede coletora antes de ser captado no poço de succção da área 2 da USP - São Carlos.

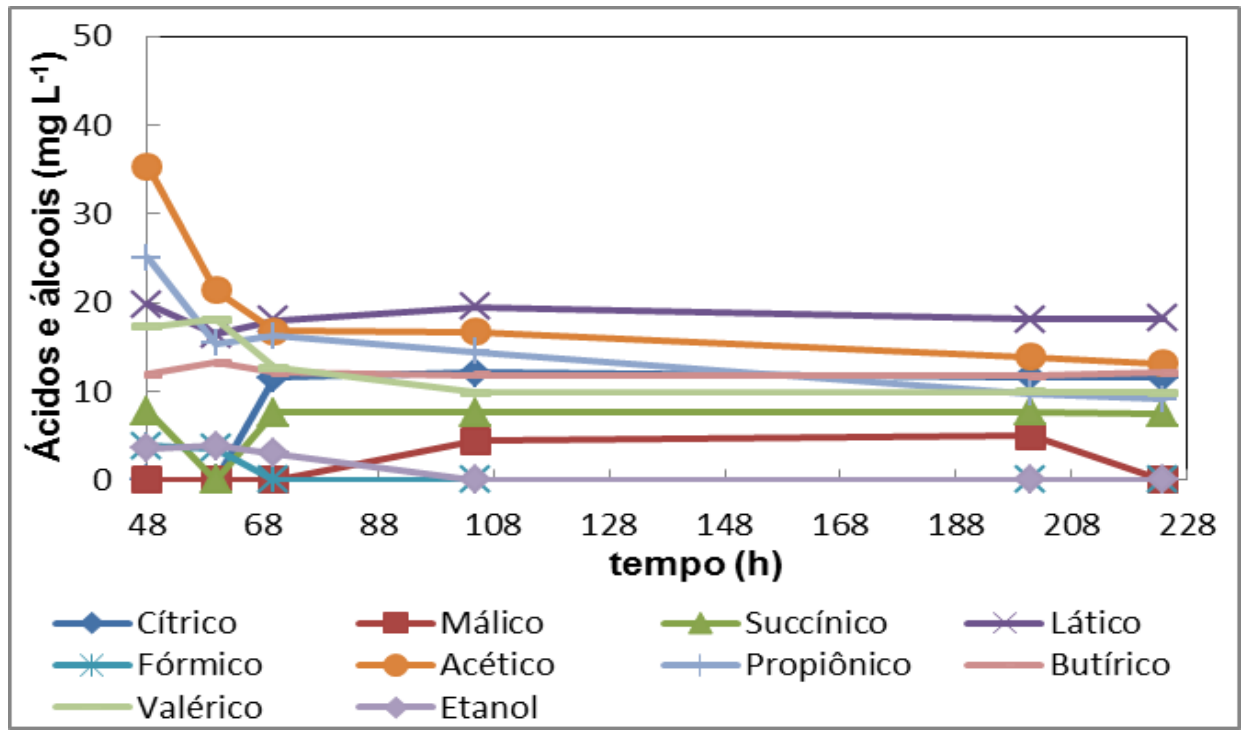

Figura 5.32 - Metabólitos solúveis do reator usando esgoto acidificado na Etapa 3.

Acerca dos metabólitos gerados utilizando esgoto sanitário (Figura 5.32), o início da etapa metanogênica rendeu 13,95 $\mathrm{mg} \mathrm{L}^{-1}$ de ácido acético, 9,71 $\mathrm{mg} \mathrm{L}^{-1}$ de ácido propiônico e ácidos succínico, láctico e valérico em menores quantidades. A 
diminuição na concentração de cada ácido, detectado em $\mathrm{t}=48 \mathrm{~h}$ indica que estes foram degradados como parte do processo de metanogênese (Gujer e Zehnder, 1983). Utilizando esgoto com características semelhantes às determinadas neste estudo, como uma DQO de 268,5 $\mathrm{mg} \mathrm{L}^{-1}$ e pH de 7,1, Gao et al. (2010) também obtiveram ácido acético como o principal metabólito solúvel. A concentração de ácido acético encontrado foi de $19,7 \mathrm{mg} \mathrm{L}^{-1}$ para um TDH de $8 \mathrm{~h}$ em um reator anaeróbio de leito fixo e fluxo ascendente (UAFB) de $6 \mathrm{~L}$, que foi mantido a $35^{\circ} \mathrm{C}$. A produção de metano obtida por Gao et al. (2010) foi de $187,8 \mathrm{~mL} \mathrm{~g}^{-1}$ de DQO removida, enquanto neste experimento esse valor foi de $111,06 \mathrm{~mL} \mathrm{CH}_{4} \mathrm{~g}^{-1}$ de DQO removida, o que pode ser visto como um bom resultado considerando o fato de que este estudo foi realizado em reatores descontínuos a $25^{\circ} \mathrm{C}$. De acordo com os resultados obtidos, o glicerol atingiu uma produção de metano de 49,9 mL, que foi a maior entre os substratos testados. Bom desempenho também foi observado com relação ao rendimento de metano (180,14 mL $\mathrm{CH}_{4} \mathrm{~g}^{-1}$ DQO), indicando que a matéria orgânica foi bem direcionada para o processo de metanização. Apenas a vinhaça apresentou maior rendimento de metano $(255,44 \mathrm{~mL}$ $\mathrm{CH}_{4} \mathrm{~g}^{-1} \mathrm{DQO}$ ), provavelmente devido à degradação rápida de todos os ácidos e etanol no início da fase metanogênica, que pode ser observada em $t=48$ h na Figura 5.35. Por outro lado, o glicerol mostrava conversão de matéria orgânica em ácidos com cerca de 72 h na fase metanogênica (Figura 5.33), o que contribuiu para a fase lag mais longa (86 h) na produção de metano. 


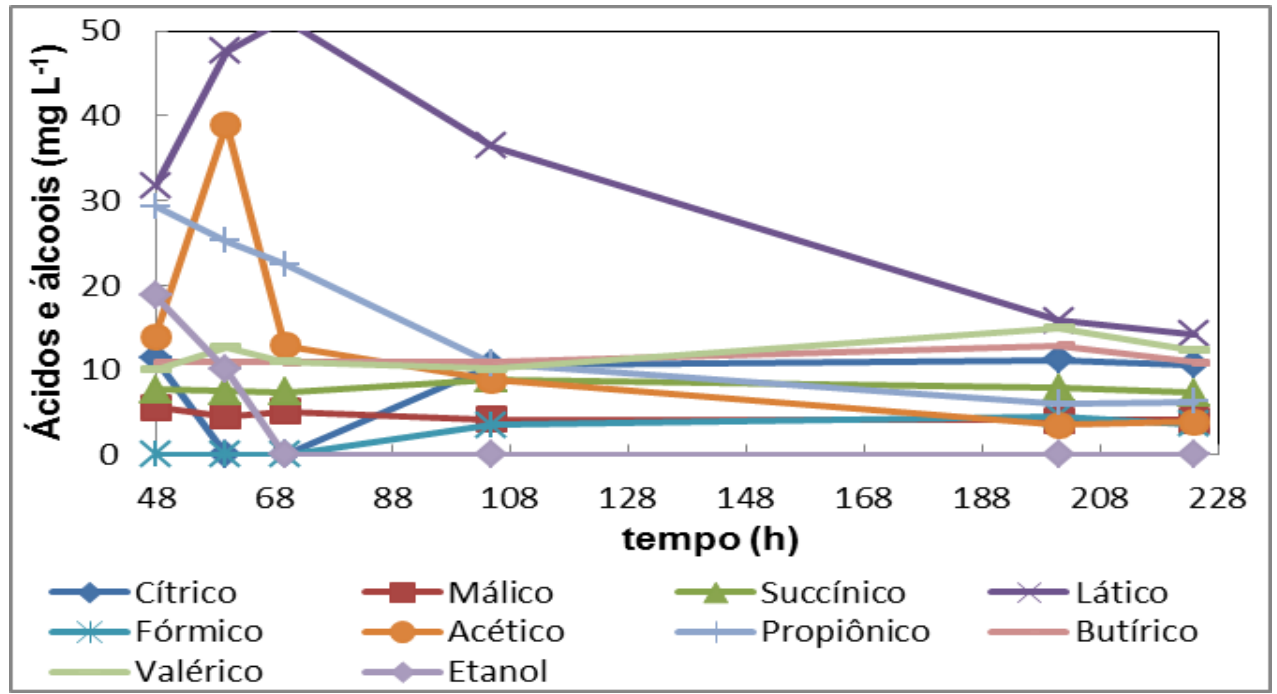

Figura 5.33 - Metabólitos solúveis do reator usando glicerol acidificado na Etapa 3.

Comparando-se com estudos anteriores sobre a metanização do glicerol, é possível obter valores mais elevados de rendimento de metano, como o relatado por López et al. (2009). Em seu estudo, a partir de glicerol de fabricação do biodiesel, reatores anaeróbios em batelada a $35{ }^{\circ} \mathrm{C}$ foram inoculados com biomassa metanogênica ativa não-granular (28400 mg $\mathrm{L}^{-1}$ SSV) de um reator anaeróbio tratando de águas residuárias urbanas em escala real. Estes pesquisadores obtiveram $288 \mathrm{~mL} \mathrm{CH}_{4} \mathrm{~g}^{-1}$ de DQO removida, o que é superior à 252,53 $\mathrm{mL} \mathrm{CH}_{4} \mathrm{~g}^{-1} \mathrm{DQO}$ removida obtida neste trabalho. Sugere-se que o inóculo e/ou a configuração do reator usado por López et al. (2009) foram fatores decisivos para a obtenção dos bons resultados na produção de metano. Neste ensaio com glicerol (Figura 5.33), um pico considerável de ácido lático $\left(19,61 \mathrm{mg} \mathrm{L}^{-1}, \mathrm{t}=70\right.$ h) foi observado, entretanto, após 70 h, uma diminuição na concentração deste ácido foi notada, que mais tarde estabilizou-se no final do ensaio. A concentração de ácido acético $\left(25,00 \mathrm{mg} \mathrm{L}^{-1}, \mathrm{t}=\right.$ $60 \mathrm{~h}$ ) se comportou de forma semelhante, sendo que o mesmo foi totalmente consumido até o final do experimento. O alto teor de matéria orgânica disponível em 
$\mathrm{t}=48 \mathrm{~h}$ (cerca de 307,38 $\mathrm{mg} \mathrm{L}^{-1}$ ) associado com a produção de ácido acético (subproduto utilizado pelas bactérias metanogênicas acetoclásticas) pode explicar os bons resultados observados para a produção de metano nos frascos com glicerol. Além disso, durante a fase metanogênica, não houve geração de ácido propiônico ou etanol. Ao contrário, esses compostos foram completamente convertidos, o que também ajuda a explicar o bom desempenho em relação à metanização.

A avaliação dos produtos da fase acidogênica como substrato para a fase metanogênica da água residuária de parboilização de arroz revelou uma produção volumétrica de metano de 26,00 mL a uma velocidade específica de geração de 0,018 $\mathrm{L} \mathrm{CH}_{4}$ gVSS$^{-1} \mathrm{~h}^{-1}$, que foi a maior obtida entre todos os efluentes testados. A biomassa metanogênica teve uma adaptação bem sucedida aos produtos finais da etapa acidogênica resultando em uma curta fase lag de 18 h, que foi semelhante à observada com a vinhaça. A dinâmica dos metabólitos solúveis apresentados na Figura 5.34 indica que o ácido lático pode ter sido convertido em uma mistura de ácido cítrico, propiônico, butírico e isovalérico. É provável que a metanogênese tenha ocorrido principalmente pela via acetoclástica porque uma diminuição contínua na concentração de ácido láctico e um aumento na de acético, propiônico, butírico e isovalérico foram observadas em $t=72$ h. Provavelmente a concentração de ácido acético ficou abaixo das concentrações de outros ácidos, porque ele estava sendo consumido ao mesmo tempo pela via acetoclástica, que manteve baixa concentração deste ácido no meio. A rápida inicialização na produção de biogás pode estar relacionada com o consumo de etanol ocorrido no início da fase metanogênica $(\mathrm{t}$ = 60 h). Além disso, mesmo em baixas concentrações, outros ácidos podem ter sido 
usados para formar metano (Campos et al., 1999).

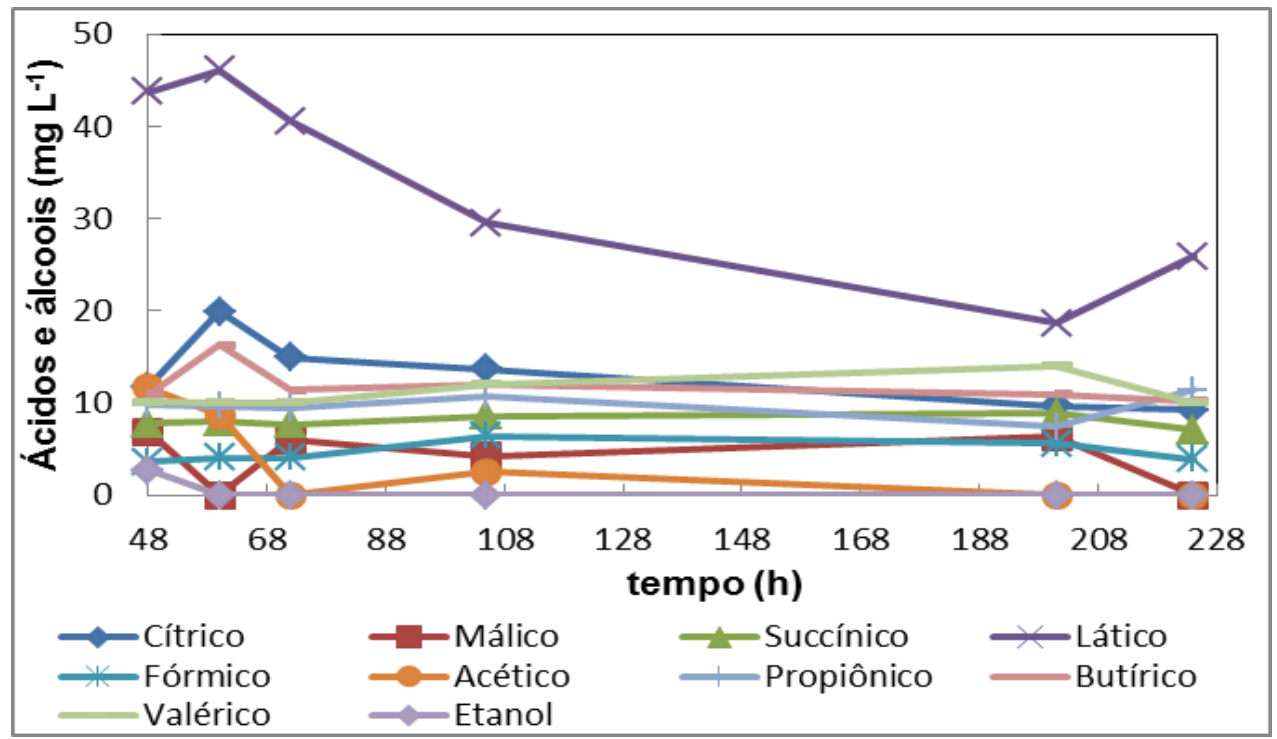

Figura 5.34 - Metabólitos solúveis do reator usando água residuária de parboilização de arroz acidificada na Etapa 3.

Utilizando palha de arroz para a produção de metano em frascos de 2,5 L à temperatura ambiente $\left(25^{\circ} \mathrm{C}\right)$, Lianhua et al. (2010) alcançaram a velocidade de produção de metano de $370 \mathrm{~mL} \mathrm{dia}^{-1}$ em 152 h (aproximadamente 6 dias) enquanto neste estudo, obteve-se de 23,80 $\mathrm{mL} \mathrm{CH}_{4}$ dia $^{-1}$ após 6 dias de experimento, o que é muito inferior ao valor obtido por Lianhua et al.(2010). Esta diferença pode ser explicada pela disponibilidade da fonte de carbono para cada ensaio. No estudo de Lianhua et al. (2010), a matéria orgânica disponível para metanização foi composta de 800 g de palha de arroz pré-tratados com teor de sólidos totais correspondente a 7,5\% em peso, enquanto neste estudo apenas $53 \mathrm{~mL}$ de água residuária de parboilização de arroz contendo uma concentração de sólidos insignificante foi diluída para a execução deste ensaio. 
A vinhaça rendeu a produção de metano de $49,3 \mathrm{~mL}$, resultando em 255,44 $\mathrm{mL} \mathrm{CH}_{4} \mathrm{~g}^{-1} \mathrm{DQO}$, que foi a maior entre os substratos testados. A ausência de compostos de cadeia longa sendo gerados, tais como ácido succínico, valérico e propiônico na fase metanogênica certamente contribuiu para o alto rendimento alcançado, principalmente porque a degradação dos ácidos de cadeia longa exigiria grandes quantidades de energia com conseqüente redução e atraso na produção de metano. A diminuição constante na concentração de ácido propiônico observada logo no início da fase metanogênica ocorreu, provavelmente, devido à conversão deste ácido em acetato ou hidrogênio, que são os doadores de elétrons para a formação de metano.

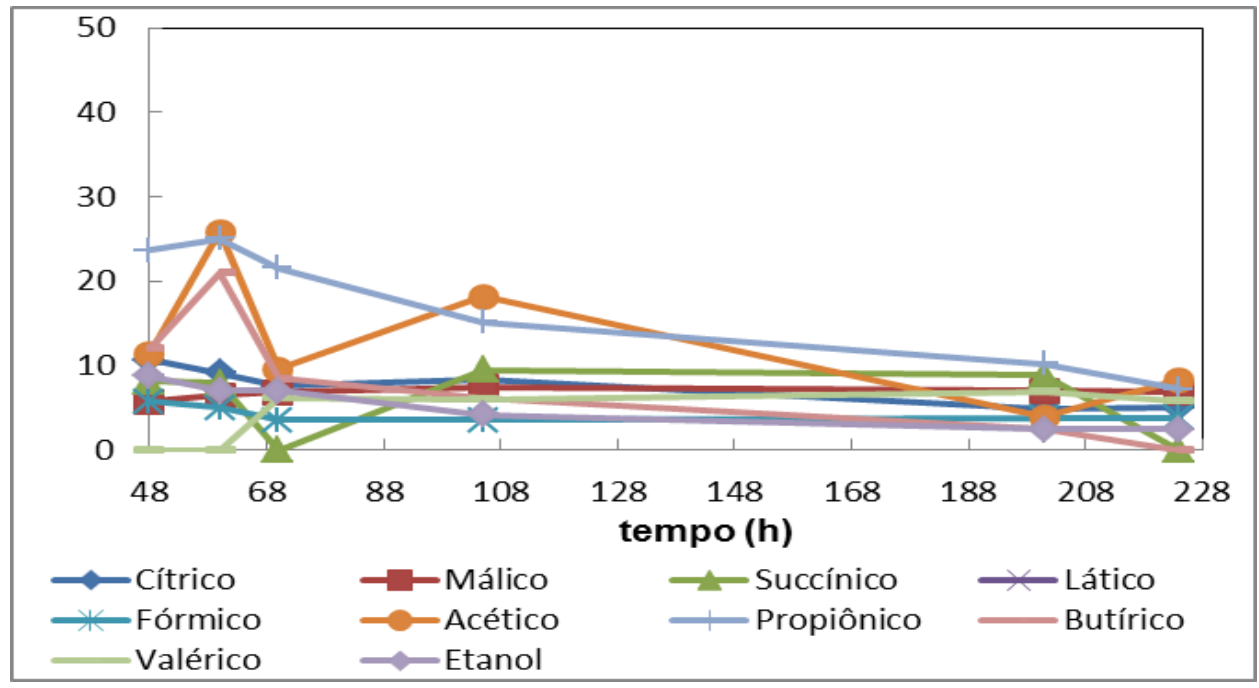

Figura 5.35 - Metabólitos solúveis do reator usando vinhaça acidificada na Etapa 3.

Neste trabalho, a eficiência de remoção de DQO obtida foi de 50,7\%, que se aproximou da eficiência de 69,2\% alcançada por Lalov et al. (2001) tratando vinhaça em um reator de leito fixo de $30 \mathrm{~mL}$ à temperatura de trabalho de $37{ }^{\circ} \mathrm{C}$. Os produtos finais da fase de acidogênese da sacarose aplicados à produção 
de metano renderam apenas 53,67 $\mathrm{mL} \mathrm{CH}_{4} \mathrm{~g}^{-1}$ DQO, com conseqüente baixa produção volumétrica de metano (19,0 mL).

Apesar da considerável velocidade de produção de metano, a fase lag observada nos frascos com solução de sacarose degradada foi de 57 h, o que representou a mais longa observada dentre os outros substratos. Este comportamento ocorreu, provavelmente, devido ao passo limitante envolvido na produção de acetato a partir do etanol gerado durante a fase acidogênica (Figura 5.36).

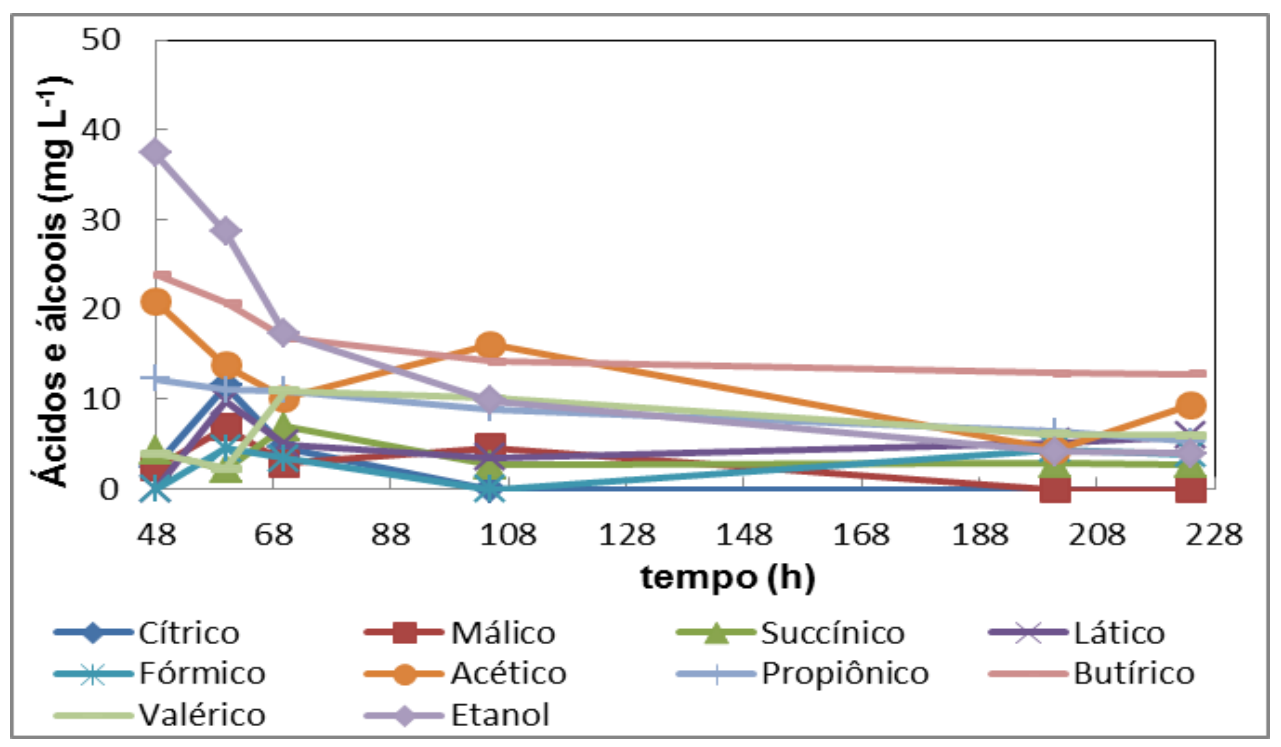

Figura 5.36 - Metabólitos solúveis do reator usando sacarose acidificada na Etapa 3.

Os outros ácidos graxos voláteis, como o ácido butírico, lático e propiônico, seguiram um padrão similar. Seus picos apareceram logo no início da fase metanogênica, apresentando um perfil de constante diminuição. Isto era esperado pois a etapa acetogênica consiste em reações intermediárias que produzem acetato através da oxidação de ácidos orgânicos, álcoois, hidrogênio ou redução de CO (Jones et al., 1983). 
Conforme mostrado na Figura 5.36, a concentração inicial elevada de metabólitos que se originaram durante a fase acidogênica pode ter requerido mais tempo para ser totalmente convertida em substratos para produção de metano. Sugere-se que a produção de metano foi obtida principalmente a partir da oxidação do etanol em acetato com a posterior metanogênese acetoclástica.

De acordo com o estudo de Jones et al. (1983) realizado em reatores em batelada contendo sacarose $\left(1,71 \mathrm{~g} \mathrm{~L}^{-1}\right)$, $\mathrm{pH}$ de 7,2 , temperatura de $37^{\circ} \mathrm{C}$ e utilizando consórcios de M. barkeri (350 mg L $\left.{ }^{-1}\right)$, E. coli $\left(90 \mathrm{mg} \mathrm{L}^{-1}\right)$, A. woodii $\left(70 \mathrm{mg} \mathrm{L}^{-1}\right), D$. vulgaris (65 $\mathrm{mg} \mathrm{L}^{-1}$ ) e $M$. formicicum $\left(90 \mathrm{mg} \mathrm{L}^{-1}\right.$ ), aproximadamente $70 \%$ do $\mathrm{CH} 4$ gerado ocorreu através da via do acetato.

A Tabela 5.4 mostra um balanço de massa calculado para os reatores em batelada para confirmar se os dados experimentais foram razoáveis. Os resultados do balanço apresentado nesta tabela demonstraram que houve poucos equivalentes faltando para os frascos contendo esgoto sanitário e vinhaça.

Conforme era esperado, os frascos contendo glicerol e água residuária de parboilização de arroz apresentaram considerável falta de equivalência, que ficou em torno de 21,50 e 24,10\%, respectivamente. É provável que esse déficit tenha sido originado na fase acidogênica do experimento, conforme demonstrado na Tabela 5.4

Os frascos contendo sacarose também apresentaram falta de equivalência, atingindo $19,7 \%$. Sugere-se que a geração de 2,3-Bu $(\mathrm{OH})_{2}$ (Lo et al. 2008) pelos microrganismos Klebsiella sp seja a causa do fechamento precário do balanço de DQO. Fernandes et al. (2010) e Peixoto et al. (2011) também sustentaram a mesma hipótese, uma vez que Klebsiella sp. foi encontrada em seus reatores e os métodos analíticos empregados não foram capazes de detectar a produção de 2,3-Bu $(\mathrm{OH})_{2}$. 
Tabela 5.4 - Balanço de massa (em termos de DQO) para os resultados obtidos na etapa metanogênica dos substratos avaliados.

\begin{tabular}{|c|c|c|c|c|c|c|c|c|c|c|c|c|c|c|c|c|c|c|}
\hline Substrato & $\begin{array}{l}\text { DQO } \\
\text { a } \\
\text { carb } \\
\text { (mg } \\
\text { DQO) }\end{array}$ & $\begin{array}{l}\text { DQO } \\
\mathrm{b} \\
\mathrm{H} 2 \\
(\mathrm{mg} \\
\mathrm{DQO})\end{array}$ & Hci & HМа & $\mathrm{HSu}$ & Hla & HFo & HAc & $\begin{array}{l}\mathrm{DQO}_{\text {pms }}{ }^{\mathrm{c}} \\
\text { (mg DQO } \\
\mathrm{HPr}\end{array}$ & Isob & $\mathrm{Hbu}$ & Isov & $\mathrm{HVa}$ & $\mathrm{HCa}$ & $\mathrm{EtOH}$ & $\begin{array}{l}\text { DQO } \\
\text { soma } \\
\text { (mg } \\
\text { DQO) }\end{array}$ & $\begin{array}{l}\mathrm{DQO} \\
\text { e } \\
\text { total } \\
\text { (mg } \\
\text { DQO) }\end{array}$ & $\begin{array}{l}\text { Equivalência }{ }^{\mathrm{f}} \\
(\%)\end{array}$ \\
\hline Esgoto & 3.1 & 8.3 & 7.7 & 3.5 & 7.3 & 19.3 & 0 & 14.7 & 14.7 & 21.1 & 21.2 & 25.9 & 21,7 & 0 & 0 & 152.3 & 181.5 & 16.0 \\
\hline Glicerol & 6.2 & 22.1 & 7.4 & 2.9 & 7.4 & 16.9 & 1.5 & 3.7 & 9.2 & 29.2 & 23.4 & 29.6 & 32.9 & 0 & 0 & 154.2 & 189.3 & 21.5 \\
\hline A.R Arroz & 0.0 & 25.2 & 6.4 & 0 & 8.3 & 31.5 & 1.9 & 0 & 26.3 & 0 & 19.8 & 25.3 & 21.9 & 0 & 0 & 116.4 & 153.5 & 24.1 \\
\hline Vinhaça & 10.8 & 17.0 & 3.2 & 5.0 & 7.4 & 10.6 & 1.3 & 9.4 & 13.9 & 20.3 & 0 & 26.1 & 13.0 & 0 & 5.0 & 109.6 & 129.7 & 15.4 \\
\hline Sacarose & 0 & 16.3 & 7.6 & 4.5 & 6.5 & 16.1 & 1.5 & 10.7 & 14.1 & 27.9 & 23.5 & 28.1 & 26.4 & 0 & 0 & 151.1 & 188.3 & 19.7 \\
\hline
\end{tabular}

aDQO ${ }_{\text {carb : }}$ DQO dos carboidratos residuais.

${ }^{\mathrm{b}} \mathrm{DQO}_{\mathrm{CH} 4}$ : $\mathrm{mg} \mathrm{DQO}$ do $\mathrm{CH}_{4}$ produzido, calculado como mol $\mathrm{CH}_{4}$ x $32 \mathrm{~g} \mathrm{DQO} \mathrm{mol} \mathrm{CH}{ }_{4}^{-1}$ x $1000 \mathrm{mg} \mathrm{g}^{-1}$

${ }^{\mathrm{C}} \mathrm{DQO}_{\mathrm{pms}}$ : DQO dos produtos metabólicos solúveis (PMS).

${ }^{\mathrm{d}} \mathrm{DQO}_{\mathrm{soma}}-\mathrm{DQO}_{\mathrm{CH} 4}$ : A soma de DQO dos carboidratos residuais e a DQO dos (PMS) - DQO envolvida na produção de metano.

${ }^{\mathrm{e}} \mathrm{DQO}_{\text {total }}$ : DQO medida no reator.

${ }^{\mathrm{f}}$ Calculado por $\left[\left(1-\left(\mathrm{DQO}_{\text {soma }}\right) /\left(\mathrm{DQO}_{\text {total }}\right)\right) \times 100 \%\right]$. 


\section{4 - Etapa 4 - Ensaios em batelada para a determinação da diluição de vinhaça em esgoto sanitário}

Nesta etapa a hipótese testada foi a de suplementação do esgoto sanitário com vinhaça, que foi o resíduo que mostrou o melhor desempenho na produção de hidrogênio e metano, conforme verificado na Etapa 3 deste capítulo. Por esse motivo, testes variando cinco diluições de vinhaça no esgoto sanitário foram realizados a fim de determinar o impacto de cada diluição sobre a produção de hidrogênio. As mesmas faixas de diluição de vinhaça também foram testadas com água deionizada, como forma de obter reatores controle.

Aos dez frascos do ensaio não foi adicionado meio contendo macro ou micronutrientes, pois a caracterização da vinhaça bruta apresentada na Tabela 5.5 mostra que este resíduo possuía concentrações suficientes destes elementos.

A caracterização da vinhaça utilizada neste trabalho foi feita no Laboratório de Saneamento do SHS-EESC-USP por seus respectivos técnicos. A amostra estava congelada em freezer de $500 \mathrm{~L}$ à $-4{ }^{\circ} \mathrm{C}$ juntamente com todo o restante do volume coletado na Usina Nova Era, que permanecia congelado até o momento de ser utilizado como substrato para os reatores. 
Tabela 5.5 - Caracterização da vinhaça utilizada nesta e nas Etapas 3, 5 e 6.

\begin{tabular}{llll}
\hline & \multicolumn{3}{c}{ Variáveis } \\
\hline DQO (bruta) & $20,731 \mathrm{~g} \mathrm{~L}^{-1}$ & Sólidos Totais & $18,17 \mathrm{~g} \mathrm{~L}^{-1}$ \\
DQO (filtrada) & $15,682 \mathrm{~g} \mathrm{~L}^{-1}$ & Sólidos Fixos & $3,72 \mathrm{~g} \mathrm{~L}^{-1}$ \\
pH & 3,81 & Sólidos Voláteis & $14,44 \mathrm{~g} \mathrm{~L}^{-1}$ \\
Sulfato & $371,33 \mathrm{mg} \mathrm{L}^{-1}$ & Ácido Cítrico & $2668,15 \mathrm{mg} \mathrm{L}^{-1}$ \\
Fosfato & $133 \mathrm{mg} \mathrm{L}^{-1}$ & Ácido Málico & $307,8 \mathrm{mg} \mathrm{L}^{-1}$ \\
Nitrogênio Total & $187,5 \mathrm{mg} \mathrm{L}^{-1}$ & Ácido Succínico & $1202,15 \mathrm{mg} \mathrm{L}^{-1}$ \\
Carboidratos Totais & $3 \mathrm{~g} \mathrm{~L}^{-1}$ & Ácido Lático & $3782,85 \mathrm{mg} \mathrm{L}^{-1}$ \\
Zn & $0,835 \mathrm{mg} \mathrm{L}^{-1}$ & Ácido Fórmico & $188,35 \mathrm{mg} \mathrm{L}^{-1}$ \\
$\mathrm{~Pb}$ & $0,105 \mathrm{mg} \mathrm{L}^{-1}$ & Ácido Acético & $1314,05 \mathrm{mg} \mathrm{L}^{-1}$ \\
$\mathrm{Cd}$ & $<0,0006 \mathrm{mg} \mathrm{L}^{-1}$ & Ácido Propiônico & $2016,5 \mathrm{mg} \mathrm{L}^{-1}$ \\
$\mathrm{Ni}$ & $0,0465 \mathrm{mg} \mathrm{L}^{-1}$ & Ácido Isobutírico & $748,8 \mathrm{mg} \mathrm{L}^{-1}$ \\
$\mathrm{Fe}$ & $136,8 \mathrm{mg} \mathrm{L}^{-1}$ & Ácido Butírico & $1026,55 \mathrm{mg} \mathrm{L}^{-1}$ \\
$\mathrm{Mn}$ & $3,35 \mathrm{mg} \mathrm{L}^{-1}$ & Ácido Isovalérico & $\mathrm{N}^{-1}$ \\
$\mathrm{Cu}$ & $0,3695 \mathrm{mg} \mathrm{L}^{-1}$ & Ácido Valérico & $559,85 \mathrm{mg} \mathrm{L}^{-1}$ \\
$\mathrm{Cr}$ & $0,0305 \mathrm{mg} \mathrm{L}^{-1}$ & Ácido Capróico & $548,1 \mathrm{mg} \mathrm{L}^{-1}$ \\
\hline
\end{tabular}

Nesta etapa, foi adicionada aos frascos aproximadamente a mesma concentração inicial do inóculo empregado na Etapa 3 deste capítulo, para que houvesse cerca de $300 \mathrm{mg} \mathrm{L}^{-1}$ SSV de biomassa acidogênica, desconsiderando os sólidos suspensos voláteis da vinhaça, pois a mesma não foi filtrada neste experimento, visando simular a condição operacional nos reatores contínuos das Etapas 5.5 e 5.6. Além disso, bicarbonato de sódio teve que ser utilizado para o controle do $\mathrm{pH}$.

Lay (2000) concluiu que o pH abaixo de 4,7 desfavorece a produção de hidrogênio por inibir a atividade da hidrogenase e de outras enzimas envolvidas no processo, por esse motivo foi necessário adicionar bicarbonato de sódio para o ajuste do $\mathrm{pH}$, uma vez que nos frascos controle, contendo a mistura de vinhaça em água deionizada o pH inicial foi de 4,13 e nos frascos contendo vinhaça e esgoto o $\mathrm{pH}$ foi de 4,52

A Tabela 5.6 mostra que o pH inicial foi satisfatoriamente corrigido para a 
faixa de 5,5 a 6,0 .

Tabela 5.6 - Aspectos operacionais do monitoramento dos reatores em batelada (Etapa 4).

\begin{tabular}{lcccccc}
\hline Amostra & $\begin{array}{c}\text { Pressão inicial } \\
\text { (mbar) }\end{array}$ & $\begin{array}{c}\text { Pressão final } \\
\text { (mbar) }\end{array}$ & $\begin{array}{c}\text { DQO bruta } \\
\left(\mathrm{mg} \mathrm{L}^{-1}\right)\end{array}$ & $\mathrm{pH}$ inicial & pH final & $\begin{array}{c}\text { Bicarbonato } \\
\text { de sódio } \\
\left(\mathrm{mg} \mathrm{L}^{-1}\right)\end{array}$ \\
\hline $2000 \mathrm{~A}+\mathrm{V}$ & 5,2 & 106,7 & 2030,45 & 5,67 & 5,5 & 40 \\
$3000 \mathrm{~A}+\mathrm{V}$ & 6 & 203 & 3194,65 & 5,63 & 5,32 & 40 \\
$4000 \mathrm{~A}+\mathrm{V}$ & 8,6 & 235 & 4090,55 & 5,51 & 5,25 & 60 \\
$5000 \mathrm{~A}+\mathrm{V}$ & 7,9 & 256,4 & 5225,05 & 5,49 & 5,15 & 80 \\
$10000 \mathrm{~A}+\mathrm{V}$ & 9,2 & $554(\mathrm{~F} . \mathrm{L})$ & 11117,8 & 5,71 & 5,1 & 120 \\
$2000 \mathrm{E}+\mathrm{V}$ & 9,6 & 115,3 & 2200,35 & 5,67 & 5,6 & 20 \\
$3000 \mathrm{E}+\mathrm{V}$ & 9,6 & 179,6 & 3391,9 & 5,51 & 5,49 & 20 \\
$4000 \mathrm{E}+\mathrm{V}$ & 9,6 & 208,4 & 4410,7 & 5,82 & 5,63 & 30 \\
$5000 \mathrm{E}+\mathrm{V}$ & 9,6 & 293,3 & 5425 & 5,74 & 5,52 & 60 \\
$10000 \mathrm{E}+\mathrm{V}$ & 9,6 & 613 (F.L) & 11045,4 & 5,67 & 5,3 & 100 \\
\hline
\end{tabular}

$\mathrm{A}+\mathrm{V}-$ Mistura de água deionizada mais vinhaça;

E+V- Mistura de esgoto sanitário mais vinhaça;

F.L - Fora do limite de detecção;

Na Tabela 5.6 é possível notar que foi necessário adicionar mais bicarbonato para correção de $\mathrm{pH}$ quando a vinhaça foi diluída em água deionizada. Provavelmente o ajuste de $\mathrm{pH}$ da vinhaça com esgoto necessitou de menos bicarbonato de sódio porque o esgoto sanitário apresentava alguma alcalinidade inicial, conforme mostrado na Etapa 1 deste capítulo.

A Figura 5.37 mostra que na diluição de vinhaça com água deionizada para a obtenção de DQO mais altas (a partir de $3000 \mathrm{mg} \mathrm{L}^{-1}$ ), a fase de adaptação dos microrganismos produtores de $\mathrm{H}_{2}$ foi maior e o rendimento na produção de hidrogênio foi menor, conforme mostrado na Figura 5.38. 


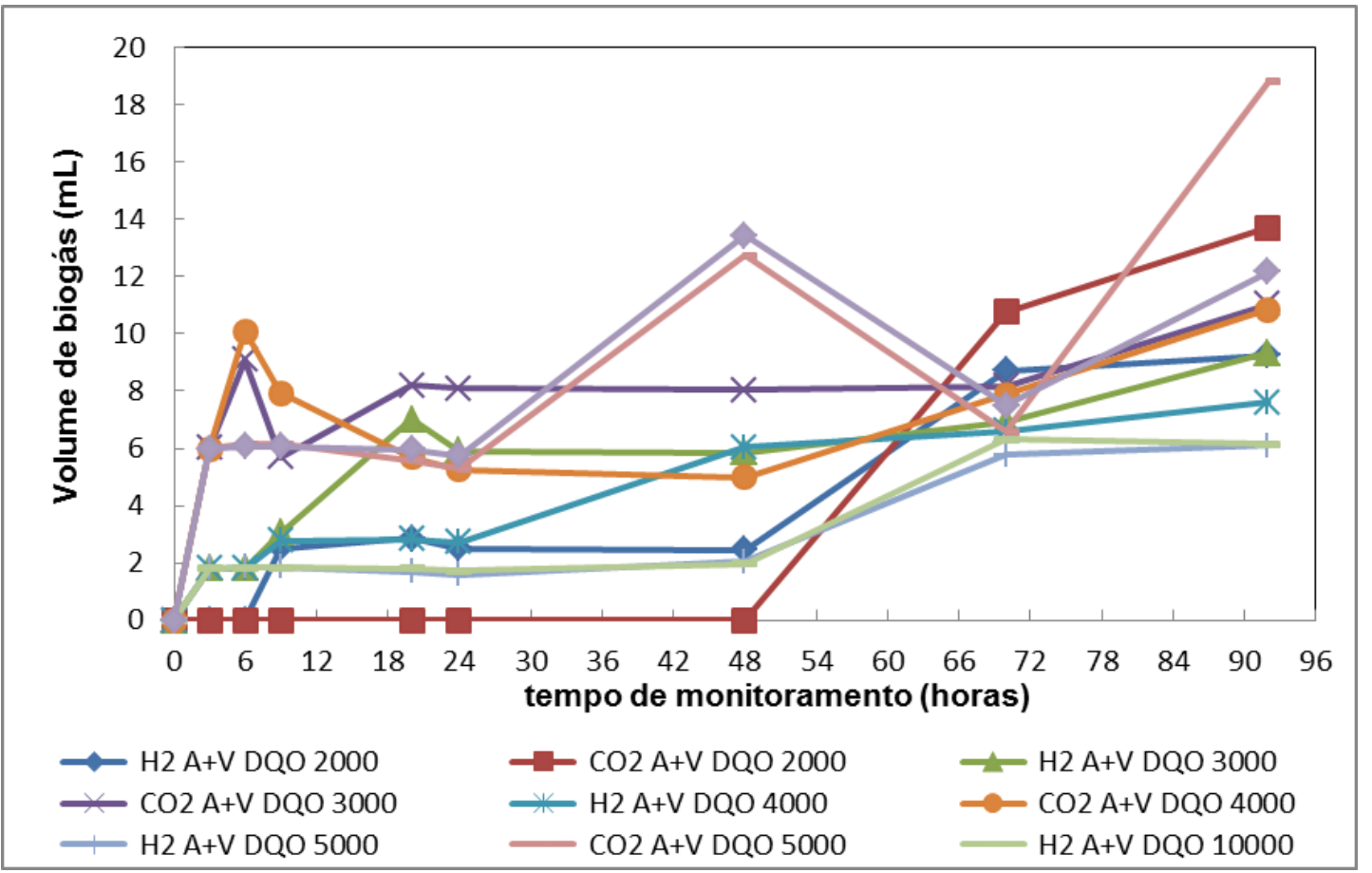

Figura 5.37 - Volume de $\mathrm{H}_{2}$ e $\mathrm{CO}_{2}$ produzidos em 5 diluições de vinhaça em água deionizada na Etapa 4.

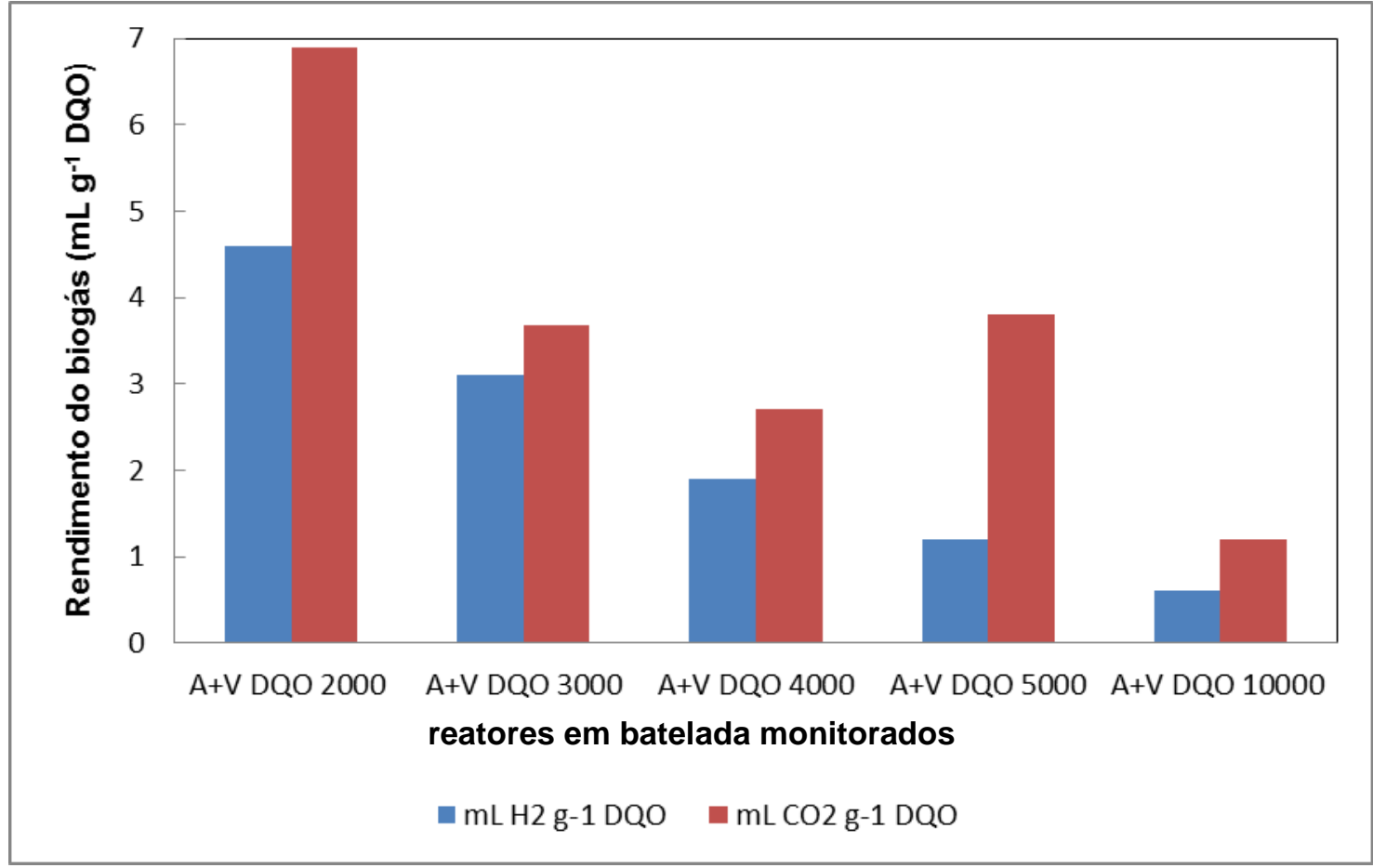

Figura 5.38 - Rendimento na produção de $\mathrm{H}_{2}$ e proporção de gases gerados para cada diluição de vinhaça em água deionizada na Etapa 4. 
Esses resultados indicam que pode ter havido um efeito negativo sobre a produção de hidrogênio em diluições de vinhaça em água deionizada que resultaram em DQO acima de $2000 \mathrm{mg} \mathrm{L}^{-1}$.

Wang et al. (2008) relataram que altas concentrações de ácido acético provocam efeito inibidor na produção de hidrogênio. Na vinhaça utilizada neste estudo a concentração de ácido acético de 1314,05 $\mathrm{mg} \mathrm{L}^{-1}$ provavelmente não atuou como elemento inibidor, tanto que no estudo de Wang et al. (2008) esse efeito foi observado para concentrações acima de $5000 \mathrm{mg} \mathrm{L}^{-1}$.

Zheng et al. (2005) também demonstraram que efeitos inibitórios de altas concentrações de ácido butírico sobre a biomassa anaeróbia de culturas mistas usadas para a produção de hidrogênio podem ocorrer, entretanto a concentração inicial reportada como inibitória foi cerca de seis vezes superior a de 1026,55 mg L ${ }^{-1}$ presente na composição da vinhaça deste trabalho (Tabela 5.5).

Logo, a hipótese mais plausível é a de que houve nestes frascos com concentrações de DQO acima de $2000 \mathrm{mg} \mathrm{L}^{-1}$ redução da produção de hidrogênio pela confluência de alguns fatores.

O primeiro poderia ser a perda do potencial de produção de hidrogênio pela biomassa inoculada, uma vez que foi demonstrado no estudo de Chang et al. (2002), em reatores anaeróbios para a produção de hidrogênio a partir de sacarose, que aumentos abruptos na concentração de substrato podem levar à queda na geração de hidrogênio.

No trabalho de Chang et al. (2002) foi mostrado que quando alimentação de seus reatores mudou de $20 \mathrm{~g} \mathrm{~L}^{-1}$ para $40 \mathrm{~g} \mathrm{~L}^{-1}$ de sacarose, houve uma alteração de produção de 0,62 $\mathrm{L} \mathrm{h}^{-1} \mathrm{H}_{2}$ para 0,42 $\mathrm{L} \mathrm{h}^{-1} \mathrm{H}_{2}$ com queda na fração de hidrogênio no 
biogás de $30 \%$ para $12,5 \%$, provavelmente porque a biomassa estava adaptada a concentrações menores de matéria orgânica.

O segundo fator foi considerado a partir da detecção de sulfeto de hidrogênio através de análise qualitativa do biogás por meio do medidor de gases no ambiente GX 2009. Esta análise com o medidor portátil foi feita porque os perfis de produção de hidrogênio e rendimento não estavam consistentes com o aumento na pressão medida dentro dos frascos com concentrações de DQO acima de $2000 \mathrm{mg} \mathrm{L}^{-1}$ nos frascos contendo vinhaça e água deionizada, conforme pôde se observar nos resultados apresentados na Tabela 5.6.

Ficou constatado, então, que nestes frascos o sulfeto de hidrogênio poderia ser o responsável pelo aumento da pressão detectada, uma vez que metano não foi detectado pelos métodos analíticos. A análise quantitativa do sulfeto de hidrogênio não foi possível, pois a produção do mesmo só foi detectada quando os frascos foram abertos e o cromatógrafo Gow-Mac Instrument Co® modelo 69, capaz de quantificar $\mathrm{H}_{2} \mathrm{~S}$ estava em manutenção.

A ocorrência de sulfeto de hidrogênio deveu-se à provável presença de microrganismos redutores de sulfato na própria vinhaça, pois a relação $\mathrm{DQO} / \mathrm{SO}_{4}{ }^{2-}$ neste resíduo esteve em torno de 42, ou seja, com excesso de matéria orgânica disponível para a redução do sulfato, uma vez que é necessário que a razão estequiométrica entre a DQO e o sulfato seja de 0,67 ou maior para a ocorrência do processo sem limitações (Lens et al., 1998).

Os resultados mostrados nas Figuras 5.39 e 5.40 mostram que nos frascos com a diluição da vinhaça pelo esgoto sanitário houve comportamento semelhante, porém mais acentuado em relação a perda de rendimento na produção de $\mathrm{H}_{2}$, o que 
pode ter ocorrido devido a provável existência de maior concentração de microrganismos redutores de sulfato no esgoto sanitário, uma vez que o mesmo dispunha de concentrações de sulfato de até $55 \mathrm{mg} \mathrm{L}^{-1}$ (Oliveira Netto, 2011).

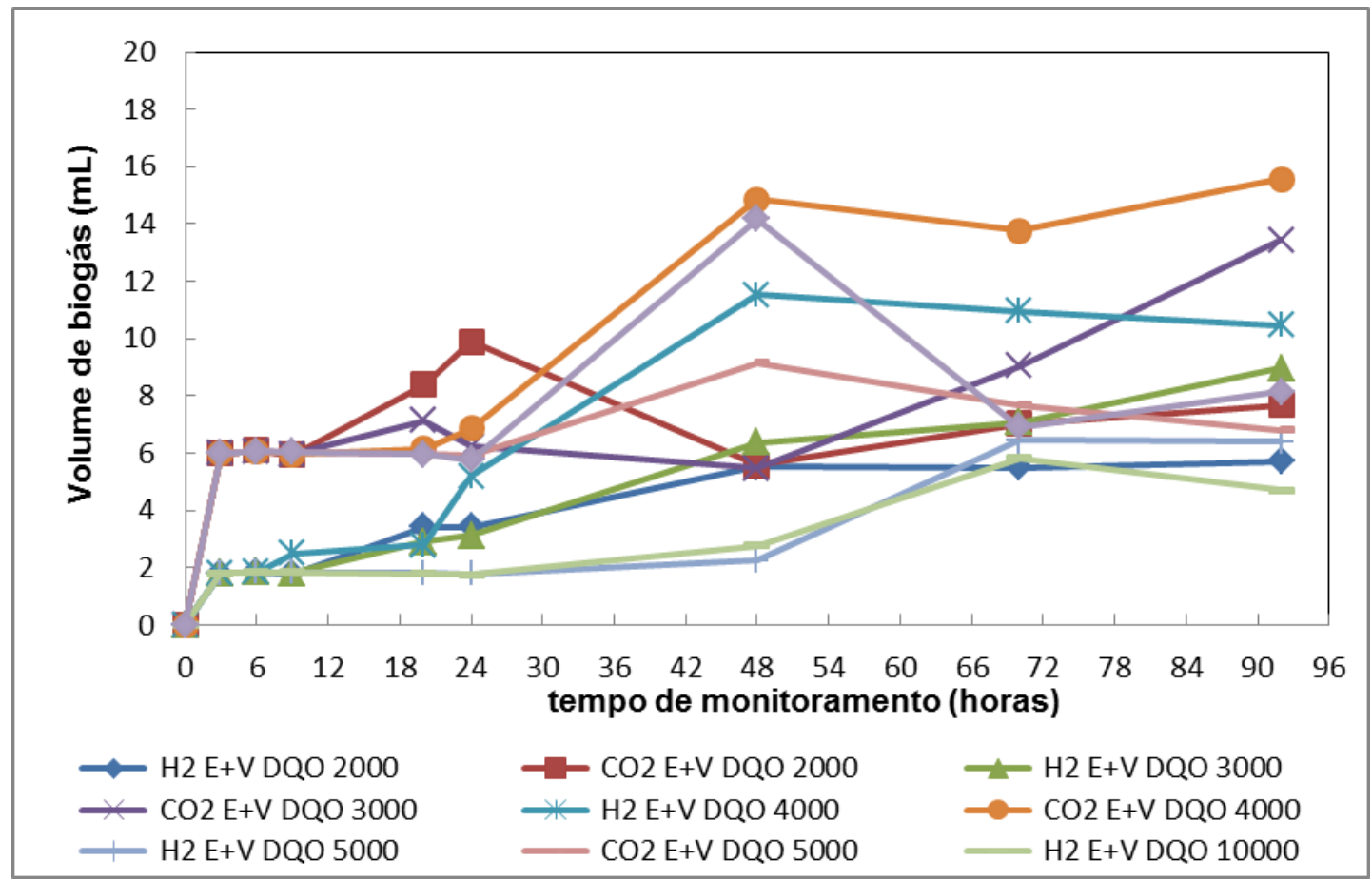

Figura 5.39 - Volume de $\mathrm{H}_{2}$ e $\mathrm{CO}_{2}$ produzidos em 5 diluições de vinhaça em esgoto sanitário na Etapa 4. 


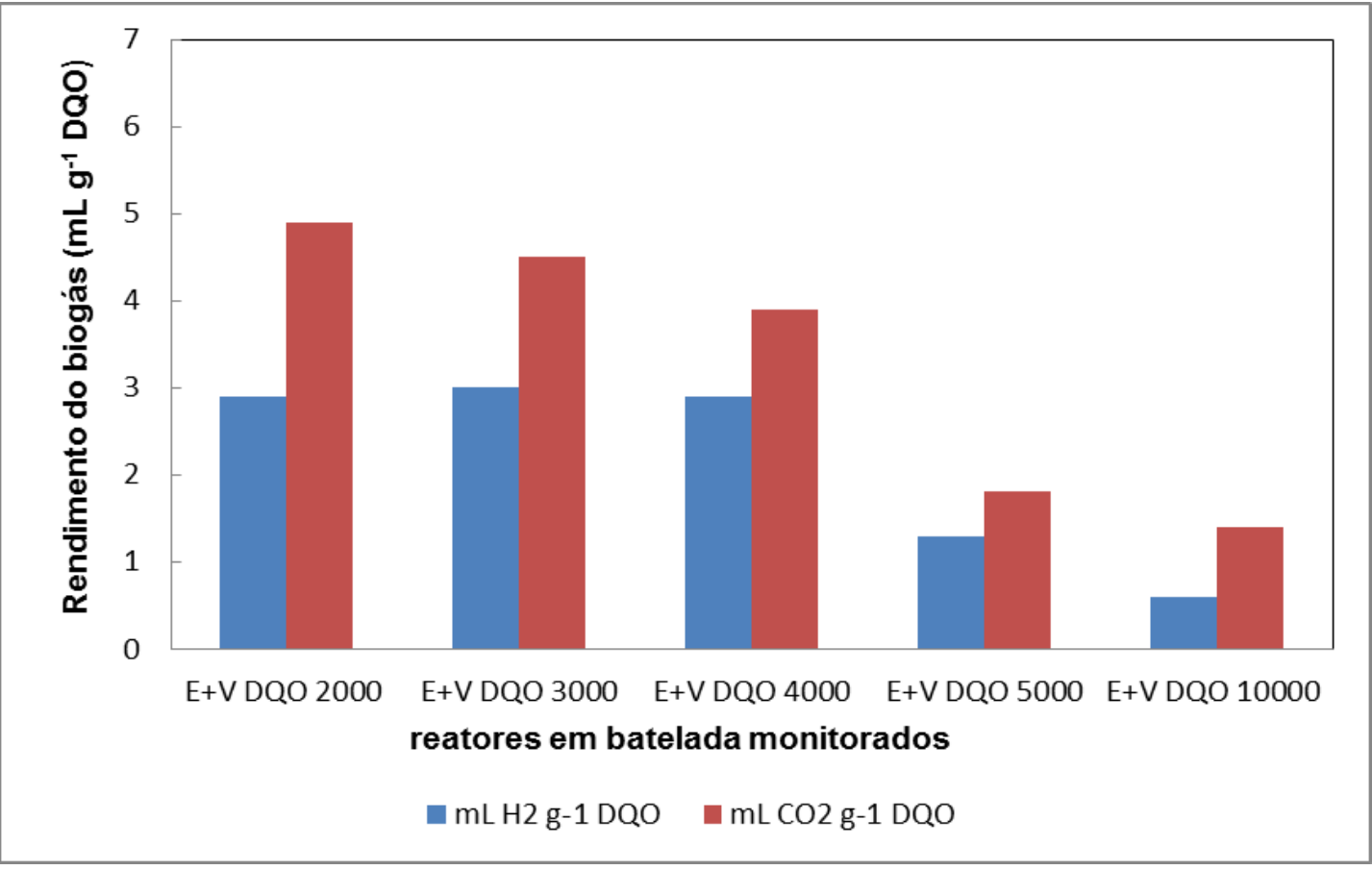

Figura 5.40 - Rendimento na produção de $\mathrm{H}_{2}$ e proporção de gases gerados para cada diluição de vinhaça em esgoto sanitário na Etapa 4.

Dessa forma, a diluição de vinhaça no esgoto sanitário que apresentou os melhores resultados foi a que resultou em $4000 \mathrm{mg} \mathrm{L}^{-1}$ DQO, produzindo nos reatores em batelada em torno de $10 \mathrm{~mL}$ de $\mathrm{H}_{2}$, com rendimento de $3 \mathrm{~mL} \mathrm{H}_{2} \mathrm{~g}^{-1}$ DQO.

\section{5 - Etapa 5 - Avaliação da influência de diferentes materiais suporte sobre a} produção de hidrogênio em reatores anaeróbios de leito fixo estruturado e fluxo ascendente

Nesta etapa, a hipótese testada foi de que as características dos materiais 
suporte poderiam contribuir para selecionar, por meio de adesão, bactérias produtoras de hidrogênio a partir da mistura de esgoto sanitário e vinhaça. Usou-se a configuração de reator tipo “B”, apresentada na seção 4.1.1 no capítulo de Material e Métodos, como forma de evitar a colmatação do leito, observada nas etapas 1 e 2 deste Capítulo.

A configuração de leito tipo $\mathrm{B}$, ou seja, com os suportes estruturados em coluna e intercalados, foi avaliada juntamente com a configuração de leito tipo A (controle), o que resultou nos comportamentos hidrodinâmicos mostrados nas curvas C apresentadas na Figura 5.41.

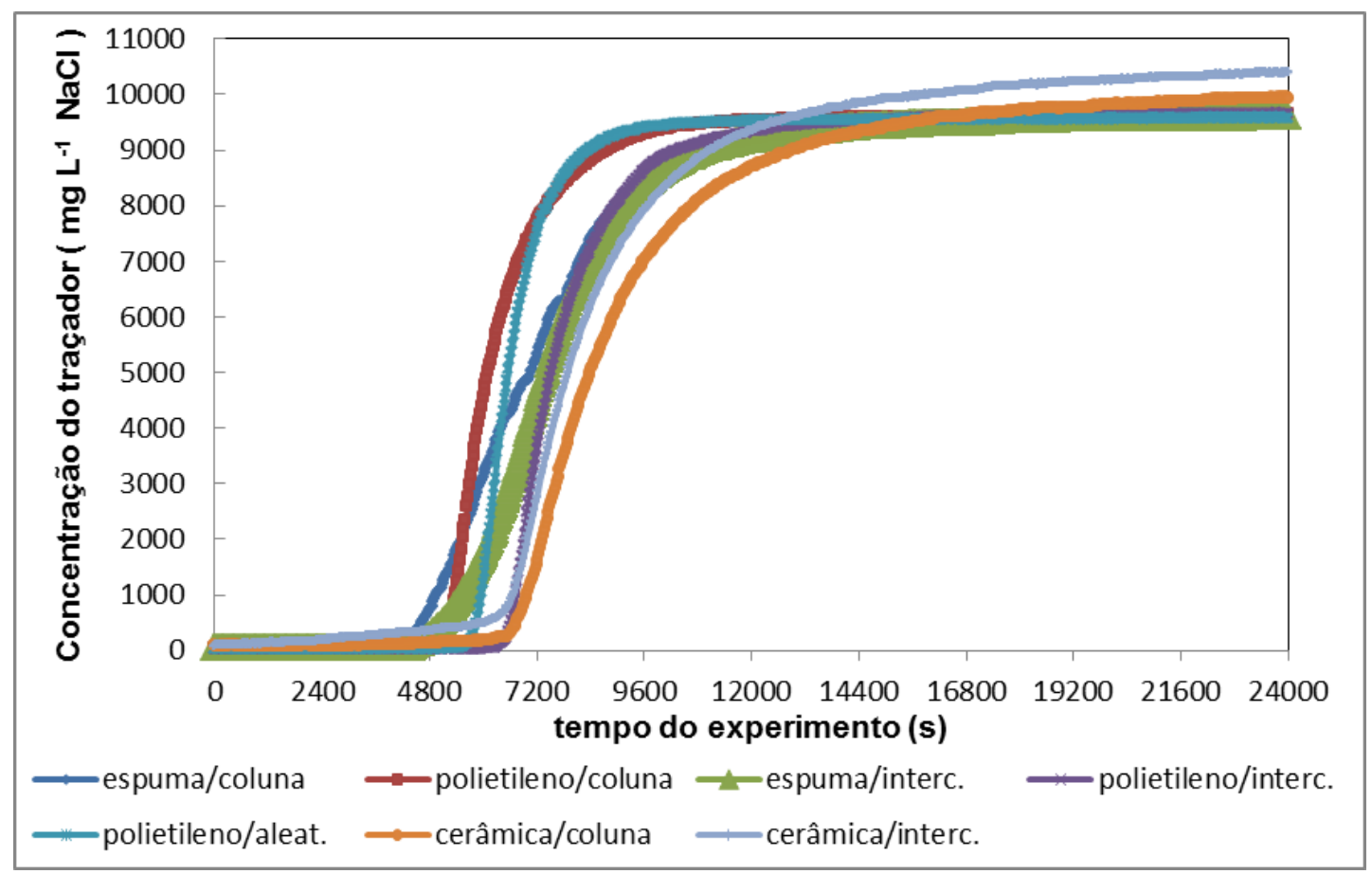

Figura 5.41 - Curvas C para cada material suporte submetido a diferentes configurações de leito avaliados na Etapa 5.

Por meio das análises das curvas C, seguindo o protocolo descrito na Etapa 4.6 do Capítulo 4, foram obtidos os resultados apresentados na Tabela 5.7. 
Tabela 5.7 - Características do escoamento com diferentes materiais suporte e configurações de leito avaliados na Etapa 5.

\begin{tabular}{lclccc}
\hline $\begin{array}{l}\text { Material } \\
\text { suporte }\end{array}$ & Tipo de leito & $\begin{array}{l}\text { Arranjo do } \\
\text { leito }\end{array}$ & $\begin{array}{c}\text { TDH } \\
\text { médio (h) }\end{array}$ & $\begin{array}{c}\mathrm{N} \\
\text { (n⿳⺈ } \\
\text { CSTR em } \\
\text { série) }\end{array}$ & $\begin{array}{c}\text { D/uL } \\
\text { (número de } \\
\text { dispersão) }\end{array}$ \\
\hline polietileno & empacotado & empacotado & 1,84 & 74 & 0,007 \\
polietileno & estruturado & coluna & 1,73 & 35 & 0,014 \\
polietileno & estruturado & intercalado & 2,12 & 46 & 0,011 \\
espuma & estruturado & coluna & 1,93 & 11 & 0,046 \\
espuma & estruturado & intercalado & 2,05 & 18 & 0,029 \\
sílica & estruturado & coluna & 2,38 & 20 & 0,025 \\
sílica & estruturado & intercalado & 2,27 & 20 & 0,025 \\
\hline
\end{tabular}

Logo, de acordo com os resultados apresentados na Tabela 5.7, o arranjo de leito estruturado que apresentou características hidrodinâmicas mais semelhantes à do leito empacotado foi o de leito estruturado intercalado. Esse tipo de arranjo de leito, no geral, resultou em TDHs médios mais próximos do esperado, menor dispersão e maior número de reatores CSTR em série, o que significa maior similaridade com o comportamento hidrodinâmico do tipo pistão, verificado nos trabalhos de Peixoto (2008) e Rojas (2010).

Dessa forma, nos itens 5.5.1, 5.5.2 e 5.5.3, foi empregado o arranjo de leito estruturado intercalado aos reatores utilizados, cada qual com seu respectivo material suporte.

\subsection{1 - Produção de hidrogênio a partir de esgoto sanitário suplementado com vinhaça por reatores anaeróbios de fluxo ascendente com leito estruturado com suportes de polietileno}


Com base nos resultados da Etapa 2, na qual determinou-se a concentração crítica de carboidratos para a ocorrência da produção de hidrogênio, havia ficado estabelecido que concentrações de carboidratos abaixo de $0,9 \mathrm{~g} \mathrm{~L}^{-1}$ seriam impeditivas para a geração de hidrogênio nas condições empregadas. Entretanto, na Etapa 4, que visou determinar o volume de vinhaça adicionado no esgoto sanitário que favorecesse a produção de hidrogênio, chegou-se a diluição que resultou na faixa de DQO de $4 \mathrm{~g} \mathrm{~L}^{-1}$ (vinhaça mais esgoto sanitário), na qual a concentração de carboidratos foi de aproximadamente $0,64 \mathrm{~g} \mathrm{~L}^{-1}$, o que situaria o afluente aos reatores desta etapa atual numa faixa de concentração de carboidratos na qual não foi possível medir a produção de hidrogênio.

Devido a essa constatação decidiu-se aumentar o volume de vinhaça adicionado ao esgoto sanitário, mesmo sob a pena de obter baixos rendimentos, conforme observado para concentrações acima de $4 \mathrm{~g} \mathrm{~L}^{-1}$ DQO da mistura de vinhaça com esgoto sanitário.

Optou-se por usar como suplementação um volume de vinhaça suficiente para atingir a concentração de aproximadamente $10 \mathrm{~g} \mathrm{~L}^{-1}$ DQO no meio de alimentação, ou seja, metade da vazão afluente aos reatores foi constituída de vinhaça e outra metade de esgoto sanitário. Nessa diluição de 1:1, o meio de alimentação dos reatores, composto pela mistura de vinhaça e esgoto, foi capaz de fornecer cerca de $1,5 \mathrm{~g} \mathrm{~L}^{-1}$ de carboidratos aos reatores.

Por esse motivo, os reatores desta etapa foram operados com $10 \mathrm{~mL} \mathrm{~min}{ }^{-1}$ de corrente afluente de vinhaça e $10 \mathrm{~mL} \min ^{-1}$ de corrente afluente de esgoto

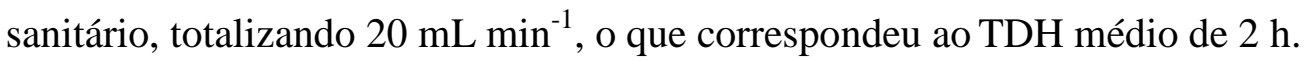

Conforme mostra a Figura 5.42, a partida do sistema após o procedimento de 
inoculação adotado nas Etapas 1 e 2, consistiu em alimentar o reator com a água residuária sintética usada por Rojas (2010) por 7 dias, na tentativa de assegurar que haveria adesão da biomassa produtora de hidrogênio nos suportes cilíndricos.

Nessa fase inicial ( $1^{\circ}$ ao $7^{\circ}$ dia de operação), o pH afluente médio foi de $6,0 \pm 0,5$, enquanto o efluente ficou em torno de $5,4 \pm 0,2$, que foram valores próximos aos obtidos por Peixoto (2008) e Rojas (2010).

A remoção de carboidratos atingiu a média de $67 \%$ nos primeiros 7 dias de operação, o que era esperado utilizando-se sacarose nas fase inicial de crescimento das bactérias produtoras de hidrogênio.

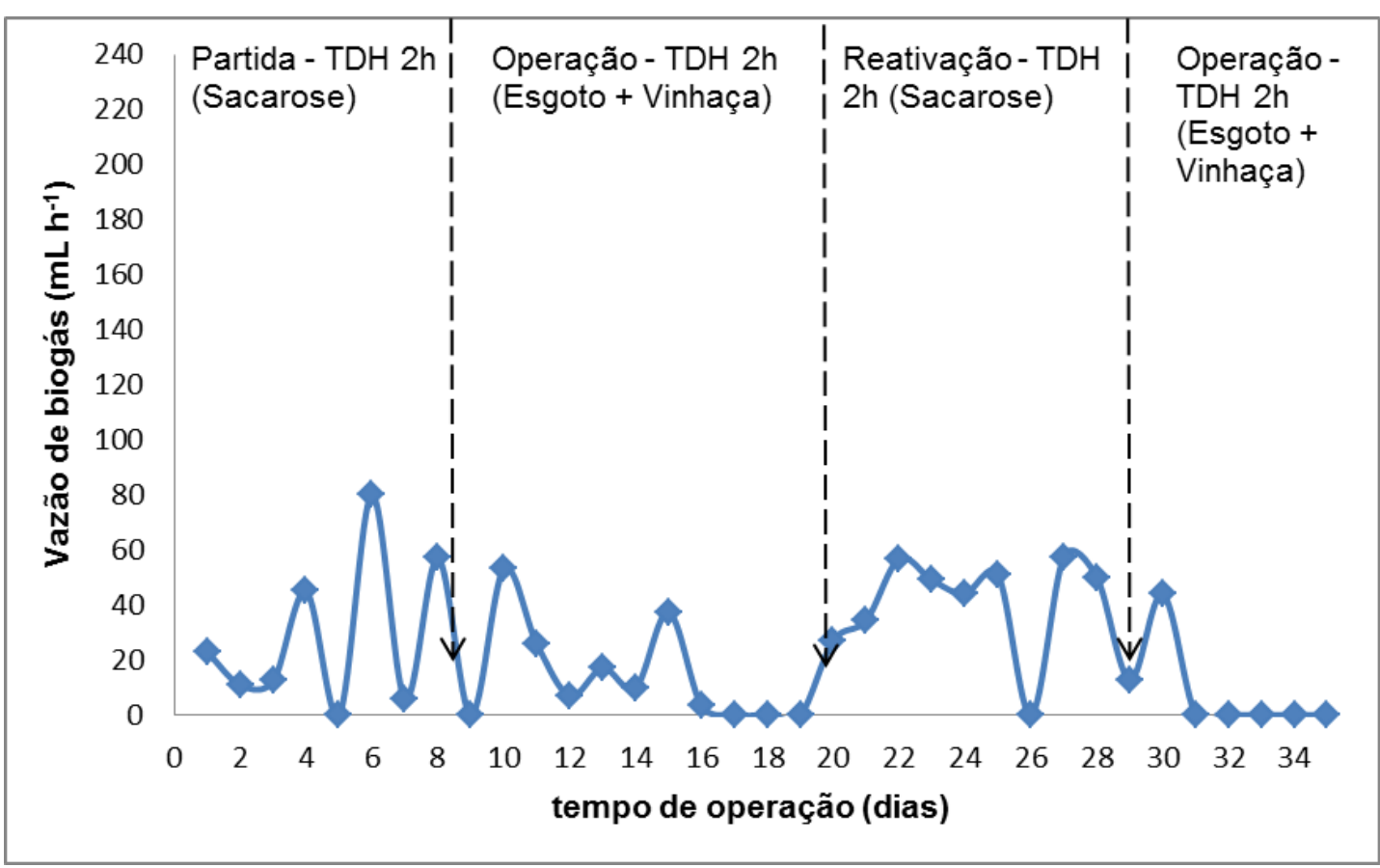

Figura 5.42 - Vazão de biogás no reator de polietileno com TDH de 2h (Etapa 5).

Do $9^{\circ}$ ao $19^{\circ}$ dia de operação, a alimentação foi mudada para a mistura de esgoto sanitário e vinhaça e o $\mathrm{pH}$ médio do afluente foi de $6,1 \pm 0,8$, enquanto o $\mathrm{pH}$

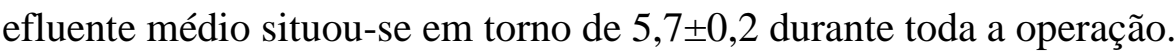

É importante ressaltar que a vinhaça tinha seu $\mathrm{pH}$ corrigido usando $2 \mathrm{~g} \mathrm{~L}^{-1}$ de 
bicarbonato de sódio, pois sem a adição do alcalinizante seu pH inicial era de 3,8.

Neste período, houve a queda na remoção de carboidratos para $35 \pm 10 \%$, e o declino e cessação da produção de biogás por 5 dias.

Na Figura 5.42, nota-se que na operação de partida do reator com o TDH de 2 h, sendo alimentado com o meio sintético, a produção de biogás mostrou-se oscilante, porém sem cessar. Logo que o reator passou a ser alimentado com vinhaça e esgoto sanitário, tanto a produção de biogás quando a remoção de carboidratos sofreram queda significativa.

O mesmo perfil de transição se delineou na composição do biogás coletado no headspace do reator, conforme mostra a Figura 5.43.

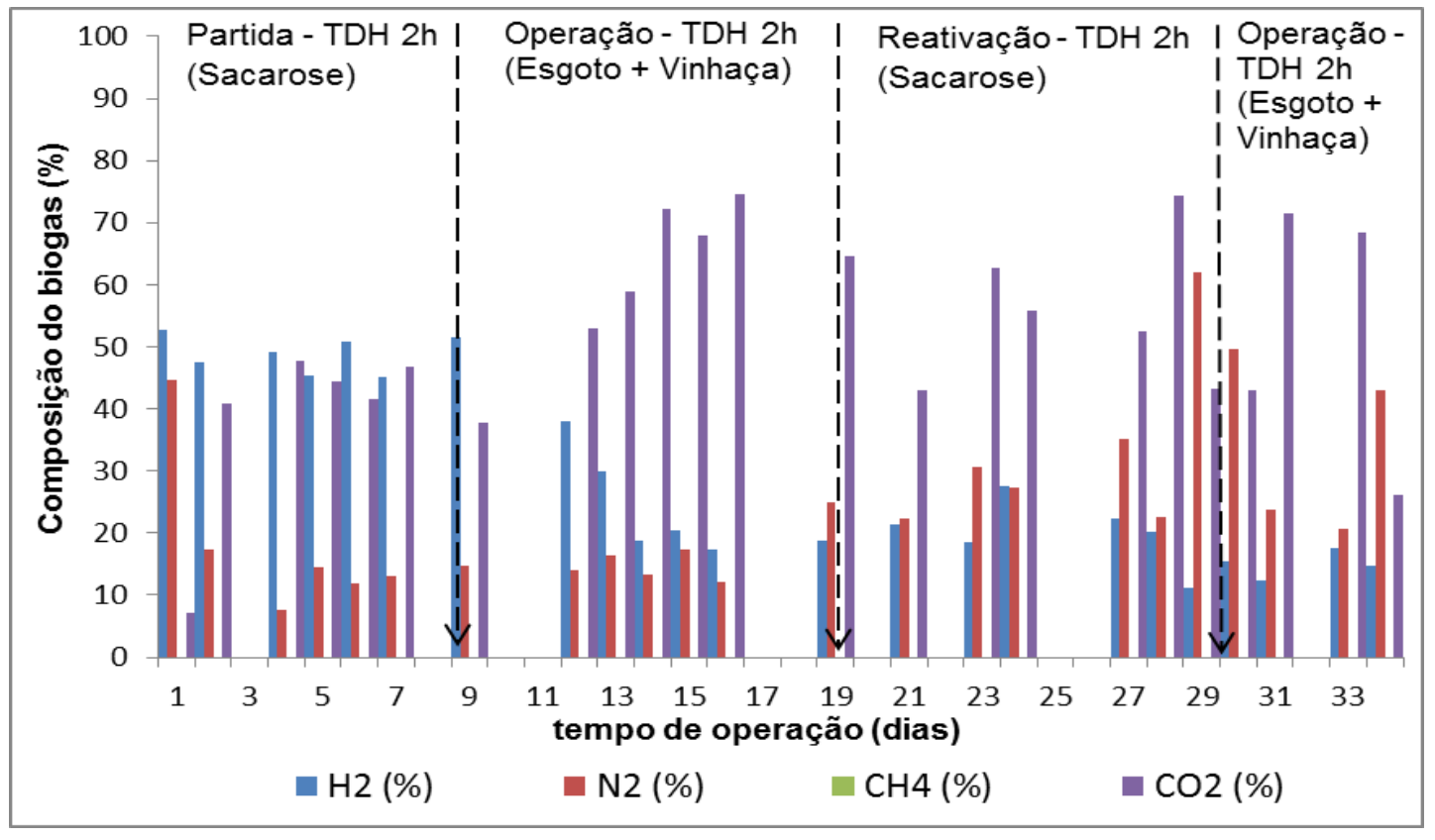

Figura 5.43 - Composição do biogás no reator no reator de polietileno com TDH de 2h (Etapa 5).

Devido a alteração significativa da composição do biogás, na qual a concentração de hidrogênio passou de 48,4 \% para 27,8 \%, decidiu-se incluir uma 
etapa de reativação do reator com duração de 7 dias, nos quais o sistema foi alimentado com o meio sintético usado por Rojas (2010), assim como nos primeiros 7 dias de operação.

Com esse procedimento notou-se uma reativação temporária da produção de hidrogênio, conforme pode ser visto na Figura 5.42, no período que compreende o $21^{\circ}$ e o $29^{\circ}$ dias de operação.

Após o reinício da alimentação com a mistura vinhaça/esgoto, no $30^{\circ}$ dia de operação, a produção de biogás cessou novamente e houve alteração na composição do mesmo, com redução da porcentagem de hidrogênio e aumento da concentração de dióxido de carbono e nitrogênio, sendo que este último aparecia provavelmente devido a entrada de ar dissolvido na corrente de alimentação do esgoto sanitário.

Com base na repetição do padrão anterior, decidiu-se mudar o TDH para 8 h baseando-se na hipótese que o TDH de 2 h não seria suficiente para reter biomassa produtora de hidrogênio em um reator que não fosse de leito empacotado.

De fato, a operação do reator com TDH de 8 h levou a não-cessação da produção de biogás, conforme mostra a Figura 5.44. Porém, a partir do $57^{\circ}$ dia de operação não foi mais detectado hidrogênio no biogás produzido pelo reator. A Figura 5.45 ilustra esse comportamento, bem como o início da detecção de metano no sistema. 


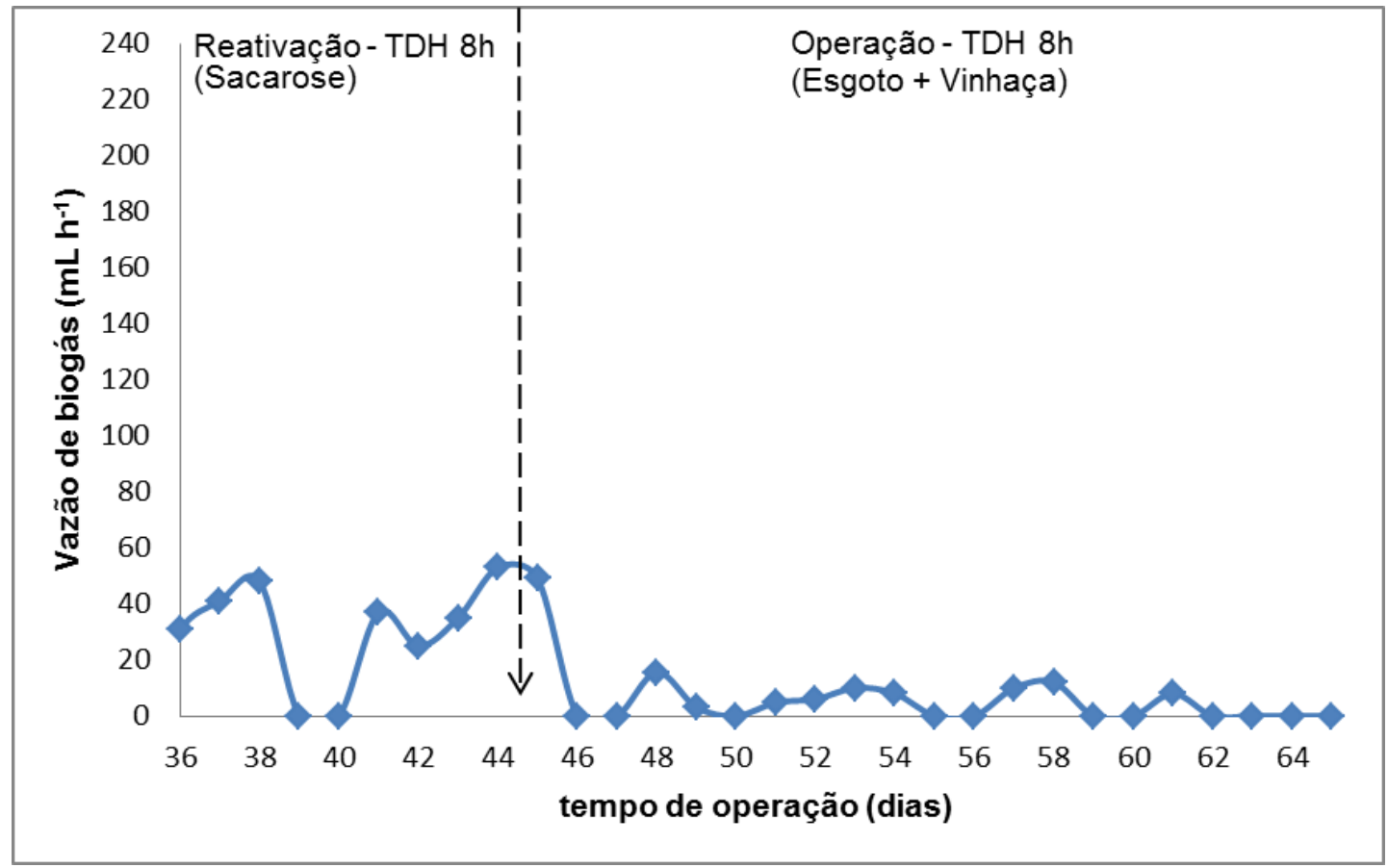

Figura 5.44 - Vazão de biogás no reator de polietileno com TDH de 8h (Etapa 5).

Posteriormente à detecção de metano, na semana final de operação do sistema, foi detectado sulfeto de hidrogênio com o medidor de gases para o ambiente GX 2009.

A Figura 5.45 mostra que a detecção de sulfeto foi feita depois do $60^{\circ}$ dia de operação. 


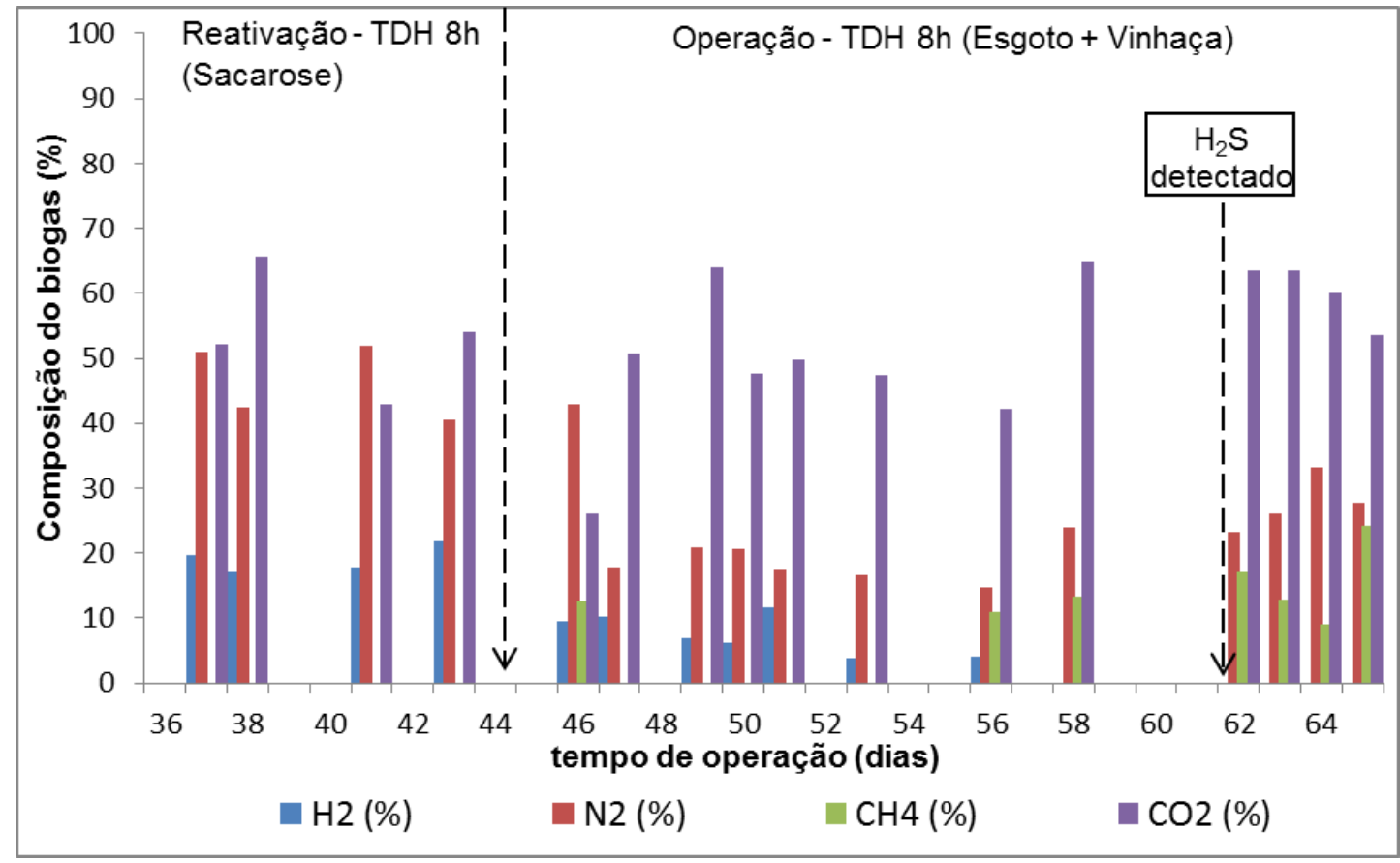

Figura 5.45 - Composição do biogás no reator de polietileno com TDH de 8h (Etapa 5).

É provável que tanto o TDH mais elevado quanto a própria composição da vinhaça tenham possibilitado o desenvolvimento de microrganismos consumidores de hidrogênio, tais como: arqueias metanogênicas e bactérias redutoras de sulfato, que constituem comunidades tipicamente encontradas nos esgotos sanitários.

Apesar do $\mathrm{pH}$ relativamente baixo do afluente, autores como Shin et al. (2004) demonstraram que metano pode ser produzido em meios com pH em torno de 5,8 .

Outro fator agravante em relação ao consumo de hidrogênio do sistema pode ter sido a relação DQO/sulfato da vinhaça, que na Etapa 4 foi calculada em 42, o que possivelmente contribuiu para o desenvolvimento das bactérias redutoras de sulfato devido às condições favoráveis para esse processo. 


\subsection{2 - Produção de hidrogênio a partir de esgoto sanitário suplementado com vinhaça em reatores anaeróbios de fluxo ascendente com leito estruturado com suportes de espuma de poliuretano}

O reator de leito estruturado com suportes cilíndricos de espuma de poliuretano foi operado em paralelo com o reator de leito estruturado com suportes de polietileno de baixa densidade. Por esse motivo esse reator seguiu exatamente os mesmos procedimentos de partida e reativação descritos para o reator de leito estruturado com cilindros de polietileno.

Na partida do sistema o $\mathrm{pH}$ afluente médio foi de $6,1 \pm 0,5$, enquanto o efluente ficou em torno de 5,6 $\pm 0,1$.

A remoção de carboidratos atingiu 72\% durante o procedimento de partida, porém mostrou queda de $17 \%$ quando a mistura vinhaça/esgoto foi usada como substrato. Houve queda também na produção de biogás conforme mostra a Figura 5.46, embora a produção de hidrogênio na partida do sistema tenha sido aproximadamente 2 vezes maior que a reportada no reator com suportes de polietileno de baixa densidade. Esse resultado com a espuma de poliuretano permitiu a formulação da hipótese de que a maior produção de biogás no TDH de 2 h estaria ligada a maior capacidade de retenção de microrganismos no reator. 


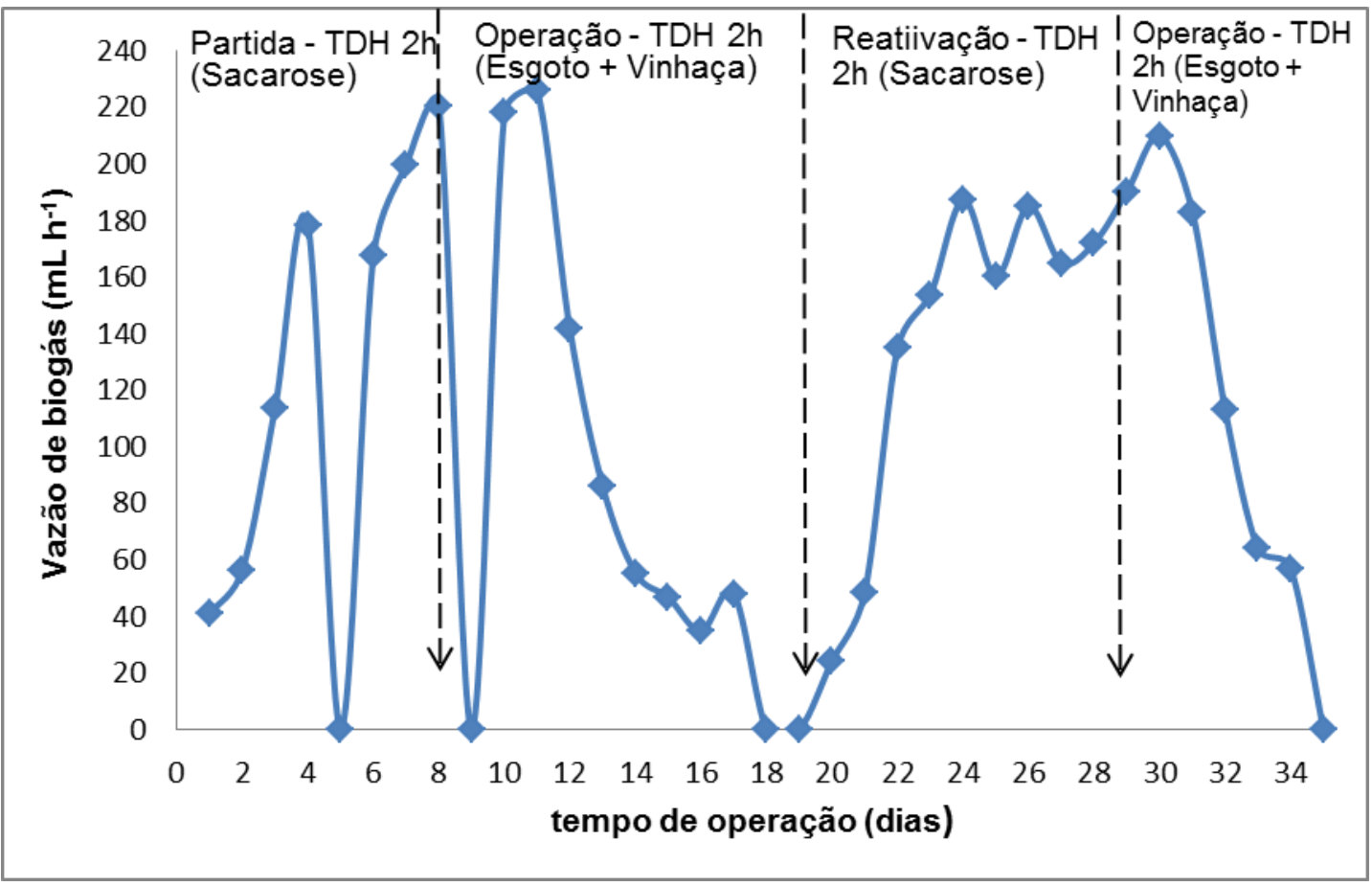

Figura 5.46 - Vazão de biogás no reator de espuma com TDH de 2h (Etapa 5).

Como na operação do reator com polietileno de baixa densidade, observou-se também alterações desfavoráveis na composição do biogás após o início da operação com esgoto sanitário e vinhaça como substrato, conforme pode ser observado na Figura 5.47.

A fração de hidrogênio no biogás decresceu até chegar a $18 \%$ no $20^{\circ}$ dia de operação. Neste mesmo período a vazão de biogás chegou a cessar por 2 dias.

Assim como no reator com suportes de polietileno, foi realizada uma etapa de reativação que consistiu em alimentar o reator com o meio usado no seu procedimento de inoculação por 7 dias. 


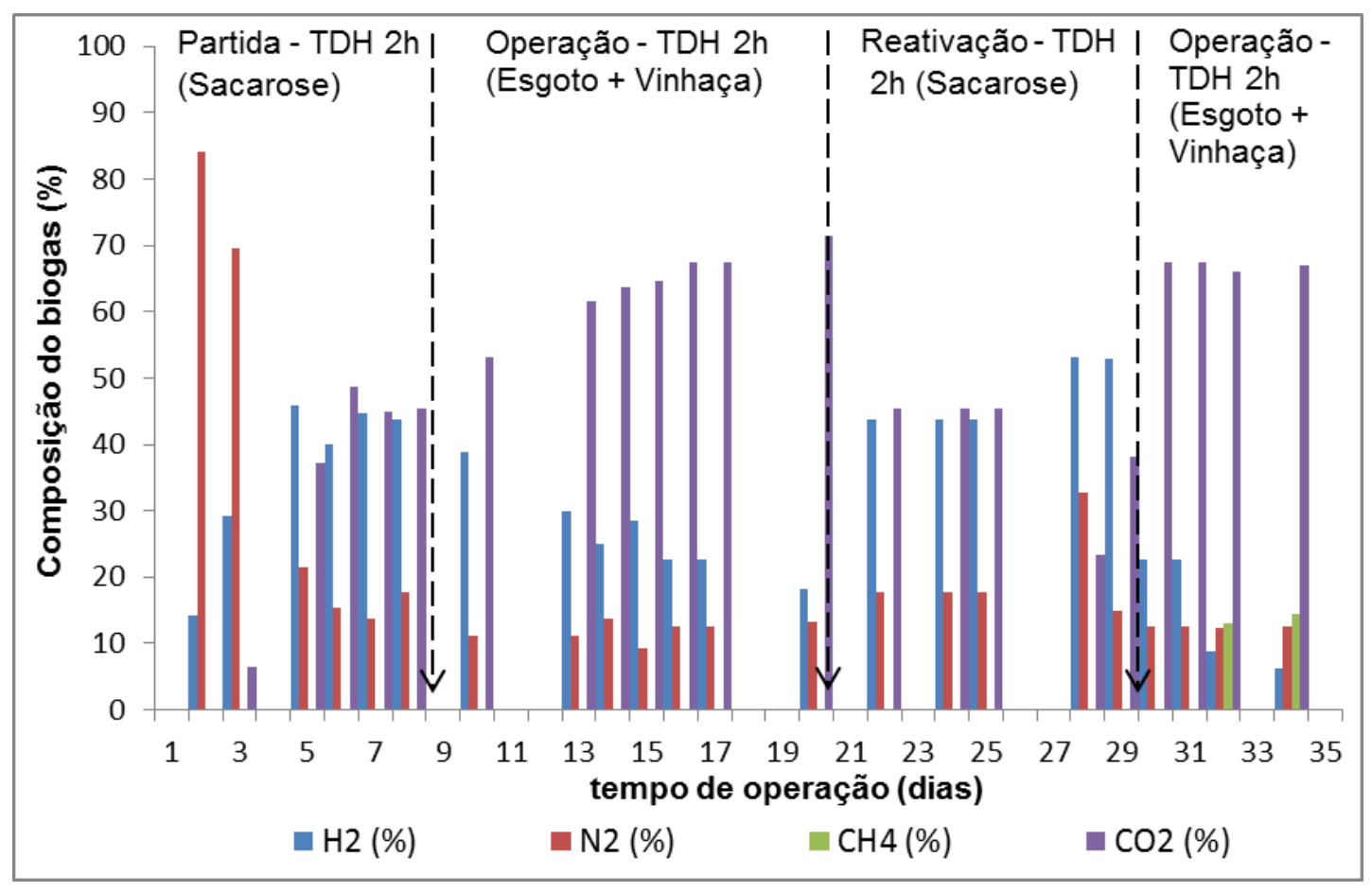

Figura 5.47 - Composição do biogás no reator de espuma com com TDH de 2h (Etapa 5).

Logo após a finalização do período de reativação, no $29^{\circ}$ dia de operação a vazão de biogás tornou a decrescer, assim como observado no reator com suportes de polietileno, porém foi detectada no biogás a presença de metano no $32^{\circ}$ e $34^{\circ}$ dias de operação, conforme se observa na Figura 5.47.

Seguindo o procedimento de reativação para a operação no TDH de 8h, alimentou-se novamente o reator com substrato sintético por 7 dias, assim como mostrado na Figura 5.48. 


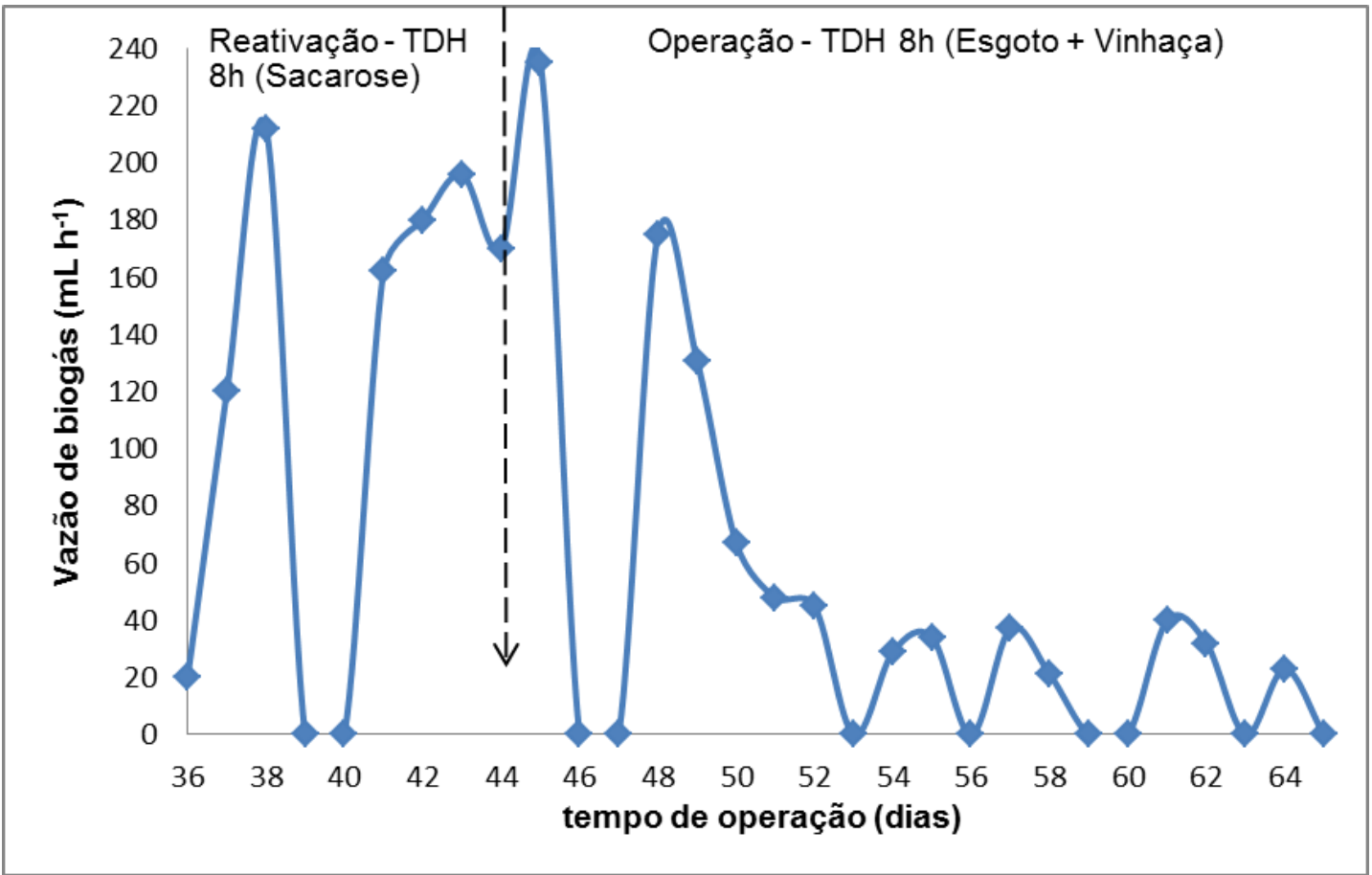

Figura 5.48 - Vazão de biogás no reator de espuma com TDH de 8h (Etapa 5).

Assim como reportado no reator com suportes de polietileno, o TDH de $8 \mathrm{~h}$ não levou a cessação da produção de biogás, porém neste reator com suportes cilíndricos de espuma de poliuretano, o gás hidrogênio não foi mais detectado a partir do $50^{\circ}$ dia de operação, conforme pode se observar na Figura 5.49.

Provavelmente este fato esteve ligado ao estabelecimento de microrganismos consumidores de hidrogênio, principalmente produtores de metano, pois esse gás foi detectado desde o final da etapa com TDH de 2 h e logo no início da etapa com TDH de 8 h. A Figura 5.49 também mostra que sulfeto de hidrogênio foi detectado bem antes neste reator, com aproximadamente duas semanas de antecedência em relação ao sistema operado com suportes de polietileno. É provável que o estabelecimento dessas comunidades esteja relacionado com as características do material suporte empregado no reator, como alta capacidade de retenção da biomassa, por exemplo, o 
que poderia ser conseqüência de sua elevada área superficial específica, que foi de 25,15 $\mathrm{m}^{2} \mathrm{~g}^{-1}$ de suporte, frente a 11,78 e 7,94 $\mathrm{m}^{2} \mathrm{~g}^{-1}$ obtidos com a cerâmica e o polietileno de baixa densidade.

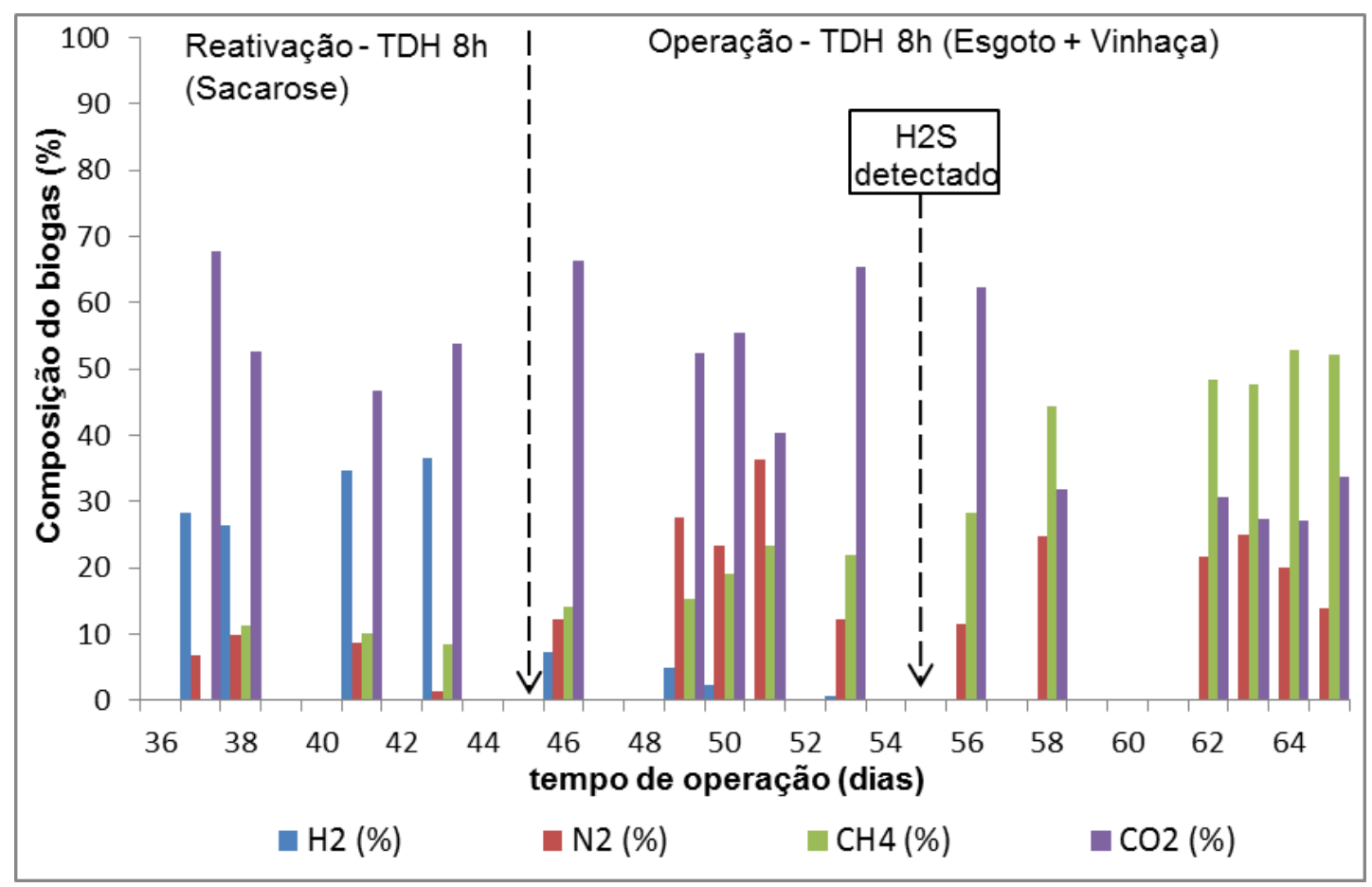

Figura 5.49 - Composição do biogás no reator de espuma com TDH de 8h (Etapa 5).

Devido a frequente ocorrência de metano mostrada nas Figuras 5.47 e 5.49, três suportes de espuma de poliuretano foram retirados do reator ao final da operação para verificar por meio de microscopia ótica a presença de alguma morfologia relacionada aos microrganismos produtores de metano.

As fotografias apresentada nas Figuras 5.50 e 5.51, feitas a partir da observação de amostras retiradas da superfície do material suporte podem corroborar a hipótese de que microrganismos relacionados com a produção de metano se desenvolveram no reator com suportes de espuma de poliuretano, mesmo com $\mathrm{pH}$ médio afluente de 5,8 $\pm 0,4$.

A fotografia da microscopia realizada ao final da operação mostra 
morfologias muito semelhantes ao gênero Methanisarcina (Chaban et al. 2006)

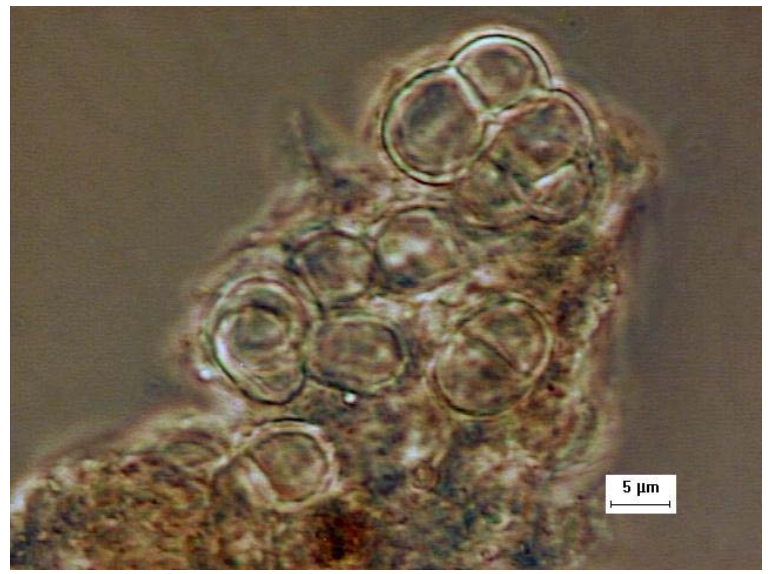

Figura 5.50 - Microscopia ótica da biomassa retirada do suporte de espuma de poliuretano (Etapa 5).

Como forma de reforçar a suspeita da ocorrência de microrganismos metanogênicos, a lâmina em questão foi submetida ao filtro ultravioleta e a amostra fluoresceu, conforme pode ser visto na Figura 5.51.

A fluorescência é geralmente típica de alguns representantes do Domínio Archaea, e é resultante da presença da coenzima $F_{420}$ (Madigan et al., 1997).

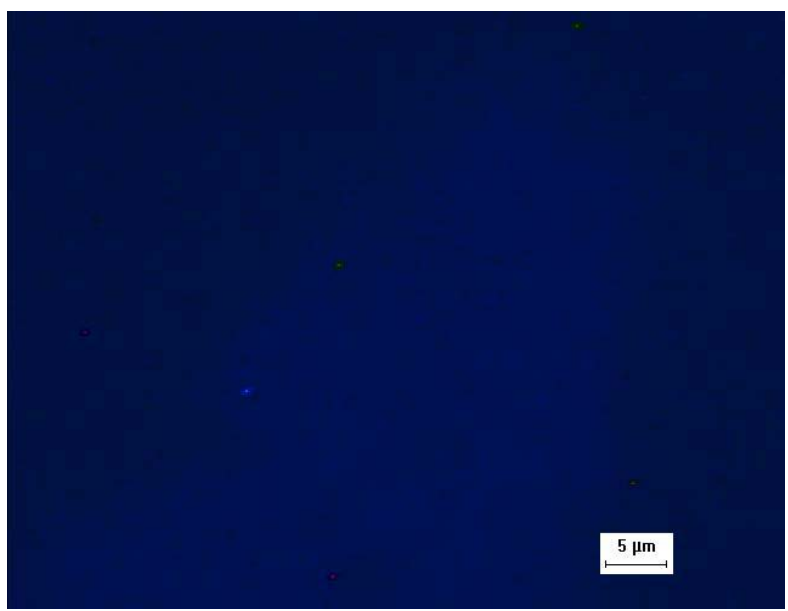

Figura 5.51 - Microscopia ótica com fluorescência da biomassa retirada do suporte de espuma de poliuretano (Etapa 5). 


\subsection{3 - Produção de hidrogênio a partir de esgoto sanitário suplementado com} vinhaça por reatores anaeróbios de fluxo ascendente com leito estruturado com suportes de cerâmica

O reator anaeróbio de leito estruturado com suportes de cerâmica foi operado em fase posterior aos reatores com suportes de polietileno e espuma de poliuretano, porém foi seguido exatamente o mesmo procedimento experimental aplicado aos demais reatores. A Figura 5.52 mostra que a partida e a operação por 35 dias com TDH de $2 \mathrm{~h}$ apresentou comportamento semelhante ao observado nos reatores com polietileno e espuma.

A produção de biogás foi instável com o TDH de 2 h, conforme mostra a Figura 5.52, o que foi uma característica comum aos demais sistemas operados com este TDH.

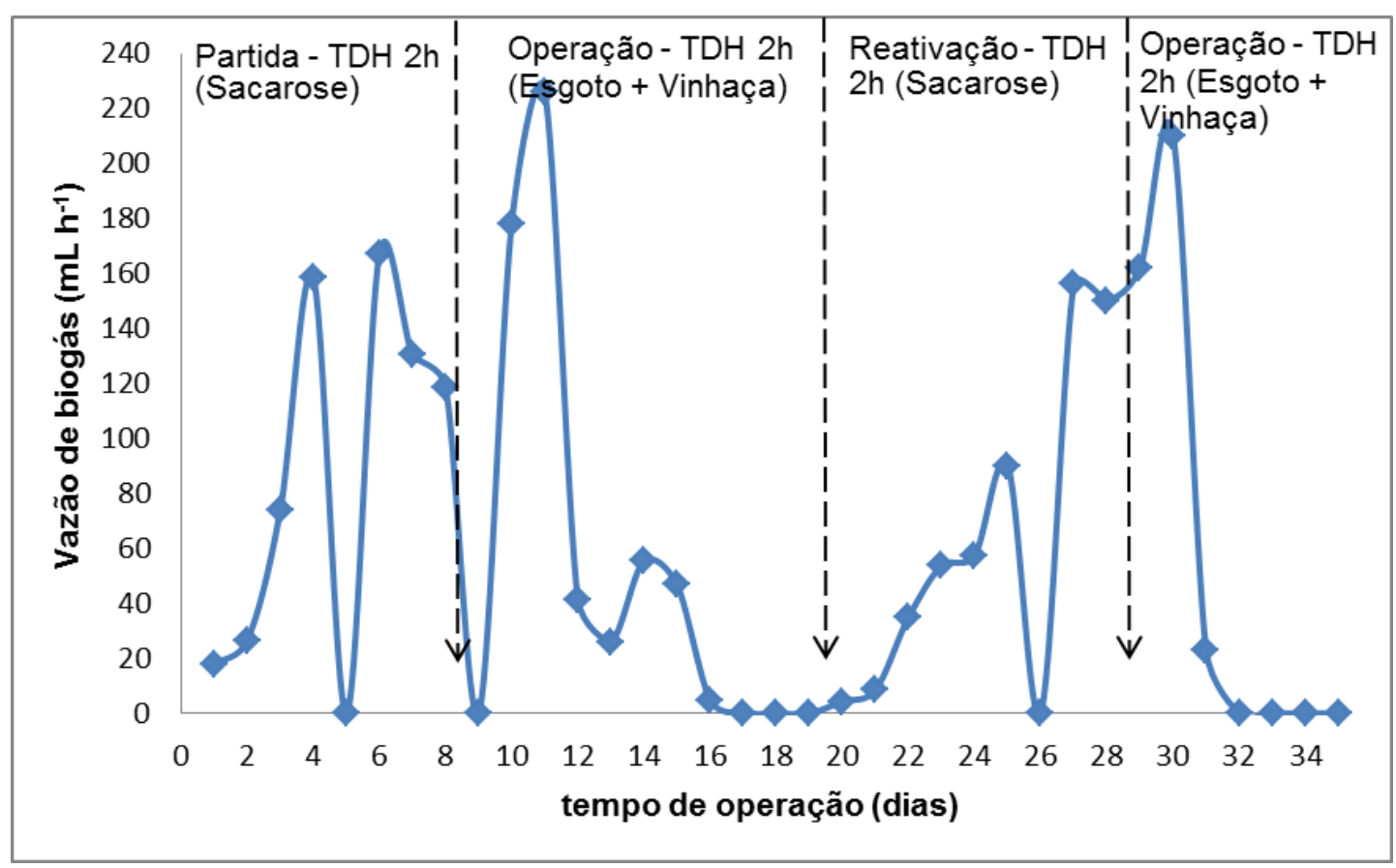

Figura 5.52 - Vazão de biogás no reator de cerâmica com TDH de 2h (Etapa 5). 
Nota-se na Figura 5.53 que não foi detectado metano no TDH de 2 h deste reator, mas ocorreram significativos decréscimos na fração de hidrogênio do biogás quando se operou o reator com as correntes de esgoto sanitário e vinhaça.

A concentração média de hidrogênio no biogás durante a partida foi de $55,8 \%$, enquanto que no período do $10^{\circ}$ ao $20^{\circ}$ dia de operação essa concentração caiu para 28,7\%. Fenômeno semelhante foi observado nos demais reatores, sem exceção, e provavelmente esteve relacionado ao não estabelecimento de uma população produtora de hidrogênio.

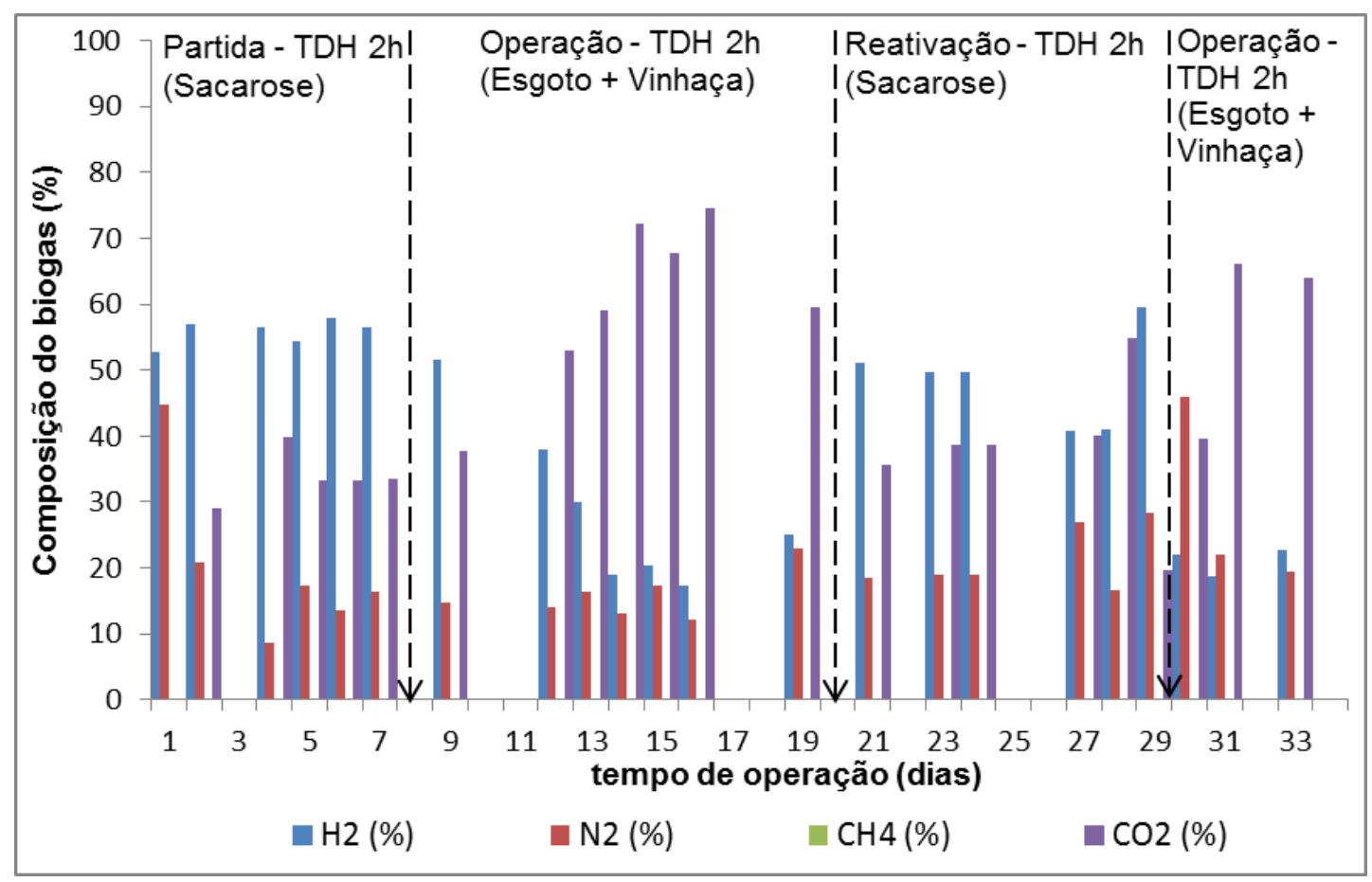

Figura 5.53 - Composição do biogás no reator de cerâmica com TDH de 2h (Etapa $5)$.

No tocante à produção volumétrica de biogás no TDH de 8 h com esgoto e vinhaça como afluentes, o suporte cerâmico apresentou em média 16,2 $\mathrm{mL} \mathrm{h}^{-1}$, o que 
o situou entre o polietileno, com média de $4,1 \mathrm{~mL} \mathrm{~h}^{-1}$ e a espuma de poliuretano, com média de 35,8 mL h ${ }^{-1}$. Contudo, o suporte cerâmico apresentou a vantagem de não favorecer prontamente, como a espuma de poliuretano, a adesão de microrganismos consumidores de hidrogênio, o que se refletiu na porcentagem média de hidrogênio no biogás no TDH de 8 h, que foi de 7,1\% para a cerâmica e de 1,4\% para a espuma de poliuretano. Já o reator com suporte de polietileno apresentou média de 6,6\%, que foi um resultado muito próximo ao obtido no reator com suportes de cerâmica.

A Figura 5.54 mostra que a reativação do reator com o TDH de 8h foi eficiente, assim como observado nos reatores com suporte de polietileno e de espuma de poliuretano.

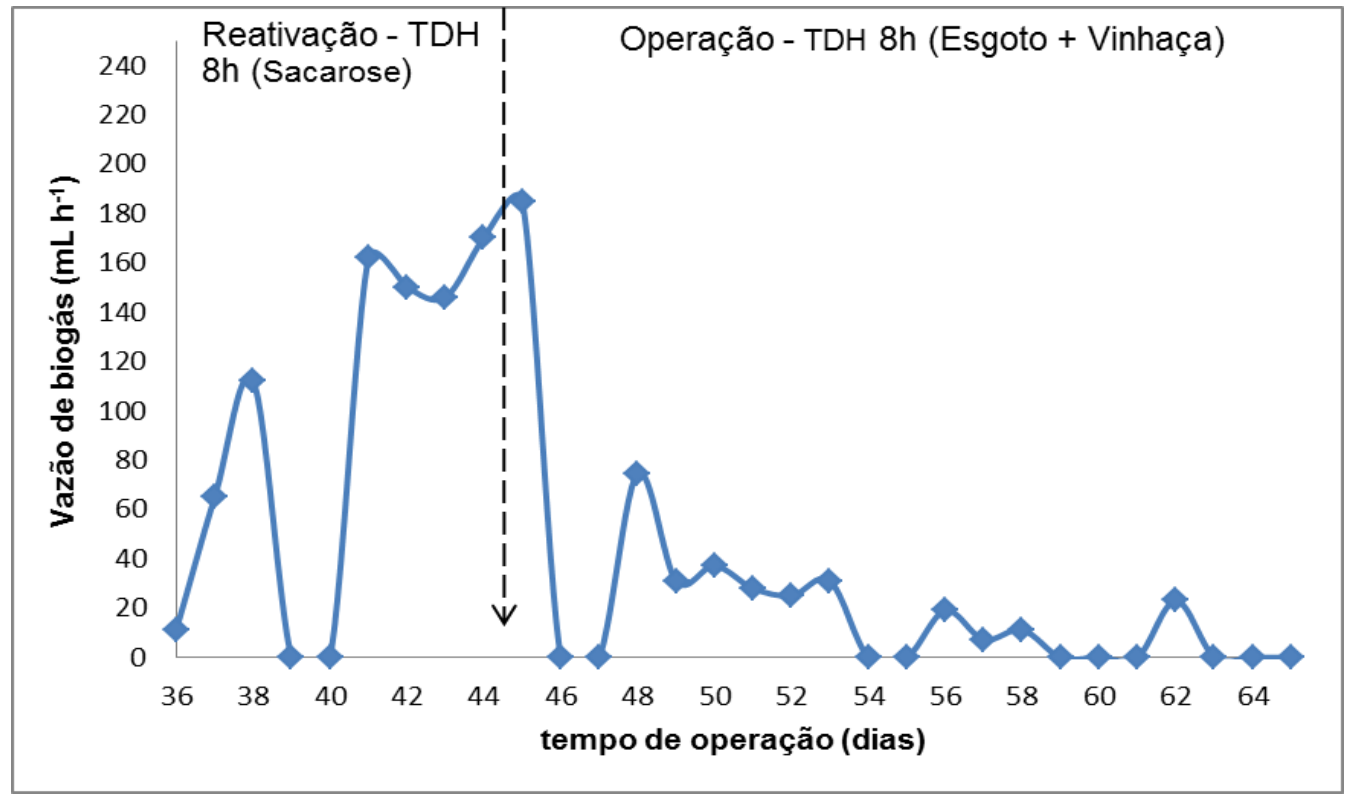

Figura 5.54 - Vazão de biogás no reator de cerâmica com TDH de 8h (Etapa 5).

A produção de biogás depois da reativação permaneceu oscilante, porém sem registrar rápida queda seguida da ausência de geração de biogás, como foi observado quando o reator foi operado com o TDH de $2 \mathrm{~h}$.

Neste sistema a produção média de biogás na reativação foi de $89,4 \mathrm{~mL} \mathrm{~h}^{-1}$ e 
19,6 mL h ${ }^{-1}$ no restante da operação. Provavelmente esta tendência, que também se delineou nos demais reatores (Figuras 5.44 e 5.48), ocorreu devido a alternância entre o meio de alimentação, que era preparado com água de abastecimento e a mistura de esgoto sanitário e vinhaça contendo diversas comunidades microbianas, com destaque para os microrganismos redutores de sulfato evidenciados pela detecção de sulfeto de hidrogênio e leveduras, que certamente influenciaram na composição do biogás, pois são em grande parte microrganismos que convertem os carboidratos em etanol e dióxido de carbono (Hamelinck et al. 2005), conforme mostra a reação 5.7 .

$\mathrm{C}_{6} \mathrm{H}_{12} \mathrm{O}_{6} \rightarrow 2 \mathrm{C}_{2} \mathrm{H}_{5} \mathrm{OH}+2 \mathrm{CO}_{2}$ Reação 5.7

As análises de microscopia do afluente e efluente desses reatores quando alimentados com esgoto sanitário e vinhaça mostraram diversas morfologias, dentre elas, algumas típicas de fungos e leveduras, conforme pode se observar nas Figuras 5.55 e 5.56 .

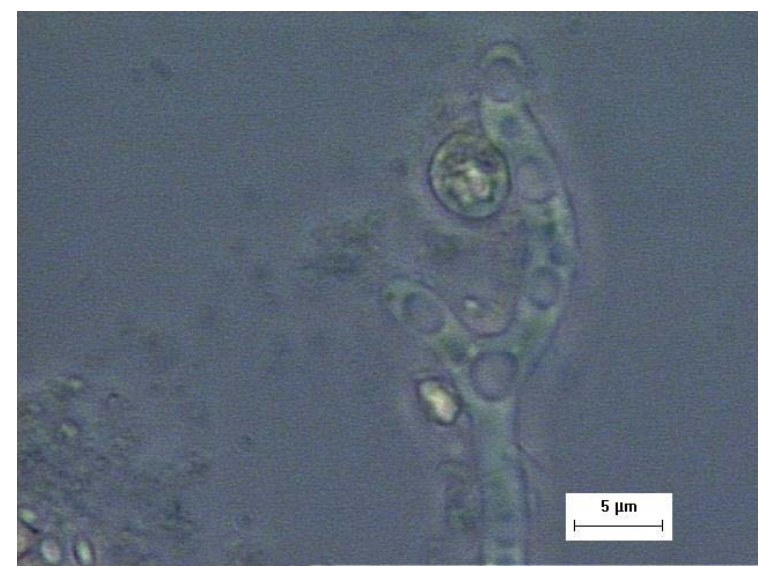

Figura 5.55 - Microscopia ótica do afluente aos reatores usados na Etapa 5. 


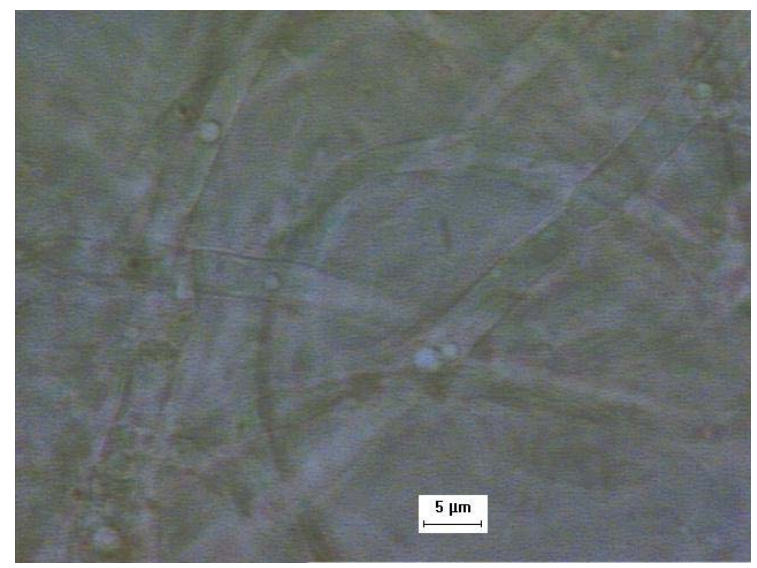

Figura 5.56 - Microscopia ótica do efluente aos reatores usados na Etapa 5.

Possivelmente esses microrganismos também atuaram negativamente sobre a produção de hidrogênio, pois assim como as bactérias redutoras de sulfato e as arqueias metanogênicas, os fungos e leveduras podem ter competido por substrato com as bactérias acidogênicas.

A influência do material suporte também pode ter sido um fator decisivo na seleção de microrganismos atuantes dentro dos sistemas.

Percebeu-se que neste reator com suporte de cerâmica operando com o TDH de 8 h e sendo alimentado com esgoto sanitário e vinhaça, houve produção de hidrogênio até o $56^{\circ}$ dia de operação, e essa foi a principal diferença entre os reatores com polietileno e espuma como suportes, já que os mesmos cessaram a produção de hidrogênio por volta do 50 dia de operação, conforme mostram as Figuras 5.45, 5.49 e 5.57 . 


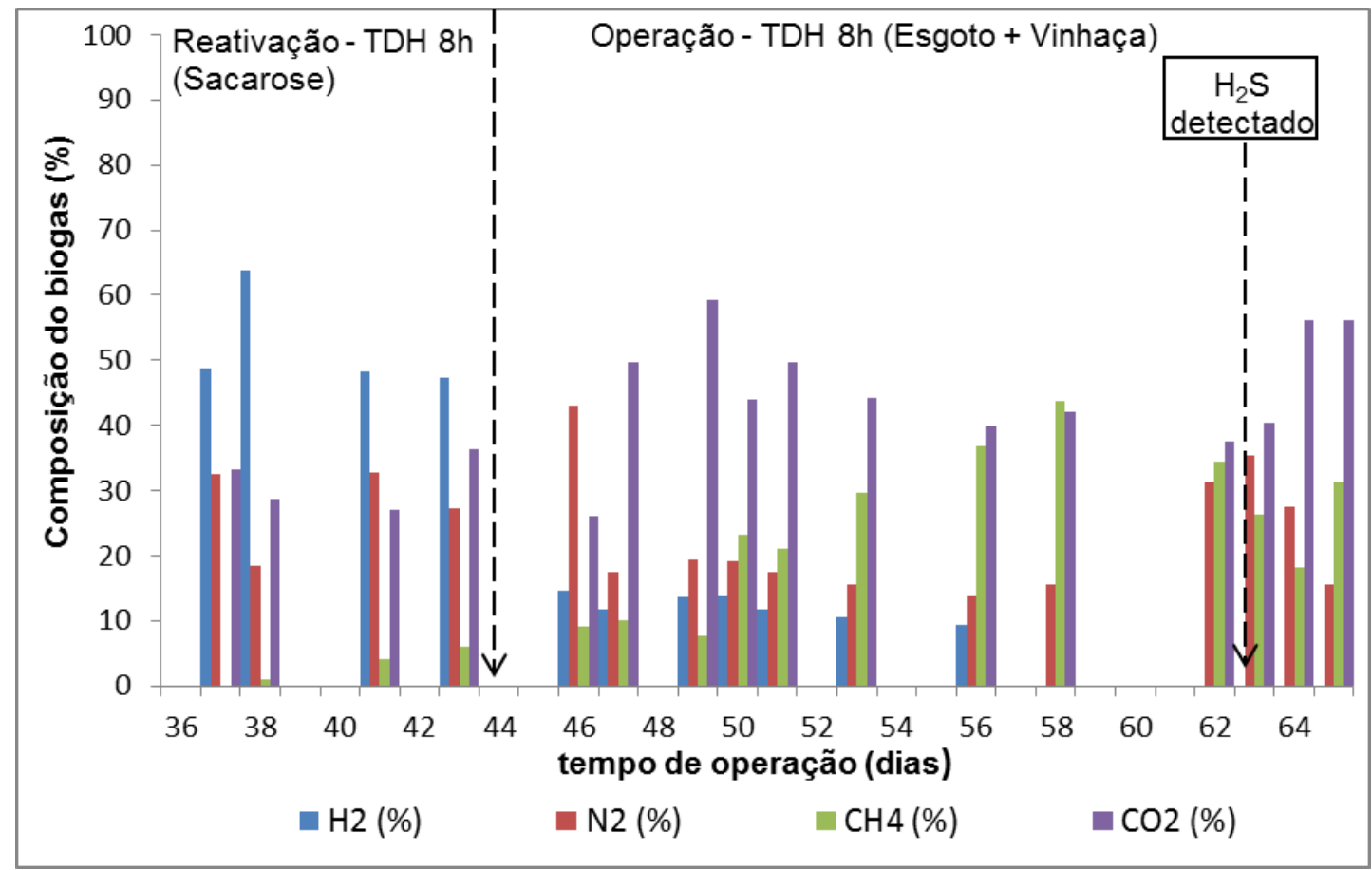

Figura 5.57 - Composição do biogás no reator de cerâmica com TDH de 8h (Etapa $5)$.

No estudo de Silva et al. (2006) foi avaliado o efeito da utilização de diferentes materiais suporte na adesão de bactérias redutoras de sulfato e arqueias metanogênicas. Esses autores constataram que a espuma de poliuretano e carvão vegetal foram bons para promover a adesão de bactérias redutoras de sulfato, a cerâmica foi interessante para promover micro-ambientes metanogênicos e o polietileno de baixa densidade para selecionar bactérias hidrolíticas e fermentativas

Os resultados obtidos neste trabalho mostraram concordância com os obtidos por Silva et al. (2006), uma vez que há a indicação que a espuma de poliuretano propiciou o desenvolvimento de bactérias redutoras de sulfato (BRS) bem antes dos demais materiais suporte (Figura 5.49).

A cerâmica provavelmente favoreceu a existência de micro-ambientes 
metanogênicos, conforme pôde-se observar nas detecções pontuais de metano no biogás apresentadas na Figura 5.57. Apesar disso, mostrou-se tão adequada quanto o polietileno para desfavorecer o estabelecimento de bactérias redutoras de sulfato, conforme de observa nas Figuras 5.45 e 5.57.

No final da operação de todos os reatores desta etapa, os materiais suporte puderam ser analisados e, constatou-se que as características de cada material haviam influenciado não apenas na seleção de microrganismos, como indicado nas composições do biogás e na microscopia, mas na capacidade de retenção de biomassa, que foi de 0,5311, 0,4924 e 0,3331 $\mathrm{g} \mathrm{SV} \mathrm{g}^{-1}$ material suporte para a espuma de poliuretano, a cerâmica e o polietileno de baixa densidade, respectivamente.

As Figuras 5.58, 5.59 e 5.60, mostram algumas das características dos leitos estruturados ao final da operação de cada reator.

Visualmente, a retenção de biomassa pareceu maior nos suportes de espuma de poliuretano, o que estaria em concordância com os resultados determinados por meio da quantificação dos sólidos voláteis aderidos nesse material. Por outro lado, os suportes de polietileno de baixa densidade parecem ter favorecido a formação de um biofilme plano, pois este material não apresentava uma superfície porosa. Já os suportes de cerâmica, demonstraram mais similaridade com os de espuma na incorporação da biomassa. 


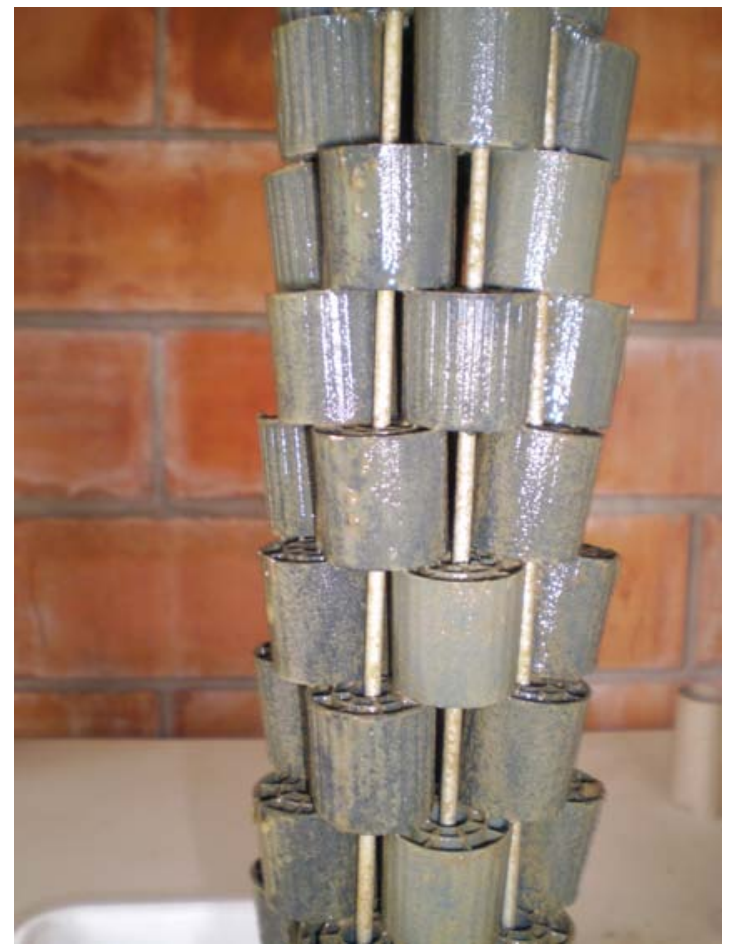

Figura 5.58 - Leito estruturado com polietileno de baixa densidade ao final da operação (Etapa 5).

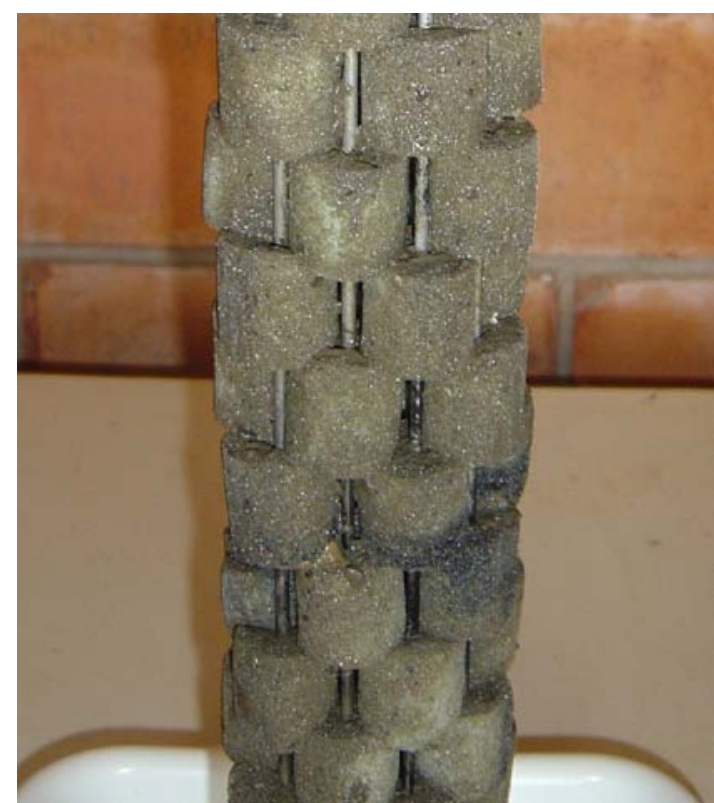

Figura 5.59 - Leito estruturado com espuma de poliuretano ao final da operação (Etapa 5). 


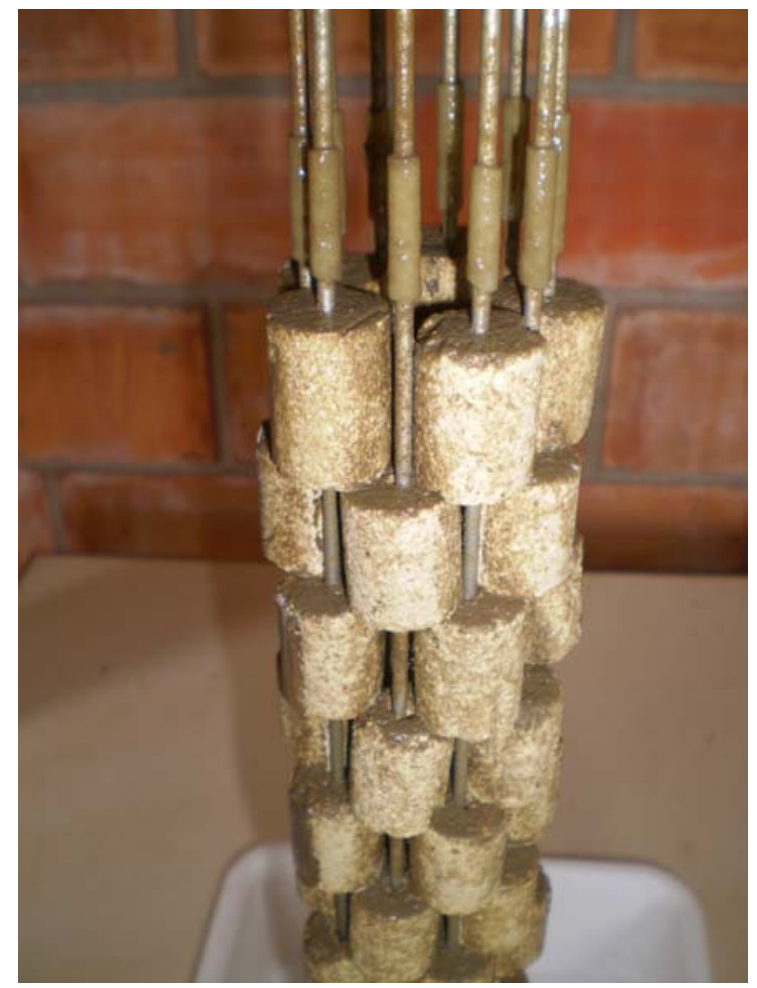

Figura 5.60 - Leito estruturado com cerâmica ao final da operação (Etapa 5).

É importante salientar que, visualmente, em nenhuma das operações com os reatores de leito estruturado alternado foi constatada a rápida colmatação do leito como a observada nos reatores de leito empacotado utilizados nas Etapas 1 e 2 deste Capítulo e em estudos anteriores (Fernandes, 2008; Peixoto, 2008; Rojas, 2010).

5.6 - Etapa 6 - Produção sequencial de hidrogênio e metano em um reator anaeróbio de leito estruturado com suportes de cerâmica e fluxo ascendente seguido por um reator anaeróbio de manta de lodo e fluxo ascendente (UASB)

Nesta etapa a hipótese testada foi de que a produção de hidrogênio a partir de esgoto sanitário suplementado com vinhaça, conforme verificado na Etapa 5, poderia 
ser realizada simultaneamente com a produção de metano em um reator anaeróbio de manta de lodo e fluxo ascendente, sequencial, por meio da utilização do efluente líquido do primeiro reator (acidogênico) como substrato para o segundo reator (metanogênico).

A condição operacional do reator acidogênico, tal como TDH de 8 h e o material suporte na forma de cilindros de cerâmica foram definidos na Etapa 5.

O reator UASB teve seu TDH fixado em $48 \mathrm{~h}$ desde a sua partida com esgoto sanitário, pois posteriormente seria integrado com o reator acidogênico fornecendo ácidos orgânicos e álcoois como substrato para a metanização.

Encontrou-se referência para a partida de reator UASB tratando vinhaça no trabalho de Viana (2006), o qual iniciou seu reator com o TDH médio de 2,14 dias, obtendo eficiências de remoção de DQO de 70,8 e 71,9\% com cargas de 0,73 e 3,08 g DQO L ${ }^{-1} \mathrm{~d}^{-1}$, respectivamente.

Utilizando o maior valor de concentração de DQO medida no efluente dos reatores da Etapa 5 (6,4654 $\left.\mathrm{g} \mathrm{L}^{-1}\right)$, estimou-se que o reator UASB desta etapa experimental receberia uma carga de até 2,94 g DQO $\mathrm{L}^{-1} \mathrm{~d}^{-1}$, que foi semelhante a utilizada por Viana (2006). Dessa forma, o reator UASB foi operado com TDH de 48 h durante todo o experimento.

O reator UASB apresentou inicialmente bons resultados de eficiência de remoção de matéria orgânica, produção e composição do biogás, conforme mostram as Figuras 5.61, 5.62 e 5.63. 


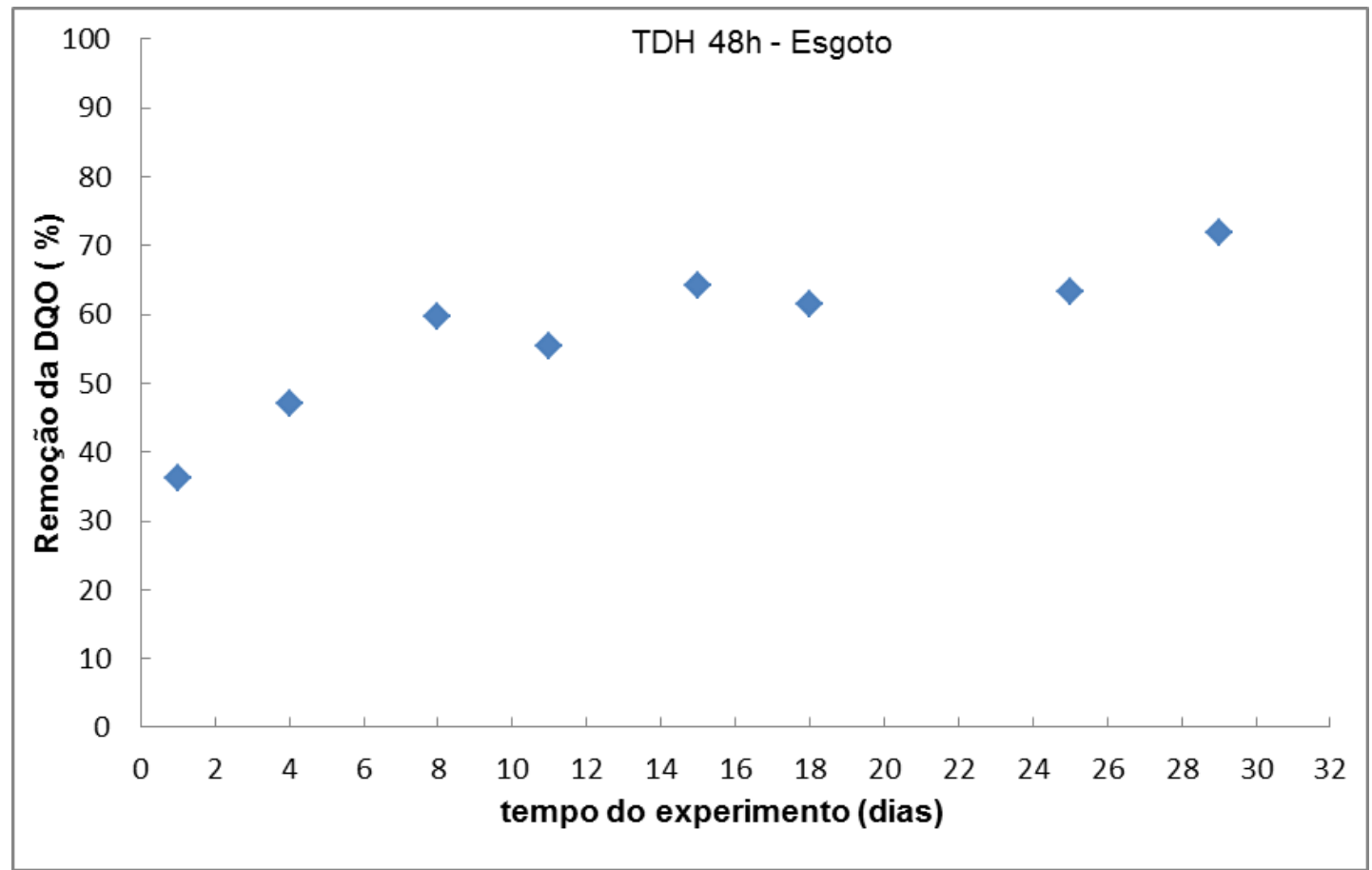

Figura 5.61 - Eficiência de remoção de matéria orgânica pelo reator UASB alimentado com esgoto sanitário (Etapa 6).

A Figura 5.61 mostra que a eficiência média de remoção de DQO filtrada do reator UASB no período em que foi operado com esgoto sanitário foi de $57 \pm 8 \%$. Essa eficiência poderia ter sido maior se as remoções mais baixas de matéria orgânica reportadas logo após a inoculação do reator fossem desconsideradas, contudo, a inoculação de $25 \%$ do volume útil do reator parece ter contribuído para a partida rápida do sistema e os resultados de estabilidade apresentados.

A Figura 5.62 mostra que a produção de biogás no reator UASB foi constante desde a inoculação, apresentando a média de $1,53 \pm 0,9 \mathrm{~mL} \mathrm{~h}^{-1}$.

A aparente estabilidade do reator UASB também se refletiu sobre a

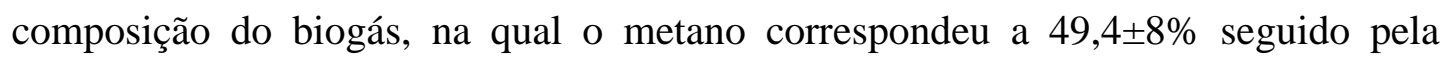
média de $31,7 \pm 12 \%$ de $\mathrm{CO}_{2}$ e $23,9 \pm 7 \%$ de $\mathrm{N}_{2}$, que era encontrado no headspace do 
reator devido a eventual entrada de ar dissolvido no esgoto sanitário durante o processo de captação deste afluente (Figura 5.63).

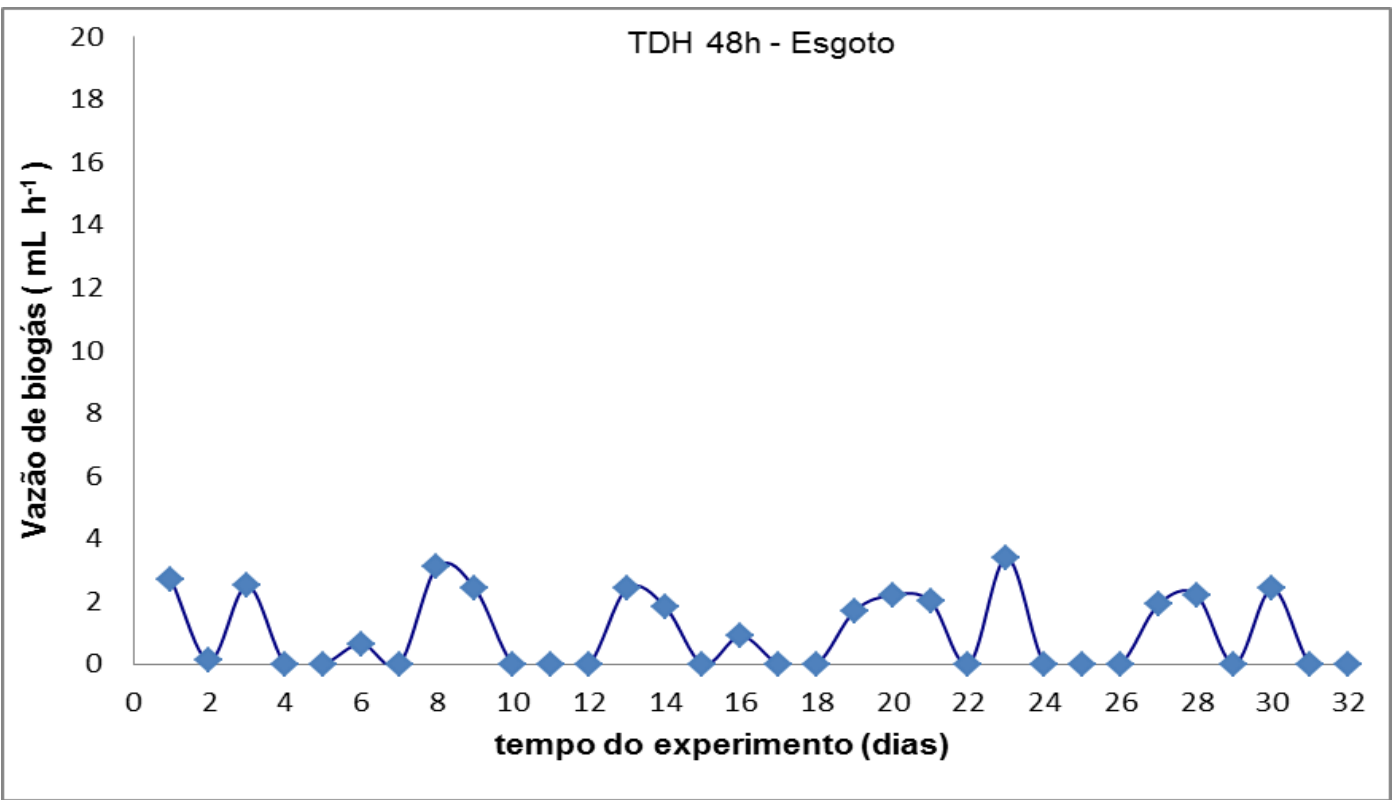

Figura 5.62 - Vazão de biogás do reator UASB alimentado com de esgoto sanitário (Etapa 6).

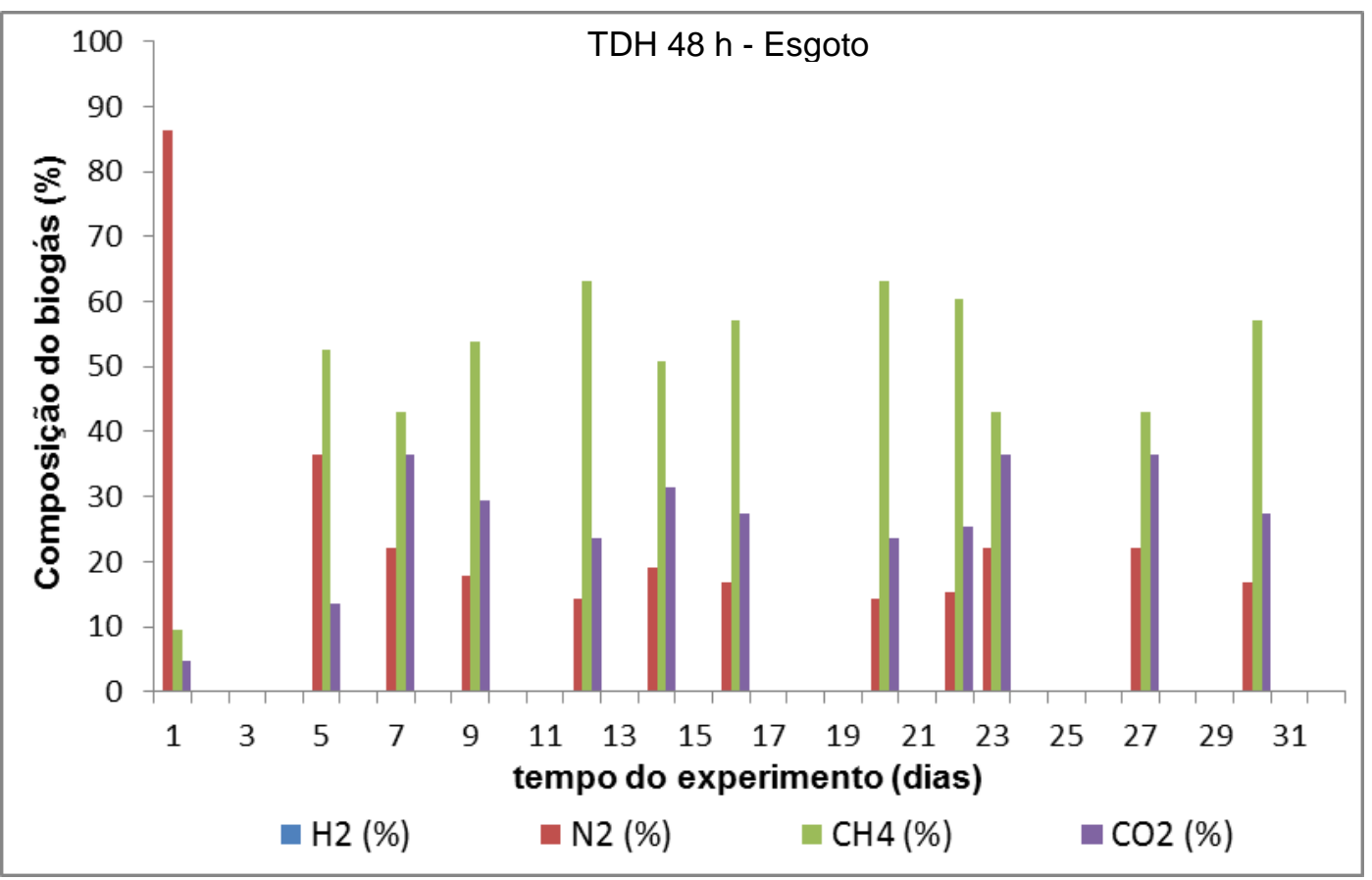

Figura 5.63 - Composição do biogás do reator UASB tratando esgoto sanitário (Etapa 6). 
De modo a evitar que o choque de carga orgânica volumétrica desequilibrasse o reator UASB e inviabilizasse rapidamente sua utilização para a metanização do efluente do reator acidogênico usando esgoto sanitário e vinhaça como substrato, acrescentou-se uma fase de operação intermediária, na qual o reator UASB teve como substrato o efluente do reator de leito estruturado usando o mesmo meio sintético utilizado por Rojas (2010), por 43 dias. Dessa forma cargas orgânicas volumétricas progressivas foram aplicadas ao reator UASB, conforme mostra a Tabela 5.8.

Tabela 5.8 - Descrição do substrato e cargas orgânicas volumétricas utilizadas em cada período de operação do reator UASB na Etapa 6.

\begin{tabular}{lcc}
\hline \multicolumn{1}{c}{ Substrato } & $\begin{array}{c}\text { COV } \\
\left(\mathrm{g} \mathrm{DQO} \mathrm{L}^{-1} \mathrm{~d}^{-1}\right)\end{array}$ & $\begin{array}{c}\text { Período } \\
\text { (dia de } \\
\text { operação) }\end{array}$ \\
\hline Esgoto sanitário & 0,19 & $1^{\circ}$ ao $32^{\circ}$ \\
Efluente do reator usando sacarose e nutrientes* & 0,91 & $33^{\circ}$ ao $73^{\circ}$ \\
Efluente do reator usando esgoto e vinhaça & 2,94 & $74^{\circ}$ ao $104^{\circ}$ \\
\hline *Calculado inicialmente com base na DQO de $2000 \mathrm{mg} \mathrm{L}^{-1}$ do afluente usado por Rojas (2010)
\end{tabular}

Conforme o procedimento experimental proposto, foi dada a partida no reator acidogênico de leito estruturado com suportes de cerâmica.

Este reator, operado com TDH de 8 h, produziu biogás de maneira constante, porém com queda acentuada quando passou a ser alimentado com a mistura de esgoto sanitário e vinhaça. 
As Figuras 5.64, 5.65, 5.66 e 5.67 permitem comparar as alterações decorrentes da mudança de alimentação com meio sintético para a mistura de esgoto sanitário e vinhaça no reator acidogênico.

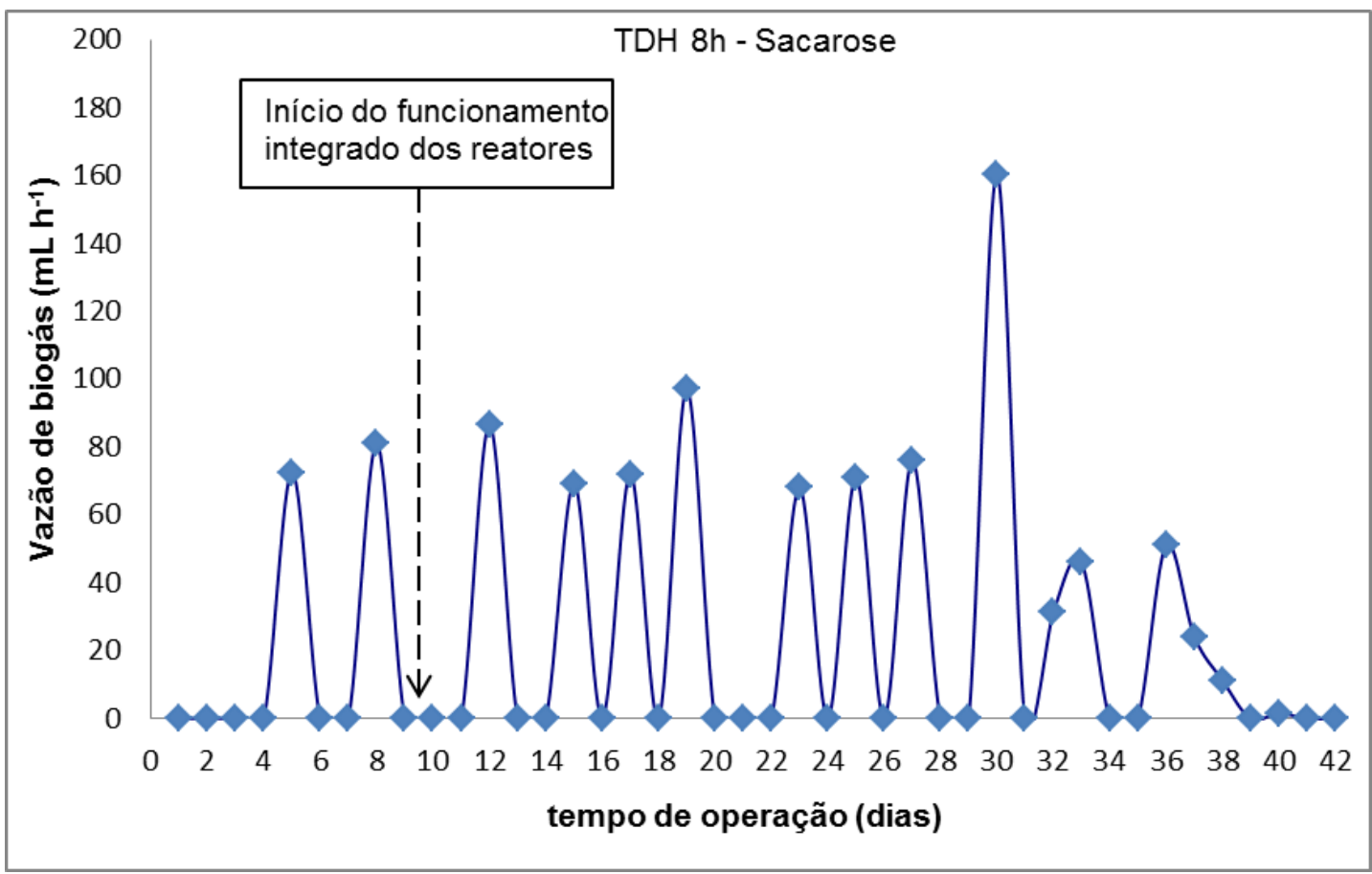

Figura 5.64 - Vazão de biogás no reator acidogênico alimentado com meio sintético (Etapa 6).

Conforme se nota na Figura 5.64 a produção de biogás permaneceu relativamente estável até o $30^{\circ}$ dia de operação e depois começou a mostrar um perfil de queda. Comportamento semelhante foi notado em operações com reatores produtores de hidrogênio a partir de sacarose no estudo de Rojas (2010), que aventou a possibilidade de desenvolvimento de microrganismos consumidores de hidrogênio no sistema no decorrer da operação.

Comparando-se os resultados das Figuras 5.65 e 5.66, notou-se um declínio na produção de biogás, desta vez devido a mudança do substrato na alimentação. 
Quando o reator parou de ser alimentado com meio sintético e passou a usar 50\% da vazão em esgoto sanitário e 50\% em vinhaça, a produção média de biogás caiu de $73,2 \pm 7 \mathrm{~mL} \mathrm{~h}^{-1}$ para $37,4 \pm 5 \mathrm{~mL} \mathrm{~h}^{-1}$. Esse efeito, assim como reportado na Etapa 5, provavelmente esteve ligado a muitos fatores, dentre eles a adaptação da biomassa produtora de hidrogênio a um substrato diferente, ao aporte de microrganismos consumidores de hidrogênio presentes no esgoto sanitário e competição por substrato com microrganismos como fungos e leveduras.

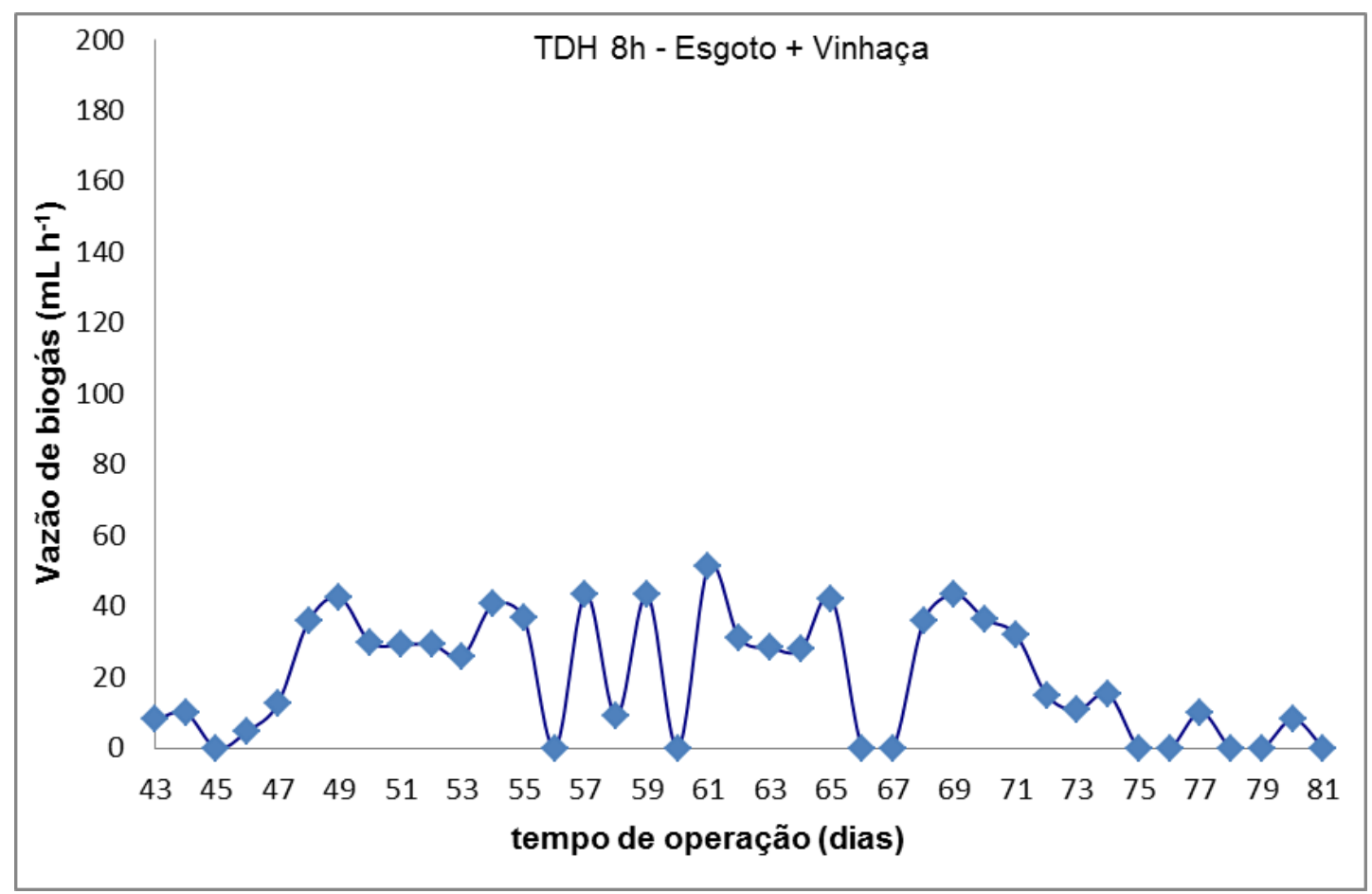

Figura 5.65 - Vazão de biogás no reator acidogênico após início da alimentação com esgoto e vinhaça (Etapa 6).

Comparando as Figuras 5.66 e 5.67 observa-se que a composição do biogás sofreu grandes alterações após a transição do uso de um substrato para o outro. A

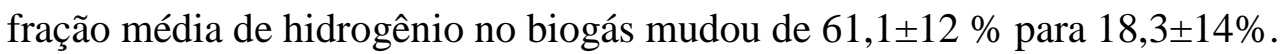




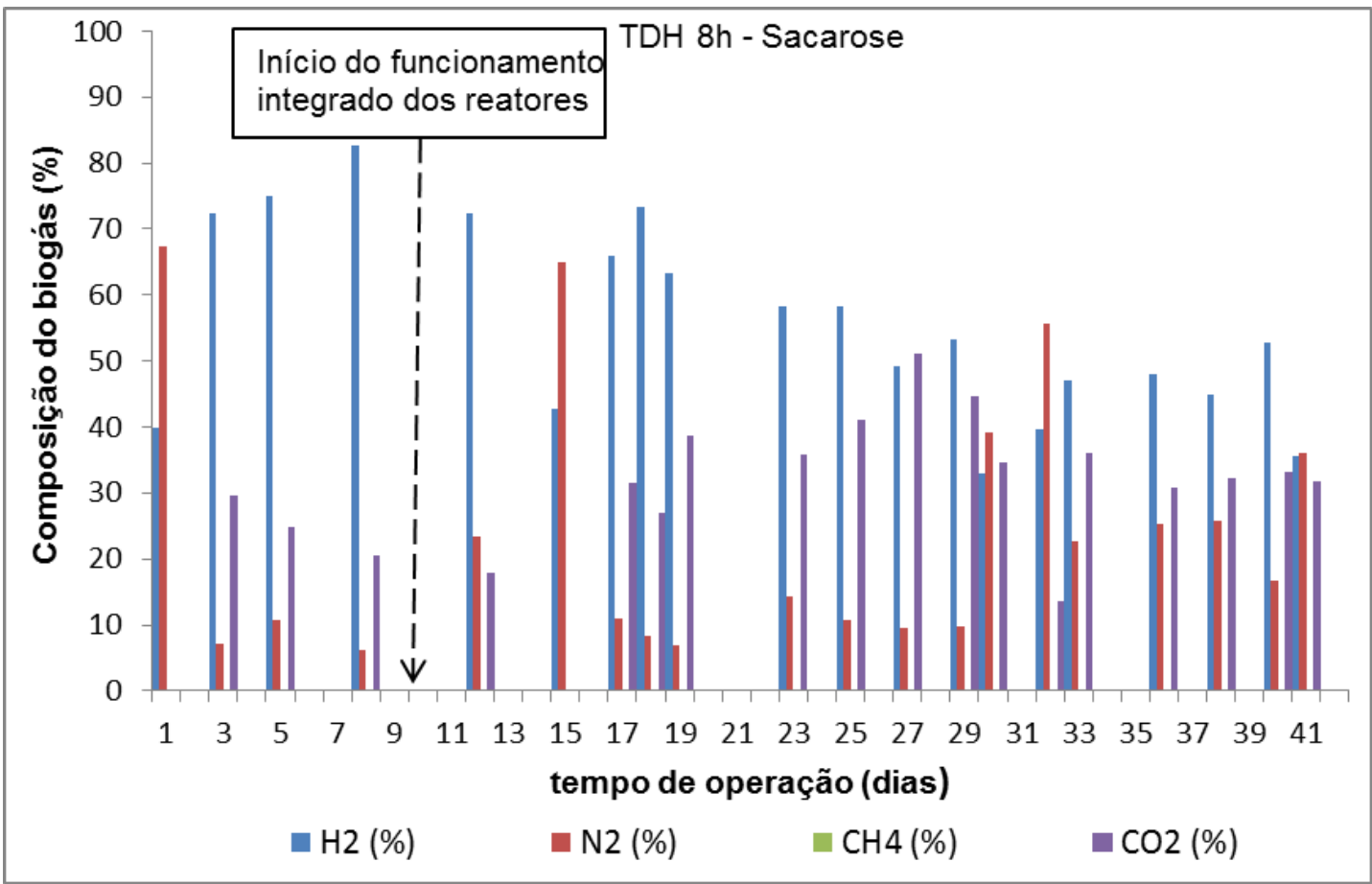

Figura 5.66 - Composição do biogás do reator acidogênico alimentado com solução de sacarose (Etapa 6).

Na Figura 5.67 nota-se que foi verificada produção de metano a partir do $54^{\circ}$ dia de operação em diante e detecção de $\mathrm{H}_{2} \mathrm{~S}$ na câmara a partir do $65^{\circ}$ dia de operação. 


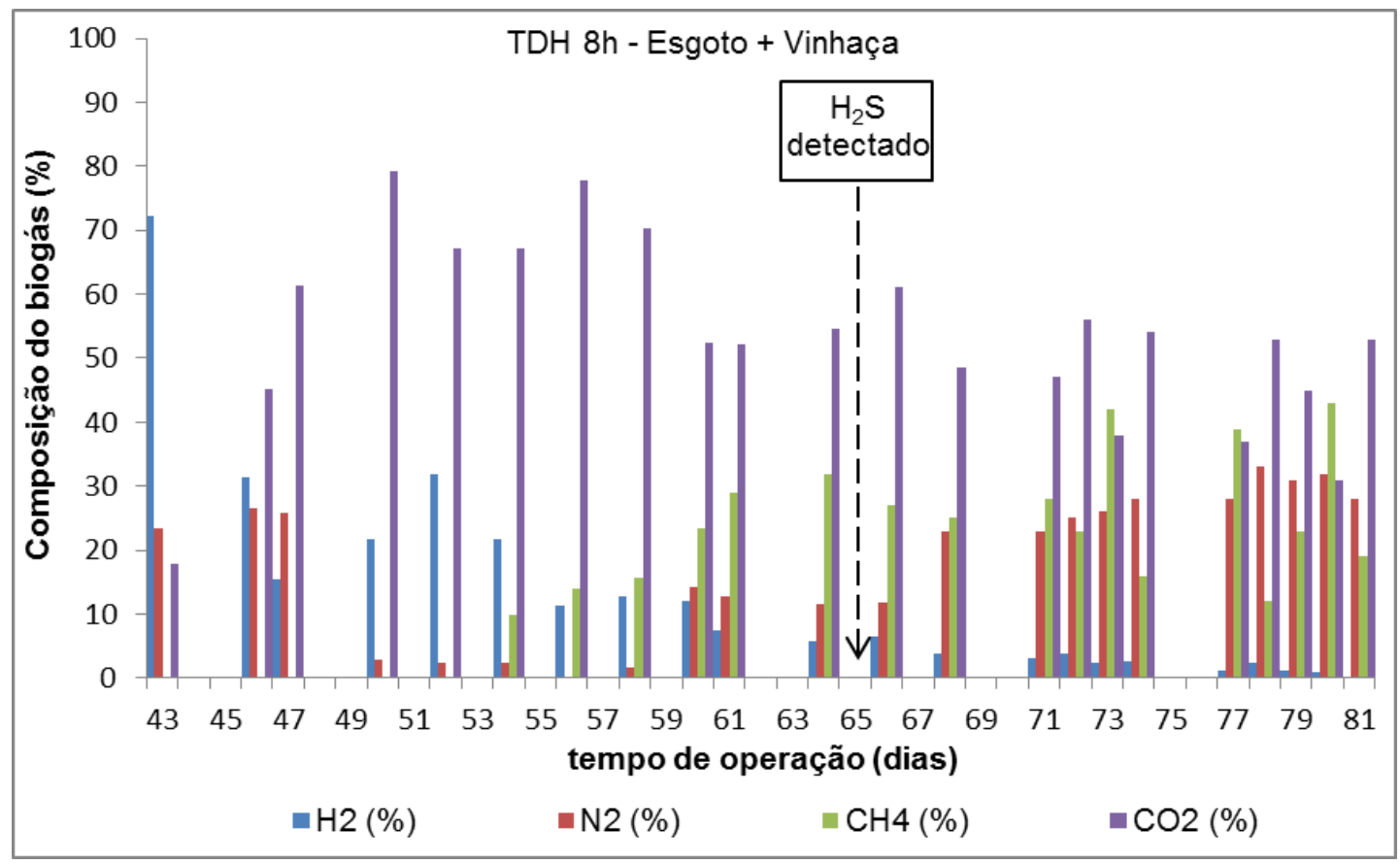

Figura 5.67 - Composição do biogás do reator acidogênico alimentado com esgoto sanitário e vinhaça (Etapa 6).

A integração do reator acidogênico com o reator metanogênico mostrada na Figura 5.68, ocorreu no primeiro dia de operação do reator acidogênico com o meio sintético, enquanto o reator metanogênico já se encontrava no seu $33^{\circ}$ dia de operação com esgoto sanitário.

É importante ressaltar que antes do efluente do reator acidogênico ser bombeado para o reator metanogênico, o mesmo passou por correção do pH com 1,6 g L $^{-1}$ de bicarbonato de sódio, ajustando-o para 7,2 , em média. 


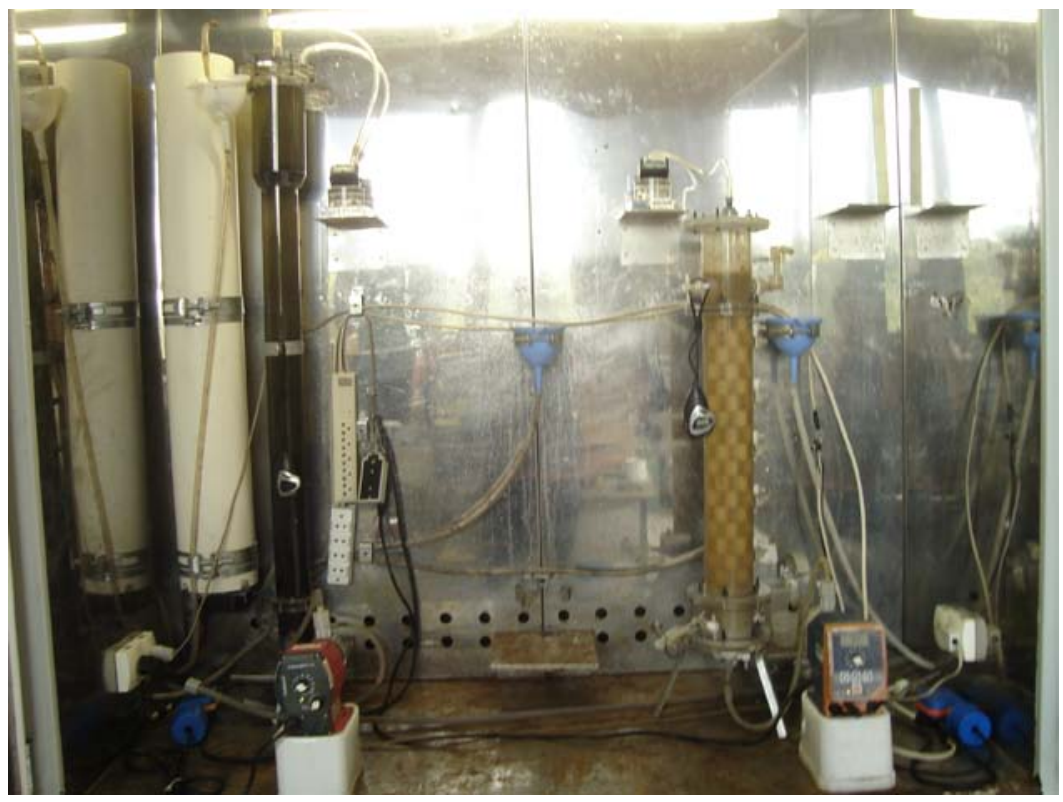

Figura 5.68 - Reatores metanogênico e acidogênico (esquerda para direita) acondicionados na câmara termostática para o início do funcionamento seqüencial na Etapa 6.

De acordo com a Figura 5.69, a mudança na vazão de biogás produzida pelo reator UASB foi bastante significativa, correspondendo a transição de 5,3 $\pm 1,2 \mathrm{~mL} \mathrm{~h}^{-1}$ quando alimentado pelo meio sintético degradado no reator acidogênico para 10,8 \pm 6 $\mathrm{mL} \mathrm{h}^{-1}$ quando o substrato foi a mistura de esgoto sanitário e vinhaça degradada no primeiro reator. 


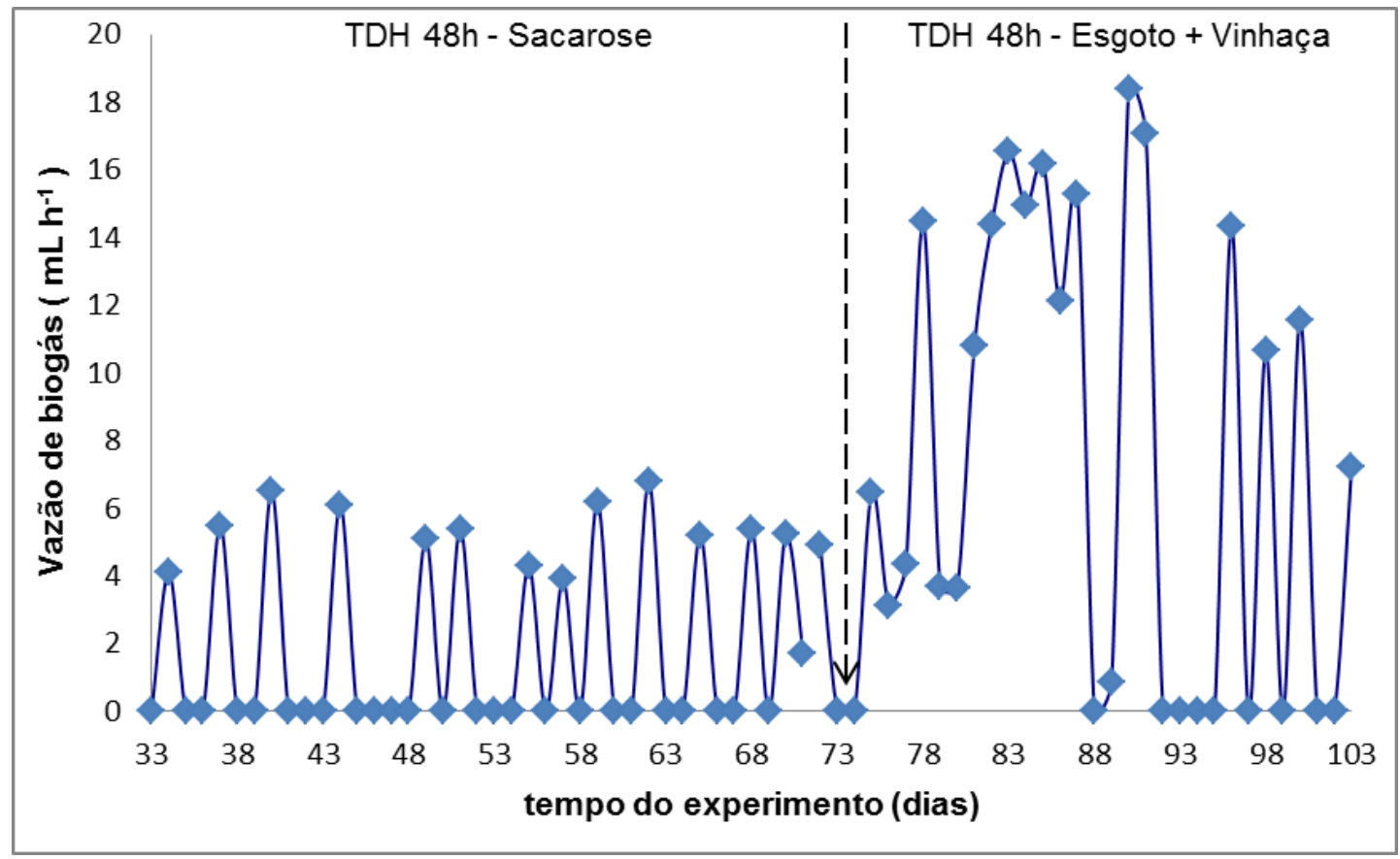

Figura 5.69 - Vazão de biogás no reator metanogênico integrado (Etapa 6).

É provável que este comportamento esteve relacionado com o aumento da carga orgânica volumétrica aplicada no reator UASB, conforme pode se notar na Figura 5.70, pois esta carga mudou de 0,83 $\pm 0,05$ para 2,62 $\pm 0,4$ g DQO L ${ }^{-1} \mathrm{~d}^{-1}$.

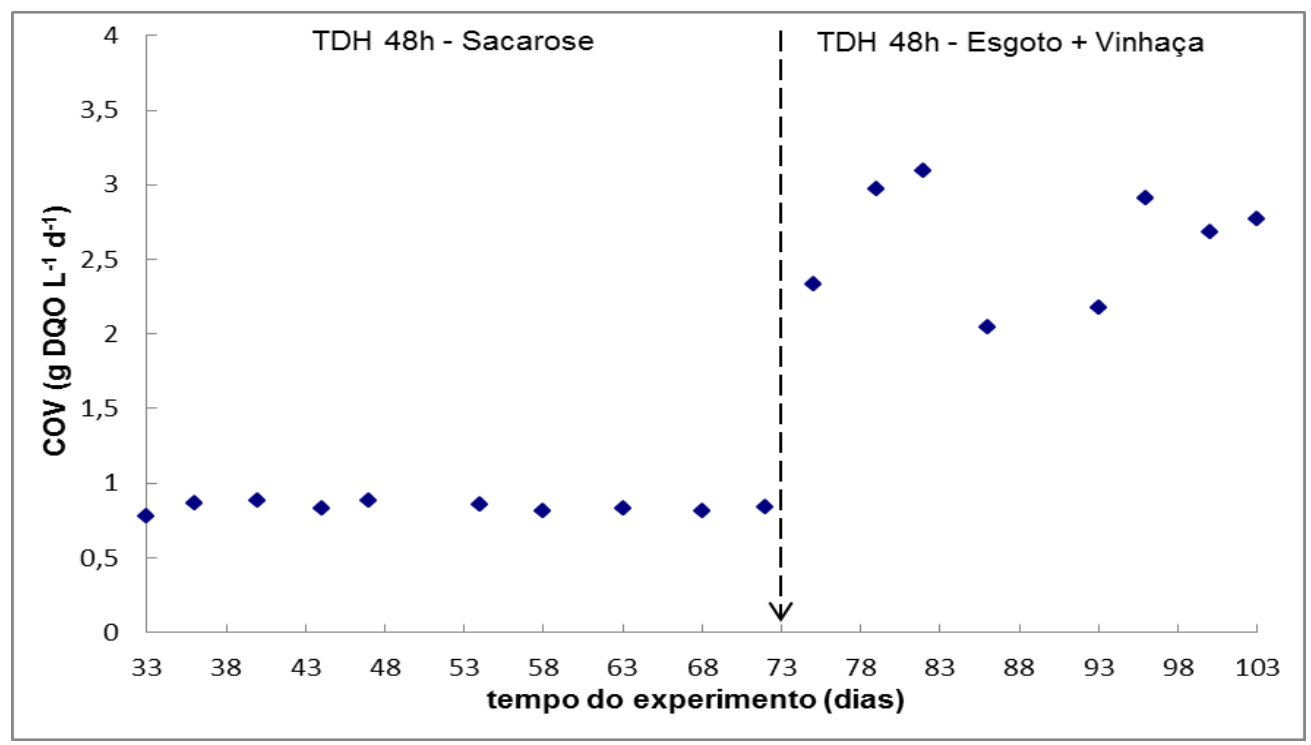

Figura 5.70 - Perfil de carga orgânica volumétrica aplicada ao reator UASB integrado (Etapa 6). 
Do $74^{\circ}$ ao $85^{\circ}$ dia de operação a alteração da carga orgânica volumétrica devido à mudança do substrato afluente ao reator UASB apresentou mudanças nos perfis de produção de biogás e composição do mesmo, ou seja, logo após o aumento da carga orgânica volumétrica de $0,83 \pm 0,05$ para 2,62 $\pm 0,4$ g DQO L ${ }^{-1} \mathrm{~d}^{-1}$.

Analisando as Figuras 5.69 e 5.71 após o $85^{\circ}$ dia de operação nota-se que tanto a vazão de biogás do $73^{\circ}$ ao $85^{\circ}$ dia de operação quanto a fração de metano no mesmo decresceram de $9,6 \pm 7$ para $4,67 \pm 3 \mathrm{~mL} \mathrm{~h}^{-1}$ e de $72,1 \pm 6$ para $55,2 \pm 8 \%$ , respectivamente.

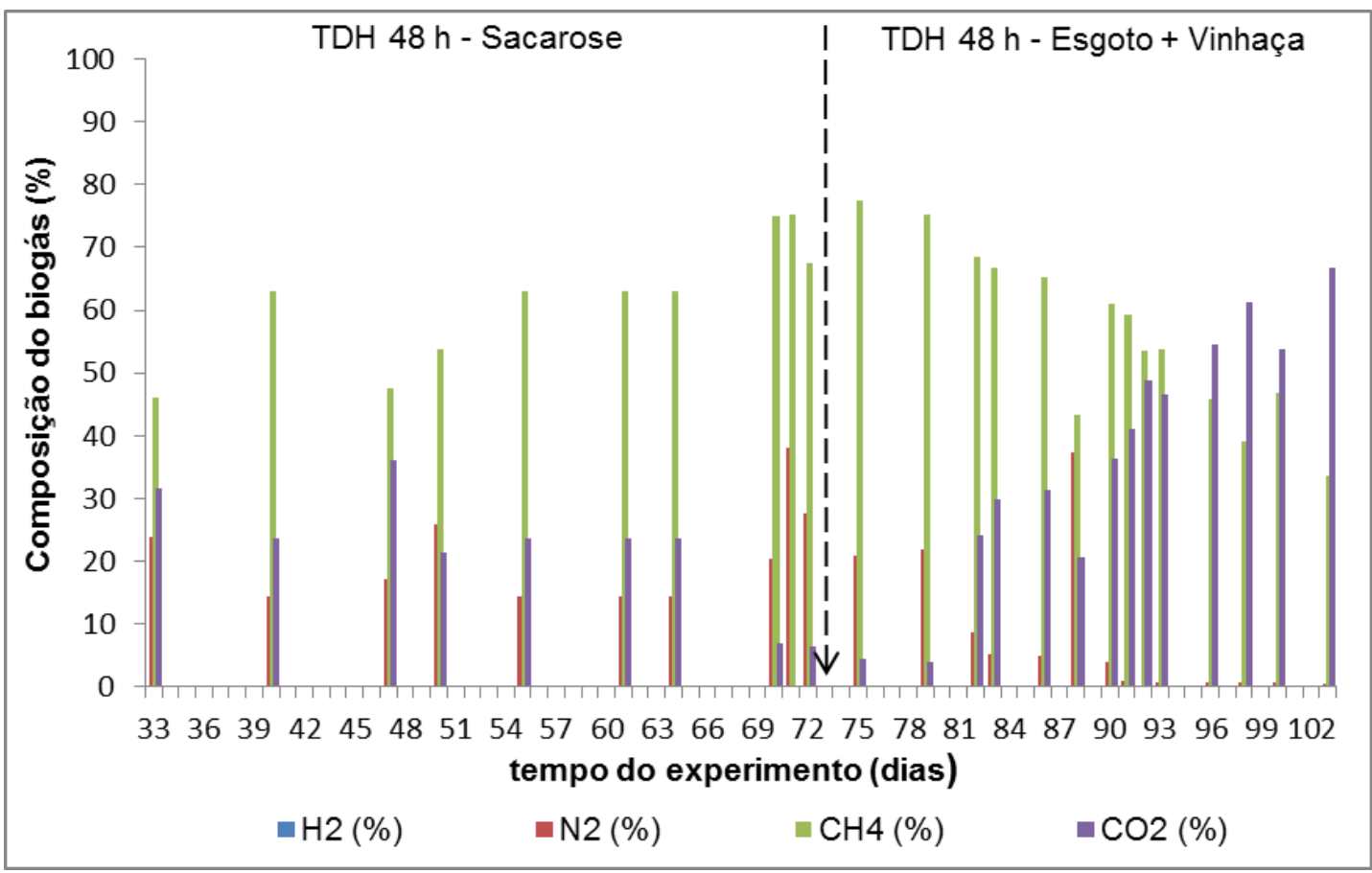

Figura 5.71 - Composição do biogás gerado no reator metanogênico integrado (Etapa 6).

Observou-se, principalmente, após o $86^{\circ}$ dia de operação, uma queda acentuada na eficiência de remoção de matéria orgânica, medida como a diferença 
entre a DQO filtrada afluente e a DQO filtrada efluente do reator UASB, conforme observado na Figura 5.72.

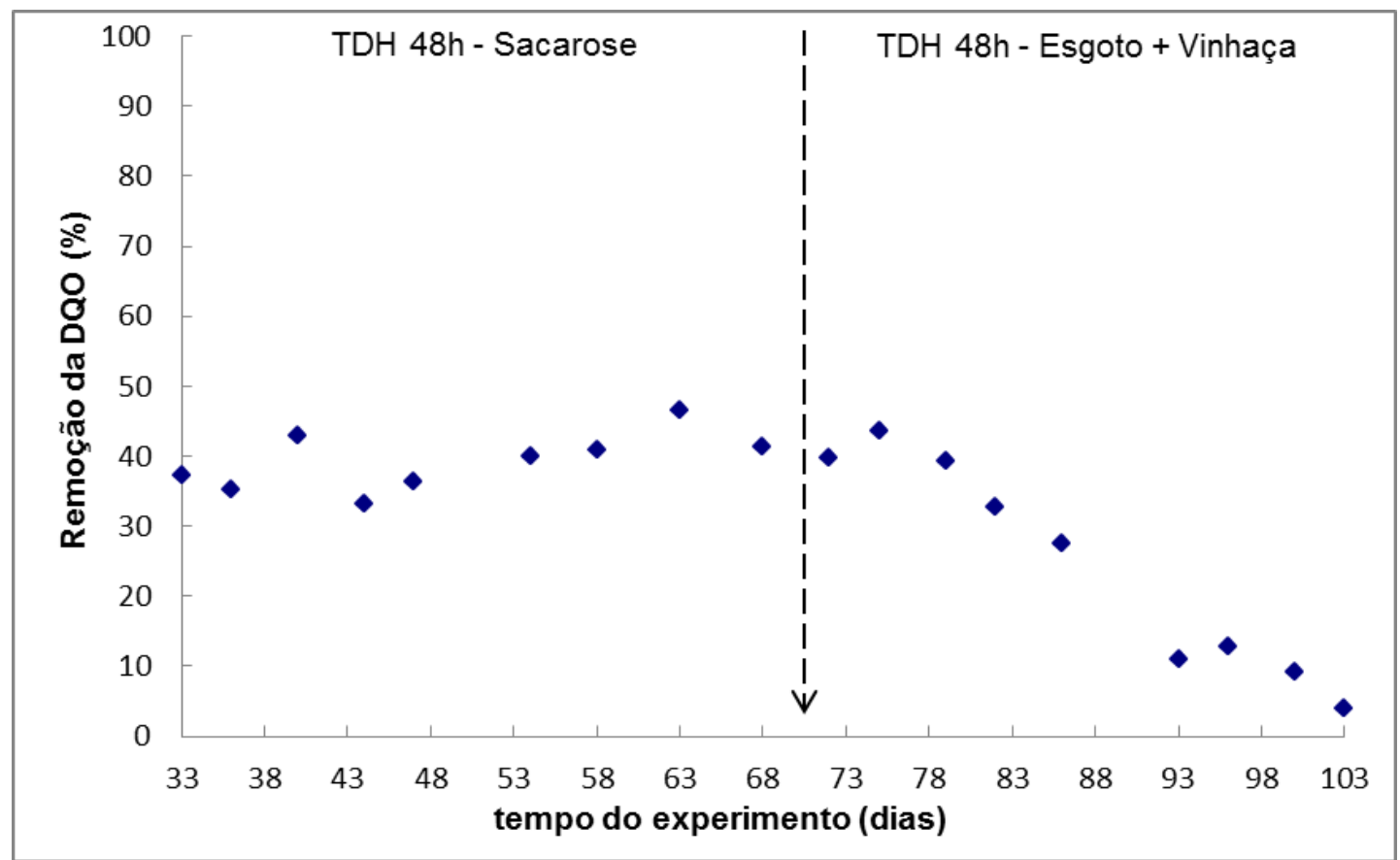

Figura 5.72 - Eficiência de remoção de matéria orgânica no reator UASB integrado (Etapa 6).

Diante da diminuição da eficiência de remoção de matéria orgânica de 43\% no $74^{\circ}$ dia de operação para $4 \%$ no $103^{\circ}$ dia de operação, inferiu-se que o reator esteve em processo de falência, principalmente porque o perfil mostrado na Figura 5.73 indicou que a partir do $73^{\circ}$ dia de operação, os ácidos orgânicos não foram degradados e acumularam-se no sistema.

Enquanto o reator UASB esteve operando com o substrato do reator acidogênico degradando meio sintético, ou seja, do $33^{\circ}$ ao $73^{\circ}$ dia de operação, a

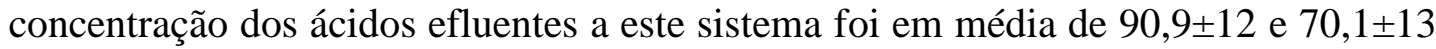
mg L ${ }^{-1}$ para o ácido acético e butírico, respectivamente. Por outro lado, quando o reator metanogênico recebeu como substrato o esgoto e vinhaça degradados no reator 
acidogênico ( $74^{\circ}$ a $104^{\circ}$ dias de operação), as concentrações efluentes médias de

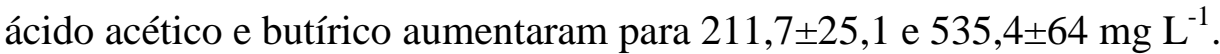

É importante ressaltar que o pH efluente do reator metanogênico também indicou o processo de acidificação do sistema, pois no $96^{\circ}, 100^{\circ}$ e $103^{\circ}$ dias de operação foi de 5,9, 5,8 e 5,4, respectivamente, sendo que o pH médio efluente antes

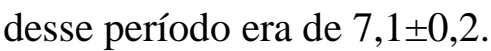

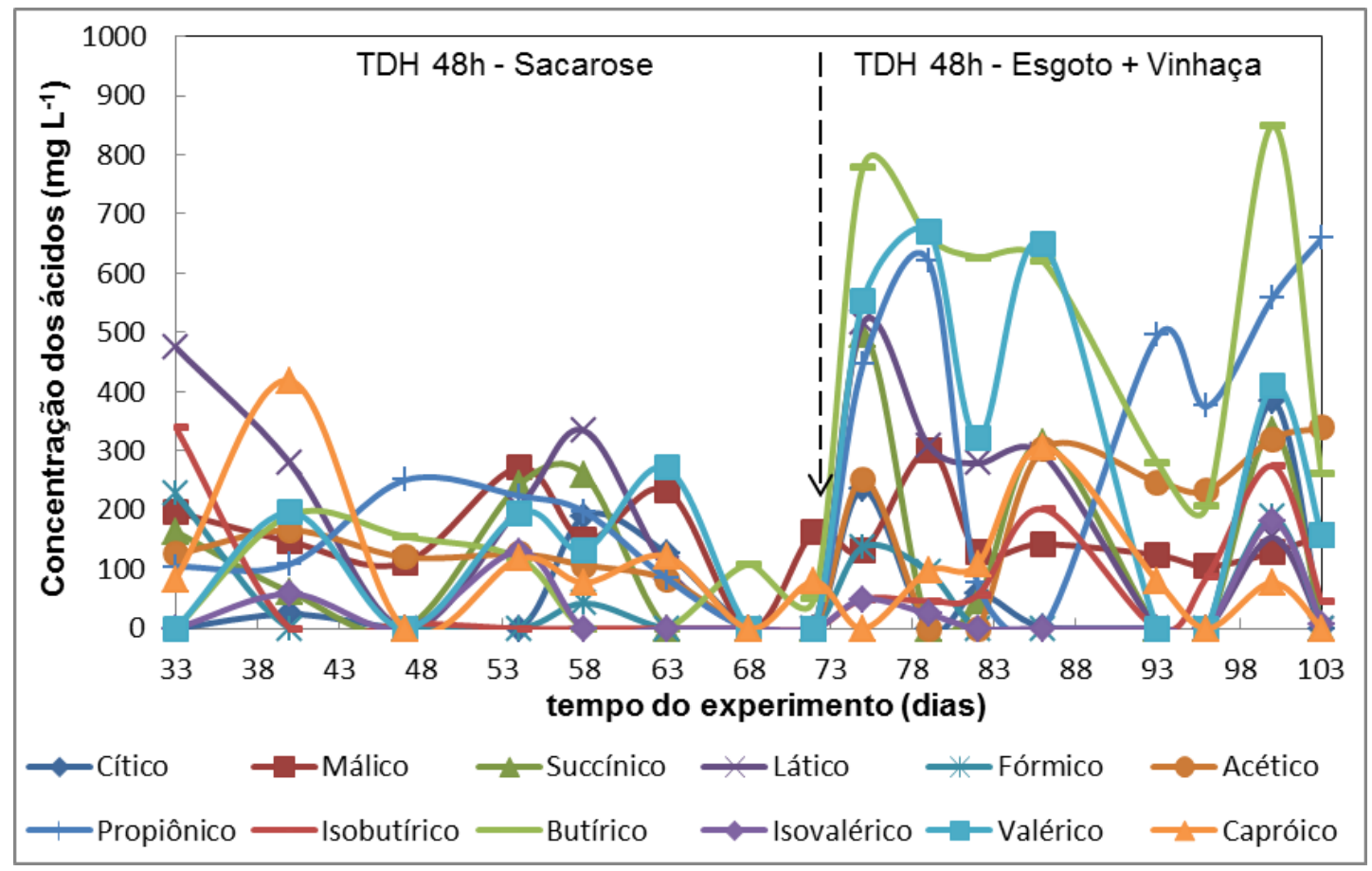

Figura 5.73 - Perfil temporal dos ácidos orgânicos efluentes do reator UASB integrado (Etapa 6).

Jimenéz et al. (2003) discutindo sobre o processo de degradação anaeróbia aponta que um dos parâmetros que mostra que o sistema está em equilíbrio é a concentração de ácidos voláteis tais como ácido fórmico, propiônico, butírico, valérico, isovalérico e capróico. Quando o sistema está em equilíbrio as arqueias metanogênicas usam os ácidos intermediários tão rapidamente quanto eles aparecem. 
Entretanto, se as metanogênicas não estão presentes em quantidades suficientes por alguma condição ambiental desfavorável, há o aumento na concentração de ácidos voláteis.

É provável que o reator tenha se desequilibrado não apenas pela mudança da carga orgânica volumétrica, pois quando foi feita a transição da alimentação com esgoto sanitário à COV de $0,19 \mathrm{~g}$ DQO $\mathrm{L}^{-1} \mathrm{~d}^{-1}$ para o efluente do reator acidogênico degradando meio sintético a COV de 0,91 g DQO $\mathrm{L}^{-1} \mathrm{~d}^{-1}$, o sistema não entrou em falência.

A causa mais provável é que a toxicidade intrínseca da vinhaça representada pelos compostos fenólicos reportados nos estudos de Pearson et al. (1980), Britz et al. (1992) e Jiménez et al. (2003), tenha afetado as arqueias metanogênicas, que são os microrganismos mais sensíveis do processo de digestão anaeróbia, com o agravante de que seu tempo de geração estimado é de 8 a 10 horas, enquanto as bactérias acidogênicas duplicam-se em aproximadamente 30 minutos. Logo, pode-se relacionar o desequilíbrio entre essas populações com as alterações sofridas pelo reator metanogênico apresentadas e nas Figuras 5.71, 5.72 e 5.73.

Possivelmente, se o reator UASB tivesse sido submetido a um TDH maior que 48 h e período de operação mais longo, a falência do sistema poderia não ocorrer. Entretanto, este sistema com TDH muito alto já não poderia ser considerado um reator de alta taxa. Logo, o parâmetro operacional que contribuiria para maior robustez seria a temperatura de operação na faixa termofílica $\left(55-65^{\circ} \mathrm{C}\right)$, pois segundo Wilkie et al. (2000) e Jiménez et al. (2003), a biodigestão termofílica da vinhaça proporciona eficiências de tratamento e rendimento de metano similar aos obtidos no tratamento mesofílico $\left(<42^{\circ} \mathrm{C}\right)$, porém com o dobro de carga orgânica 
afluente, na maioria dos casos.

Este resultado obtido com a integração do reator acidogênico produzindo hidrogênio a partir da mistura de esgoto sanitário e vinhaça e fornecendo efluente acidificado como substrato para um reator metanogênico subseqüente, pode ser considerado fruto de um grande esforço exploratório, uma vez que na literatura os poucos trabalhos mais representativos (Luo et al., 2011; Ueno et al., 2007; Cooney et al., 2007) utilizam-se de substratos controlados e menos contaminados que o esgoto sanitário para a produção de hidrogênio. Logo, como perspectiva futura de continuidade da pesquisa em produção de hidrogênio seguida de geração de metano, será necessário considerar a utilização de águas residuárias que favoreçam a estabilidade da produção de hidrogênio e atendam às limitações dos sistemas metanogênicos. Condições estas que não ocorreram neste estudo. 


\section{CAPÍTULO 6}

\section{CONCLUSÕES}

Os resultados obtidos com a realização dos estudos nas condições experimentais empregadas permitiram concluir que não foi possível produzir hidrogênio a partir de esgoto sanitário em reatores acidogênicos. Assim, a produção seqüencial de hidrogênio em reator acidogênico seguida da geração de metano em reator metanogênico a partir do efluente acidificado no primeiro reator não pôde ser realizada nas condições propostas inicialmente.

Com base nos demais resultados obtidos com o trabalho, as seguintes conclusões adicionais puderam ser tiradas:

- Hidrogênio foi produzido nos reatores anaeróbios de leito empacotado e fluxo ascendente a partir de esgoto sanitário suplementado por solução de sacarose, sendo que no meio de alimentação composto pelos dois substratos mencionados, a concentração mínima de carboidratos na forma de sacarose necessária para a ocorrência de produção volumetricamente mensurável de hidrogênio foi de $0,9 \mathrm{~g} \mathrm{~L}^{-1}$;

- Hidrogênio foi produzido a partir de água residuária de parboilização de arroz (23,9 $\mathrm{mL} \mathrm{H}_{2} \mathrm{~g}^{-1}$ DQO) e vinhaça (20,8 $\mathrm{mL} \mathrm{H}_{2} \mathrm{~g}^{-1}$ DQO) nos reatores em batelada com biomassa acidogênica; 
- Metano foi produzido a partir do efluente do estágio acidogênico em reatores em batelada com biomassa metanogênica a partir de esgoto sanitário (46,3 mL $\mathrm{CH}_{4} \mathrm{~g}^{-1}$ DQO), glicerol (180,1 mL CH $4 \mathrm{~g}^{-1}$ DQO), água residuária de parboilização de arroz (115,5 mL CH $\left.4 \mathrm{~g}^{-1} \mathrm{DQO}\right)$ e vinhaça (255,4 mL CH $\left.4 \mathrm{~g}^{-1} \mathrm{DQO}\right)$;

- Vinhaça foi o substrato que apresentou o melhor desempenho na produção seqüencial de hidrogênio e metano, pois alcançou velocidade de produção de hidrogênio de $0.84 \mathrm{~mL} \mathrm{~h}^{-1}$, velocidade máxima específica de produção de hidrogênio $2.94 \mathrm{~mL} \mathrm{H}_{2} \mathrm{~g}^{-1} \mathrm{SSV} \mathrm{h}^{-1}$ e rendimento na produção de metano de $255.44 \mathrm{~mL} \mathrm{CH}_{4} \mathrm{~g}^{-1}$ DQO nos reatores em batelada;

- Na faixa de 2000 a $10000 \mathrm{mg} \mathrm{L}^{-1}$ DQO, resultante da diluição da vinhaça no esgoto sanitário, a máxima concentração de DQO aplicável aos reatores em batelada foi de aproximadamente $4000 \mathrm{mg} \mathrm{L}^{-1}$, sem que o rendimento na geração de $\mathrm{H}_{2}$ pela biomassa acidogênica decrescesse.

- O TDH de 2 h mostrou-se inadequado para a manutenção da produção de hidrogênio em reatores de leito estruturado operados com a mistura de esgoto sanitário e vinhaça;

- O TDH de 8 h mostrou-se satisfatório quanto a manutenção da produção de biogás nos reatores anaeróbios de leito fixo estruturado. Entretanto, possivelmente houve o desenvolvimento de bactérias consumidoras de hidrogênio, principalmente as relacionadas com a formação de metano e sulfeto de hidrogênio; 
- Nos reatores anaeróbios de fluxo ascendente operados com TDH de 8 h para a produção de hidrogênio a partir de alimentação composta de 50\% esgoto e 50\% vinhaça, o material suporte na forma de cilindros de cerâmica foi o que apresentou os melhores resultados no tocante ao maior período de produção de $\mathrm{H}_{2}$ e maior fração do mesmo no biogás, o que correspondeu a 56 dias e 7,1\%, respectivamente.

- Foi possível produzir metano no reator UASB a partir do efluente do reator anaeróbio de leito estruturado com suportes de cerâmica usando esgoto sanitário suplementado com vinhaça na diluição de 1:1, porém por período de operação não superior a 7 dias.

- A produção de metano no reator UASB usando como substrato o efluente do reator acidogênico procedeu com estabilidade até a COV de 0,91 g DQO L $\mathrm{L}^{-1} \mathrm{~d}^{-1}$, porém se desestabilizou com a COV de 2,94 g DQO $\mathrm{L}^{-1} \mathrm{~d}^{-1}$, sendo esta última representada pelo efluente da degradação de esgoto sanitário e vinhaça, o qual ocasionou a queda na eficiência de remoção de DQO e na fração de metano no biogás de 43\% para 4\% e $76 \%$ para $36 \%$, respectivamente. 


\section{CAPÍTULO 7}

\section{SUGESTÕES}

Como sugestões para trabalhos futuros, têm se:

- Avaliar a produção de hidrogênio a partir de vinhaça em um reator anaeróbio de leito estruturado seguido de um reator UASB para a produção de metano, sendo os sistemas operados em condições termofílicas;

- Avaliar outras configurações de reator na produção de hidrogênio a partir de vinhaça;

- Avaliar a utilização de outros substratos menos contaminados por consórcios de microrganismos consumidores de hidrogênio na produção seqüencial de hidrogênio e metano;

- Estudar a dinâmica de conversão do substrato em reatores produzindo hidrogênio e metano em seqüência, a partir de água residuária a base de glicose;

- Avaliar o desempenho do reator anaeróbio de leito estruturado e fluxo ascendente com material suporte constituído de cerâmica na produção de hidrogênio a partir de sacarose, seguido de uma unidade de alta taxa na produção de metano; 


\section{CAPÍTULO 8}

\section{REFERÊNCIAS BIBLIOGRÁFICAS}

AMATO, G.W., CARVALHO, J.L.V., SILVEIRA, F. S. 2002. In: Ricardo Lenz (Ed). Arroz parboiled: tecnologia limpa, produto nobre, Porto Alegre, RS, Brazil, 240 p. (in portuguese)

ANTONOPOULOU G., GAVALA, H.N., SKIADAS, I.V., ANGELOPOULOS, K., LYBERATOS, G. 2008. Biofuels generation from sweet sorghum: fermentative hydrogen production and anaerobic digestion of the remaining biomass. Bioresource Technology, 99, 110-119.

ARGUN, H., KARGI F., KAPDAN, I. K., OZTEKIN, R. 2008. Hydrogen production by dark fermentation of wheat powder solution: Effects of $\mathrm{C} / \mathrm{N}$ and $\mathrm{C} / \mathrm{P}$ ratio on hydrogen yield and formation rate. International Journal of Hydrogen Energy, 33, 1813-1819.

BAHL, H.; ANDERSCH W.; BRAUN, K.; GOTTSCHALK, G. 1982. Effect of pH and butyrate concentration on the production of acetone and butanol by Clostridium acetobutylicum grown in continuous culture. Eur. J. Appl. Microbiol. Biotechnol., v. 14 , p. $17-20$. 
BARBIRATO, F., CHEDAILLE, D., BORIES, A.1997. Propionic acid fermentation from glycerol: comparison with conventional substrates. Appl. Microbiol. Biotechnol, 47, 411-416

BORJA, R., MARTÍN, A., ALONSO, V., GARCÍA, C.J., BANKS, C.J. 1995. Influence of different pretreatments on the kinetics of anaerobic digestion of olive mill wastewater. Water research, 29, 489-495.

BOWMAN, S. K.; MOE, M. W.; RASH, A. B.; BAE, S. H.; RAINEY A. F. 2006. Bacterial diversity of an acidic Louisiana groundwater contaminated by dense nonaqueous-phase liquid containing chloroethanes and other solvents. Federation of European Microbiological Societies, v. 58, p. 120-133.

BRITZ, T.J.; VAN DER MERWE, M.; RIEDEL, K-HJ. 1992. Influence of phenol additions on the efficiency of an anaerobic hybrid digester treating landfill leachate. Biotechnology Letters; 14: 323-328.

BUITRÓN, G., CARVAJAL, C. 2010. Biohydrogen production form Tequila vinasses in an anaerobic sequencing batch reactor: Effect of initial substrate concentration, temperature and hydraulic retention time. Bioresource Technology, 101, 9071-9077

CAMPOS, J.R.C (Org.) Tratamento de Esgotos Sanitários por Processo Anaeróbio e Disposição Controlada no Solo - Coletânea de Trabalhos Técnicos, PROSAB, 1999. 
Rio de Janeiro, RJ, 494 p.

CHABAN, B., SANDY, Y.M. NG., JARREL, K. F. 2006. Archeal habitats - from the extreme to the ordinary. Canadian Journal of Microbiology. 52: 73-116.

CAPUTO, HOMERO PINTO. Mecânica dos solos e suas aplicações, 1988.

CHANG, J. S.; LEE, K. C.; LIN, P. J. Biohydrogen production with fixed-bed bioreactors. 2002. Internacional Journal of Hydrogen Energy, v. 27, p. 1167-1174

CHANG, Y.C.; LIN, C. Y. 2004. Biohydrogen production using an upflow anaerobic sludge blanket reactor. International Journal of Hydrogen Energy, v. 29, p. 33 39.

CHEN, C. C.; LIN, C. Y.; CHANG, J. S. 2001. Kinetics of hydrogen production with continuous anaerobic cultures utilizing sucrose as the limiting substrate. Applied Microbiology Biotechnology, v. 57, p. 56-64.

CHEN, C. C.; LIN, C. Y. 2004. Using sucrose as a substrate in an anaerobic hydrogen-producing reactor. Advances in Environmental Research, v. 7, p. 695699, 2004.

CHEN, C. C.; LIN, C. Y.; LIN, M.C. 2002. Acid-base enrichment enhances anaerobic hydrogen production process. Appl Microbiol Biotechnol, v58 p 224-228 
CHEN, W.H., CHEN, S.Y., KHANAL, S.K., SUNG, S. 2006. Kinetic study of biological hydrogen production by anaerobic fermentation. International Journal of Hydrogen Energy, 31, 2170-2178.

CHERnICHARO, C. A. L. Reatores Anaeróbios - Princípio do Tratamento Biológico de Águas Residuárias - Vol. 5, 2ª Ed. Belo Horizonte, Departamento de Engenharia Sanitária e Ambiental, UFMG, 1997.

COONEY, M.; MAYNARD, N,; CANIZZARO, C.; BENEMANN, J. 2007. Twophase anaerobic digestion for production of hydrogen-methane mixtures. Bioresource Technology, v.98, p. $2641-2651$.

DAMASCENO, L. 2008. Degradação do aldicarbe em biorreator anaeróbio horizontal de leito fixo. Tese (Doutorado em Engenharia Hidráulica e Saneamento) Escola de Engenharia de São Carlos, Universidade de São Paulo,

DA SILVA, G. P., MACK, M., CONTIERO, J. 2009. Glycerol: A promising and abundant carbon source for industrial microbiology. Biotechnology Advances, 27, 30-39.

DAS, DEBABRATA.; VEZIROGLU T. N. 2001. Hydrogen production by biological processes: a survey of literature. International Journal of Hydrogen Energy, v .26, p. 13-28. 
DEL NERY, V. Digestão anaeróbia em duas Fases com culturas mistas acidogênicas e metanogênicas imobilizadas separadamente em gel agar. 1993. Tese (Doutorado em Engenharia Hidráulica e Saneamento) - Escola de Engenharia de São Carlos, Universidade de São Paulo, 1993.

DEL NERY, V. Utilização de lodo anaeróbio imobilizado em gel no estudo de partida de reatores de fluxo ascendente com manta de lodo. Dissertação (mestrado), Escola de Engenharia de São Carlos, USP, 1987.

DEL NERY, V., DE NARDI, I.R., DAMIANOVIC, M.H.R.Z., POZZI E., AMORIM, A.K.B., ZAIAT M. 2007. Long-term operating performance of a poultry slaughterhouse wastewater treatment plant. Resources, Conservation and Recycling, 50, 102-114.

DILLALO, R., ALBERTSON , O.E. 1961. Volatile acids by direct titration. Journal Water Pollution Control Federation, 33, 356-365.

DUBOIS, S. M.; GILLES, K. A.; HAMILTON, J. L.; REBERS, P. A.; SMITH, F. 1956. Colorimetric Methods for determination of sugar and related substance. Analytical Chemistry, v. 228, p. 13-21.

ENDO, G.; NOIKE, T.; MATSUMOTO, J. 1982. Characteristics of cellulose and glucose decomposition in acidogenic phase of anaerobic digestion. Proc. Soc. Civ. Engrs., v. 325, p. 61-68. 
EPAGRI. (Rural Extension and Agropecuary Research Business). Disponível em http://cepa.epagri.sc.gov.br/. Acessado em 29/05/2011.

FANG, H. P.; LIU, H. 2002. Effect of pH on hydrogen production from glucose by a mixed culture. Biores. Technol., v. 82, p. 87-93.

FANG, H.H.P., LI, C., ZHANG, T. 2006. Acidophilic biohydrogen production from rice slurry. International Journal of Hydrogen Energy, 31, 683-692.

FERNANDES, B. S. Produção de hidrogênio em reator anaeróbio de leito fixo. 2008. Tese (Doutorado em Engenharia Hidráulica e Saneamento) - Escola de Engenharia de São Carlos, Universidade de São Paulo.

FERNANDES, B.S., PEIXOTO, G., ALBRECHT, F.R., SAAVEDRA, N.K.D.A., ZAIAT M. 2010. Potential to produce biohydrogen from various wastewaters. Energy for Sustainable Development, 14, 143-148.

FERNANDES, B.S., VICH, D.V., IDAGAWA, R.H., VARESCHE, M.B., MARRA, W.D., ZAIAT, M. 2007. Influence of hydraulic retention time and support material for biomass immobilization on hydrogen production in an anaerobic packed-bed bioreactor. 11th World Congress Anaerobic Digestion, Bio-energy for Our Future, Brisbane.

GAFFRON, H.; RUBIN, J. Fermentative and photochemical production of hydrogen in algae. 1942. J Gen Physiol. v. 26, p. 219-240. 
GAO, D., AN, R., TAO, Y., LI, J., LI, X., REN, N. 2011. Simultaneous methane production and wastewater reuse by a membrane-based process: Evaluation with raw domestic wastewater. Journal of Hazardous Materials, 186, 383-389.

GIORDANO, A., CANTÙ, C., SPAGNI, A., RING, M. Y. 2011. The biochemical hydrogen and methane potential of the two-stage dark-fermentative process. Bioresource Technology, 102, 4474-4479.

GRADY, C.P.L., DAIGGER, G.T., LIM, H.C. 1999. Biological wastewater treatment, in: Marcel Dekker (Ed.) Biological nutrient removal, New York, pp. 487 [chapter 11].

GUJER, W., ZEHNDER, A.J.B., 1983. Conversion processes in anaerobic digestion. Water Science and Technology, 15, 127-167.

HAHN, J. J. Hydrogen production from biomass. 2006. Tese (doutorado) - Faculty of the Graduate School at the University of Missouri-Columbia, 116 p.

HAMELINCK, C. N.; HOOIJDONK, G. V.; FAAIJ, P. C. A. 2005. Ethanol from lignocellulosic biomass: techno-economic performance in short-, middle- and longterm. Biomass and Bioenergy. 28: 384-410.

HAN, S. K.; SHIN, H. S. 2004. Biohydrogen production by anaerobic fermentation of food waste. International Jounal of Hydrogen Energy, v. 29, p. 569-577. 
HANAKI, K., MATSUO, T., NAGASE, M. 1981. Mechanism of inhibition caused by long-chain fatty acids in anaerobic digestion process. Biotechnology Bioengeneering, 23, 1591-1610.

HANG-SIK SHIN, JONG-HO YOUNB, SANG-HYOUN KIM. 2004. Hydrogen production from food waste in anaerobic mesophilic and thermophilic acidogenesis. International Journal of Hydrogen Energy, 29: 1355 - 1363.

HARADA, H., UEMURA, S., CHEN A., JAYADEVAN, J. 1996 Anaerobic treatment of a recalcitrant distillery wastewater by a thermophilic UASB reactor. Bioresource Technology, 55, 215-221.

HAWKES, F. R.; DINSDALE, R.; HAWKES D. L.; HUSSY I. 2002. Sustainable fermentative hydrogen production: challenges for process optimization. International Journal of Hydrogen Energy, v. 27, p. 1339-47.

IBGE - Instituto Brasileiro de Geografia e Estatística. Pesquisa Nacional de Saneamento no Brasil (2000). Disponível em: <http://www.ibge.gov.br>. Acesso em: 05/10/2010.

IEA - International Energy Agency. The Goals of Energy Policy (2007). Disponível <http://catsearch.atomz.com/search/catsearch/?sp_a=sp10029401\&sp_f=ISO-88591\&sp_q=energy+demand+2030\&sp-p=all>. Acesso em 27/03/2008. 
IEA - International Energy Agency. IEA Energy Technology Essentials. Hydrogen Production \& Distribution. Disponível em http://www.iea.org/techno/essentials5.pdf Acesso em 30/05/2011.

ITO, T., NAKASHIMADA, Y., SENBA, K., MATSUI, T., NISHIO, N. 2005. Hydrogen and Ethanol Production from Glycerol-Containing Wastes Discharged after Biodiesel Manufacturing Process. Journal of bioscience and bioengineering, $100,260-265$.

JIMÉNEZ, A.M.; BORJA, R.; MARTÍN, A. 2003. Aerobic-Anaerobic biodegradation of beet molasses alcoholic fermentation wastewater. Process. Biochemistry. 38: 1275-1284.

JONES, W. J., GUYOT, J., WOLFE, R.S. 1984. Methanogenesis from Sucrose by Defined Immobilized Consortia, 47, 1-6

KAWAGOSHI, Y.; HINO, N; FUJIMOTO, A.; NAKAO M.; FUJITA Y.; SUGIMURA S.; FURUKAWA, K. 2005. Effect of inoculum conditioning on hydrogen fermentation and $\mathrm{pH}$ effect on bacterial community relevant to hydrogen production. Journal of Bioscience and Bioengineering, v. 100 (5), p. $524-530$. 
KHANAL, S. K.; CHEN, W. H.; LI, L.; SUNG, S. 2004. Biological hydrogen production: efects of $\mathrm{pH}$ and intermediate products. International Journal of Hydrogen Energy, v. 29, p. 1123-1131.

KOTHARI R.; BUDDHI, D.; SAWHNEY, R.L. 2006. Comparison of environmental and economic aspects of various hydrogen production methods. Renewable and Sustainable Energy Reviews.

LALOV, I. G., KRYSTEVA, M.A., PHELOUZAT, J. 2001.Improvement of biogas production from vinasse via covalently immobilized methanogens. Bioresource Technology, 79, 83-85 (Short Communication)

LAY JJ, FAN KS, CHANG J, KU CH. 2002. Influence of chemical nature of organic wastes on their conversion to hydrogen by heat-shock digested sludge. Int $\mathbf{J}$ Hydrogen Energy 2003;2008.

LAY, J. J.; LEE, Y. J.; NOIKE, T. 1999. Feasibility of biological hydrogen production from organic fraction of municipal solid waste. Water Research, v. 33 (11), p. 2579-2586.

LAY, J.J. 2000. Modeling and optimization of anaerobic digested sludge converting starch to hydrogen. Biotechnology and Bioengineering, 68, 269-278.

LEE, K. S.; LO, Y. S.; LO, Y. C.; LIN, P. J.; CHANG, J.S. 2003. H2 production with 
anaerobic sludge using activated-carbon supported packed-bed bioreactor. Biotechnology Letter, v. 25, p. 133-138, 2003.

LEITE, J. A. C.; FERNANDES, B.S.; POZZI, E.; BARBOZA, M.; ZAIAT M. 2008. Application of an anaerobic packed-bed reactor for the production of hydrogen and organic acids. International Journal of Hydrogen Energy. V.33: 579-586.

LENS, P.N.L.; VISSER, A.; JANSEN, A.J.H HULSHOFF POL, L.W.; LETTINGA, G. 1998. Biotecnological treatment of sulfate-rich wastewaters. Critical Reviews in Environmental Science and Technology. v. 28: 41-88.

LEVENSPIEL, O. Chemical reaction engineering. 3.ed. New York, John Wiley \& Sons Inc., 2000.

LEVIN, D. B.; PITT, L.; LOVE, M. 2004. Biohydrogen production: prospects and limitations to practical application. Internacional Journal of Hydrogen Energy, v. 29, p. 173-185.

LI, C.I.; FANG, H. H. P. 2007 Fermentative hydrogen production from wastewater and solid wastes by mixed cultures. Crit Rev Env Sci Technol, v.37, p.1-39 
LI, Y.F., REN, N.Q., CHEN, Y., ZHENG, G.X. 2007. Ecological mechanism of fermentative hydrogen production by bacteria. International Journal of Hydrogen Energy, 32, 755-760.

LIANHUA, L., DONG, L., YONGMING, S., LONGLONG, M., ZHENHONG, Y., XIAOYING, K. 2010. Effect of temperature and solid concentration on anaerobic digestion of rice straw in South China. International Journal of Hydrogen Energy, 35, 7261-7266.

LIN, C. Y.; LAY, C. H. 2004. Carbon/nitrogen-ratio effect on fermentative hydrogen production by mixed microflora. International Journal of Hydrogen Energy, v. 29, p. 41- 45.

LIN, C. Y.; LAY, C. H. 2004. Effect of carbonate and phosphate concentrations on hydrogen production using anaerobic sludge microflora. International Journal of Hydrogen Energy, v. 29, p. 275- 281.

LIU, H.; FANG, H. H. P. 2002. Hydrogen production from wastewater by acidogenic granular sludge. Water Science and Technology, v. 47(1), p. 153-158.

LO, Y. C., CHEN, W.M., HUNG C. H., CHEN S. D., CHANG J. S. 2008. Dark $\mathrm{H}_{2}$ fermentation from sucrose and xylose using $\mathrm{H}_{2}$-producing indigenous bacteria: Feasibility and kinetic studies. Water Research, 42, 827-842. 
LOGAN, B.; OH, S.E.; KIM, I.; VAN GINKEL, S.W. 2002 Biological Hydrogen Production Measured in Batch AnaerobicRespirometers. Environmental Science and Technology, 36, 2530-2535.

LÓPEZ, J. A. S., SANTOS, M. A. A., PÉREZ, A. F. C., MARTíN, A. M. 2009. Anaerobic digestion of glycerol derived from biodiesel manufacturing. Bioresource Technology. 100, 5609-5615.

MADIGAN, M.T.; MARTINKO, J.M \& PARKER, J. 2004. Microbiologia de Brock. $10^{\circ}$ edição. Editora Pearson Education do Brasil, São Paulo.

METCALF \& EDDY, 2003. Wastewater Engineering Treatment and Reuse. 4th Ed., McGraw Hill, New York.

MINTON N.P., CLARKE, D.J.1989. Biotechnology handbooks (PlenumPress), vol. 3: Clostridia. New York.

MIZUNO, O.; DINSDALE, R.; HAWKES, F. R.; HAWKES, D. L, NOIKE, T. 2000. Enhancement of hydrogen production from glucose by nitrogen gas sparging. Bioresour. Technology, v. 73(1), p. 59-65, 2000.

MOCKAITIS, G. 2007. Redução de sulfato em biorreator operado em batelada e batelada alimentada sequenciais contendo biomassa granulada com agitação mecânica e “draft-tube”. Dissertação (Mestrado em Engenharia Hidráulica e Saneamento) - Escola de Engenharia de São Carlos, Universidade de São Paulo. 
MOHAN, S.V., MOHANAKRISHNA, G., RAMANAIAH, S. V., SARMA, P.N. 2008. Simultaneous biohydrogen production and wastewater treatment in biofilm configured anaerobic periodic discontinuous batch reactor using distillery wastewater. International Journal of Hydrogen Energy. 33, 550-558.

NAGASE, M., MATUO, T. 1982. Interaction between amino-acid degrading bacteria and methanogenic bacteria in anaerobic digestion. Biotechnology Bioengeneering, 24, 2227-2239.

NAKAMURA, M.; KANBE, H.; MATSUMOTO, J. 1993. Fundamental study on hydrogen production in the acid-forming phase and its bacteria in anaerobic treatment process - the effects of solids retention time, Water Science and Technology, v. 28 (7), p. 81-88.

NIELSEN, A.; LIU, W. T.; FILIPE, C.; GRADY, L.; MOLIN, S.; STAHL. 1999. A. Identification of a novel group of bacteria in sludge from a deteriorated biological phosphorus removal reactor. Applied and Environmental Microbiology, v. 65 (3), p. $1251-1258$.

OKAMOTO, M., MYAHARA, T., MIZUNO, O., NOIKE T. 2000. Biological hydrogen potential of materials characteristic of the organic fraction of municipal solid wastes. Water Science and Technology, 41, 25-32. 
OLIVEIRA NETTO, A. P. 2007. Reator anaeróbio-aeróbio de leito fixo, com recirculação da fase líquida, aplicado ao tratamento de esgoto sanitário. Dissertação (Mestrado em Engenharia Hidráulica e Saneamento) - Escola de Engenharia de São Carlos, Universidade de São Paulo,

OLIVEIRA NETTO, A. P. 2011. Reator anaeróbio-aeróbio de leito fixo em escala piloto com recirculação da fase líquida, aplicado ao tratamento de esgoto sanitário. Tese (Doutorado em Engenharia Hidráulica e Saneamento) - Escola de Engenharia de São Carlos, Universidade de São Paulo,

PEARSON, F.; SHIUN-CHUNG, C.; GAUTIER, M. 1980. Toxic inhibition of anaerobic biodegradation. Journal of Water Polution Control Federation. 52: 472482.

PEIXOTO, G. Produção de hidrogênio em reator anaeróbio de leito fixo e fluxo ascendente a partir de água residuária de indústria de refrigerantes. 2008. Dissertação (Mestrado em Engenharia Hidráulica e Saneamento) - Escola de Engenharia de São Carlos, Universidade de São Paulo.

PEIXOTO, G., SAAVEDRA, N.K., VARESCHE M.B.A., ZAIAT, M. 2011. Hydrogen production from soft-drink wastewater in an upflow anaerobic packed-bed reactor. International Journal of Hydrogen Energy, 36, 8953-8966. 
RÊGO, V. M. S. 2002. Estudo da atividade biológica das células imobilizadas em um reator anaeróbio tratando esgoto sanitário. Dissertação (Mestrado em Engenharia Hidráulica e Saneamento) - Escola de Engenharia de São Carlos, Universidade de São Paulo.

RIPLEY, L.E.; BOYLE, W.C.; CONVERSE, J.C. 1986. Improved alkalimetric monitoring for anaerobic digestion of high strength wastes. Journal Water Pollution Control Federation. 58, 406-411.

ROJAS, M. D. P. 2010. Influência da relação C/N na produção de hidrogênio em reator anaeróbio de leito fixo. Dissertação (Mestrado em Engenharia Hidráulica e Saneamento) - Escola de Engenharia de São Carlos, Universidade de São Paulo.

SARTI, E.L. 2007. Influência do oxigênio no crescimento de arqueias metanogênicas e bactérias redutoras de sulfato em reatores anaeróbios em batelada. Dissertação (Mestrado em Engenharia Hidráulica e Saneamento) - Escola de Engenharia de São Carlos, Universidade de São Paulo,

SCHRÖDER, U., SCHOLZ, F., 2003. Bacterial batteries. Nature Biotechnology, v. 21(10), p. 1151-1152.

SEIFERT, K., WALIGORSKA, M., WOJTOWSKI, M., LANIECKI, M. 2009. Hydrogen generation from glycerol in batch fermentation process. International Journal of Hydrogen Energy, 34, 3671-3678 
SHIN, J. H., YOON, J. H.; AHN, E. K.; KIM, M. S.; SIM, S. J.; PARK, T. H. 2007. Fermentative hydrogen production by the newly isolated Enterobacter asburiae SNU-1. International Journal of Hydrogen Energy, v.32, p. 192-199.

SILVA, J.S. HIRASAWA, M.B. VARESCHE, E. FORESTI, M. ZAIAT. 2006. Evaluation of support materials for the immobilization of sulfate-reducing bacteria and methanogenic archea, Anaerobe. v12: 93-98

SREETHAWONG, $\quad$ T., $\quad$ CHATSIRIWATANA, S.,RANGSUNVIGIT, P., CHAVADEJ, S. 2010. Hydrogen production from cassava wastewater using an anaerobic sequencing batch reactor: Effects of operational parameters, COD: $\mathrm{N}$ ratio, and organic acid composition. International Journal of Hydrogen Energy, 35, 4092-4102.

STANDARD METHODS FOR THE EXAMINATION OF WATER AND WAStewAter. 21st ed. American Public Health Association / American Water Works Association / Water Environment Federation, Washington, DC, USA, 2005.

STENERSON, K. 2004. Analysis of Permanent Gases. The Reporter. 3(1), 3.

STOJIC', D. L.; MARCETA, M. P.; SOVILJ, S. P., MILJANIC', S. S. 2003. Hydrogen generation from water electrolysis - possibilities of energy saving. Journal of Power Sources, v. 118, p. 315-319. 
TCHOBANOGLOUS, G., BURTON, F. L., STENSEL, H.D. 2003. Wastewater engineering: treatment and reuse - Metcalf \& Eddy Inc. fourth ed. McGraw Hill, New York.

THAUER, R.K., JUNGERMANN, K., DECKER, K. 1977. Energy conservation in chemotrophic anaerobic bacteria. Bacterial Rev, 1, 100-180.

UENO, Y.; FUKUI, H.; GOTO, M. 2007. Operation of a two-stage fermentation process producing hydrogen and methane from organic waste. Environ. Sci. Technol. v. 41, p. $413-1419$.

UENO, Y.; OTSUKA, S.; MORIMOTO, M. 1996. Hydrogen Production from Industrial Wastewater by Anaerobic Microflora in Chemostat Culture. Journal of Fermentation and Bioengineering, v.82, p. 194-197.

UNICA. (Sugarcane Agroindustry Union of São Paulo State). Disponível em: http://www.unica.com.br/dadosCotacao/estatistica/. Acesso em 29/05/2011.

VAN GINKEL, S. W.; OH, S. E.; LOGAN, B. E. 2005. Biohydrogen gas production from food processing and domestic wastewaters. International Journal of Hydrogen Energy, v. 30, p. 1535-1542. 
VAN GINKEL, S. W.; SUNG, S.; LAY, J. J. 2001. Biohydrogen production as a function of $\mathrm{pH}$ and substrate concentration. Environmental Science and Technology, v. 35, p. 4719-4725.

VIANA, A.B. 2006. Tratamento anaeróbio de vinhaça em reator UASB operado em temperatura na faixa termofílica (55 C) e submetido ao aumento progressivo de carga orgânica. Dissertação (Mestrado em Engenharia Hidráulica e Saneamento) - Escola de Engenharia de São Carlos, Universidade de São Paulo.

VIEIRA, S. M. M., GARCIA JR, A. D. 1991, Sewage treatment by UASB reactor Operation results and recomendations for design and utilization. In : INTERNATIONAL SYMPOSIUM ON ANAEROBIC DIGESTION, 6, São Paulo, 12-16 may, 1991. Proceedings... São Paulo : ABES, 1991. p.133-144.

VIJAYARAGHAVAN, K.; SOOM, M. A. M. 2004. Trends in biological hydrogen production - a review. International Journal of Hydrogen Energy

WANG W., XIE, L., CHEN, J., LUO G., ZHOU, Q. 2011. Biohydrogen and methane production by co-digestion of cassava stillage and excess sludge under thermophilic condition. Bioresource Technology, 102, 3833-3839.

WANG, C. C.; CHANG, C. W.; CHU, C. P.; LEE, D. J.; CHANG, B.; LIAO, C. S.; TAY, J. H. 2003. Using filtrate of waste biosolids to effectively produce biohydrogen by anaerobic fermentation. Water Research, v. 37, p. 2789-2793. 
WU, S. Y.; LIN, C. N.; CHANG, J. S.; LEE, K. S.; LIN, P. J. 2002. Microbial hydrogen production with immobilized sewage sludge, Biotechnology Progress, v. 18, p. 921-926.

WU, S. Y.; LIN, C. N.; CHANG, J. S.; LEE, K. S.; LIN, P. J. 2003. Hydrogen production with immobilized sewage sludge in three-phase fluidized-bed bioreactor. Biotechnology Progress, v. 19, p. 828-832.

XIE, B., CHENG, J., ZHOU, J., SONG, W., CEN, K. 2008. Cogeneration of hydrogen and methane from glucose to improve energy conversion efficiency. International Journal of Hydrogen Energy, 33, 5006-5011.

YU, H.; ZHU, Z.; HU, W.; ZHANG, H. 2002. Hydrogen production from rice winery wastewater in an upflow anaerobic reactor by using mixed anaerobic cultures. International Journal of Hydrogen Energy, v.27, p. 1359 - 1365.

ZAIAT, M.; VIEIRA, L. G. T.; FORESTI, E. 1997. Spartial and Temporal Varations of Monitoring Performence Parameters in Horizontal-Flow Anaerobic Immobilized Sludge (HAIS) Reactor treating Synthetic Substrate. Water Research, v. 31, p. $1760-1766$.

ZHANG, Y.; SHEN, J. 2005. Effect of temperature and iron concentration on the growth and hydrogen production of mixed bacteria. International Journal of Hydrogen Energy, v. 31, p. 441 - 446. 
ZHU, H.; UEDA, S.; ASADA, Y.; MIYAKE, J. 2002. Hydrogen production as a novel process of wastewater treatment - studies on tofu wastewater with entrapped R. sphaeroides and mutagenesis. International Journal of Hydrogen Energy v.27, p. $1349-1357$.

ZWIETERING, M.H., JONGENBURGER, I., ROMBOUTS, F.M., VAN’S RIET, K. 1990. Modeling of the bacterial growth curve. Applied Environmental Microbiology, 56, 1875-1881. 